\title{
Wake Deficit Measurements on the Jess and Souza Ranches, Altamont Pass
}

\author{
R. Nierenburg \\ Altamont Energy Corp. \\ San Rafael, California
}

April 1990

Prepared under Cooperative Agreement

No. DE-FC023-85CH10253

Solar Energy Research Institute

A Division of Midwest Research Institute

1617 Cole Boulevard

Golden, Colorado 80401-3393

Prepared for the

U.S. Department of Energy

Contract No. DE-AC02-83CH10093 


\section{NOTICE}

This report was prepared as an account of work sponsored by an agency of the United States government. Neither the United States government nor any agency thereof, nor any of their employees, makes any warranty, express or implied, or assumes any legal liability or responsibility for the accuracy, completeness, or usefulness of any information, apparatus, product, or process disclosed, or represents that its use would not infringe privately owned rights. Reference herein to any specific commercial product, process, or service by trade name, trademark, manufacturer, or otherwise does not necessarily constitute or imply its endorsement, recommendation, or favoring by the United States government or any agency thereof. The views and opinions of authors expressed herein do not necessarily state or reflect those of the United States government or any agency thereof.

\section{Printed in the United States of America}

Available from:

National Technical Information Service

U.S. Department of Commerce

5285 Port Royal Road

Springfield, VA 22161

Price: Microfiche A01

Printed Copy A08

Codes are used for pricing all publications. The code is determined by the number of pages in the publication. Information pertaining to the pricing codes can be found in the current issue of the following publications which are generally available in most libraries: Energy Research Abstracts (ERA); Government Reports Announcements and Index (GRA and I); Scientific and Technical Abstract Reports (STAR); and publication NTIS-PR-360 available from NTIS at the above address. 


\section{PREFACE}

This report is the ninth in a series of documents presenting the findings of field tests under the Department of Energy's (DOE) Cooperative Field Test Program (CFTP) with the U.S. wind industry. The report provides the results of a project conducted by Altamont Energy Corporation (AEC) to measure wake deficits on the Jess and Souza Ranches in Altamont Pass, Calif. This study complements a second study conducted by AEC under the CFTP Free-Flow Variability on the Jess and Souza Ranches, Altamont Pass, (SERI/STR-217-3404), which investigated the terrain effects on wind speed at the two ranches. This research enhances and complements other DOE-funded projects to refine estimates of wind turbine array effects. This project will help to explain turbine performance variability caused by wake effects.

Three wind turbine arrays, located in the Altamont Pass east of San Francisco, Calif., were instrumented with anemometers, communications devices, and a central monitoring computer. Each array consisted of three or four rows of Nordtank 65/13-kW wind turbines with about 20 turbines in each array. Rows of turbines were switched on and off to measure the energy and speed deficits at the downwind rows. The measurements were analyzed to determine array wake effects. 


\section{ACKNOWLEDGMENTS}

A number of people contributed to the success of this project. Gary Wayne and Tom Morton of AEC conceived the idea. Morton and Brian Smith of AEC managed the project. Richard Farrell and Kevin O'Keefe of AEC assisted in arranging private sector funding. Jack Kline of Howden Wind Parks, Inc. and Robert Baker of U.S. Windpower, Inc. provided many useful suggestions for the data analysis. Dave Kresse of KENETECH Service Company helped to supervise the installation of the data collection network and conducted many of the wake deficit tests. Philip Frame, a consulting meteorologist, provided wind forecasts, conducted many of the wake deficit tests, helped to install the network, and assisted with the data processing. Walter Sass, Ken Cohn, and Mike Sacarny of Second Wind, Inc., designed and built the central monitoring computer and the communications hardware and software, which operated flawlessly. Dennis Elliott of Battelle, Pacific Northwest Laboratory (PNL), and Alan Miller, formerly with PNL, assisted in the project planning, subsequent execution, and review. Warren Bollmeier of SERI and Steve Sargent of DOE assisted in managing this project. Special thanks go to Howden Wind Parks, Inc. for releasing unpublished results of its array wake studies. 


\section{SUMMARY}

Three arrays of Nordtank 65/13-kW turbines on the Jess and Souza Ranches in Altamont Pass, Calif., were operated in a number of scenarios to quantify wake energy and speed deficits. Spacing between rows varied from 6.8 to 10.2 rotor diameters (D) but averaged about $8.5 \mathrm{D}$. Turbine spacing within rows was about $2 \mathrm{D}$. This spacing is typical of many commercial windfarm arrays.

Various test scenarios were used to measure the effect of one to three rows of turbines on a downwind test row. There were also scenarios to measure the effects of a single turbine. In addition, data were analyzed during days when winds blew parallel to the rows. In this situation, spacing between turbines was only 2 D.

Seven test scenarios were used. In the basic scenario, to test the effect of one row on another (separated by about $8.5 \mathrm{D}$ ), average wake energy deficits of approximately $12 \%$ were measured. The deficits ranged from $16 \%$ at $20 \mathrm{mph}$ down to $4 \%$ at $33 \mathrm{mph}$, and an inverse relationship between wind speed and energy deficits was established. A positive relationship was established between energy deficits and two turbine performance parameters: thrust coefficient and system coefficient of power. The energy deficits were a function of the combination of wind speed and turbine performance.

In more complex scenarios with additional, more distant upwind rows switched on, the incremental energy deficits from the second upwind row were almost $50 \%$ of the single row deficits.

A surprising finding was the large row-to-row deficits measured in 16-D tests. In spite of the greater distance between rows, the energy deficits were approximately $12 \%$, which is essentially the same as in tests with $8-D$ spacing. The inverse relationship between wind speed and energy deficits was also present. However, regression analysis of the 16-D test data showed that the deficits decreased more steeply as the wind speed increased, than they did in the 8-D test analysis.

Wind speed deficits were also examined and found to be on the order of $1 \%$ to $7 \%$. The wind speed data were collected at $35 \mathrm{ft}$ above ground level (AGL), which is about half of the hub-height. These data were collected at a level that was probably below the wake centerline, which would explain their smaller magnitude compared to the energy deficits. In some tests, power density $\left(\mathrm{W} / \mathrm{m}^{2}\right)$ deficits were calculated from the wind speed data. The power density deficits were sometimes equivalent to the energy deficits and at times were much smaller.

The magnitude of the energy deficits was inversely proportional to wind speed. Because of this relationship and the speed variability caused by the uneven terrain within rows, deficits usually varied significantly within a row. A clear pattern was present in most tests. Turbines at lower elevation sites or less exposed sites had the largest deficits within a test row. Thus, the effects of terrain are compounded by wake effects. A site with marginal exposure that has a naturally lower wind resource will suffer more severe wake deficits. 
Wake deficits in winds blowing parallel to the rows were inferred from energy production data. Turbine spacing within rows was $1.9 \mathrm{D}$. In these parallel wind cases, the energy deficits were approximately $50 \%$. As the wind direction became oblique, in winds that were $221 / 2$ (one compass point) off axis, the energy deficits were approximately $33 \%$. The energy deficits were higher at night than during the day, and they were lower in high winds than in low winds. 
TABLE OF CONTENTS

$\underline{\text { Page }}$

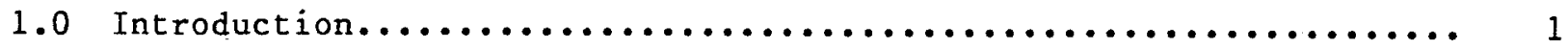

2.0 Study Methodology................................ 2

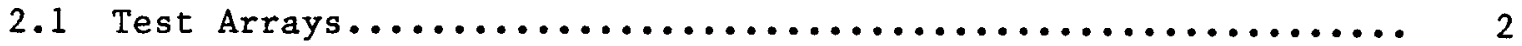

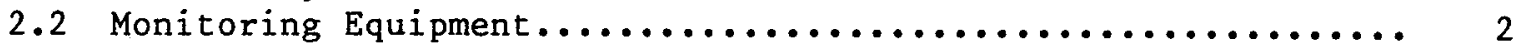

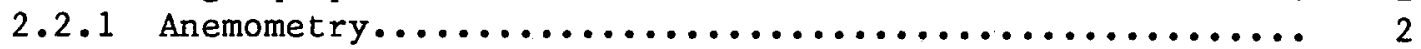

2.2.2 Central Monitoring Computer and Communicating

Turbine Monitors (TM)........................ 6

2.2 .3 Nordtank NTK $65 / 13-\mathrm{kW}$ Turbine.................... 6

2.3 Data Processing and Quality Assurance.................. 9

2.3.1 Site J08 Sensor Problems....................... 11

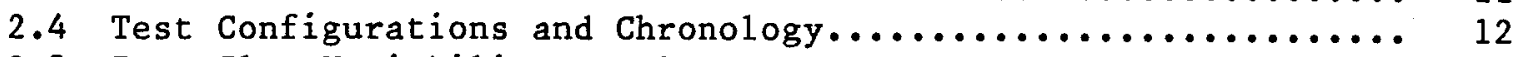

2.5 Free-Flow Variability Results...................... 15

2.5.1 Souza Ranch Correlations...................... 16

2.5 .2 Jess Ranch Correlations...................... 17

2.5 .3 Souza Ranch Ratios......................... 17

2.5 .4 Jess Ranch Ratios......................... 17

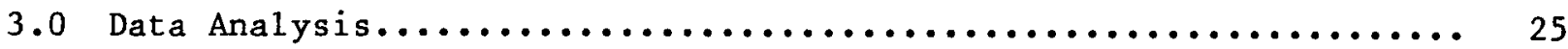

3.1 Direct Wake Effect Test.......................... 25

3.1 .1 Test 1 Analysis, Souza-C, August 7, $1987 \ldots \ldots \ldots \ldots \ldots \ldots . . \ldots 25$

3.1 .2 Test 2 Analysis, Jess-A, September 25, 1987.......... 27

3.1 .3 Test 3 Analysis, Souza-C, October $1-2,1987 \ldots \ldots \ldots \ldots \ldots . . . . .30$

3.1 .4 Souza-C Combined File....................... 34

3.1 .5 Test 5 Analysis, Jess-C, July $20,1988 \ldots \ldots \ldots \ldots \ldots \ldots \ldots . \ldots \ldots$

3.1 .6 Test 6 Analysis, Jess-C, July $21,1988 \ldots \ldots \ldots \ldots \ldots \ldots \ldots . \ldots \ldots$

3.1 .7 Jess-C Combined File...................... 41

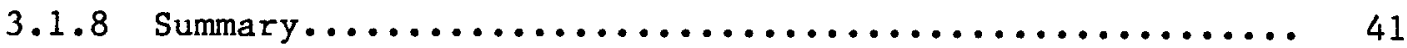

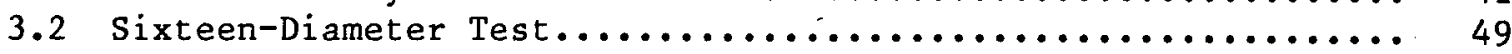

3.2 .1 Test 1 Analysis, Jess $-C$, June $14-15,1988 \ldots \ldots \ldots \ldots \ldots . . . . .49$

3.2 .2 Test 2 Analysis, Jess-C, June 16, $1988 \ldots \ldots \ldots \ldots \ldots \ldots \ldots . \ldots 1$

3.2.3 Combined File Analysis...................... 53

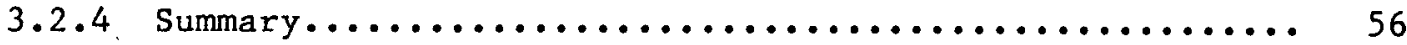

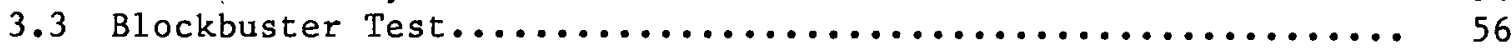

3.3 .1 Test 1 Analysis, Jess-C, September $25,1987 \ldots \ldots \ldots \ldots \ldots . . .58$

3.3 .2 Test 2 Analysis, Souza-C, October $7,1987 \ldots \ldots \ldots \ldots \ldots .63$

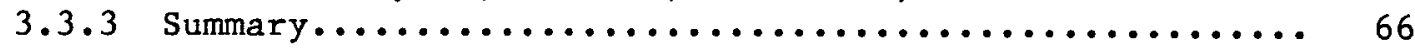

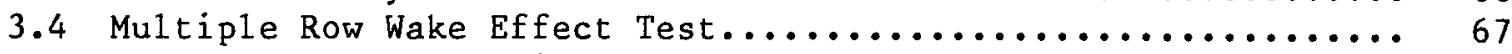

3.4.1 Test 1 Analysis, Jess-C, September 4, 1987.......... 67

3.4.2 Test 2 Analysis, Jess-A, September 10, 1987......... 72

3.4 .3 Test 3 Analysis, Souza-C, October $9,1987 \ldots \ldots \ldots \ldots \ldots \ldots 77$

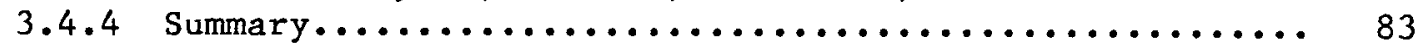

3.5 Lateral Induction Test, Jess-C, September 10, $1987 \ldots \ldots \ldots \ldots . . .65$

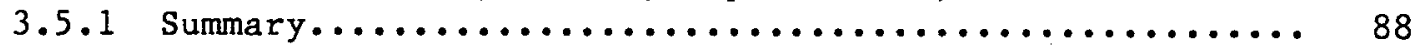


3.6 Meandering Wake Test............................. 88

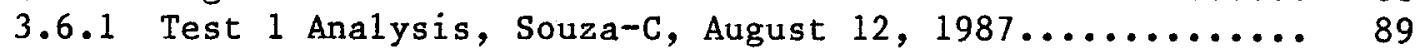

3.6.2 Test 2 Analysis, Jess-A, August 13, 1987............ 91

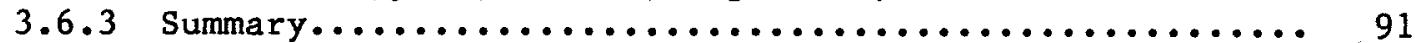

3.7 Northwest or Parallel Case......................... 91

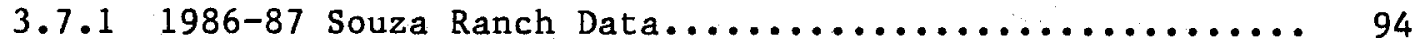

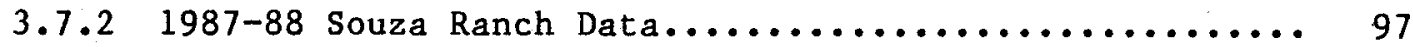

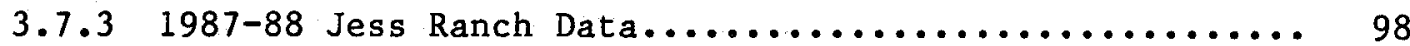

3.7 .4 Summary................................ 99

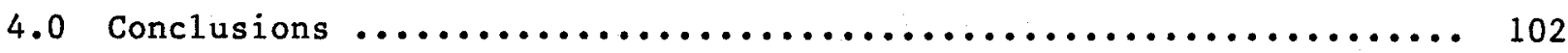

5.0 Bibliography................................... 107

Appendix A: Northwest or Parallel Case Data Analyses.............. 108 


\section{LIST OF FIGURES}

$\underline{\text { Figure }}$

$\underline{\text { Page }}$

2-1 Jess Ranch Study Areas.......................... 3

2-2 Souza Ranch Study Area........................... 4

2-3. Nordtank 65/13-kW Power Curve and Coefficient of

Power versus Wind speed........................... 7

2-3.a Thrust Coefficient vs. Wind speed................... 8

2-3.b Tip Speed Ratio vs. Coefficient of Power................ 9

2-4 Generic Test Array Configurations.................... 13

2-5 Souza Ranch Free-Flow Correlation Coefficients to S13....... 18

2-6 Jess Ranch Free-Flow Correlation Coefficients to J08........ 19

2-7 Souza Ranch Free-Flow Speed Ratios to $\$ 13(\%) \ldots \ldots \ldots \ldots \ldots$

2-8 Souza Ranch Free-Flow Theoretical Energy Ratios

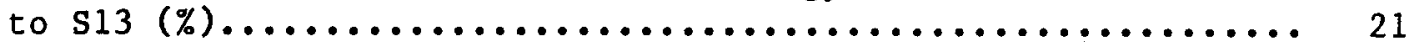

2-9 Jess Ranch Free-F1ow Speed Ratios to J08 (\%)............. 22

2-10 Jess Ranch Free-Flow Theoretical Energy Ratios to J08 (\%)..................................... 24

3-1.a Jess-A Direct Wake Effect Test -- Individual Turbine Deficits.................................. 31

3-1.b Souza-C Direct Wake Effect Tests -- Individual Turbine Deficits...................................... 37

3-1.c Jess-C Direct Wake Effect Tests -- Individual Turbine Deficits (Low-Speed Subset)....................... 45

3-1.d Wake Deficits $(\%)$ vs. Mean Wind Speed................ 47

3-1.e Wake Deficits $(\%)$ vs. Coefficient of Power............... 48

3-1.f Wake Deficits $(\%)$ vs. Thrust Coefficient................ 48

3-2.a Jess-C 16 D Wake Tests -- Individual Turbine Deficits....... 57

3-3.a Jess-C Blockbuster Test Analysis.................... 62

3-3.b Jess-C Blockbuster Test -- Individual Turbine Deficits....... 64

3-4.a Jess-C Multiple Row Wake Test -- Individual Turbine Deficits.. 71 


\section{LIST OF FIGURES (Concluded)}

Eigure

Page

3-4.b Souza-C Multiple Row Wake Test -- Individual Turbine

Deficits.................................... 82

3-4.c Two-Row Wake Deficits (\%) versus Wind Speed (mph).......... 84

3-7 Souza Ranch Northwest Case Study Rows................. 93

4-1 Wake Deficits $(\%)$ vs. Mean wind speed................ 103

4-2 Wake Deficits $(\%)$ vs. Coefficient of Power (\%)........... 104

4-3 Wake Deficits $(\%)$ vs. Thrust Coefficient............... 104 


\section{LIST OF TABLES}

Table

$\underline{\text { Page }}$

Test Array Characteristics.

Nordtank NTK 65/13 Power Curve and Other Statistics.

$2-4$ Souza-C Direct Wake Test Analysis $1 \ldots \ldots \ldots \ldots \ldots \ldots \ldots \ldots . \ldots . \ldots 26$

$3-1 \cdot b$ Jess-A Direct Wake Test Analysis................... 28 


\section{LIST OF TABLES (Continued)}

Table

$\underline{\text { Page }}$

3-5.b Effect of $1 / 2$ Row of Turbines (changing lateral spacing at upwind row from 3.8 to 1.9 D) ................... 87

3-6.a Souza-C Meandering Wake Test Analysis................. 90

3-6.b Jess-A Meandering Wake Test Analysis.................. 92

3-7.a Northwest or Parallel Case Summary: November 1986 - Apri1 1987, Souza Ranch.................................. 95

3-7.b Weighted Mean Energy Ratios for 1986-87 Souza Ranch Northwest

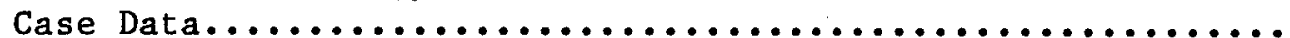

3-7.c Northwest or Parallel Case Summary: November 1987 - Apri1 1988, Souza Ranch.................................. 98

3-7.d Stratification by Wind Speed and Time of Day............. 99

3-7.e Northwest or Parallel Case Summary: November 1987 - April 1988 , Jess Ranch................................... 100

3-7.f Stratification of Jess M8 Row by Wind Speed and Time of Day.................................. 100

3-7.g Weighted Mean Energy Deficits, Souza and Jess Ranches....... 101

3-7.1a Souza E6 Row, Parallel Winds........................ 109

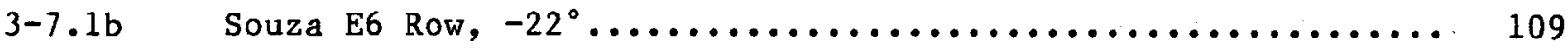

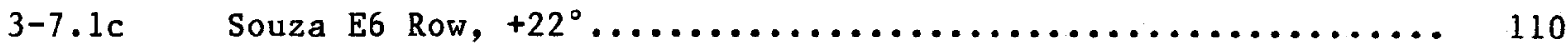

3-7.1d Souza E6 Row, Low Winds...................... 110

3-7.1e Souza E6 Row, Daylight Hours..................... 111

3-7.1f Souza E6 Row, Nighttime Hours................... 111

3-7.1g Souza E10 Row, Parallel Winds.................... 112

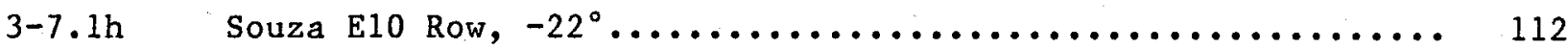

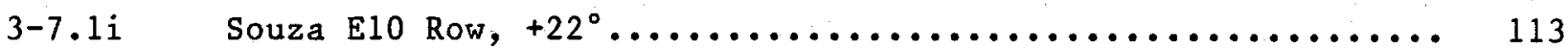

$3-7.1 \mathrm{j}$ Souza E10 Row, Low Winds......................... 113

3-7.1k Souza E10 Row, Moderate Winds..................... 114

3-7.11 Souza E10 Row, High Winds..................... 114 


\section{LIST OF TABLES (Continued)}

Table

Page

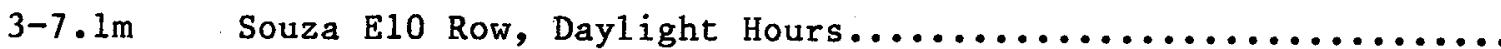

$3-7.1 n$

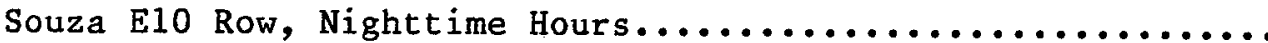

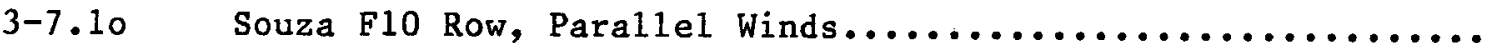

116

3-7.1p Souza F10 Row, $-22^{\circ}$

$3-7 \cdot 19$

Souza F10 Row, $+22^{\circ}$

$3-7.1$

Souza F10 Row, Low Winds.

$3-7.2 a$

Souza D6 Row, Parallel Winds.

Souza D6 Row, $-22^{\circ}$

$3-7.2 \mathrm{c}$ Souza D6 Row, $+22^{\circ}$

Souza D6 Row, Low Winds

3-7.2e Souza D6 Row, Moderate Winds

3-7.2f Souza D6 Row, High Winds

3-7.2g Souza D6 Row, Daylight Hours

3-7.2j Souza D13 Row, $-22^{\circ}$.

3-7.2k Souza D13 Row, $+22^{\circ}$

3-7.21 Souza D13 Row, Low Winds

3-7.2m Souza D13 Row, Moderate Winds.

3-7.2n Souza D13 Row, High Winds

$3-7.20$

Souza D13 Row, Day1ight Hours.

$3-7.2$

Souza D13 Row, Nighttime Hours

3-7.2q Souza E6 Row, Parallel Winds...................... 126

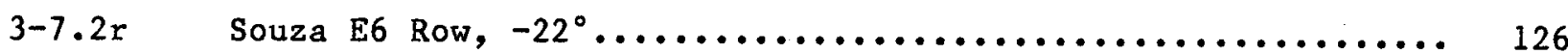

$3-7.2 \mathrm{~s}$

Souza E6 Row, $+22^{\circ}$ 
LIST OF TABLES (Continued)

Table

Page

Souza E6 Row, Low Winds

127

$3-7 \cdot 2 u$

Souza E6 Row, Moderate Winds

128

$3-7 \cdot 2$

Souza E6 Row, High Winds

128

$3-7.2$

Souza E6 Row, Daylight Hours

129

$3-7 \cdot 2 x$

Souza E6 Row, Nighttime Hours.

129

$3-7.2 y$

Souza E10 Row, Paralle

130

$3-7.2 z$

Souza E10 Row, $-22^{\circ}$.

130

3-7.2aa Souza E10 Row, $+22^{\circ}$.

131

$3-7.2 b$

Souza E10 Row, Low Winds

131

$3-7 \cdot 2 \mathrm{cc}$

Souza E10 Row, Moderate Winds

132

$3-7.2 d d$

Souza E10 Row, High Winds.

132

$3-7.2$ ee

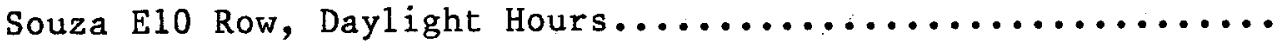

133

$3-7.2 f$

Souza E10 Row, Nighttime Hours.

133

$3-7.2 \mathrm{~g}$

Souza F9 Row, Para1lel Winds.

134

$3-7.2 \mathrm{hh}$

Souza F9 Row, $-22^{\circ}$.

134

$3-7.22 i i$

Souza F9 Row, $+22^{\circ}$.

135

3-7.2jj Souza F9 Row, Low Winds.

$3-7.2 \mathrm{kk}$

Souza F9 Row, Moderate Winds.

136

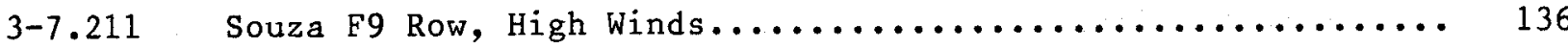

$3-7.2 \mathrm{~mm}$

Souza F9 Row, Daylight Hours

$3-7.2 n n$

Souza F9 Row, Nighttime Hours.

$3-7.3 a$

Jess L13 Row, Parallel Winds.

$3-7 \cdot 3 b$

Jess L13 Row, $-22^{\circ}$

138

$3-7 \cdot 3 c$

Jess L13 Row, $+22^{\circ}$.

139 
LIST OF TABLES (Concluded)

Table

$\underline{\text { Page }}$

3-7.3d Jess M08 Row, Parallel Winds...................... 140

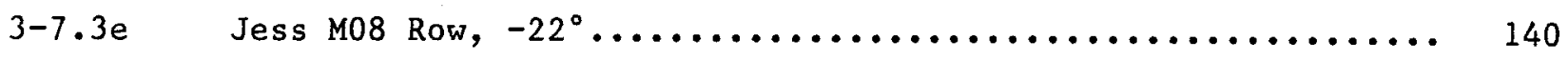

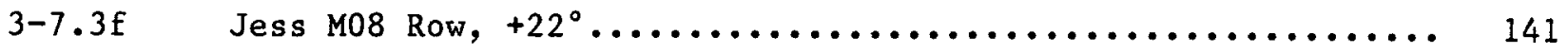

3-7.3g Jess M08 Row, Low Winds............................. 141

3-7.3h Jess M08 Row, Moderate Winds..................... 142

3-7.3i Jess M08 Row, High Winds....................... 142

3-7.3j Jess M08 Row, Daylight Hours..................... 143

3-7.3k Jess M08 Row, Nighttime Hours.................... 143

3-7.31 Jess M13 Row, Parallel Winds...................... 144

$3-7.3 \mathrm{~m} \quad$ Jess $M 13$ Row, $-22^{\circ} \ldots \ldots \ldots \ldots \ldots \ldots \ldots \ldots \ldots \ldots \ldots \ldots \ldots \ldots \ldots$

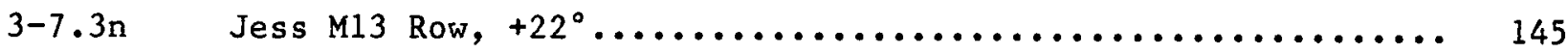




\subsection{INTRODUCTION}

Thousands of turbines have been installed in arrays in the Altamont Pass in northern California as well as the Tehachapi and San Gorgonio Passes in southern California. Windfarm developers/operators and researchers have been amazed at the variability in individual turbine energy production within these arrays. Sources of variability could include (1) individual turbine characteristics, (2) free-flow variability caused by terrain effects and (3) array wake effects. Two studies were undertaken by Altamont Energy Corporation (AEC) to address the last two items above. This report focuses on array wake deficits whereas a previous report by Nierenberg (see Bibliography) addresses the issue of free-flow variability.

Three groups of Nordtank NTK $65 / 13-\mathrm{kW}$ wind turbines were used in this study. Two groups were on the Jess Ranch in the east-central portion of Altamont Pass. These two arrays are installed on gently sloping terrain by Altamont Pass standards. The third array was located on the Souza Ranch in northern Altamont Pass. This array has moderately complex terrain.

A variety of test scenarios were undertaken to make direct measurements of the wake speed and energy deficits within these arrays. The term energy deficits is used rather than power deficits because the basic data measured and analyzed were 10-min mean energy production in $\mathrm{kWh}$ at the test turbines. It should be noted that the energy deficits were not measured over the entire spectrum of wind conditions, and the results should therefore not be construed to be annual energy deficits. The results are believed, however, to be representative energy deficits that can be expected at these sites.

In most scenarios, the downwind or back row of turbines remained on 1 ine at all times whereas various combinations of upwind turbines and turbine rows were turned on and off. The energy production in the downwind row of turbines was analyzed by comparing output during periods with no wakes (upwind rows off line) to times with expected wakes (upwind rows on line). The decrease in energy output in the downwind row is defined as the deficit. 


\section{SECTION 2.0 STUDY METHODOLOGY}

\subsection{Test Arrays}

The Jess Ranch is in the east-central portion of the Altamont Pass. It is on relatively flat terrain, by Altamont Pass standards, with elevation dropping gently to the northeast. There are two test arrays on the Jess Ranch. The Jess-A array consists of four rows of turbines with four to five turbines in each row. The Jess-C array consists of three rows of six turbines each. The Jess-B array (not shown) was not used because of mechanical availability problems. Elevations in the Jess-A array range from $570 \mathrm{ft}$ mean sea level (msl) in the northwest corner to $470 \mathrm{ft} \mathrm{msl}$ in the southeast corner. Elevations in the Jess-C array range from $520 \mathrm{ft} \mathrm{msl}$ in the western portion to $465 \mathrm{ft} \mathrm{ms} 1$ in the eastern portion. Figure 2-1 is a topographic map of the Jess Ranch test arrays. The contour intervals are five (1ighter 1 ines) and $25 \mathrm{ft}$.

The Souza Ranch test array is in the northern portion of the Altamont Pass about six miles north-northwest of the Jess Ranch. The Souza area terrain is more complex than the Jess area. The study area is on moderately rolling terrain. Elevations in the test array range from $420 \mathrm{ft} m s 1$ in the western portion to $330 \mathrm{ft} \mathrm{msl}$ in the eastern portion. Figure 2-2 is a topographic map of the Souza-C test array. The Souza-A and $-B$ arrays (not shown) were not used because of availability. The contour interval is $20 \mathrm{ft}$.

Turbines in the perimeter of the test arrays were designated as buffer turbines that would remain inoperative during testing. After a few tests were conducted, the data analysis suggested that end turbines in many rows were experiencing less deficits than turbines in the middle of a row. During discussions with project managers, it was suggested that the buffer turbines along the sides of the array might be providing an artificial "wind corridor" that could be reducing wake deficits at the end turbines in each row. It was decided that buffer turbines on the sides of rows would be operated in the same fashion as the rest of the row. The upwind buffer turbines would remain off during testing.

The Nordtank turbines are mounted on 72-ft tubular towers. The rotor diameter (D) is $52.5 \mathrm{ft}$. Spacing between turbine rows varies from array to array. Lateral spacing between turbines within rows is $100 \mathrm{ft}$ in all three arrays. This is equivalent to $1.9 \mathrm{D}$. Spacing between rows varies considerably and is plotted on Figures 2-1 and 2-2. The figures show that spacing between rows varies from $6.8 \mathrm{D}$ to $10.2 \mathrm{D}$. Mean spacing is about $8.5 \mathrm{D}$ between rows. The Jess test arrays are on flatter terrain, which might explain why the developer installed these turbines with more uniform spacing on this ranch.

Table 2-1 lists characteristics of the test arrays, which include buffer turbines, spacing, and approximate orientation of the array with respect to the upwind wind direction.

\subsection{Monitoring Equipment}

\subsubsection{Anemometry}

The reference anemometer for both test arrays on the Jess Ranch was site J08. J08 is a 50-ft tower located approximately 2 D upwind of turbine L4 in 


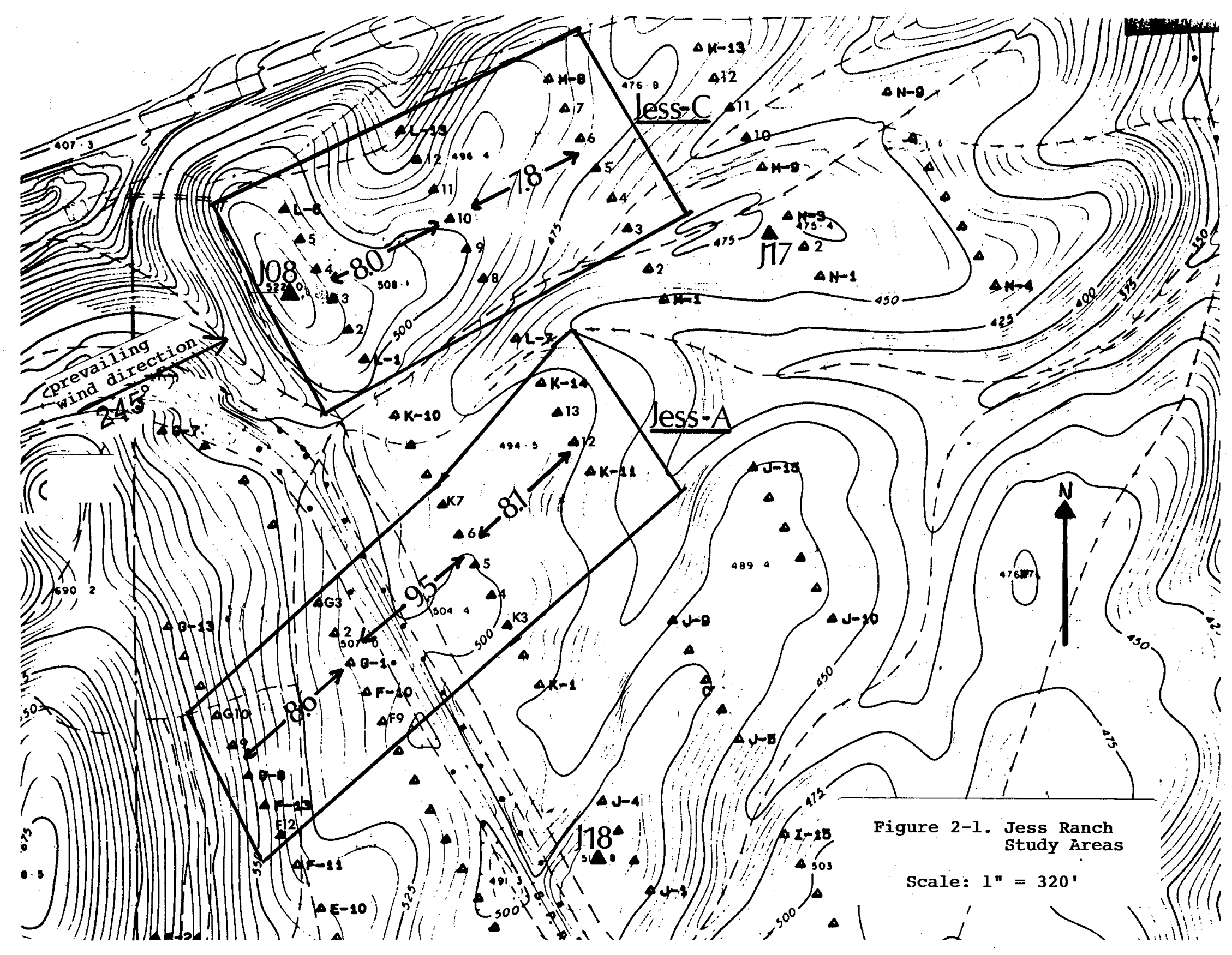

章 


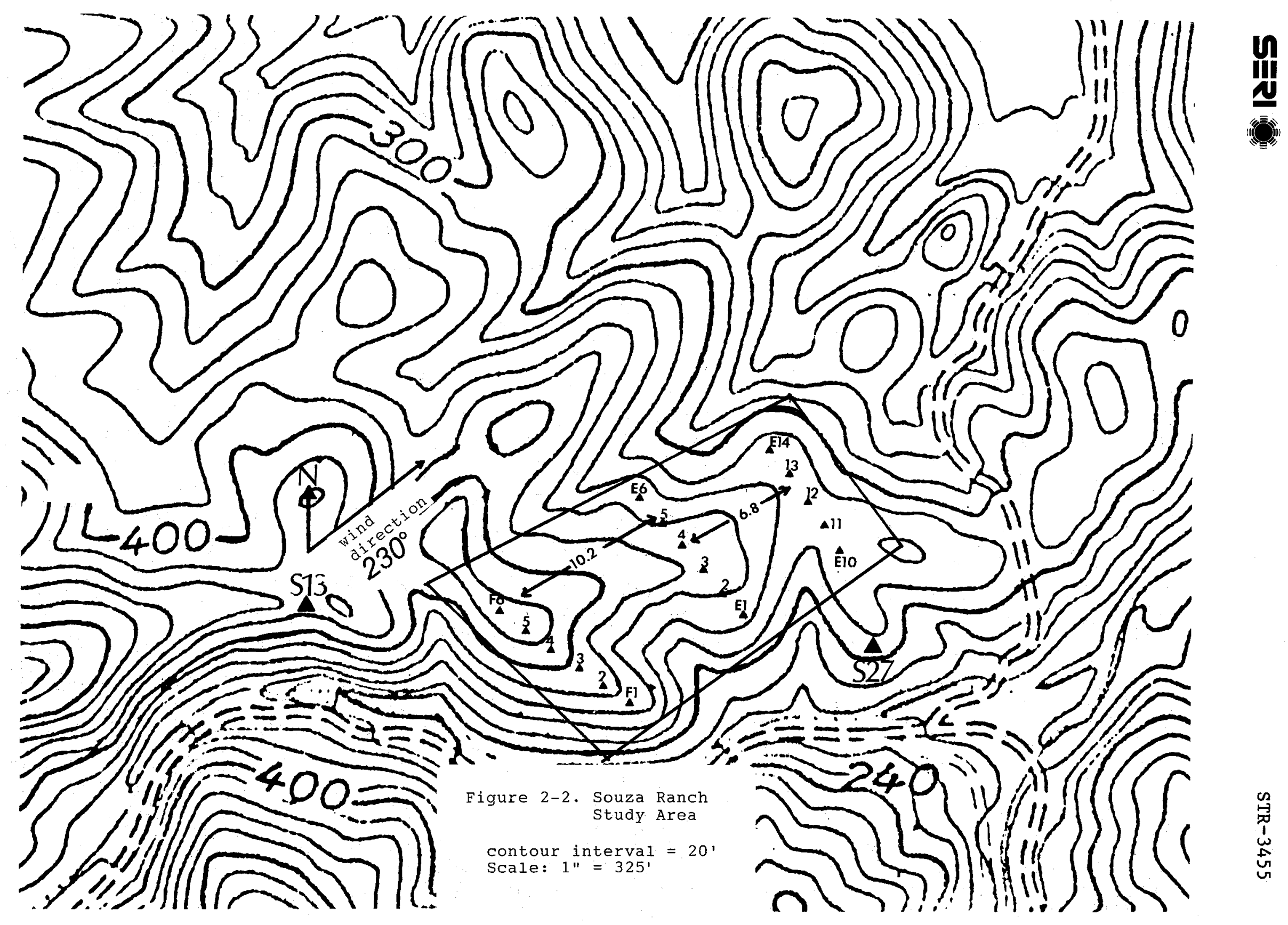


Table 2-1. Test Array Characteristics

\begin{tabular}{|c|c|c|c|c|c|c|c|c|c|c|}
\hline $\begin{array}{l}\text { Test } \\
\text { Array }\end{array}$ & & $\begin{array}{l}\text { Configura } \\
\text { (row } 1=u\end{array}$ & $\begin{array}{l}\text { atio } \\
\text { pwin }\end{array}$ & & & $\begin{array}{l}\text { Spacing } \mathrm{Be}- \\
\text { tween Rows }\end{array}$ & (RD) & & $\begin{array}{l}\text { Orient- } \\
\text { ation }\end{array}$ & $\begin{array}{l}\text { Buffer } \\
\text { Turbines }\end{array}$ \\
\hline Jess-A & $\begin{array}{l}4 \\
5 \\
5 \\
5 \\
4\end{array}$ & $\begin{array}{l}\text { rows; } \\
\text { turbines } \\
\text { " } \\
\text { " }\end{array}$ & $\begin{array}{l}\text { in } \\
" 1 \\
" 1\end{array}$ & $\begin{array}{l}\text { row } \\
" 1 \\
" 1\end{array}$ & $\begin{array}{l}1 \\
2 \\
3 \\
4\end{array}$ & $\begin{array}{l}8.6 \text { between } \\
9.5 " ~ \\
8.1 "\end{array}$ & $\begin{array}{ll}1 & \& \\
2 & \& \\
3 & \&\end{array}$ & $\begin{array}{l}2 \\
3 \\
4\end{array}$ & $230^{\circ}$ & $\begin{array}{l}\mathrm{G} 12, \mathrm{G} 4, \mathrm{~L} 7 \\
\mathrm{~K} 1, \mathrm{~K} 2, \mathrm{~K} 8, \\
\mathrm{~K} 9, \mathrm{~F} 7, \mathrm{~F} 8\end{array}$ \\
\hline $\begin{array}{l}\text { Jess -C } \\
* *\end{array}$ & 3 & rows of 6 & 5 & & & $\begin{array}{l}8.0 \text { between } \\
7.8 \text { " }\end{array}$ & $\begin{array}{ll}1 & \& \\
2 & \&\end{array}$ & $\begin{array}{l}2 \\
3\end{array}$ & $245^{\circ}$ & $\begin{array}{l}\text { K10, L6, } \\
\text { L7, L13 } \\
\text { M3 }\end{array}$ \\
\hline Souza-C & $\begin{array}{l}3 \\
6 \\
6 \\
5\end{array}$ & $\begin{array}{l}\text { rows; } \\
\text { turbines } \\
\quad " \\
\text { " }\end{array}$ & $\begin{array}{l}\text { in } \\
" 1\end{array}$ & $\begin{array}{c}\text { row } \\
" 1\end{array}$ & $\begin{array}{l}1 \\
2 \\
3\end{array}$ & $\begin{array}{c}10.2 \text { between } \\
6.8 \text { " }\end{array}$ & $\begin{array}{l}1 \& \\
2 \&\end{array}$ & $\begin{array}{l}2 \\
3\end{array}$ & $240^{\circ}$ & $\begin{array}{l}\text { F5, E1, } \\
\text { E6, E10 }\end{array}$ \\
\hline
\end{tabular}

the Jess-C array. The sensor was an R. M. Young "Wind Monitor" Propvane for the tests conducted in 1987. A problem was discovered with this sensor, which is discussed in Section 2.3.1. The sensor was replaced with a Maximum cup for the tests conducted in 1988. Two 70-ft towers with anemometers at $35 \mathrm{ft}$ and $70 \mathrm{ft}$ above ground level (agl) were installed for the free-flow study to measure vertical wind shear. These sites, J17 and J18, as well as J08, are plotted on Figure 2-1.

Because of the relatively flat terrain on the Jess Ranch, the turbines are laid out in straight rows approximately normal to the west-southwest flow. Anemometers were installed on every other turbine as part of the free-flow variability study, so that the spacing between sensors is $200 \mathrm{ft}$, crosswind, by about $450 \mathrm{ft}$ downwind. Anemometers were installed on the Nordtank turbines on $12-\mathrm{ft}$ booms at $35 \mathrm{ft}$ agl. The boom orientation was north-northwest, which is normal to the flow, so there was no tower shadow. On the Nordtank turbines, $35 \mathrm{ft}$ agl is about $11 \mathrm{ft}$ below the bottom of the rotor. The effects of the operating rotor on the anemometer were examined at one turbine. Speed ratios between this test turbine and two adjacent turbines were calculated for two periods when the test turbine was turned off and on. There were no differences in speed ratios between the test turbine and the two adjacent turbines for the two time periods. Because the ratios remained constant, it is assumed that the operating rotor had no measurable effect on the anemometer.

The reference anemometer for the Souza array was site S13, a 70-ft tower located about $2 \mathrm{D}$ upwind of turbine G5. The sensor was an R. M. Young Propvane. A second tower was also available. Site $\mathrm{S} 27$ is an 80-ft tower located 2 D crosswind (south) of turbine E7. The sensor was a Maximum cup. Both sites are plotted on Figure 2-2. 
The Souza Ranch terrain is more complex than that of Jess. On Souza, the turbine rows follow the local ridgelines to some extent. The rows are not as straight nor are they all parallel. Spacing between anemometers and sensor height is the same as on Jess. However, the boom orientation is northwesterly because the prevailing wind direction is southwesterly.

Except for the two reference towers, al1 sensors were Maximum type 40-cup anemometers. The sensors are constructed of three molded lexan cups. The transducer is an alternating current (ac) generator that produces a sine wave signal. The signal frequency is proportional to wind speed. The manufacturer specifies the accuracy to be $\pm 2.5 \%$, and the distance constant to be $9.7 \mathrm{ft}$.

The two reference towers, J08 on Jess and S13 on Souza, had R. M. Young "Wind Monitor" Model 非05103 Propvane anemometers. Wind direction was measured with a potentiometer and wind speed was measured with an ac sine wave generator. The manufacturer specifies the distance constant to be $7.4 \mathrm{ft}$ and the accuracy to be $\pm 2.0 \%$.

Approximately 60 of the Maximum cups and both propvanes were wind-tunnel tested at the University of California Davis wind tunnel. The wind tunnel test procedure called for approximately 30 samples for each sensor in wind speeds ranging from 10 to $60 \mathrm{mph}$. Almost all cups tested read $1 \%$ to $2 \%$ below tunnel speed, and the mean speed of all cups tested was $98.7 \%$ of tunnel speed. The two propvanes read about $1 \%$ above tunnel speed.

\subsubsection{Central Monitoring Computer and Communicating Turbine Monitors (CTM)}

The Second Wind, Inc., monitoring system on each ranch has two main components: (1) the central computer and (2) the CTMs. Each individual turbine has a CTM that monitors turbine status, turbine power, and wind speed and direction (if there are wind sensors installed). Turbine power is measured by two current transducers and two power transducers manufactured by Ohio Semitronics, Inc. The manufacturer specifies their accuracy to be $+1.0 \%$. The CTMs operate on a 1-s scan interval, and calculate and store 10-min averages of wind speed, as well as turbine status and 10-min integrated energy output. The CTMs are connected via cable to the central computer, which interrogates all turbines once a minute. The central computer performs many functions, but of particular importance to this study is the data archiving function. The 10-min data are stored on a Bernoulli disk drive, which permits these data to be accessed by other computers.

\subsubsection{Nordtank NTK 65/13-kW Turbine}

The Nordtank turbine is mounted on a 72-ft tubular tower and has an upwind rotor with a diameter of $52.5 \mathrm{ft}$. It has an active yaw system. The turbine has two generators, 13 and $65 \mathrm{~kW}$, and rotates at two speeds. In winds below $15 \mathrm{mph}$, the rotor rotates at $38 \mathrm{rpm}$ and is connected to the $13-\mathrm{kW}$ generator. Tip speed is approximately $70 \mathrm{mph}$. In higher winds, it switches automatically to the $65-\mathrm{kW}$ generator and rotates at $48 \mathrm{rpm}$. Tip speed is approximately $89 \mathrm{mph}$. Power regulation in high winds is controlled passively with stallregulated blades.

Figure $2-3$ is a plot of the system power curve and system coefficient of power $(C p)$ versus wind speed. Because the slope of the power curve is steepest at 


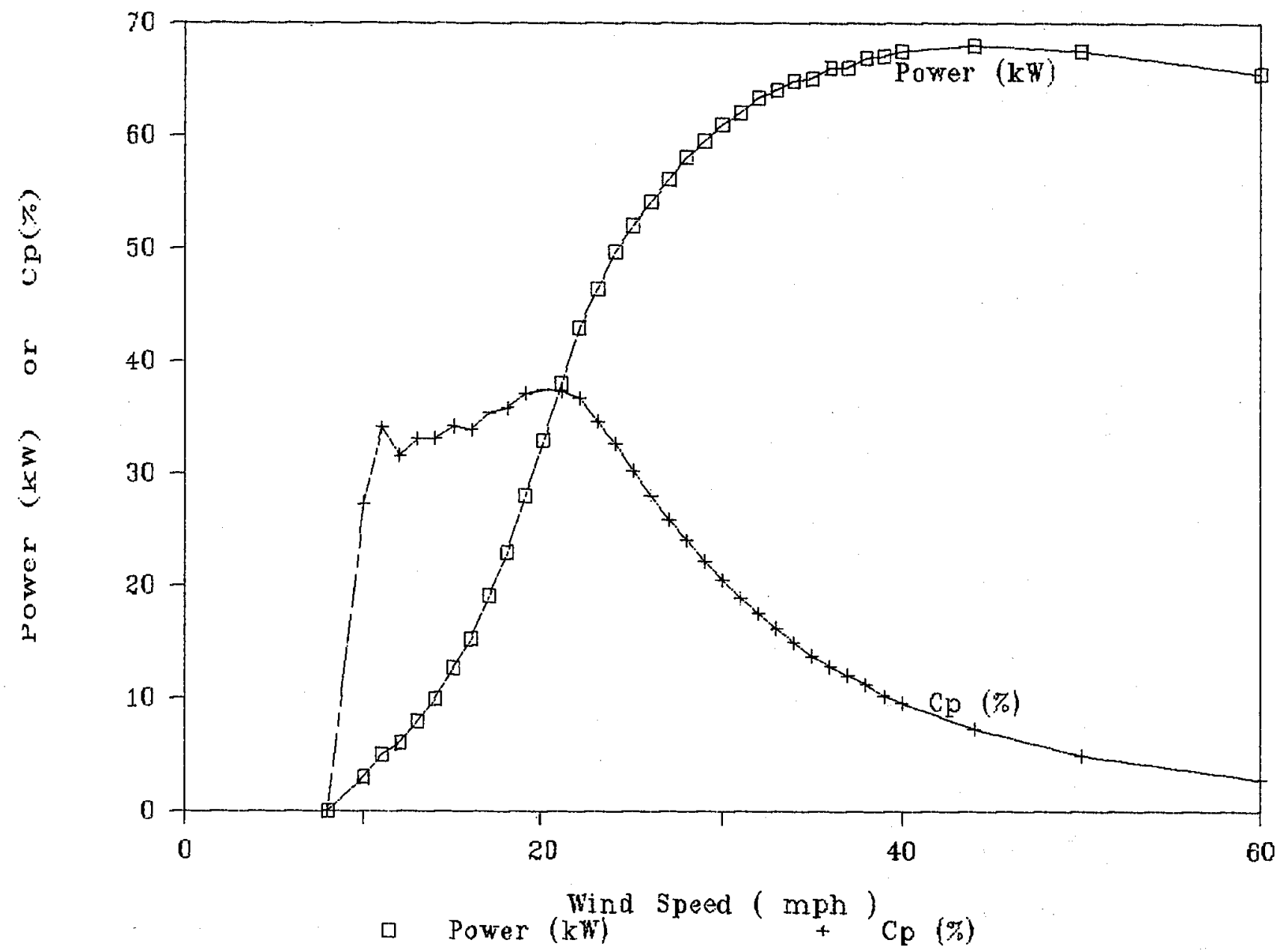

Figure 2-3. Nordtank 65/13 Power Curve and Coefficient of Power vs. Wind Speed 
about $20 \mathrm{mph}$, and one would expect maximum wake deficits to occur in this region of the curve. At about $30 \mathrm{mph}$, the slope of the power curve changes rapidly. It becomes much flatter as it approaches the "rated" speed of about $35 \mathrm{mph}$.

Because a given change in speed will produce a smaller change in power, one would expect smaller wake deficits above $30 \mathrm{mph}$.

The second curve shows that the maximum $\mathrm{Cp}$ occurs at $20 \mathrm{mph}$, where it reaches $38 \%$. A secondary maximum of $34 \%$ is found at $11 \mathrm{mph}$. This maximum occurs when the system is operating on the low-speed generator. The $C_{p}$ curve falls off very steeply above $22 \mathrm{mph}$. As mentioned in the previous paragraph, maximum deficits are expected at about $20 \mathrm{mph}$, at the maximum $\mathrm{Cp}$ and steepest part of the power curve. Deficits should decrease above this speed as the power curve flattens and $C_{p}$ decreases.

Figure 2-3.a is a plot of thrust coefficient ( $C t$ ) versus wind speed. The figure shows that in $10-$ to $30-\mathrm{mph}$ winds, the plot is nearly a straight line with a negative slope. The linear correlation coefficient between these two variables is nearly perfect at -0.997 . Because of this relationship, either variable is a suitable surrogate for the other.

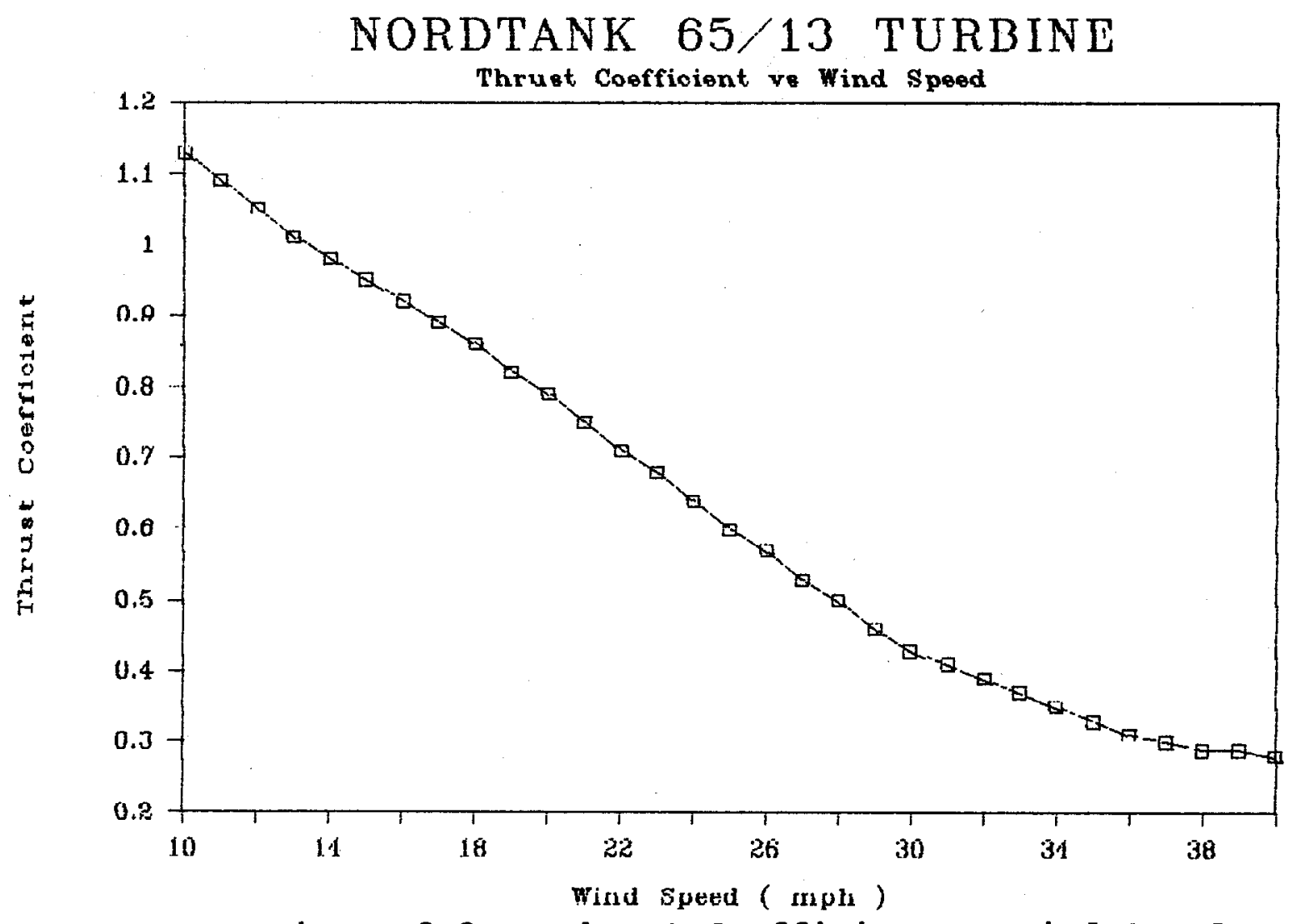

Figure 2-3.a. Thrust Coefficient vs Wind Speed 
Figure 2-3.b is a plot of tip speed ratio versus $C_{p}$. The curve shows the two peaks in $\mathrm{C}_{\mathrm{p}}$, also shown on Figure 2-3.

Table 2-2 lists the Nordtank power output, $\mathrm{Cp}, \mathrm{Ct}$, and tip speed ratio. These have been calculated for ambient air density, approximately $97 \%$ of sea level. Ct is calculated for the high-speed generator only. Therefore, the table entries of $\mathrm{Ct}$ up to $14 \mathrm{mph}$ are not absolutely correct.

\subsection{Data Processing and Quality Assurance}

The Second Wind, Inc., central monitoring computer stores the 10-min averages. These data are transferred to the office computer on a Bernoulli disk. The office computer has several programs that were used to access this data. One program is a Data Dump, which allows the user to specify a start and end time and a range of parameters. It creates a file that can be printed out or imported into a Lotus spreadsheet for review of the 10-min records.

The Data Dump program was used to extract a11 the 10-min records of speed, direction, energy, and turbine status from all test turbines and reference anemometers. This raw data file was then compared with test operator's field notes to assign each $10-\mathrm{min}$ record to the appropriate turbine configuration. Turbine configurations generally fall into three categories: upwind turbines off (i.e., no wakes), upwind turbines on (wakes), or transition periods. The 10-min records collected during the transition periods were then deleted.

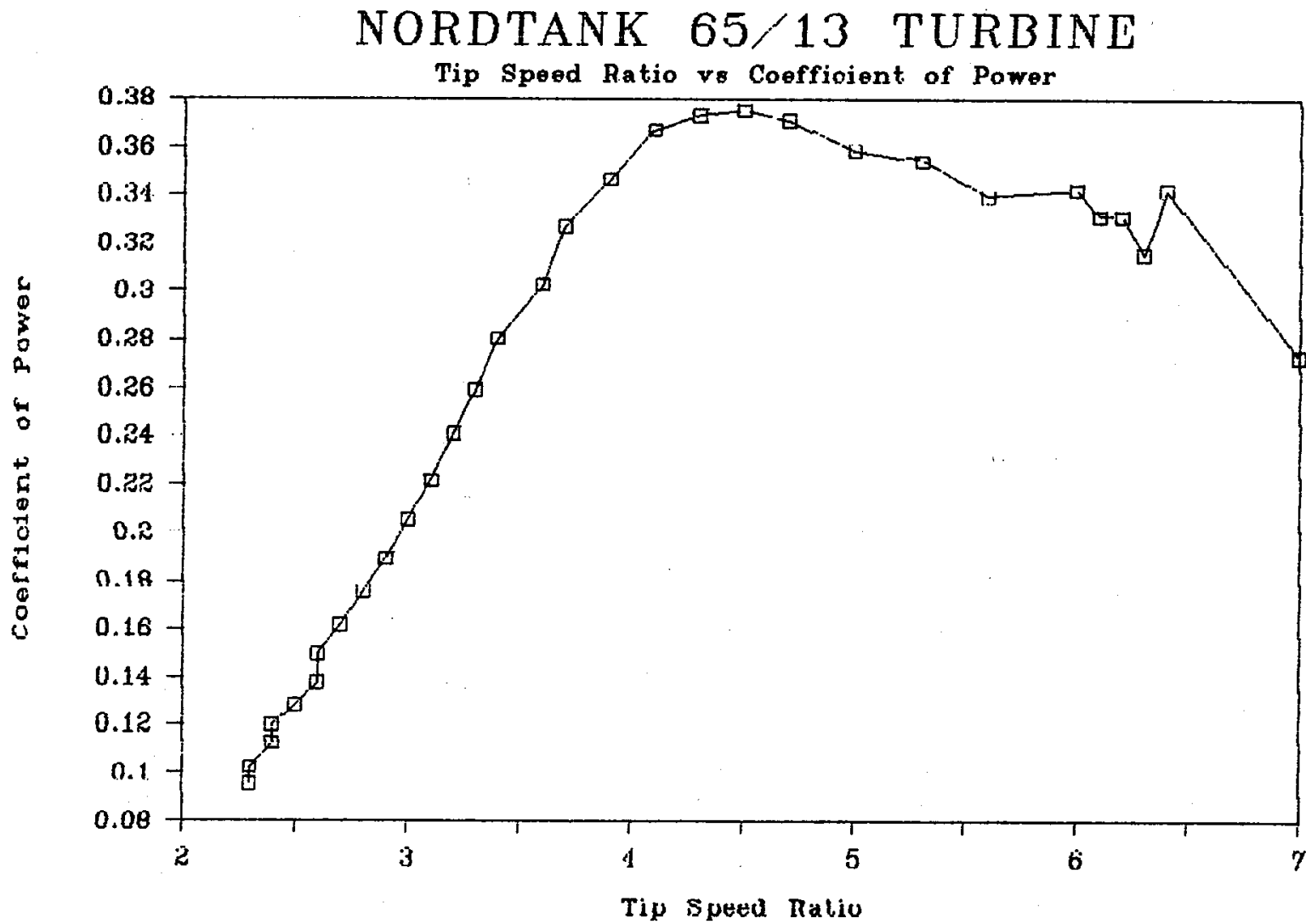

Figure 2-3.b. Tip Speed Ratio vs Coefficient of Power 
Table 2-2. Nordtank NTK 65/13 Power Curve and Other Statistics

\begin{tabular}{|c|c|c|c|c|}
\hline $\begin{array}{l}\text { Speed } \\
\text { (mph) }\end{array}$ & $\begin{array}{l}\text { Power } \\
(k W)\end{array}$ & $\mathrm{Cp}$ & $C t^{\mathrm{a}}$ & $\begin{array}{c}\text { Tip Speed } \\
\text { Ratio }\end{array}$ \\
\hline 10 & 3 & .27 & e 1.13 & 7.0 \\
\hline 11 & 5 & .34 & e 1.09 & 6.4 \\
\hline 12 & 6 & .32 & e 1.05 & 5.9 \\
\hline 13 & 8 & .33 & e 1.01 & 5.5 \\
\hline 14 & 10 & .33 & e .98 & 5.1 \\
\hline 15 & 12 & .34 & .95 & 6.0 \\
\hline 16 & 15 & .34 & .92 & 5.6 \\
\hline 17 & 19 & .35 & .89 & 5.3 \\
\hline 18 & 22 & .36 & .86 & 5.0 \\
\hline 19 & 27 & .37 & .82 & 4.7 \\
\hline 20 & 32 & .38 & .79 & 4.5 \\
\hline 21 & 37 & .37 & .75 & $4 \cdot 3$ \\
\hline 22 & 42 & .37 & .71 & 4.1 \\
\hline 23 & 45 & .35 & .68 & 3.9 \\
\hline 24 & 48 & .33 & .64 & 3.7 \\
\hline 25 & 50 & .30 & .60 & 3.6 \\
\hline 26 & 53 & .28 & .57 & 3.4 \\
\hline 27 & 54 & .26 & .53 & 3.3 \\
\hline 28 & 56 & .24 & .50 & 3.2 \\
\hline 29 & 58 & .22 & .46 & 3.1 \\
\hline 30 & 59 & .21 & .43 & 3.0 \\
\hline 31 & 60 & .19 & .41 & 2.9 \\
\hline 32 & 61 & .18 & .39 & 2.8 \\
\hline 33 & 62 & .16 & .37 & 2.7 \\
\hline 34 & 63 & .15 & .35 & 2.6 \\
\hline 35 & 63 & .14 & .33 & 2.6 \\
\hline 36 & 64 & .13 & .31 & 2.5 \\
\hline 37 & 65 & .12 & .30 & 2.4 \\
\hline 38 & 66 & .11 & .29 & 2.4 \\
\hline 39 & 67 & .10 & .29 & 2.3 \\
\hline 40 & 67 & .10 & .28 & 2.3 \\
\hline
\end{tabular}

a Calculated for high speed generator only. $\mathrm{e}=$ estimate (see text)

Al1 calculations for $97 \%$ sea-level density.

The test operators' notes included references to turbine problems that might have occurred during a test. For the entire duration of the tests, there were only ten occasions when a turbine faulted or went off line. The 10-min energy production values for these incidents were flagged because the turbine was not producing power for the entire 10 -min period. Later, during data analysis, these records were edited to normalize the energy to a full $10 \mathrm{~min}$. These records are flagged with an "e" for estimate in subsequent data listings.

In addition to these ten data records, there were $70 \mathrm{missing}$ records. These were due to turbines that were either unavailable or the production data were suspect for an entire test. These records were detected in visual scans of the data listings, and energy values during these scans were clearly invalid. 
Typically, the energy production values were off by nearly an order of magnitude from adjacent turbine values. These data were deleted and no attempt was made to estimate or $\mathrm{fill}$ in these data records. Approximately 7500 valid 10-min data records were recorded and analyzed. Therefore, overall data recovery was approximately $99 \%$.

The 10-min data files for each test were analyzed using Lotus 1-2-3 software. These files are contained in Section 3.0, the Data Analysis Section. The format for all the data listings is the same and a description follows.

The data are usually presented in two separate blocks. Each block of data contains the 10-min records for one of the test configurations such as upwind rows off or on. The data records within each block are sorted by increasing wind speed or by wind direction at the upwind reference anemometer.

Column 1 ists the start time (hour:minute) of each 10-min data record. Column 2 shows the turbine configurations, such as the number of turbines or rows of upwind turbines on or off. Column 3 lists the mean speed in mph from the reference anemometer. Column 4 lists the wind direction in degrees, at the reference anemometer. The next few columns 1 ist the 10-min energy production from the test turbines. The next column is the sum of energy production from these test turbines. In many of the tests, wind speed data were avai1able from every other turbine. These data are listed to the right of the sum of energy. Wind speed data were not analyzed in the Lateral Induction Test or the Meandering Wake Effect Test.

At the bottom of each block of data, the column means for that particular configuration have been calculated. At the bottom of the table, ratios are calculated between the mean speeds and energies for the two periods. Ideally, the speed ratios between periods at the upwind anemometer should be near unity, indicating that the two periods had similar conditions. If they are different, a second set of means may be calculated. The new set of means will eliminate the highest or lowest wind speed record (the first or last record). This "normalized" mean is compared to the other block mean to see if the two periods are closer to unity. This process reduces "bias" between the two data sets. Ideally the mean speeds at the upwind reference should be equal so there is no bias. Then, one can assume that differences in energy production are due to wakes and not temporal differences. The ratios of energy (calculated by dividing the period with turbines on by the period with them off) indicate the decrease between the periods. The energy deficit in percent can be calculated by subtracting this ratio from 100 .

Although not contained on the data 1 istings, standard deviations of the 10-min means were also calculated. The means and standard deviations were used to determine the statistical level of significance of the test results. The statistical test used was the "Student's" $t$ distribution. The test was used on all cases except the Meandering Wake Test and the Parallel Case Studies. The level of significance is given at the end of each test discussion in Section 3.0 .

\subsubsection{Site J08 Sensor Problems}

Two problems were detected with the R. M. Young sensor at site J08. This sensor was installed on September 7, 1987. Previous to this installation, 
three years of data had been collected at this site and at site J04. Site J04 is at the southwest edge of the Jess Ranch, one mile from J08. The estab1 ished speed ratio between these sites for the previous three Septembers was $98.8 \%$ ( $\mathrm{J08}=98.8 \%$ of J04). After installation of the R. M. Young sensor, this ratio jumped $2.8 \%$, to $101.6 \%$ of J04. It was felt that the J08 sensor might have a positive bias. To determine if this were true, in the field, a calibrated Maximum cup was installed at J08 at the same level, in January 1988. Three months of concurrent wind speed data were collected by these two sensors. Correlation of all concurrent wind speed data, in winds of $10 \mathrm{mph}$ or greater, showed that the R. M. Young sensor was reading $2 \%$ higher than the Maximum cup. The correlation was perfect. As a result, a11 wind speeds collected in 1987 at J08 were reduced by $2 \%$ to reflect this field calibration. Wind speed data collected at J08 in 1988 were from the Maximum cup, so no correction was necessary.

The other problem with $\mathrm{J08}$ was in orientation of the vane. It was discovered that the north point on the wind vane was oriented towards $22.5^{\circ}$ east of true north. With this orientation all wind direction data would be recorded $22.5^{\circ}$ too low. (For example, a north wind at $360^{\circ}$ would read $337.5^{\circ}$ ). It was evident from the base plate and guy wires that the mast had not turned, but had been installed incorrectly. Therefore, $22.5^{\circ}$ have been added to J08 wind direction data collected in 1987. The position of the mast was corrected prior to the 1988 testing and the R. M. Young sensor was still used to measure wind direction.

These problems were not evident at the other R. M. Young sensor installed at site $\mathrm{S} 13$ on the Souza Ranch.

\subsection{Test Configurations and Chronology}

There were seven different test configurations. Six of these involved active testing and one was passive. The test configurations are described below with the help of Figure 2-4. Figure 2-4 does not include the buffer turbines, which surround the test arrays.

The Direct Wake Effect Test was the most basic test plan to determine the wake effects of a single, row of turbines on a downwind test row. The term "test" turbines means those turbines whose energy production data are analyzed. These turbines are usually in the downwind row of the test array. In this test, the turbines in the middle row marked with "*" (see the upper left portion of Figure 2-4) are turned on and off simultaneously and the downwind row marked with "?" remains on 1ine. Energy production from the test turbines marked with "?" is analyzed. The production data are sorted into two time groups -- upwind "*" row on and upwind "*: row off. In one test, data from a third row that was about $18 \mathrm{D}$ downwind of the "*" row were analyzed to determine persistence of the wakes.

Two 10-min data samples were taken back-to-back in one mode, followed by a 10-min transition period. During the transition period, the upwind row "**" was turned on or off. Then two more 10-min samples were collected in the alternate mode. This process was repeated for 6 to $12 \mathrm{~h}$.

The Sixteen-Diameter Test was designed to determine the persistence of wake deficits at greater distances. (See the upper right portion of Figure 2-4.) 
wind Direction -.-->

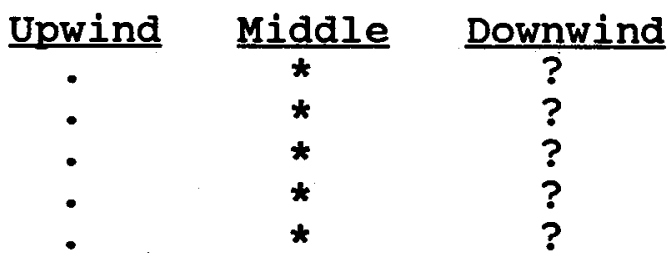

Direct Wake Effect

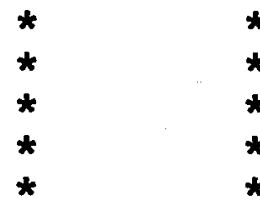

Blockbuster

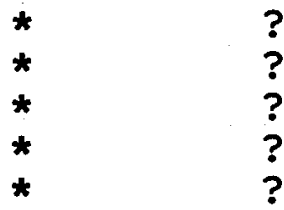

Multiple Row (1 row on)

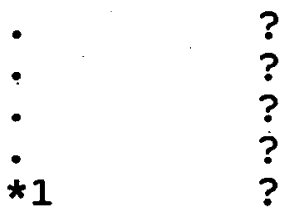

Meandering (Hour 1)
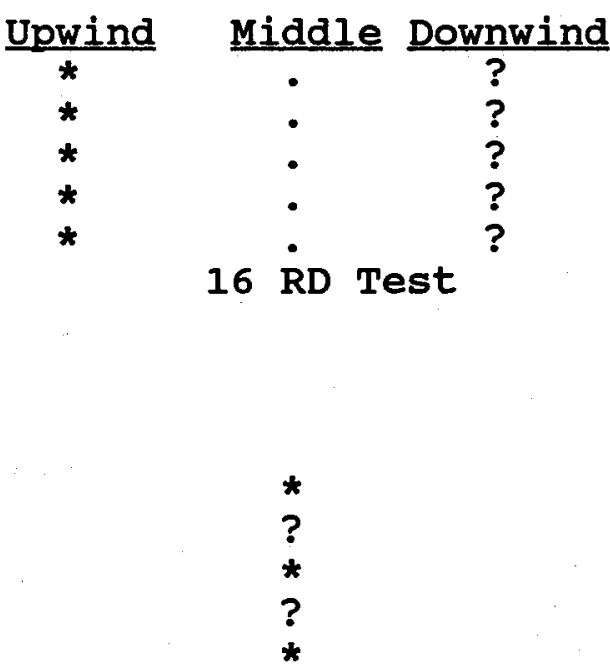

Lateral Induction
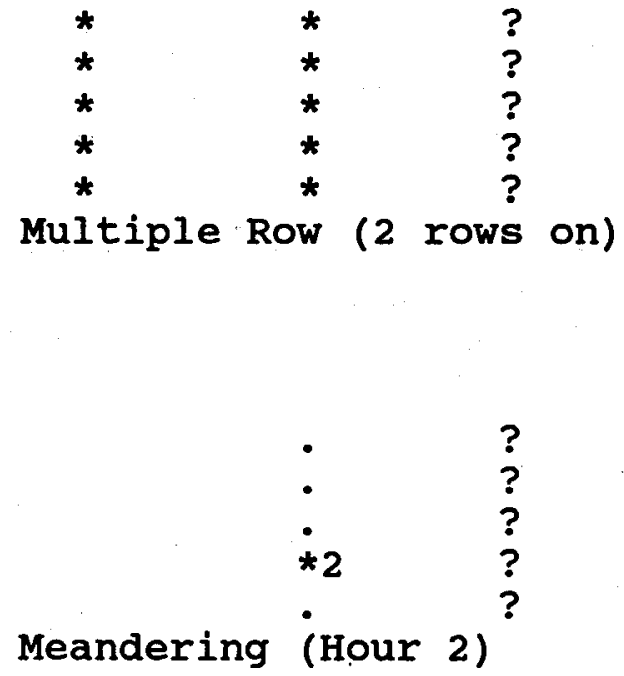

$\underline{\text { Key }}$

? = Downwind test turbines whose energy output is analyzed. These remain on-line for entire test.

* = Turbines which are switched on/off during test.

- = Turbines which are off for entire test.

Figure 2-4. Generic Test Array Configurations 
The test is a variation of the direct wake test except the spacing between rows is double. In this test, the middle row is switched off for the entire test. The downwind row "?" remains on throughout the test and is the test row. The upwind row "**" is switched on and off. Production data from the test row "?" is sorted into two groups -- "*" row on (wakes) and "*" row off. Deficits from these tests were compared to direct wake effect deficits to determine how far the deficits persist.

The Blockbuster Test was a variation of the direct wake test except that two rows of turbines are turned on and off simultaneously instead of one. This test can be thought of as an array wake effect test. (See the second from the top left portion of Figure 2-4.) Thus both upwind rows marked "*" are turned on and off, and energy production data from the test row "?", which remains on line, are analyzed. The production data is sorted into two time groups -upwind rows "*" on, and rows "*" off. In one test, data from the row downwind of the test row "?" were analyzed to determine the persistence of the wakes.

The Multiple Row Wake Effect Test is the most elaborate test plan and it produces the most data. (See the third from the top portion of Figure 2-4.) This test is designed to measure the incremental wake deficits of one, two, or three rows of upwind turbines. Row "?" is the test row and remains on line. Upwind rows "*i:" are off 1 ine and two 10 -min data samples are collected. Then one upwind row "w" is switched on line and two 10-min samples are taken. Finally, the second upwind row ":*" is switched on line and two 10-min samples are collected. The production data from the test row "?" is sorted into three groups -- upwind rows "*" off line (no wakes), one upwind row "*" on 1 ine, and two upwind rows "\%" on line. The data from the middle row are analyzed as we11. When this row is on line, its production data are sorted into two groups -- upwind row "**" on and upwind row " $*$ " of $f$. Thus the middle row data are the same as a direct wake effect case.

The Lateral Induction Test was designed to measure the effects (enhancement) that might occur at an individual turbine as adjacent turbines are switched on and off. The theory is that the wind, to some extent, will follow the path of least resistance, which is between turbines. A venturi effect could be occurring as a result. As the gaps between turbines within a row are closed, production could be enhanced. This could occur because the wind blowing around the rotor disk of one turbine would be forced through the adjacent turbine's rotor. This is generally referred to as the "windwall" effect by the developers. In this scenario, only one row is used. (See the right, second from the top portion of Figure 2-4.) Turbines "* " are switched on and off. The energy production at "?" turbines is compared between the two periods. If there are lateral induction effects, "?" turbine output will increase during the periods when "*" are on. line. In this study, energy production was analyzed at the next downwind row as well, to determine the wake effects downwind of one-half row of turbines.

The Meandering Wake Test was designed to measure the effects of a single turbine on a downwind row of turbines. In this test, row "?" turbines remain on line and "*1" is switched on. One hour later, "*1" is turned off and "*2" is switched on. In Figure 2-4, only "*1" and "*2" are illustrated at the bottom of the figure. In another hour, "*2" is switched off and "*3" is switched on. This continues until "*5" is reached. The data are analyzed from the test row "?" by sorting it into 1-h periods. The wake deficit should 
progress up the test "?" row in hourly steps, if the wind direction remains constant. The individual 10-min records were also examined. The mean wind direction for each period was used to determine wake trajectory. Energy production from the turbines in the expected wake path was compared to the other turbines in the test row, to see if production dropped. The analysis is more qualitative than quantitative.

The Northwest or Parallel Case is a passive test. During the winter and spring seasons, north-northwest winds, which are parallel to the rows, occur intermittently. The 10-min data from two entire six-month periods were analyzed. Data were screened by wind direction; only records with this type of flow were analyzed. In this scenario (not illustrated), the northernmost turbine in each row is the upwind reference turbine. Energy production from the remaining turbines in each row is compared to the reference turbine in each row. In this scenario, turbines are spaced at $1.9 \mathrm{D}$.

Additional analysis was done by screening further. Data were screened for

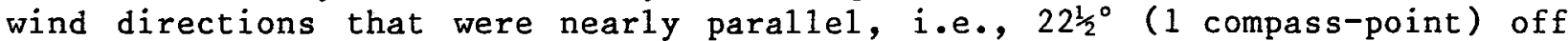
axis. The production data were analyzed in the same manner as above, except the winds were nearly parallel instead of parallel. Screening data by wind speed and time of day was also done. In all these cases, energy ratios between the upwind turbine and the downwind turbines in each row were calculated. On flat terrain, with no wake deficits, one would expect energy ratios of unity. If the energy ratios are less than unity, then there is an energy deficit. Unfortunately, the terrain is not flat, which complicates matters. The measured energy ratios are a result of terrain and wake influences.

Table 2-4 1 ists the dates, locations, test duration and the section in this report of all the active tests described above.

\subsection{Free-Flow Variability Results}

The free-flow data were collected to determine terrain effects on wind speeds on the Jess and Souza Ranches. The term free flow is used because all turbines were shut down for these tests, ensuring no local wake effects. The data and analyses are contained in the report Free-Flow Variability on the Jess and Souza Ranches, Altamont Pass (see Bibliography). Some brief excerpts from that report are contained in this section.

The results of the free-flow report are useful for interpreting the wake deficit results. The subsequent speed and energy ratio maps are of particular interest. Because the terrain is complex on these ranches, there are variations in the ambient flow at the test turbines. Turbines at the best exposed sites had higher speed and energy ratios than other turbines in a given test row. In Section 3.0, it will be shown that there was a strong inverse relationship between wind speed and energy deficits. Because of the variation in exposure in the test rows and the inverse relationship, there were large variations in the deficits within the test rows. The best exposed sites in each row typically had the highest energy output (highest winds) and the smallest deficits. Sites with poor exposure had lower output and higher deficits. No attempt has been made to normalize the individual turbine deficits for terrain (speed-up) effects. This would be a difficult process, with no prescribed methodology or purpose. The wake test results present the individual deficits, as well as the row average. 
Table 2-4. Test Dates and Locations

\begin{tabular}{|c|c|c|c|c|}
\hline $\begin{array}{l}\text { Test } \\
\text { Type }\end{array}$ & Date & Array & $\begin{array}{l}\text { Report } \\
\text { Section }\end{array}$ & $\begin{array}{l}\text { Test } \\
\text { Duration }\end{array}$ \\
\hline Direct Wake & $\begin{array}{l}\text { Aug. } 7,1987 \\
\text { Sep. } 25,1987 \\
\text { Oct. } 1-2,1987 \\
\text { July } 18,1988 \\
\text { July 20, } 1988 \\
\text { July } 21,1988\end{array}$ & $\begin{array}{l}\text { Souza-C } \\
\text { Jess-A } \\
\text { Souza-C } \\
\text { Jess-C } \\
\text { Jess-C } \\
\text { Jess-C }\end{array}$ & $\begin{array}{l}3.1 .1 \\
3.1 .2 \\
3.1 .3 \\
3.1 .7 \\
3.1 .5 \\
3.1 .6\end{array}$ & $\begin{aligned} 8 & \text { hours } \\
10 & \text { hours } \\
11 & \text { hours } \\
4 & \text { hours } \\
10 & \text { hours } \\
6 & \text { hours }\end{aligned}$ \\
\hline Sixteen RD & $\begin{array}{l}\text { June } 14-15,1988 \\
\text { June } 16,1988\end{array}$ & $\begin{array}{l}\text { Jess }-C \\
\text { Jes } \text {-C }^{-C}\end{array}$ & $\begin{array}{l}3.2 .1 \\
3.2 .2\end{array}$ & $\begin{aligned} & 10 \text { hours } \\
& 8 \text { hours }\end{aligned}$ \\
\hline Blockbuster & $\begin{array}{l}\text { Sep. } 25,1987 \\
\text { Oct. } 7,1987\end{array}$ & $\begin{array}{l}\text { Jess-C } \\
\text { Souza-C }\end{array}$ & $\begin{array}{l}3.3 .1 \\
3.3 .2\end{array}$ & $\begin{array}{l}10 \text { hours } \\
10 \frac{1}{2} \text { hours }\end{array}$ \\
\hline Multiple Row & $\begin{array}{l}\text { Sep. 4, } 1987 \\
\text { Sep 10, } 1987 \\
\text { Oct. 9, } 1987\end{array}$ & $\begin{array}{l}\text { Jess-C } \\
\text { Jess-A } \\
\text { Souza-C }\end{array}$ & $\begin{array}{l}3.4 .1 \\
3.4 .2 \\
3.4 .3\end{array}$ & $\begin{array}{l}8 \text { hours } \\
10 \text { hours } \\
12 \text { hours }\end{array}$ \\
\hline $\begin{array}{l}\text { Lateral } \\
\text { Induction }\end{array}$ & Sep. 10,1987 & Jess-C & 3.5 & 4 hours \\
\hline $\begin{array}{l}\text { Meandering } \\
\text { Wake }\end{array}$ & $\begin{array}{l}\text { Aug. } 12,1987 \\
\text { Aug. } 13,1987\end{array}$ & $\begin{array}{l}\text { Souza-C } \\
\text { Jess-A }\end{array}$ & $\begin{array}{l}3.6 .1 \\
3.6 .2\end{array}$ & $\begin{array}{l}5 \text { hours } \\
5 \text { hours }\end{array}$ \\
\hline
\end{tabular}

free-flow data collection took place on the Souza Ranch from September 10, 1987 through September 14, 1987. The duration of the data collection phase was $94 \mathrm{~h}$. Data collection on the Jess Ranch took place in two periods: October 1 through October 3, 1987, and October 7 through October 10, 1987. The duration of the Jess data collection phase was $102 \mathrm{~h}$. Although data collection took place in October on the Jess Ranch, the meteorological conditions were typical of summer.

\subsubsection{Souza Ranch Correlations}

The first step in the free-flow data analysis was the correlation of all hourly wind speed data to the reference towers. Correlation is defined as the degree of relationship between variables. The correlation coefficient is a dimensionless number that varies from -1 to +1 . A positive correlation means that variable $y$ tends to increase as variable $x$ increases. A negative or inverse correlation means that variable $y$ tends to decrease as variable $x$ increases. The correlation coefficient should not be confused with a ratio. Two variables or sites could have a high degree of correlation, close to 1.0 , 
but have a ratio very different from unity. Figure $2-5$ is a plot of all the linear correlation coefficients $(r)$ to reference site s13. The figure shows that the turbines in the test array were all highly correlated to site S13. The correlation coefficients ranged from 0.94 to 0.99 . Turbines at the north end of each row had the highest correlations. The correlation data are important because they show how representative the reference anemometer data are to the study arrays.

\subsubsection{Jess Ranch Correlations}

Figure 2-6 is a plot of the correlation coefficients to site J08 for the Jess Ranch test arrays. Note that only the end turbines in each row are labeled on this figure and on Figures 2-9 and 2-10. A11 turbines are labeled on Figure 2-1. Figure 2-6 shows that the correlations on Jess decreased at sites immediately downwind of the 678-ft hill near the Jess-A array. The turbines in the Jess-C array were highly correlated to J08 with a range of 0.98 to 1.0. The turbines in the Jess-A array had correlation coefficients that were fair to good. The range was from 0.76 to 0.96 . The last two rows of this array, where most of the wake analysis was done, had higher correlations than the first two rows. The coefficients in the back two rows ranged from 0.84 to 0.96 .

\subsubsection{Souza Ranch Ratios}

Figure $2-7$ is a plot of the speed ratios to $\mathrm{S} 13$ for the free-flow data period. The wind speeds were quite uniform. Almost all the site ratios were within a range of $90 \%-110 \%$ of $\mathrm{S} 13$. There is a high wind area at turbines F2-F6. Speed ratios decrease at successive downwind rows. It is especially important to note the ratios at E10, E12, and E14, where almost all the Souza wake data were collected. Note the low ratio at turbine E14. This turbine usually had the highest wake deficit in this row. Deficits at turbine E10 were usually much lower.

Figure $2-8$ is a plot of the theoretical energy ratios to $\mathrm{S} 13$. The pattern is the same as Figure 2-7. No vertical shear adjustments were made to correct the $35-\mathrm{ft}$ data to hub-height $(72 \mathrm{ft})$. Site $\mathrm{S} 13$ vertical shear exponent (alpha) was about one-half the "normal" value of 0.14 (for flat terrain) and S27 shear was about zero. At sites that are not on the tops of well-exposed ridges, shear values may be close to 0.14 . This is probably true at many of the "E" sites, which are on terrain that slopes gently down behind a ridge. Therefore, the energy ratios on Figure 2-8 may be artificially low at these sites. However, trying to estimate wind shear at individual sites is difficult. The resulting errors could be larger than if the data are simply presented as is.

\subsubsection{Jess Ranch Ratios}

Figure $2-9$ is a plot of the speed ratios to J08 for the free-flow data period. Note that all ratios are less than $100 \%$. This is due to site J08's excellent exposure. J08 is situated on a bluff that juts into the large canyon that Interstate 580 runs through. J08 is exposed to this channel, which is oriented parallel to the west-southwest flow. Ratios within rows in the Jess-C array are highest at the north end and lowest in the south end. Much of the wake data were collected at turbines $M 4$ through $M 8$ in this 


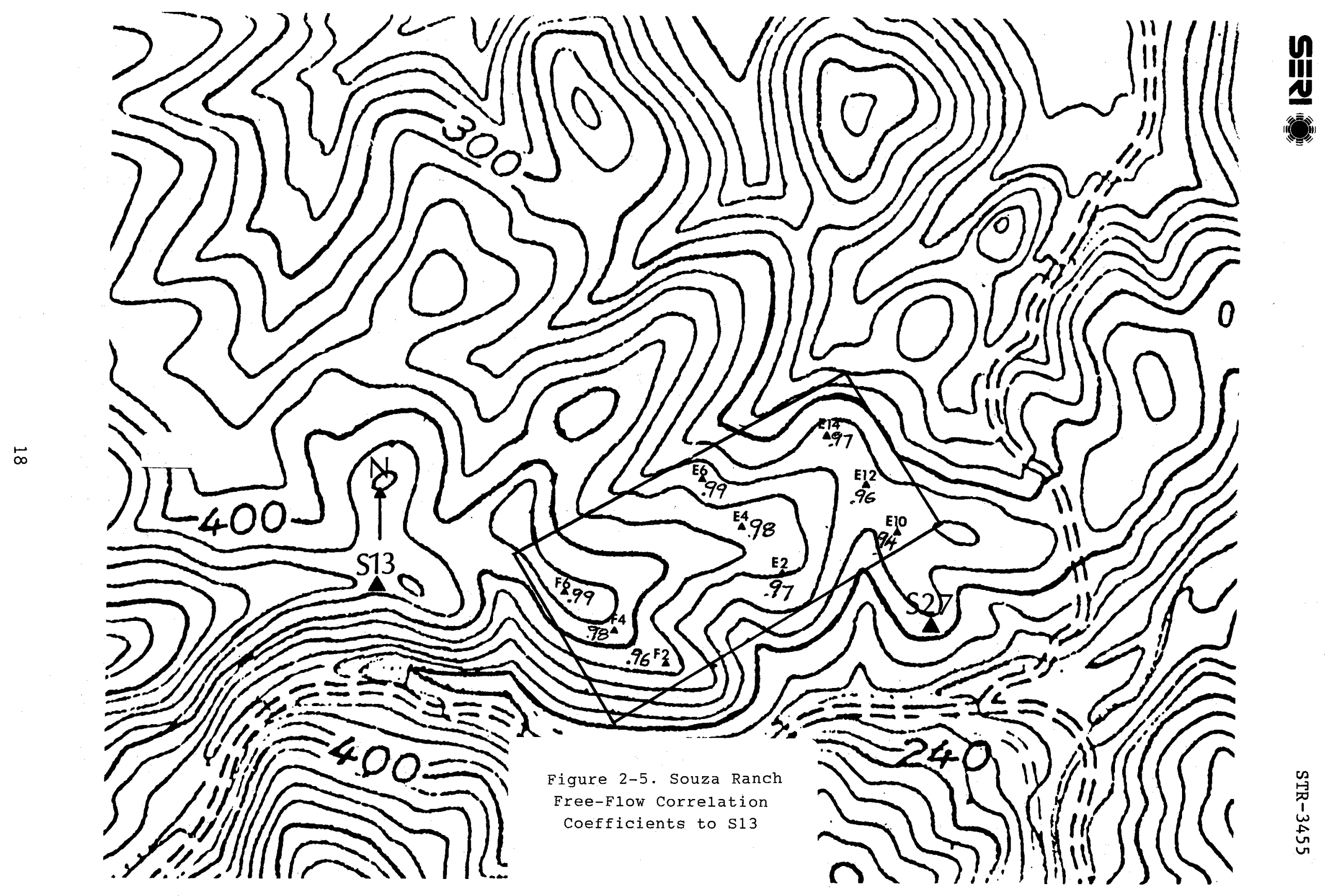




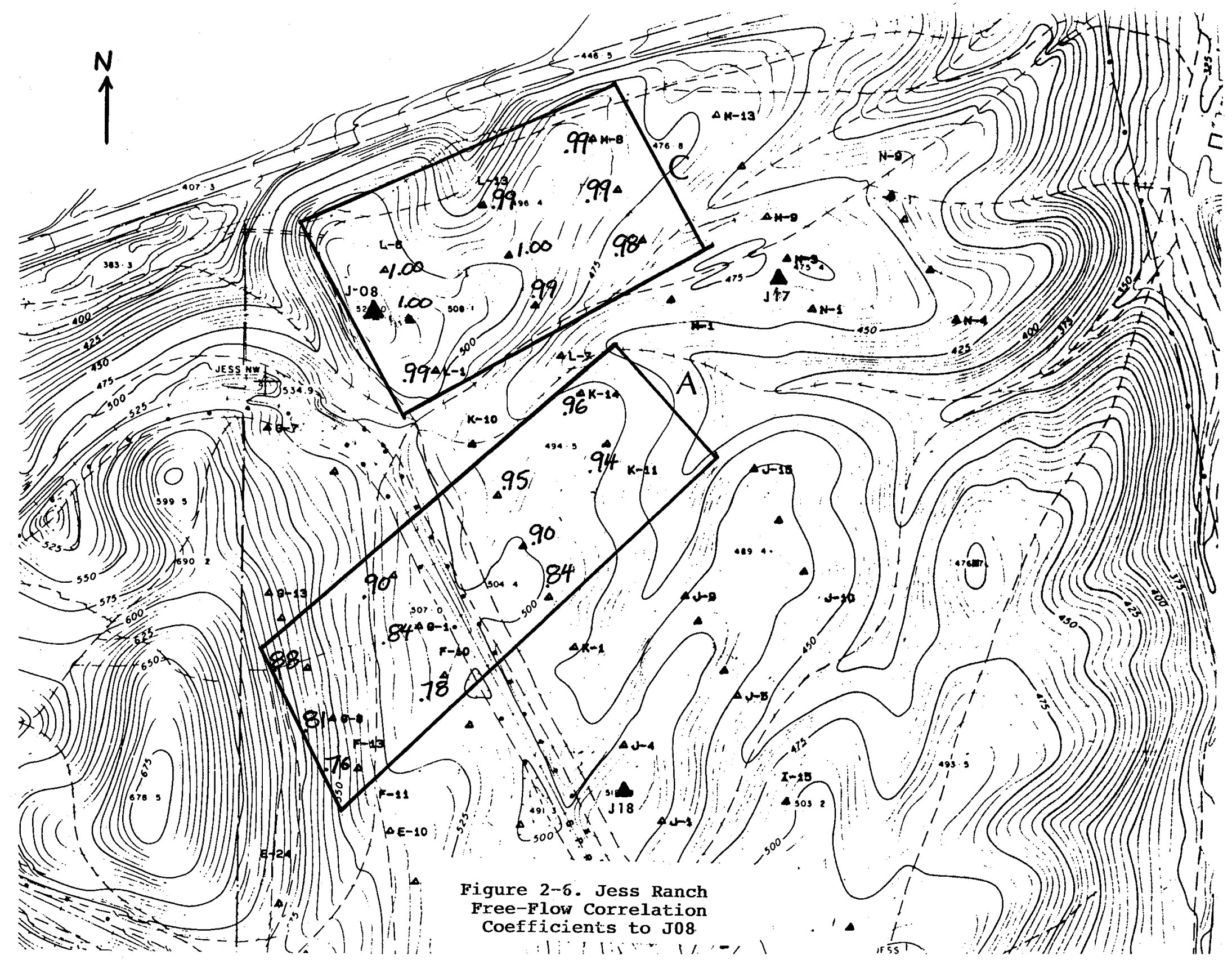




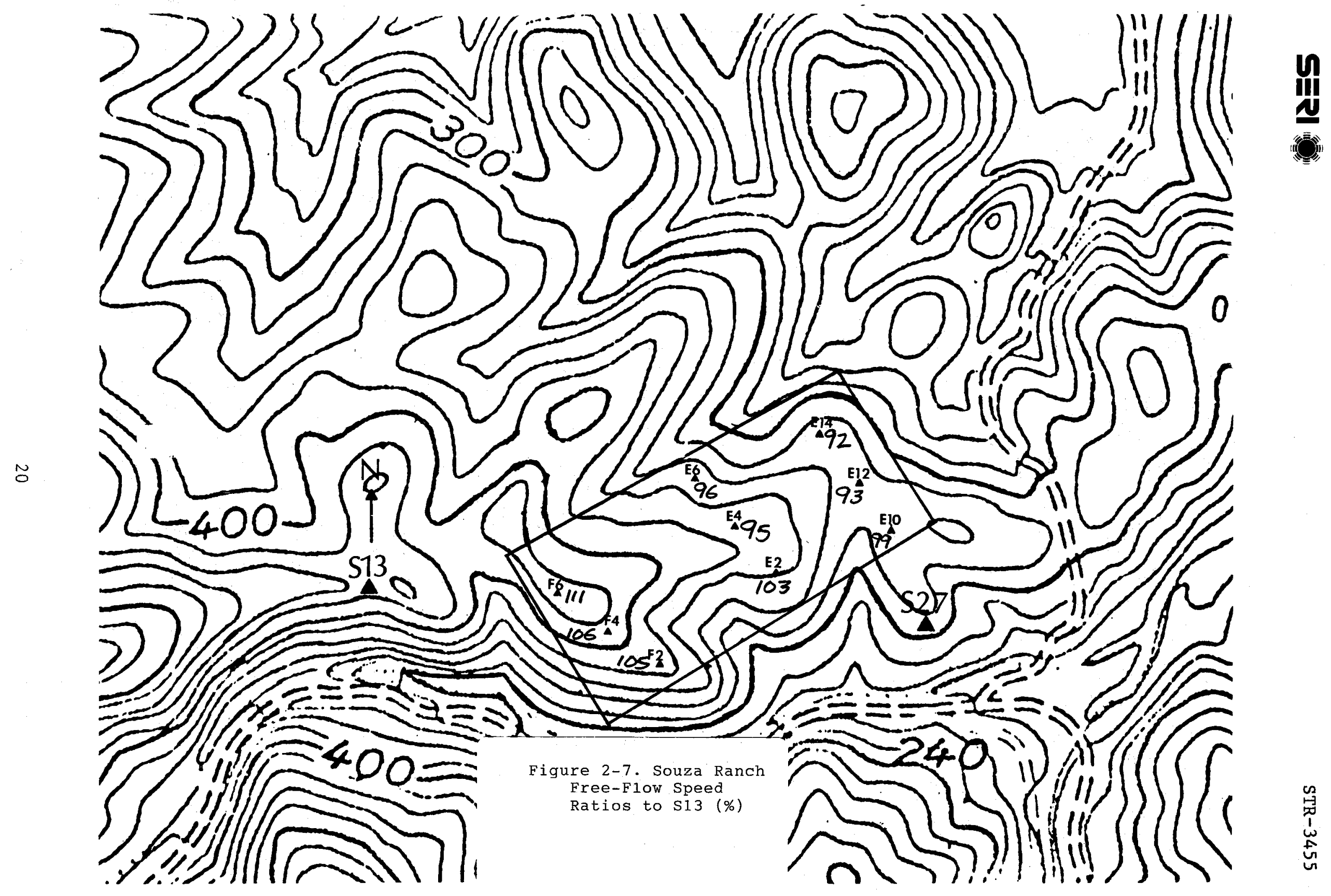




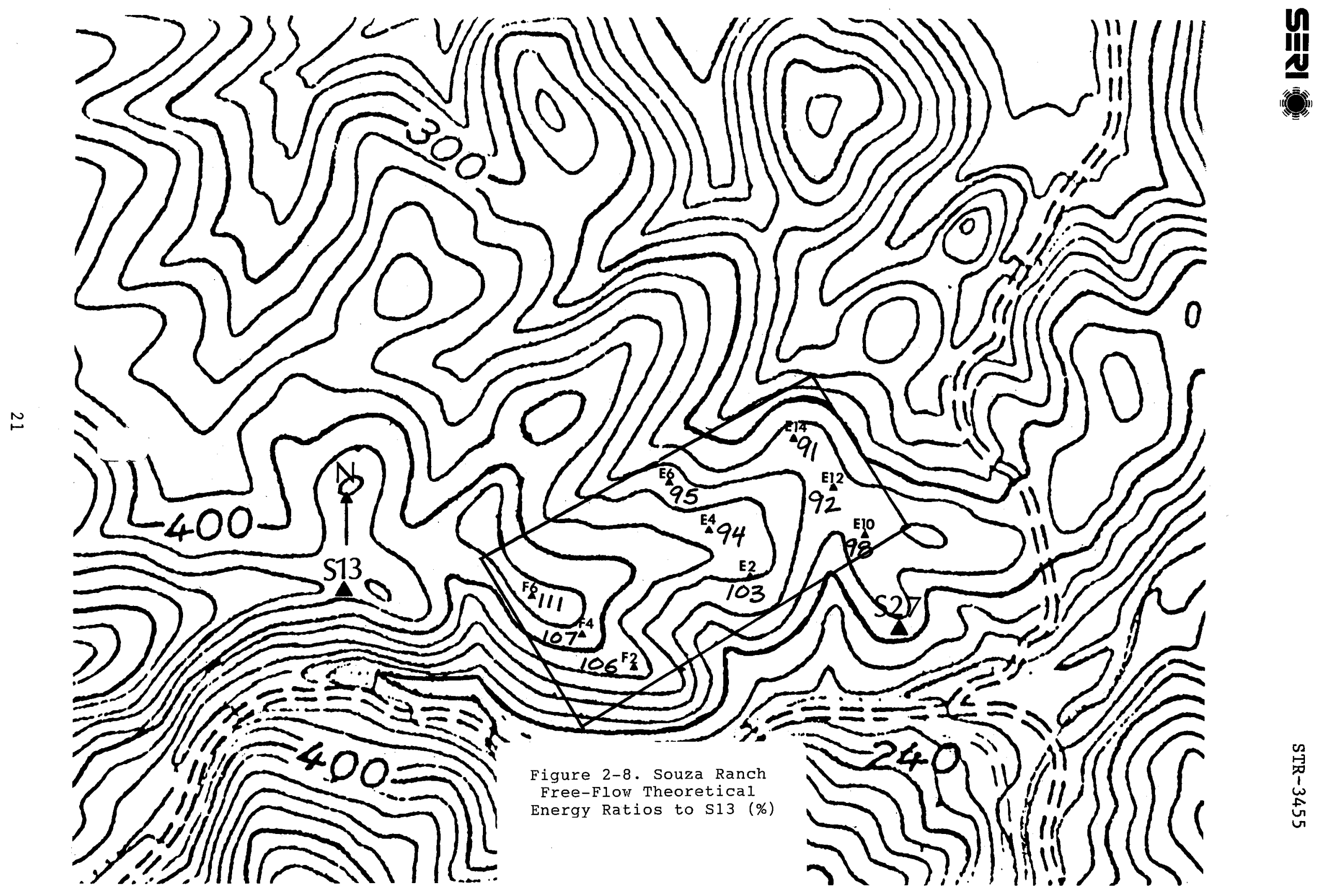




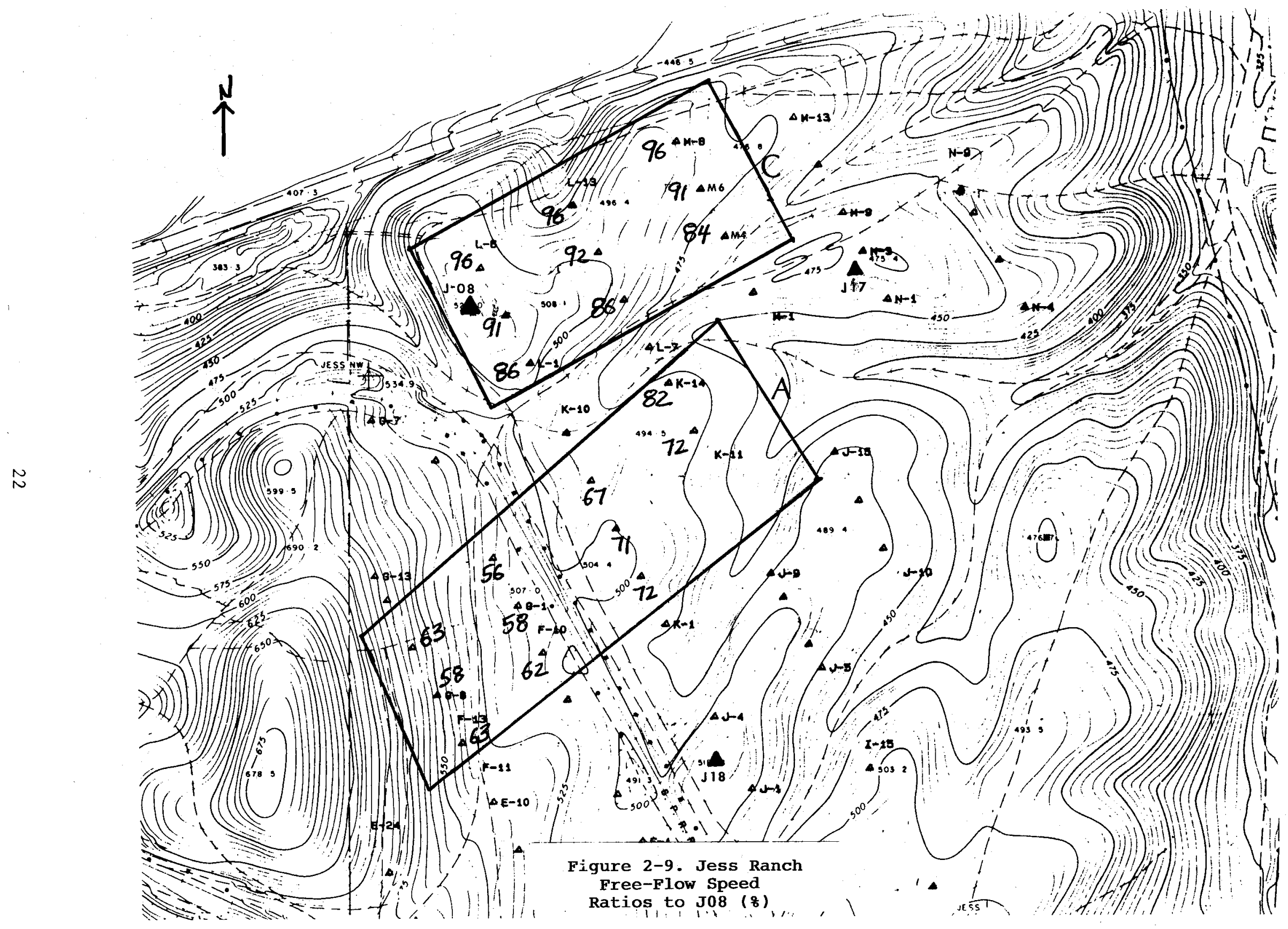

墨 
array. Turbine M8 at the north end of the row is on the highest terrain and had the highest ratios. This turbine almost always had the lowest deficits within the row. Turbine M4, at the other end, is on lower terrain, had lower speed and energy ratios and usually had the highest deficits.

It is interesting to note that the range of ratios on Jess is considerably larger than on Souza. The Jess test arrays are larger than Souza, but because of the flatter terrain, more homogeneity was expected on Jess. Note that ratios in Jess-A are considerably lower than in Jess-C. This is probably caused by shadowing of the Jess-A group by the 678-ft hill immediately upwind.

Figure 2-10 is a plot of the theoretical energy ratios to J08. Note that all sites except $J 08$ have been normalized to hub-height $(72 \mathrm{ft}$ ) using a vertical wind shear exponent of 0.10 . Sites J17 and J18 had shear exponents of about 0.10. These sites have exposure that is representative of many of the sites on Jess. They are in fairly flat areas and not on highly exposed knolls like J08. Use of an alpha of 0.10 is a good compromise. Some sites like turbines L3 and L5 near J08 probably have less positive shear because of their similar exposure to J08. Thus their theoretical energy production may be biased positively. Other sites downwind of a hill, such as G1, G3, and G8, probably have higher shear than 0.10. Thus, they may be negatively biased. As mentioned earlier, estimating individual sites' vertical shear is difficult and so the reader is cautioned that individual energy ratios on Figure 2-10 could be in error by as much as $10 \%$. Figure $2-10$ shows a similar pattern to Figure 2-9 except that there is a wider range of ratios. 


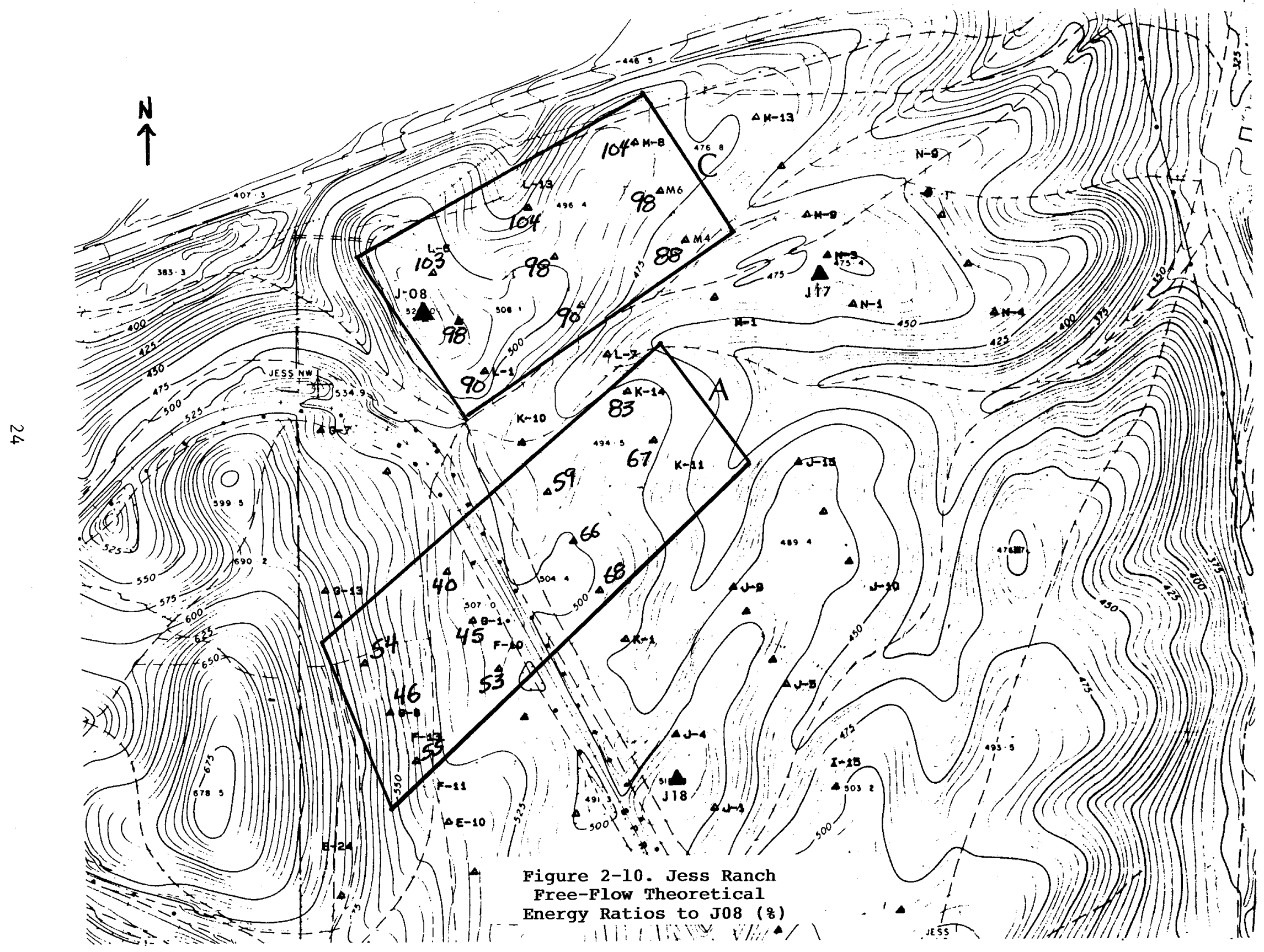




\section{SECTION 3.0 DATA ANALYSIS}

\subsection{Direct Wake Effect Test}

The Direct Wake Effect case was the most basic of the tests for determining row-to-row wake deficits. In this test case, an upwind row was switched on and off, and the downwind row remained on. The rows are separated by about 8-1/2 D. The downwind row is the test row, and the energy production data from this row were sorted into two classes: samples with the upwind row on and samples with the upwind row off. For additional discussion of test methodology, see Section 2.4. Six direct wake effect tests were conducted. Test 非 was aborted after $4 \mathrm{~h}$ because of high winds. Test $\equiv 6$ ended prematurely because of 1 ow winds. The tests took place on:

1. Souza-C group, August 7, 1987, 15:50-24:00 PDT (8 h)

2. Jess-A group, September 25, 1987, 09:00-19:00 PDT (10 h)

3. Souza-C group, October 1-2, 1987, 14:30-01:30 PDT (11 h)

4. Jess-C group, July 18, 1988, 18:00-22:10 PDT (4 h)

5. Jess-C group, July $20,1988,12: 10-22: 20$ PDT $(10 \mathrm{~h})$

6. Jess-C group, July $21,1988,17: 10-23: 20$ PDT (6 h)

In the first test, two rows of buffer turbines, upwind and crosswind of the test array, were turned off for the duration of the test. After several tests were conducted, a review meeting took place in Livermore with the project technical monitor from PNL, the project manager from AEC, and the author. At this meeting, it was decided that using crosswind buffer turbines should be discontinued, as it appeared that they might be providing "wind corridors" down the sides of the test array that could artificially reduce wake deficits at the end turbines in a given row. In the last four tests, the crosswind buffer turbines were cycled on and off with the other upwind turbines in their row. This later proved to be helpful in interpreting the data from the Jess-A group.

\subsubsection{Test 1 Analysis, Souza-C, August 7, 1987}

Table 3-1.a is the data listing for the August 7, 1987 test on Souza-C. A complete description of the format of the data can be found on page 11. Spacing between the two rows used in this array is only $6.8 \mathrm{D}$. Wind direction data were unavailable for this analysis; however, the winds were generally from the southwest, based on visual observation. Mean wind speed was about $22 \mathrm{mph}$ at the reference anemometer $\mathrm{s} 13$ and about $20 \mathrm{mph}$ at site $\mathrm{s} 27$. Ten-min wind speeds remained below $30 \mathrm{mph}$ for the entire test.

The mean wind speeds at both reference anemometers were slightly higher during the period with upwind turbines on. This introduces a slight bias to the data. In this analysis, and in a few others as well, the following methodology was used to try to reduce or eliminate this type of bias. Because the data records are sorted by increasing wind speed, omission of one data record at the beginning or end of the data set reduces the wind speed difference between periods. In this particular analysis, the last record (highest wind speed) was eliminated from the second test period. An additional set of means 
Table 3-1.a Souza-C Direct Wake Test Analysis 1

FOR WINDFARM: SOUZA RANCH WINDEARM

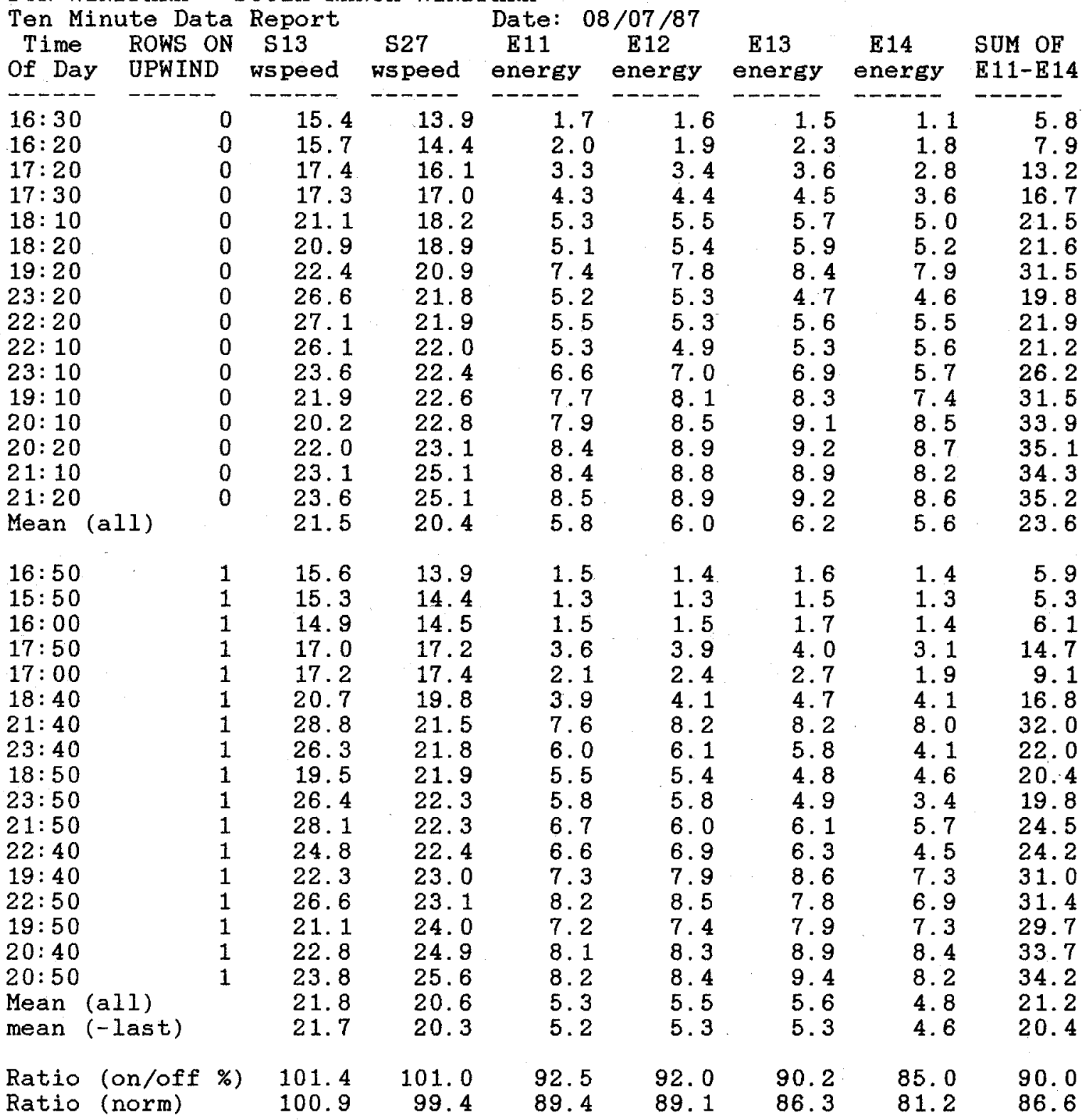


was then calculated for this normalized data set (see line marked "mean [-1ast]"), and a second set of ratios was calculated between the two test periods (see line marked "Ratio [Norm]"). The second set of ratios shows that the mean wind speeds at the two upwind anemometers have smaller differences between periods. Thus, there is probably a reduction in the bias.

The energy ratios calculated between these two periods show the energy deficit during the period when the upwind turbines were on line. In the first set of ratios calculated with the entire data set, the four test turbines had an energy ratio of $90 \%$, i.e., there was a $10 \%$ energy deficit in spite of an increase of $1 \%$ or more in wind speed. Using the second set of ratios with roughly the same wind speed in both test periods, the energy ratio was $86.6 \%$. This is equivalent to an energy deficit of $13.4 \%$. There is a pattern to the energy deficits within the test row, with the smallest deficits (about $11 \%$ ) at turbines E11 and E12. The deficits increase along the row to $18.8 \%$ at turbine E14. There are two possible explanations for this pattern -- the wind direction or the terrain. (The wind direction data are not available). It is interesting to note that (1) the elevation decreases slightly along the row, approaching E14; (2) E14 is the lowest producer in the row; and (3) speed ratios from the free-flow data study showed a progressive decrease in E14. Thus, the slight decrease in elevation within this row contributes to a natural decrease in available energy and an increase in the wake deficit. Wind speed data from the turbine anemometers were not available for this test.

The statistical significance using the "Student's" $t$ distribution test for both the row deficit of $13.4 \%$ and the turbine E14 deficit of $18.8 \%$ was 0.80 . This indicates that there is a $20 \%$ possibility that these results could have occurred by chance.

\subsubsection{Test 2 Analysis, Jess-A, September 25, 1987}

Table 3-1.b is the data 1isting for the September 25, 1987 test on Jess-A. spacing between the two test rows used in this array is $9.5 \mathrm{D}$. Turbines F9, F10, G1, G2, and G3 were the upwind turbines that were switched on and off. Winds were from the west-southwest at about $20 \mathrm{mph}$, and the two test periods had only a $0.1 \mathrm{mph}$ difference $(0.4 \%)$ at the upwind reference anemometer J08. Wind speeds measured at the $35-\mathrm{ft}$ level at turbines $\mathrm{K} 3$, K5, and $\mathrm{K} 7$ were considerably lower, with a range from about $13 \mathrm{mph}$ to $15 \mathrm{mph}$. However, this is within the range of expected wind speeds at these turbines based on the free-flow speed ratios of about 0.70 , as shown on Figure 2-9. It should be noted that there were three $10-\mathrm{min}$ data records from turbine $\mathrm{K} 7$ that were questionable. One problem arose in the 09:50 record when the turbine faulted and was reset. It was off 1 ine for about 2 min out of the 10-min data period. An adjustment was made to this record based on the mean ratio of production to turbine K6. At 1800 , the CTM failed and was replaced about a $30 \mathrm{~min}$ later. There were two missing 10-min records (18:10 and 18:20), and the energy at $\mathrm{K} 7$ was estimated again, based on the mean energy ratio to $\mathrm{K} 6$.

Table 3-1.b shows the ratios of energy between the two periods. Turbine K2 was included in the analysis even though it was not a part of the Jess-A array. As in the first test, there was a significant drop in energy when the upwind turbines were switched on 1 ine. The mean energy ratio was $89.5 \%$, which is equivalent to a $10.5 \%$ energy deficit. A number of samples had wind directions with a westerly component that was too high for good alignment. 
Iable 3-1.b Jess-1 Direct lake fest dnalysis

JBSS BAHCH 09/25/87

\begin{tabular}{|c|c|c|c|c|c|c|c|c|c|c|}
\hline $\begin{array}{l}\text { Tive } \\
\text { of Day }\end{array}$ & $\begin{array}{l}\text { rons on } \\
\text { uprind }\end{array}$ & $\begin{array}{c}\text { J08 } \\
\text { nspeed }\end{array}$ & $\begin{array}{c}\text { J08 } \\
\text { n.dir. }\end{array}$ & $\begin{array}{c}\mathrm{R} 02 \\
\text { energy }\end{array}$ & $\begin{array}{l}\text { R03 } \\
\text { energy }\end{array}$ & $\begin{array}{l}\text { R04 } \\
\text { enerer }\end{array}$ & $\begin{array}{c}r 05 \\
\text { energy }\end{array}$ & $\begin{array}{c}\text { rob } \\
\text { energy }\end{array}$ & $\begin{array}{c}\text { rof } \\
\text { energy }\end{array}$ & $\begin{array}{l}\text { sue of } \\
\mathrm{K} 02-\mathrm{R} 07\end{array}$ \\
\hline - - & & - & 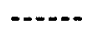 & - & ...... & - & ח- & - & ----- & $\cdots$ \\
\hline$: 10$ & 0 & 16.5 & 245 & 1.8 & 1.6 & 1.2 & 1.5 & 1.7 & 1.4 & 9.8 \\
\hline $5: 10$ & 0 & 17.1 & 255 & 1.2 & 1. & 1.3 & 1.1 & 1.3 & 1.2 & 7.8 \\
\hline $3: 10$ & 0 & 17.3 & 260 & 1.3 & 1.5 & 1.6 & 1.7 & 1.6 & 1.1 & 9.1 \\
\hline $3: 20$ & 0 & 17.3 & 252 & 1.7 & 1.6 & 1.9 & 2.1 & 1.8 & 1.1 & 10.5 \\
\hline $6: 20$ & 0 & 17.5 & 248 & 1.3 & 1.4 & 1.3 & 1.6 & 1.6 & 1.3 & 8.5 \\
\hline $5: 20$ & 0 & 17.6 & 253 & 1.3 & 1. & 1.4 & 1.7 & 1.5 & 1.2 & 8.5 \\
\hline $2: 20$ & 0 & 18.6 & 252 & 1.1 & 1.5 & 1.7 & 2.1 & 1.8 & 1.6 & 10.1 \\
\hline $4: 20$ & 0 & 18.9 & 246 & 2.2 & 2.4 & 2.5 & 2.3 & 2.4 & 2.1 & 13.9 \\
\hline $1: 20$ & 0 & 18.9 & 250 & 1.7 & 1.6 & 1.6 & 1.8 & 1.7 & 1.5 & 9.9 \\
\hline $1: 10$ & 0 & 19.1 & 248 & 0.7 & 1.3 & 1.2 & 1.5 & 1.1 & 1.4 & 7.5 \\
\hline $12: 10$ & 0 & 19.2 & 245 & 1.6 & 1.8 & 1.5 & 1.7 & 1.7 & 1.5 & 9.8 \\
\hline$: 10$ & 0 & 19.2 & 260 & 1.9 & 2.3 & 2.6 & 2.8 & 2.6 & 1.9 & 14.1 \\
\hline $8: 20$ & 0 & 19.8 & 245 & 2.8 & 2.8 & 2.9 & 3.3 & 3.2 & e2.9 & 17.9 \\
\hline $7: 20$ & 0 & 20.7 & 253 & 1.5 & 1.5 & 1.7 & 2.1 & 3 & 3.3 & 13.7 \\
\hline $8: 10$ & 0 & 20.7 & 250 & 2.6 & 3.3 & 3.1 & 2.2 & 2.8 & e2. 6 & 16.6 \\
\hline $7: 10$ & 0 & 21.1 & 262 & 2 & 2.1 & 2.6 & 3.3 & 3.1 & 2.7 & 15.8 \\
\hline $0: 20$ & 0 & 22.7 & 250 & 3.7 & 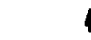 & 3 & 3 & 3.5 & 3.7 & 20.9 \\
\hline$: 10$ & 0 & 24.1 & 253 & 4 & 4.1 & 3.8 & 3.5 & 3.4 & 3.9 & 22.7 \\
\hline : & 0 & 24.3 & 243 & 4 & 3.3 & 3 & 3.9 & 3.2 & 2.3 & 19.7 \\
\hline $9: 20$ & 0 & 24.8 & 245 & 2.8 & 2.9 & 3.4 & 3.5 & 3 & 2.8 & 18.4 \\
\hline Hean: & & 19.8 & 251 & 2.1 & 2.2 & 2.2 & 2.1 & 2.3 & 2.1 & 13.2 \\
\hline lean for & & 20.3 & 250 & 2.2 & 2.3 & 23 & 2.5 & 2.5 & 2.2 & 14.0 \\
\hline
\end{tabular}

\begin{tabular}{|c|c|c|c|c|c|c|c|c|c|c|c|c|}
\hline $15: 10$ & 17.1 & 239 & 1.2 & 1.5 & 1.5 & 1.6 & 1.5 & 1.3 & 8.6 & 12.3 & 12.7 & 11.4 \\
\hline $17: 50$ & 21.7 & 239 & 2.6 & 3 & 2.6 & 2.3 & 2.6 & 2.6 & 15.7 & 15.1 & 14.4 & 14.3 \\
\hline $15: 50$ & 17.1 & 241 & 1.5 & 1.5 & 1 & 1.4 & 1.5 & 1.5 & 8.1 & 12.1 & 12.6 & 12.5 \\
\hline $16: 10$ & 19.6 & 243 & 2.1 & 2 & 1.8 & 2 & 2.1 & 2.2 & 12.2 & 13.2 & 13.5 & 14.2 \\
\hline $18: 10$ & 20.5 & 245 & 2.1 & 2.7 & 2.6 & 1.6 & 1.8 & 1.7 & 12.5 & 14.1 & 12.8 & 13.2 \\
\hline $18: 50$ & 21.5 & 245 & 3 & 3.1 & 2.6 & 2.3 & 2.8 & 2.1 & 15.9 & 14.7 & 14.4 & 13.7 \\
\hline $09: 10$ & 24.4 & 248 & 2.9 & 3.1 & 2.8 & 2.3 & 3.1 & 3.3 & 17.5 & 15.1 & 14.6 & 15 \\
\hline 17:10 & 20.8 & 249 & 1.7 & 1.5 & 1.3 & 1.5 & 2 & 2.4 & 10.4 & 12.4 & 12.7 & 14.7 \\
\hline $09: 50$ & 26.1 & 249 & 2.1 & 2.3 & 2.1 & 2 & 2.5 & e2.4 & 13.7 & 14.2 & 13.9 & el3.7 \\
\hline $13: 50$ & 18.9 & 250 & 1.7 & 1.8 & 1.5 & 1.7 & 1.6 & 1.4 & 9.7 & 12.6 & 13 & 12.2 \\
\hline $11: 40$ & 18.5 & 252 & 1.3 & 1.6 & 1.5 & 1.4 & 1.4 & 1.3 & 8.5 & 12.5 & 12.6 & 12.6 \\
\hline $16: 50$ & 20.8 & 252 & 2 & 1.9 & 2.3 & 3.3 & 3.2 & 3 & 15.7 & 13.4 & 15.8 & 15.2 \\
\hline $12: 50$ & 17.1 & 253 & 1.3 & 1.7 & 1.7 & 1.4 & 1.4 & 1.4 & 8.9 & 12.5 & 12.6 & 12 \\
\hline $11: 50$ & 19.3 & 253 & 1.3 & 1.2 & 1.3 & 1.5 & 1.6 & 1.5 & 8.1 & 11.8 & 12.8 & 12.9 \\
\hline $14: 50$ & 18.1 & 255 & 1.6 & 1.5 & 1.2 & 1.6 & 1.7 & 1.5 & 9.1 & 12.1 & 13.3 & 13 \\
\hline $10: 50$ & 20.4 & 255 & 1.9 & 2.1 & 2.3 & 2.1 & 2.2 & 2.1 & 13 & 13.8 & 13.6 & 13.9 \\
\hline $10: 40$ & 21.3 & 255 & 2.1 & 2.2 & 2.3 & 2.3 & 3.1 & 3.3 & 15.3 & 13.7 & 14.2 & 15.2 \\
\hline $14: 40$ & 17.4 & 256 & 1.5 & 1.5 & 1.5 & 1.6 & 1.7 & 1.5 & 9.3 & 11.9 & 13.1 & 12.4 \\
\hline $13: 40$ & 18.5 & 256 & 1.6 & 2.3 & 2.6 & 2.6 & 2.1 & 1.9 & 13.1 & 13.7 & 14.6 & 13.2 \\
\hline $12: 40$ & 17.9 & 257 & 1.3 & 1.6 & 2.1 & 2.2 & 2.1 & 1.7 & 11 & 12.9 & 14.4 & 13 \\
\hline Kean: & 19.8 & 249 & 1.9 & 2.0 & 1.9 & 1.9 & 2.1 & 2.0 & 11.8 & 13.2 & 13.6 & 13.1 \\
\hline ND<255 & 20.2 & 247 & 1.9 & 2.1 & 1.9 & 1.9 & 2.1 & 2.0 & 11.9 & 13.3 & 13.5 & 13.4 \\
\hline Ratio on/off $(x)$ & 100.4 & & 89.1 & 92.2 & 89.1 & 81.3 & 90.7 & 95.2 & 89.5 & 98.3 & 95.2 & 99.9 \\
\hline - $M D<255$ & 99.9 & & 88.5 & 89.3 & 82.4 & 74.3 & 84.7 & 89.6 & 84.6 & 97.1 & 92.7 & 97.7 \\
\hline " Turbine dner & ter Speed: & & $N / h$ & 97.1 & $\mathbb{N} / \mathbf{A}$ & 92.7 & $\mathbb{H} / \mathrm{h}$ & 97.7 & & & & \\
\hline & tim & & & & & & & & & & 1 & of \\
\hline
\end{tabular}


Table 3-1. b Jess-A Direct Wake Test Analysis

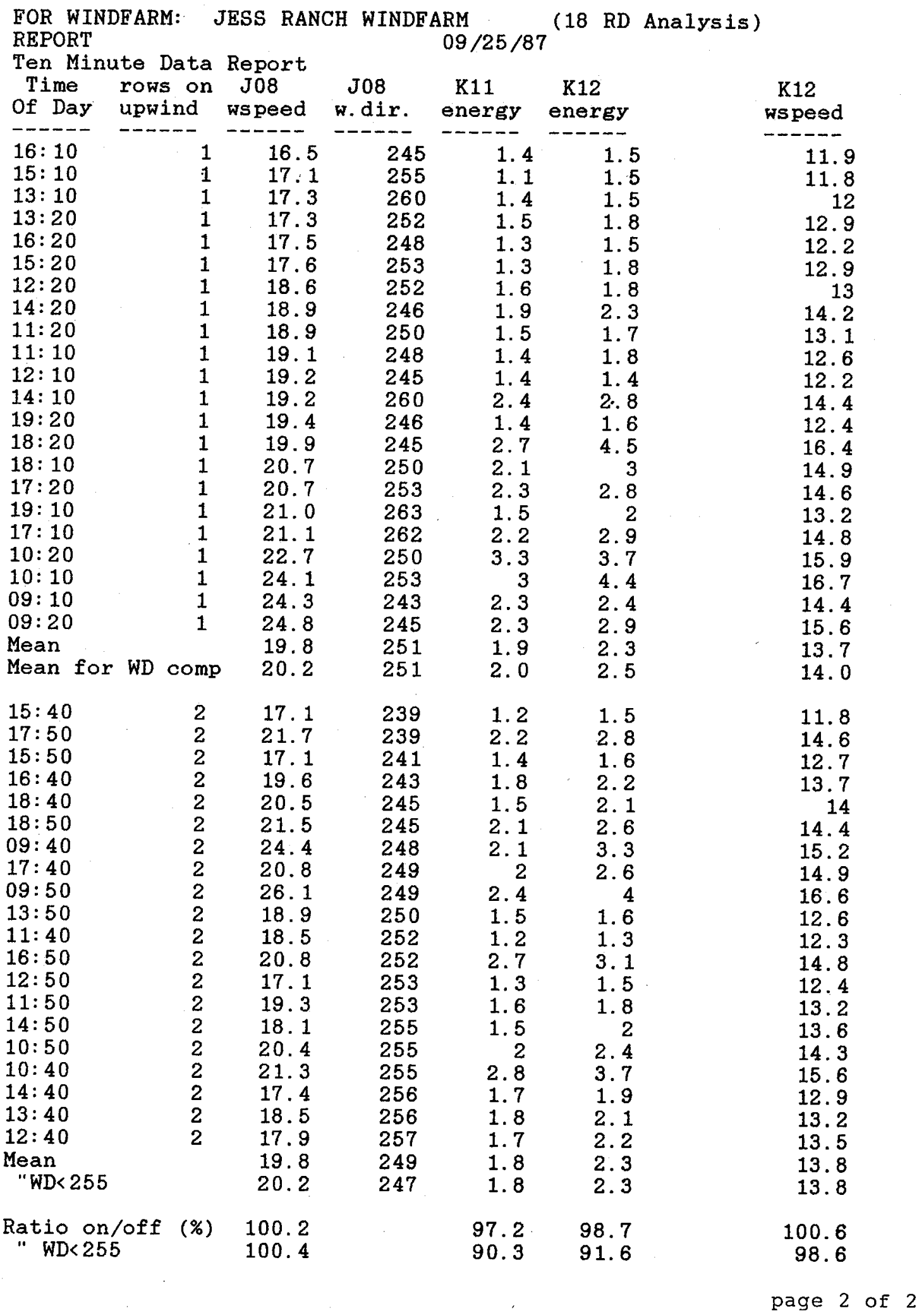


The expected wake trajectory associated with this direction would be south of the test row. When the samples with wind directions above $255^{\circ}$ were deleted, the mean energy ratio dropped to $84.6 \%$, which is equivalent to a $15.4 \%$ energy deficit. The deficit at turbine $\mathrm{K} 7$ at the northern end of the test row doubled when the wind direction data were screened. The largest energy deficit was near the center of the test row. The range of energy ratios was from $74.3 \%$ to $89.6 \%$, which is equivalent to energy deficits of $25.7 \%$ to $10.4 \%$. Wind speed data were analyzed from turbines $\mathrm{K} 3, \mathrm{~K} 5$, and $\mathrm{K} 7$. The table shows that the speed ratios ranged from $92.7 \%$ at $\mathrm{K} 5$ to $97.7 \%$ at $\mathrm{K} 7$. These are equivalent to speed deficits of $7.3 \%$ and $2.3 \%$, respectively. The speed deficits were quite small compared to the energy deficits. This is probably because the anemometers are below the wake centerline.

The statistical significance of the row energy deficit of $15.4 \%$ was 0.90 . The energy deficit of $25.7 \%$ at turbine $\mathrm{K} 5$ was statistically significant at the 0.99 level. The speed deficit at $\mathrm{K} 5$ of $7.3 \%$ was also significant at the 0.99 level.

The second page of Table 3-1.b is an analysis of the row downwind of the principal test row discussed above. This row is $18 \mathrm{D}$ downwind of the turbines that were switched on and off and $8 \mathrm{D}$ downwind of the principal test row. This analysis illustrates the persistence of the wake deficit. Although there are four turbines in this test row, the apparent wake trajectory was to the south of turbines $\mathrm{K} 13$ and K14. These turbines had negligible wake deficits. The table 1 ists the data from turbines $\mathrm{K} 11$ and $\mathrm{K} 12$. As in page one of this table, means were calculated for the entire data set and for samples with wind direction less than $255^{\circ}$. The ratios for the entire data set show negligible deficits. However, when the data were screened by direction, the energy ratios at $\mathrm{K} 11$ and $\mathrm{K} 12$ were $90.3 \%$ and $91.6 \%$, respectively. These are equivalent to $9.7 \%$ and $8.4 \%$ energy deficits. Wind speed data from turbine K12 were also analyzed but the deficit was negligible.

The energy deficits are quite large considering the 18-D distance. Turbines $\mathrm{K} 11$ and $\mathrm{K} 12$ are roughly downwind of $\mathrm{K} 6$ and $\mathrm{K} 7$. $\mathrm{K} 6$ and $\mathrm{K} 7$ had energy deficits of about $13 \%$, and $\mathrm{K} 11$ and $\mathrm{K} 12$ deficits were $9 \%$. Thus the deficit in this $18-\mathrm{D}$ row was about $70 \%$ of the deficit in the $9.5-\mathrm{D}$ row.

Figure 3-1.a is a topographic map of the Jess-A array and has the individual turbine energy deficits plotted as bars at each turbine. The length of the bar is proportional to the deficit and the bar is plotted parallel to the mean wind direction. The figure shows which turbines were switched on and off, and the individual turbine deficits are listed at the bottom of the figure.

\subsubsection{Test 3 Analysis, Souza-C, October 1-2, 1987}

Table 3-1.c is the data listing for the October 1-2, 1987 test on Souza-C. Recall that spacing between rows is only $6.8 \mathrm{D}$. Mean winds were from the south-southwest at about $22 \mathrm{mph}$. The energy ratios between periods show a decrease in energy when the upwind row was on 1 ine, but the energy deficit was lower than in the first test on Souza. The energy ratio at turbines E12 through E14 was $92.4 \%$, which is equivalent to a $7.6 \%$ energy deficit. As in the previous test on Jess, there were some records that had to be screened because of wind direction alignment problems. Because of the southerly wind direction component, turbine $E 11$ was at the edge of the expected wake and was 


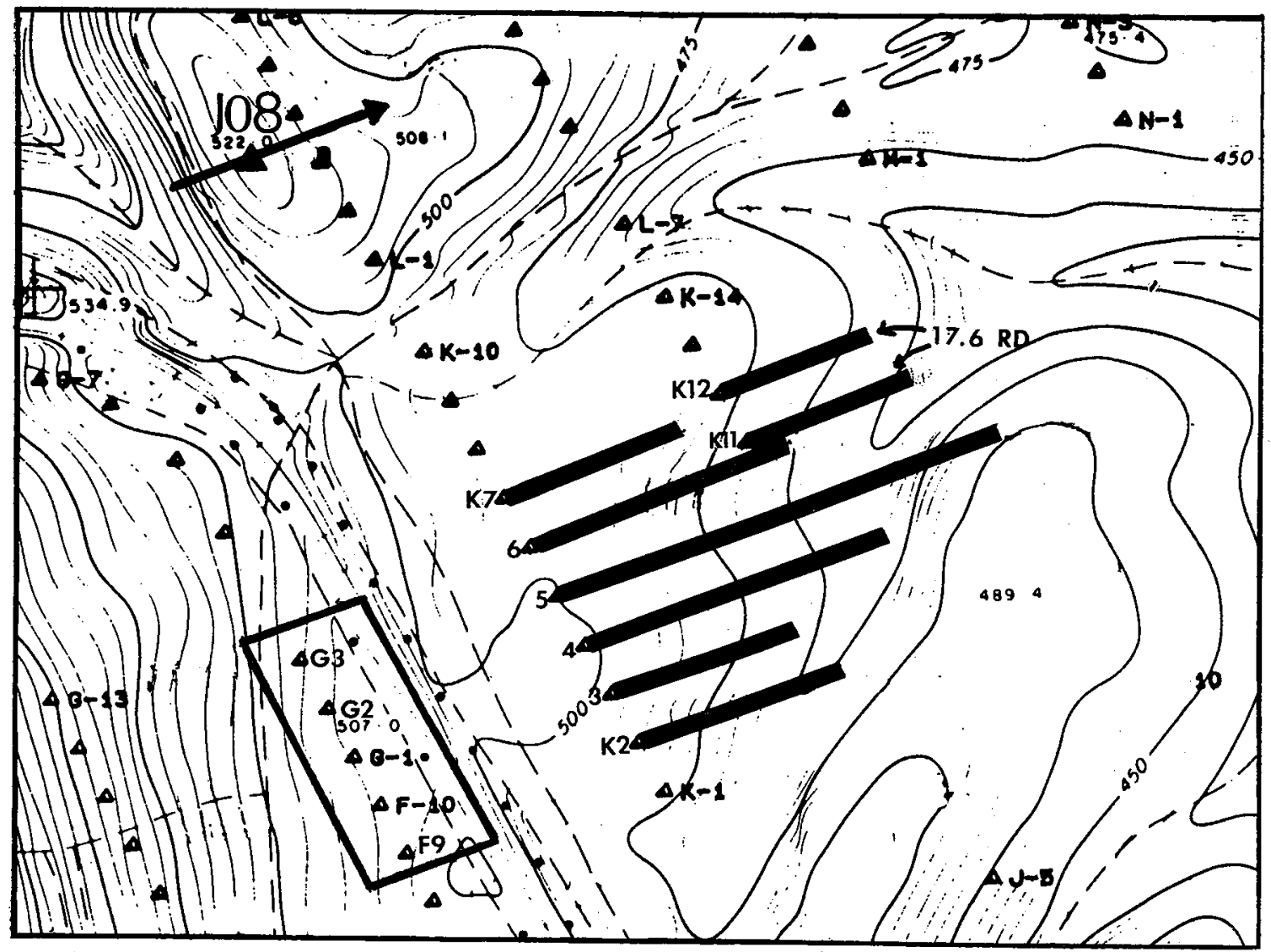

Figure 3-1.a. Jess-A Direct Wake Effect Test Individual Turbine Deficits

Sept 25, 1987 test conditions at reference anemometer, J-08: mean speed $=20.2 \mathrm{mph}$, mean direction $=250$ degrees.

\section{KEY}

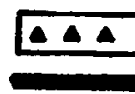

$$
\begin{aligned}
& =\text { turbines switched on and off } \\
& =\% \text { wake energy deficit, } 1 "=10 \%
\end{aligned}
$$

Deficits

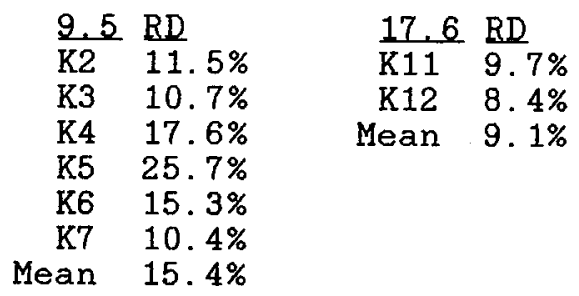


Table 3-1.c Souza-C Direct Hake Test Analysis 2

Ien Hinute Data Report

COR WINDPARH: SOOZA RANCH HINDPARK

REPORT 10/01/87-10/02/87

Ten Vinute Data Report

Tiwe ross on $\$ 13 \quad 513 \quad \$ 27 \quad 811 \quad 812 \quad$ B13 814 sun of

Of Day upwind uspeed n.dir. "speed energy energy energg energy B12-814

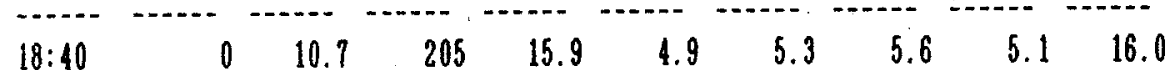

$\begin{array}{llllllllllll}18: 40 & 0 & 10.7 & 205 & 15.9 & 4.9 & 5.3 & 5.6 & 5.1 & 16.0 & 19.1 & 19.6 \\ 19: 50 & 0 & 14.9 & 211 & 16.6 & 1.3 & 4.1 & 3.8 & 3.2 & 11.1 & 17.3 & 16.7 \\ 18: 50 & 0 & 16.4 & 160 & 17.2 & 5.9 & 6.1 & 6.4 & 6.0 & 18.5 & 20.7 & 21.1 \\ 17: 50 & 0 & 17.4 & 222 & 19.9 & 6.3 & 5.8 & 5.7 & 5.1 & 16.6 & 19.7 & 19.1 \\ 19: 40 & 0 & 18.8 & 194 & 19.0 & 5.5 & 5.1 & 5.0 & 4.1 & 14.2 & 18.6 & 18.1 \\ 14: 50 & 0 & 19.1 & 222 & 21.3 & 4.3 & 4.5 & 5.3 & 5.3 & 15.1 & 17.4 & 19.7 \\ 16: 50 & 0 & 19.6 & 217 & 19.0 & 6.5 & 5.2 & 4.7 & 4.1 & 14.0 & 18.8 & 18.3 \\ 15: 50 & 0 & 19.6 & 233 & 19.2 & 4.1 & 3.2 & 3.5 & 3.4 & 10.1 & 15.1 & 16.9 \\ 15: 40 & 0 & 19.8 & 219 & 20.2 & 4.0 & 4.1 & 4.5 & 4.0 & 12.5 & 16.7 & 17.5 \\ 20: 50 & 0 & 20.6 & 219 & 25.1 & 6.5 & 7.0 & 7.3 & 6.7 & 21.0 & 21.2 & 22.9 \\ 20: 40 & 0 & 20.6 & 228 & 22.4 & 5.3 & 5.3 & 5.5 & 4.6 & 15.4 & 18.1 & 18.8 \\ 16: 40 & 0 & 20.7 & 217 & 19.5 & 6.5 & 5.3 & 4.1 & 3.6 & 13.0 & 19.2 & 17.3 \\ 14: 40 & 0 & 20.9 & 228 & 20.9 & 4.8 & 5.0 & 5.1 & 4.8 & 15.2 & 18.1 & 18.7 \\ 17: 40 & 0 & 22.2 & 225 & 21.7 & 8.4 & 8.4 & 8.2 & 7.7 & 24.3 & 24.5 & 24.3 \\ 01: 50 & 0 & 22.7 & 211 & 31.3 & 9.5 & 9.2 & 8.1 & 6.3 & 23.6 & 30.2 & 22.7 \\ 22: 40 & 0 & 23.1 & 197 & 26.0 & 9.3 & 9.5 & 9.6 & 8.8 & 27.9 & 31.3 & 28.4 \\ 22: 50 & 0 & 23.2 & 191 & 26.0 & 9.6 & 9.8 & 10.0 & 9.7 & 29.5 & 33.8 & 31.6 \\ 01: 40 & 0 & 24.9 & 211 & 31.7 & 9.5 & 9.0 & 8.2 & 7.2 & 24.4 & 29.8 & 24.0 \\ 21: 50 & 0 & 25.1 & 200 & 28.1 & 8.6 & 8.6 & 8.7 & 8.3 & 25.6 & 26.4 & 25.9 \\ 21: 40 & 0 & 26.7 & 186 & 26.4 & 8.7 & 9.0 & 8.9 & 8.2 & 26.1 & 28.2 & 25.8 \\ 23: 50 & 0 & 27.7 & 194 & 31.1 & 9.7 & 9.7 & 9.8 & 9.2 & 28.7 & 32.9 & 29.6 \\ 23: 40 & 0 & 29.1 & 188 & 31.1 & 9.7 & 9.8 & 9.9 & 9.4 & 29.1 & 33.5 & 30.6 \\ 00: 40 & 0 & 29.2 & 208 & 31.6 & 9.7 & 9.8 & 9.6 & 8.9 & 28.3 & 34.6 & 29.8 \\ \text { 00:50 } & 0 & 29.6 & 208 & 31.5 & 9.7 & 9.8 & 9.7 & 8.5 & 28.0 & 39.8 & 27.6 \\ & & & & & & & & & & & \\ \text { Hean(a11 data) } & 21.8 & 208 & 23.9 & 7.1 & 7.0 & 7.0 & 6.3 & 20.3 & 24.1 & 22.7 \\ \text { Hean for } & \text { conp } & 20.0 & 211 & 22.2 & 6.5 & 6.3 & 6.3 & 5.7 & 18.3 & 21.9 & 21.1\end{array}$

Page 1 of 2 
Pable 3-1.c Souza-C Direct Hake Test Analysis 2

$10 / 01 / 87-10 / 02 / 87$

\begin{tabular}{|c|c|c|c|c|c|c|c|c|c|c|c|}
\hline $\begin{array}{l}\text { Tine } \\
\text { of Day }\end{array}$ & $\begin{array}{l}\text { rons on } \\
\text { uprind }\end{array}$ & $\begin{array}{l}\text { S13 } \\
\text { ispeed }\end{array}$ & $\begin{array}{l}\text { S13 } \\
\text { \$.dir. }\end{array}$ & $\begin{array}{l}\text { S27 } \\
\text { nspeed }\end{array}$ & $\begin{array}{l}\text { B11 } \\
\text { energy }\end{array}$ & $\begin{array}{l}\text { B12 } \\
\text { energy }\end{array}$ & $\begin{array}{l}813 \\
\text { energy }\end{array}$ & $\begin{array}{l}\text { B14 } \\
\text { energy }\end{array}$ & $\begin{array}{l}\text { sun of } \\
\text { B12-814 }\end{array}$ & $\begin{array}{l}812 \\
\text { qspeed }\end{array}$ & $\begin{array}{l}\text { B14 } \\
\text { sspeed }\end{array}$ \\
\hline $00: 10$ & 1 & 27.1 & 177 & 30.6 & 9.7 & 9.9 & 9.7 & 9.1 & 28.7 & 34.5 & 30.1 \\
\hline $22: 20$ & 1 & 24.5 & 180 & 25.5 & 9.3 & 9.6 & 9.4 & 8.8 & 27.8 & 31.4 & 28.6 \\
\hline $23: 20$ & 1 & 27.2 & 180 & 29.9 & 9.7 & 9.7 & 9.9 & 9.5 & 29.1 & 33.4 & 30.8 \\
\hline $23: 10$ & 1 & 26.5 & 186 & 27.4 & 9.1 & 9.4 & 9.5 & 8.7 & 27.6 & 31.1 & 28.1 \\
\hline $22: 10$ & 1 & 25.6 & 197 & 25.2 & 9.0 & 9.3 & 9.2 & 8.0 & 26.5 & 29.2 & 26.6 \\
\hline $00: 20$ & 1 & 29.3 & 200 & 29.4 & 9.6 & 9.7 & 9.6 & 8.8 & 28.1 & 33.1 & 28.9 \\
\hline $18: 20$ & 1 & 15.9 & 203 & 18.1 & 5.2 & 5.3 & 5.2 & 3.5 & 14.0 & 19.5 & 18.0 \\
\hline $19: 10$ & $i$ & 22.4 & 203 & 22.6 & 9.0 & 5.9 & 5.6 & 3.9 & 15.4 & 20.9 & 18.5 \\
\hline $19: 20$ & 1 & 21.9 & 203 & 22.4 & 5.9 & 5.2 & 4.4 & 4.1 & 13.7 & 19.1 & 18.9 \\
\hline $17: 10$ & 1 & 20.7 & 208 & 22.6 & 7.2 & 5.5 & 5.1 & 4.9 & 15.5 & 20.7 & 20.4 \\
\hline $01: 20$ & 1 & 26.5 & 208 & 30.2 & 9.6 & 9.5 & 9.2 & 8.5 & 27.2 & 32.6 & 26.6 \\
\hline $17: 20$ & 1 & 21.4 & 211 & 23.2 & 5.8 & 5.1 & 4.8 & 5.1 & 15.0 & 19.9 & 20.7 \\
\hline $01: 10$ & 1 & 24.1 & 211 & 30.2 & 9.6 & 9.6 & 9.7 & 8.9 & 28.2 & 33.4 & 27.9 \\
\hline $18: 10$ & 1 & 14.2 & 217 & 18.4 & 6.1 & 5.9 & 4.8 & 3.7 & 14.1 & 20.8 & 18.2 \\
\hline $21: 20$ & $i$ & 18.6 & 217 & 26.2 & 7.4 & 6.8 & 6.9 & 6.8 & 20.5 & 22.9 & 23.6 \\
\hline $20: 20$ & $i$ & 19.6 & 217 & 23.1 & 5.2 & 5.5 & 5.5 & 5.1 & 16.1 & 20.1 & 19.6 \\
\hline $16: 20$ & 1 & 18.1 & 217 & 18.3 & 4.6 & 3.3 & 3.2 & 2.9 & 9.1 & 16.4 & 16.7 \\
\hline $21: 10$ & 1 & 22.2 & 219 & 26.0 & 5.4 & 5.1 & 5.3 & 4.4 & 15.1 & 19.5 & 19.2 \\
\hline $20: 10$ & 1 & 17.1 & 222 & 20.5 & 3.6 & 3.5 & 4.1 & 3.7 & 11.3 & 16.6 & 16.9 \\
\hline $16: 10$ & 1 & 18.8 & 231 & 20.0 & 4.8 & 3.7 & 3.6 & 3.4 & 10.7 & 17.1 & 17.3 \\
\hline $15: 10$ & 1 & 21.4 & 233 & 19.1 & 3.5 & 3.6 & 3.9 & 3.0 & 10.5 & 16.9 & 16.9 \\
\hline $15: 20$ & 1 & 18.8 & 239 & 18.3 & 2.5 & 2.8 & 3.2 & 2.8 & 8.8 & 15.7 & 16.1 \\
\hline $\operatorname{lean}(\mathrm{a})$ & (data) & 21.9 & 208 & 24.0 & 6.8 & 6.6 & 6.1 & 5.8 & 18.8 & 23.9 & 22.2 \\
\hline Hean YDre & & 20.1 & 216 & 22.5 & 5.9 & 5.4 & 5.3 & 4.7 & 15.4 & 20.8 & 19.7 \\
\hline \multicolumn{12}{|c|}{ Bnergy ratios, turbines on/off $(\boldsymbol{x})$} \\
\hline all data & & 100.6 & & 100.5 & 95.8 & 93.3 & 92.4 & 91.5 & 92.4 & 98.9 & 97.8 \\
\hline KD $>200 \mathrm{de}$ & & 100.4 & & 101.5 & 89.9 & 85.3 & 84.0 & 82.1 & 83.9 & 94.8 & 93.3 \\
\hline \multicolumn{12}{|c|}{ Turbine anemoneter data: } \\
\hline \multirow{2}{*}{\multicolumn{5}{|c|}{ Speed ratios (all data): }} & H/A & 98.9 & N/A & 97.8 & & & \\
\hline & & & & & $1 / \mathrm{A}$ & 94.8 & N/A & 93.3 & & & \\
\hline \multicolumn{6}{|c|}{$\begin{array}{l}\text { Available porer ratios (W/sq. } \\
\text { " }\end{array}$} & $\begin{array}{l}97.6 \\
84.8\end{array}$ & & $\begin{array}{l}95.3 \\
79.5\end{array}$ & & & \\
\hline
\end{tabular}

Page 2 of 2 
not included in the row mean calculations. When the records with wind directions below $200^{\circ}$ were deleted, the mean energy ratio at E12 - E14 dropped to $83.9 \%$, which is equivalent to a $16.1 \%$ energy deficit. As in the other Souza test, the deficits became progressively larger towards E14. This is probably due to a combination of the wind direction during the test and terrain effects. Wind speed data from E12 and E14 were analyzed. The speed ratios were $94.8 \%$ and $93.3 \%$, respectively, which are equivalent to speed deficits of $5.2 \%$ and $6.7 \%$. Power density $\left(\mathrm{W} / \mathrm{m}^{2}\right)$ was calculated from these turbine anemometers. The power density deficits were $15.2 \%$ and $20.5 \%$, which are very close to the energy deficits at these turbines.

Statistical significance using the "Student's" $t$ test was calculated for the energy deficits with wind direction screening. The significance level was 0.90 for the row average and for turbine E14, which had the largest deficit. The significance level for the turbine El4 speed deficit was also 0.90 .

\subsubsection{Souza-C Combined File}

Two of the tests discussed above were conducted on the same set of turbines, Souza-C. Data from the two tests were combined into one file for further analysis. The records discussed above with wind directions below $200^{\circ}$ were not included in this file. Table 3-1.d 1 ists these data with the addition of column 4, which shows the wind power density at $\mathrm{S} 13$ in $\mathrm{W} / \mathrm{m}^{2}$ (not corrected for ambient air density). Means were calculated for the entire combined data set as well as low, middle, and high wind speed subsets. There are four sets of ratios as well.

A comparison of the ratios shows that the low and middle speed classes (approximately $17.5 \mathrm{mph}$ and $21.5 \mathrm{mph}$ means) had almost the same energy deficits, about 15\%. By contrast, the high speed class (26.5 mph) had lower deficits, about 11\%. Recall that the Nordtank power curve is less steep in this region, and the $\mathrm{CP}_{\mathrm{p}}$ is decreasing, so smaller deficits would be expected.

Statistical significance of the deficits for the row average was 0.95 . Turbine E14, which had the largest deficit, had a significance level of 0.975 .

Figure 3-1.b is a topographic map of the Souza study array. The wake deficits measured (in percent) during these two tests are plotted as bars at the individual turbines, parallel to the mean wind direction. The length of each bar is proportional to the deficit; 1 in. equals a $10 \%$ deficit.

\subsubsection{Test 5 Analysis, Jess-C, July 20, 1988}

Table 3-1.e is the data listing for the July 20, 1988 test on Jess-C. (Test 4 was conducted two days earlier at the same array, but was aborted because of high winds. The results of that test are discussed in section 3.1.7).

Spacing between rows in this test array was $7.8 \mathrm{D}$. Turbines L7 through L13 were switched on and off during the test. The turbines in the next upwind row, L1 through L6, remained off line for the entire test. Winds were from the west to west-southwest and the mean speed was $26.6 \mathrm{mph}$ at J08, and $22 \mathrm{mph}$ to $25 \mathrm{mph}$ at turbines M4 through M8. These speeds are higher than the three tests discussed previously. There was a $0.3 \mathrm{mph}$ difference in mean speeds at the upwind anemometer, between the two test periods, so a second set of means 
Table 3-1.d Combined File, Souza-C Direct Wake Test Analysis

FOR WINDFARM: SOUZA RANCH WINDFARM

\begin{tabular}{|c|c|c|c|c|c|c|c|c|}
\hline $\begin{array}{l}\text { Time } \\
\text { Of Day }\end{array}$ & $\begin{array}{l}\text { ROWS ON } \\
\text { UPWIND }\end{array}$ & $\begin{array}{c}\text { S13 } \\
\text { ws peed }\end{array}$ & $\mathrm{W} / \mathrm{sq}^{\mathrm{S} 13} \mathrm{M}$ & $\begin{array}{l}\text { E11 } \\
\text { energy }\end{array}$ & $\begin{array}{l}\text { E12 } \\
\text { energy }\end{array}$ & $\begin{array}{l}\text { E13 } \\
\text { energy }\end{array}$ & $\begin{array}{l}\text { E14 } \\
\text { energy }\end{array}$ & $\begin{array}{l}\text { SUM OF } \\
\text { E11-E14 }\end{array}$ \\
\hline $18: 40$ & 0. & 10.7 & 67.0 & 4.9 & 5.3 & 5.6 & 5.1 & 20.9 \\
\hline $19: 50$ & 0 & 14.9 & 180.9 & 4.3 & 4.1 & 3.8 & 3.2 & 15.4 \\
\hline $16: 30$ & 0 & 15.4 & 199.8 & 1.7 & 1.6 & 1.5 & 1.1 & 5.82 \\
\hline $16: 20$ & 0 & 15.7 & 211. & 2.0 & 1.9 & 2.3 & 1.8 & 7.91 \\
\hline $18: 50$ & 0 & 16.4 & 241.3 & 5.9 & 6.1 & 6.4 & 6.0 & 24.4 \\
\hline $17: 30$ & 0 & 17.3 & 283.2 & 4.3 & 4.4 & 4.5 & 3.6 & 16.68 \\
\hline $17: 20$ & 0 & 17.4 & 288.2 & 3.3 & 3.4 & 3.6 & 2.8 & 13.16 \\
\hline $17: 50$ & 0 & 17.4 & 288.2 & 6.3 & 5.8 & 5.7 & 5.1 & 22.9 \\
\hline $19: 40$ & 0 & 18.8 & 363.5 & 5.5 & 5.1 & 5.0 & 4.1 & 19.7 \\
\hline $14: 50$ & 0 & 19.1 & 381.1 & 4.3 & 4.5 & 5.3 & 5.3 & 19.4 \\
\hline $16: 50$ & 0 & 19.6 & 411.9 & 6.5 & 5.2 & 4.7 & 4.1 & 20.5 \\
\hline $15: 50$ & 0 & 19.6 & 411.9 & 4. 1 & 3.2 & 3.5 & 3.4 & 14.2 \\
\hline $15: 40$ & 0 & 19.8 & 424.6 & 4.0 & 4.1 & 4.4 & 4.0 & 16.5 \\
\hline $20: 10$ & 0 & 20.2 & 450.9 & 7.9 & 8.5 & 9.1 & 8.5 & 33.93 \\
\hline $20: 40$ & 0 & 20.6 & 478.2 & 5.3 & 5.3 & 5.5 & 4.6 & 20.7 \\
\hline $20: 50$ & 0 & 20.6 & 478.2 & 6.5 & 7.0 & 7.3 & 6.7 & 27.5 \\
\hline $16: 40$ & 0 & 20.7 & 485.2 & 6.5 & 5.3 & 4.1 & 3.6 & 19.5 \\
\hline $14: 40$ & 0 & 20.9 & 499.4 & 4.8 & 5.0 & 5.4 & 4.8 & 2 \\
\hline $18: 20$ & 0 & 20.9 & 499.4 & 5.1 & 5.4 & 5.9 & 5.2 & 21.6 \\
\hline $18: 10$ & 0 & 21.1 & 513.8 & 5.3 & 5.5 & 5.7 & 5.0 & 21.4 \\
\hline $19: 10$ & 0 & 21.9 & 574.5 & 7.7 & 8.1 & 8.3 & 7.4 & 31.49 \\
\hline $20: 20$ & 0 & 22 & 582.4 & 8.4 & 8.9 & 9.2 & 8.7 & 35.11 \\
\hline $17: 40$ & 0 & 22.2 & 598.5 & 8.4 & 8.4 & 8.2 & 7.7 & 32.7 \\
\hline $19: 20$ & 0 & 22.4 & 614.8 & 7.4 & 7.8 & 8.4 & 7.9 & $31: 46$ \\
\hline $01: 50$ & 0 & 22.7 & 639 & 9.5 & 9.2 & 8.1 & 6.3 & 33.1 \\
\hline $22: 40$ & 0 & 23.1 & 674.3 & 9.3 & 9.5 & 9.6 & 8.8 & 37. \\
\hline $21: 10$ & 0 & 23.1 & .3 & 8.4 & .8 & 8.9 & 8.2 & 34.3 \\
\hline $22: 50$ & 0 & 23.2 & 683.0 & 9.6 & 9.8 & 10.0 & 9.7 & 39. \\
\hline $21: 20$ & 0 & 23.6 & 719 & 8.5 & 8.9 & 9.2 & 8.6 & 35.2 \\
\hline $23: 10$ & 0 & 23.6 & 719 & 6.6 & 7.0 & 6.9 & 5.7 & 26.22 \\
\hline $01: 40$ & 0 & 24.9 & 844.5 & 9.5 & 9.0 & 8.2 & 7.2 & 33.9 \\
\hline $21: 50$ & 0 & 25.4 & 896 & 8.6 & 8.6 & 8.7 & 8.3 & 34.2 \\
\hline $22: 10$ & 0 & 26.1 & 972.5 & 5.3 & 4.9 & 5.3 & 5.6 & 21.15 \\
\hline $23: 20$ & 0 & 26.6 & 1029.5 & 5.2 & 5.3 & 4.7 & 4.6 & 19.78 \\
\hline $21: 40$ & 0 & 26.7 & 1041.2 & 8.7 & 9.0 & 8.9 & 8.2 & 34. \\
\hline $22: 20$ & 0 & 27.1 & 1088.7 & 5.5 & 5.3 & 5.6 & 5.5 & 21.9 \\
\hline $23: 50$ & 0 & 27.7 & 116 & 9.7 & 9.7 & 9.8 & 9.2 & 38. \\
\hline $23: 40$ & 0 & 29.1 & 1347.9 & 9.7 & 9.8 & 9.9 & 9.4 & 38. \\
\hline $00: 40$ & 0 & 29.2 & 136 & 9.7 & 9.8 & 9.6 & 8.9 & $3 \varepsilon$ \\
\hline $00: 50$ & 0 & 29.6 & 1418.6 & 9.7 & 9.8 & 9.7 & 8.5 & 37.7 \\
\hline Means: & (all) & 21.7 & 620.0 & 6.6 & 6.6 & 6.7 & 6.1 & 25.9 \\
\hline & norm & 21. 1 & 558.7 & 6.3 & 6.3 & 6.4 & 5.8 & 24.9 \\
\hline & low & 17.5 & 312.1 & 4.7 & 4.6 & 4.7 & 4.2 & 18.1 \\
\hline & middle & 21.7 & 563.1 & 7.3 & 7.5 & 7.6 & 6.9 & 29.3 \\
\hline & high & 26.4 & 1021.9 & 8.2 & 8.2 & 8.2 & 7.7 & 32.2 \\
\hline
\end{tabular}


Table 3-1.d Combined File, Souza-C Direct Wake Test Analys is

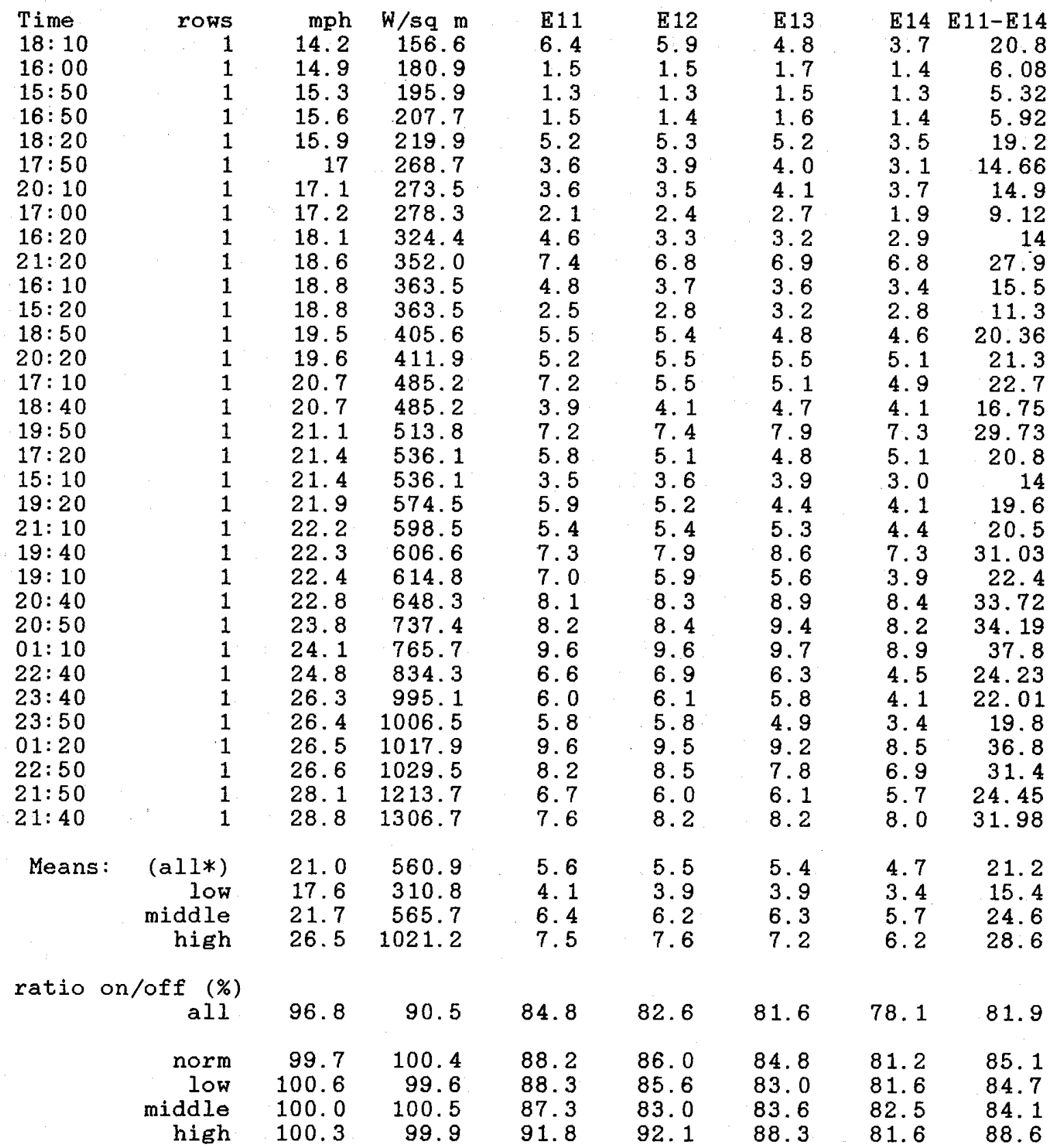

* Note: Wind directions less than 200 degrees eliminated. 


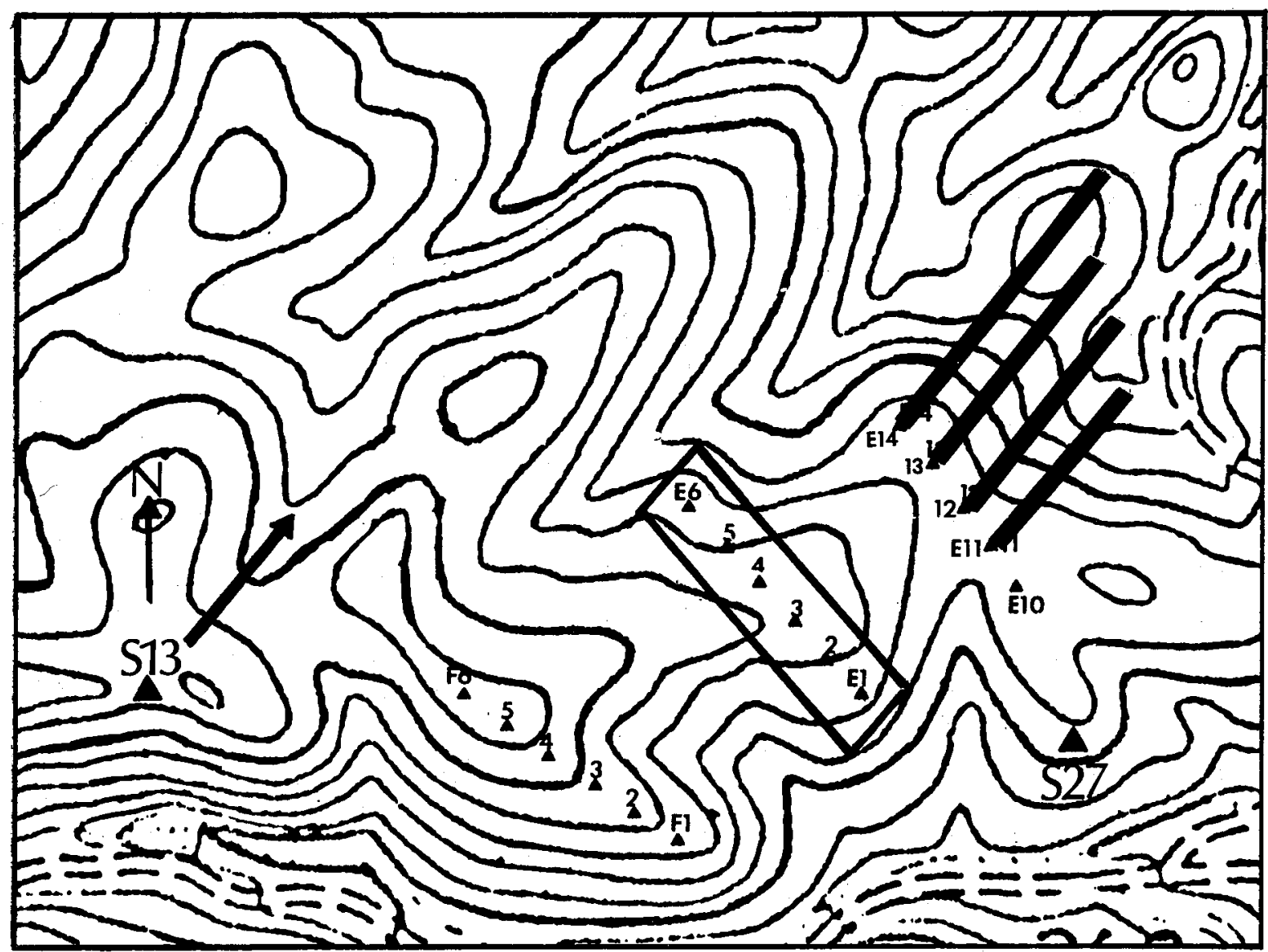

Figure 3-1.b. Souza-C Direct Wake Effect Tests Individual Turbine Deficits

Aug 7, Oct 1-2, 1987 test conditions at reference anemometer, S-13: mean speed $=21.1 \mathrm{mph}$, mean direction $=220$ degrees.

KEY

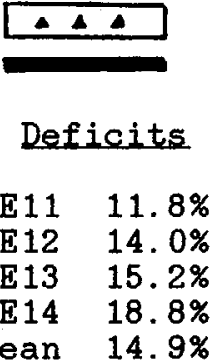

$=$ turbines switched on and off

$=\%$ wake energy deficit, $1^{\prime \prime}=10 \%$ 
Table 3-1.e Jess-C Direct Make Test Inalysis 1

POR RINDPABH: JBSS RAICB NIMBRABL

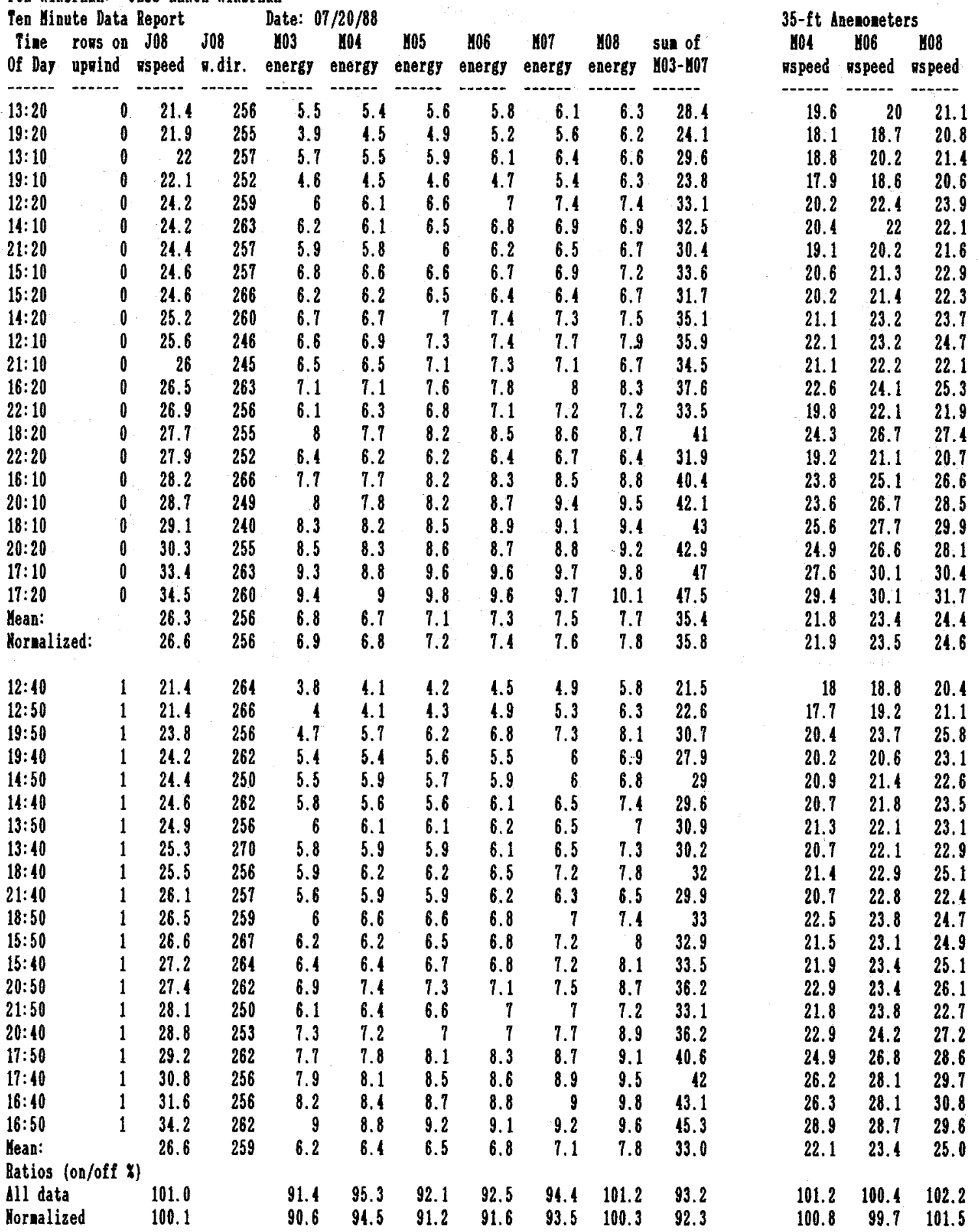


was calculated for the first test period. The second set of means is marked "normalized." The difference in mean speeds at J08, and presumably any bias, has been reduced.

The energy ratios between these two periods are 1 isted on the bottom of the page. The normalized ratios for the turbines ranged from $90.6 \%$ at M03 to $100.3 \%$ at M08. These ratios are equivalent to an energy deficit of $9.4 \%$ at M03, and an energy increase of $0.3 \%$ at M08. Because of the alignment of the array and the mean wind direction of 259 with turbines on, turbine M08 was not in the expected wake trajectory. The mean row deficit, excluding M08, was 7.7\%. These energy deficits are considerably lower than the previous test results, but the speeds in this test were quite a bit higher.

Wind speeds at the $35-\mathrm{ft}$ turbine anemometers are 1 isted in the three righthand columns of Table 3-1.e. The ratios at the bottom of the table show that there were no speed deficits at these sensors. These sensors are $11 \mathrm{ft}$ below the bottom of the rotor and presumably well below the wake centerline.

The statistical significance of the energy deficits of $7.7 \%$ for the row and $9.4 \%$ for M03 were 0.90 and 0.95 , respectively.

\subsubsection{Test 6 Analysis, Jess-C, Ju1y 21,1988}

Table 3-1.f is the data listing for the July 21, 1988 test on Jess-C. This test ended prematurely after $5 \mathrm{~h}$ because the winds dropped below cut-in speed at about 23:30. The table shows that the mean wind direction at J08 was 260 , almost westerly, with a mean speed of $26.1 \mathrm{mph}$. The mean speeds at the test turbines ranged from $21 \mathrm{mph}$ to $24 \mathrm{mph}$. The test turbine configuration was identical to the previous test.

The table shows that there was a substantial difference in mean speeds at the upwind reference anemometer between the two test periods; 26.2 mph versus $24.4 \mathrm{mph}$. A second set of means was calculated that had a mean speed of $26.1 \mathrm{mph}$ at J08. This "normalized" mean eliminated the first three records of the second data set.

The energy ratios at the bottom of the table for the normalized period ranged from $82.8 \%$ at M05 to $99.8 \%$ at M08. These are equivalent to energy deficits of $17.2 \%$ at MOS and $0.2 \%$ at M08. Because of the wind direction and array alignment, turbine M08 was out of the expected wake trajectory. The row mean deficit, which excluded M08, was $13.9 \%$.

The 35-ft wind speed data showed deficits of $3.4 \%$ at M04, $2.6 \%$ at M05, and $0.6 \%$ at M08.

These test results were quite different from the previous test at this array. The energy deficits were almost twice as high, even though the mean speed at J08 was only $0.5 \mathrm{mph}$ less than the first test. Considering the similarities in mean speeds at the upwind reference, the results were expected to be more consistent. However, the second test was much shorter, with only half the number of data points, and the normalizing process eliminated three more data points. These two tests will undergo additional analysis in the next section. 
Table 3-1.f Jess-C Direct Wake Test Analysis ?

POR YIMDPARY: JRSS BANCH YINDRARY

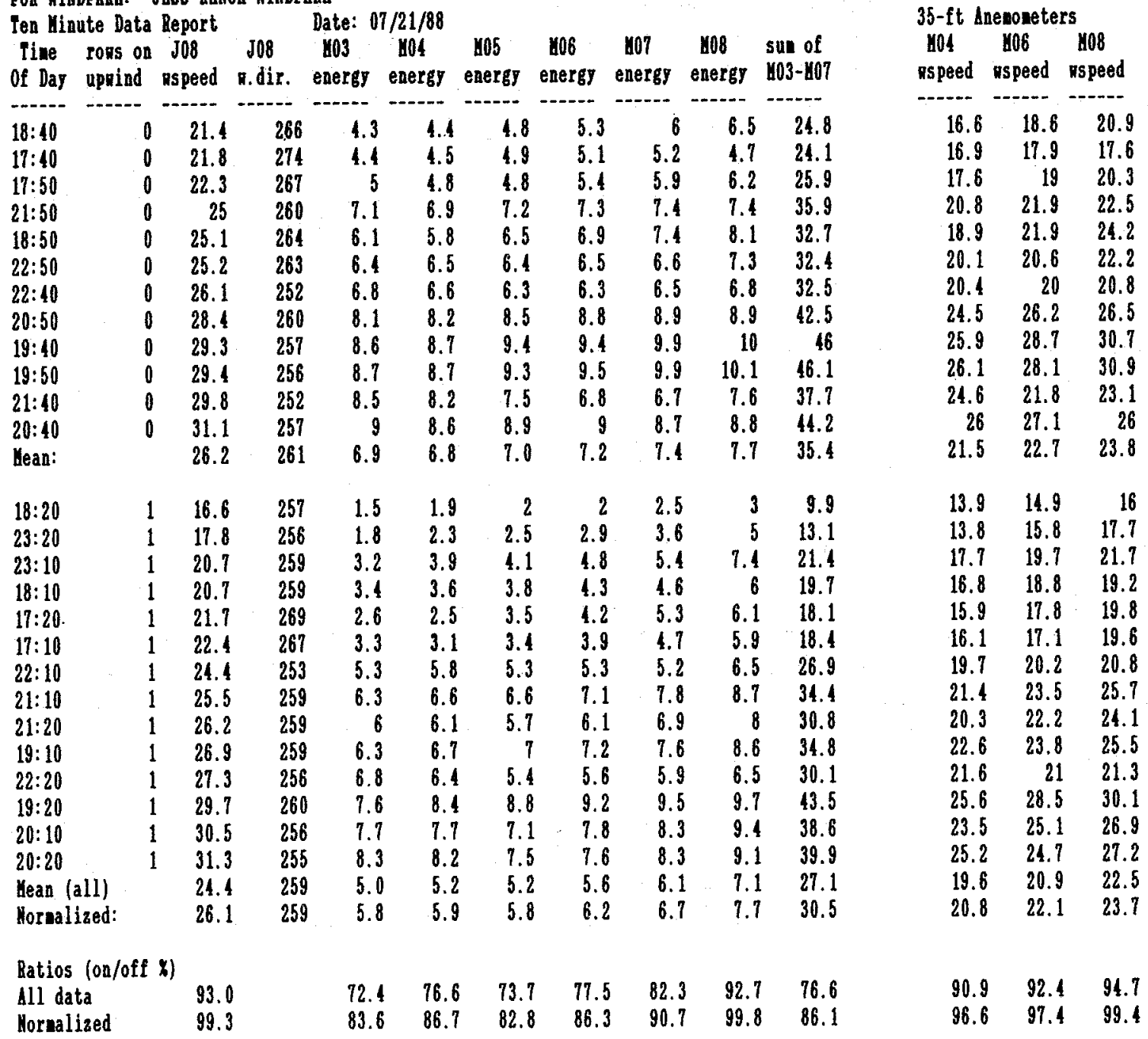


The statistical significance of the row energy deficit and individual turbine deficit at M05 was 0.90 and 0.95 , respectively.

\subsubsection{Jess-C Combined File}

The data from all three tests conducted in this array were combined and are listed in Table 3-1.g. Data from the aborted test conducted on July 18, 1988 were also included. The July 18 data are listed in Table $3-1 . h$. This test was aborted after $4 \mathrm{~h}$ because of high winds. Energy deficits for this brief test ranged from $0 \%$ to $3 \%$.

Table 3-1.g, the combined file, shows that wind speeds ranged from $16.6 \mathrm{mph}$ to $37.6 \mathrm{mph}$ at J08 with a mean speed of $27.8 \mathrm{mph}$. The mean wind direction was west-southwesterly to west.

There were no wind speed deficits at the 35-ft turbine anemometers, so these data are not included in this table. The data have been stratified by J08 wind speed into three subsets; winds above $30 \mathrm{mph}$, winds below $30 \mathrm{mph}$, and a low wind speed set. This low speed data set has the same mean speed as the 16-D tests that were conducted at this array and discussed in section 3.2 . There is also a subset stratified by wind direction, which excludes the records with wind directions greater than 265 .

Energy ratios were calculated for these data sets. The first ratio is for the entire data set, which had a mean speed of $27.8 \mathrm{mph}$. In this set and in all the subsets, M08 had negligible deficits and was not included in the row means. The row energy deficit for this data set was $7.9 \%$, and M03 had the highest deficit, $10.1 \%$. The second set of ratios is for the wind directions less than 265. The deficits increased by about $1.5 \%$ at all turbines. This increase was a result of better alignment with the test array and not of a wind speed change. The next two ratios are for winds below and above $30 \mathrm{mph}$. The mean speeds for these two data sets were $24.8 \mathrm{mph}$ and $33.1 \mathrm{mph}$. The energy deficits for these two sets were $10.6 \%$ and $3.8 \%$, respectively. The last set of ratios is for low winds and consists of the lower one-third of the observations. This subset had a mean speed of $22.7 \mathrm{mph}$ and a mean deficit of $12.7 \%$. The last three sets of ratios illustrate the inverse relationship between wind speed and energy deficits.

The low speed subset (1ast set) is especially useful because it can be compared to results of the 16-D tests in Section 3.2. Data from this low-speed subset have been plotted on Figure 3-1.c. This is a topographic map with bars plotted, showing the magnitude of the individual turbine deficits. It is similar to Figures $3-1 . a$ and $3-1 . b$.

\subsubsection{Summary}

Six direct wake effect tests were conducted on the Jess and Souza Ranches. Spacing between test rows varied from $6.8 \mathrm{D}$ at Souza-C to $9.5 \mathrm{D}$ at Jess-A. Row deficits varied from $3.8 \%$ in $33.0-\mathrm{mph}$ winds to $16.1 \%$ in 20.1 -mph winds. Individual turbine deficits ranged from $0.0 \%$ to $25.7 \%$. Analysis of the individual tests showed that wind speed, thrust coefficient ( $C t$ ), and system coefficient of power ( $C_{p}$ ) were variables that were highly correlated to the magnitude of the deficits. Wind direction is important too, because there were little or no wake deficits at turbines outside the expected wake trajectory. 
Table 3-1.g Combined File, Jess-C Direct Wake Test Analysis

FOR WINDFARM: JESS RANCH WINDFARM

DATE:

Ten Minute Data Report

$\begin{array}{lllllllll}\text { Time rows on J08 } & \text { J08 } & \text { M03 } & \text { M04 } & \text { M05 } & \text { M06 } & \text { M07 } & \text { M08 } & \text { sum of }\end{array}$

Of Day upwind wspeed w.dir. energy energy energy energy energy energy M03-M07

\begin{tabular}{|c|c|c|c|c|c|c|c|c|c|c|}
\hline $18: 40$ & 0 & 21.4 & 260 & 4.3 & 4.4 & 4.8 & 5.3 & 6.0 & 6.5 & 24.8 \\
\hline $13: 20$ & 0 & 21.4 & 252 & 5.5 & 5.4 & 5.6 & 5.8 & 6.1 & 6.3 & 28.4 \\
\hline $17: 40$ & 0 & 21.8 & 252 & 4.4 & 4.5 & 4.9 & 5.1 & 5.2 & 4.7 & 24.1 \\
\hline $19: 20$ & 0 & 21.9 & 262 & 3.9 & 4.5 & 4.9 & 5.2 & 5.6 & 6.2 & 24.1 \\
\hline $13: 10$ & 0 & 22.0 & 256 & 5.7 & 5.5 & 5.9 & 6.1 & 6.4 & 6.6 & 29.6 \\
\hline $19: 10$ & 0 & 22.1 & 243 & 4.6 & 4.5 & 4.6 & 4.7 & 5.4 & 6.3 & 23.8 \\
\hline $17: 50$ & 0 & 22.3 & 255 & 5.0 & 4.8 & 4.8 & 5.4 & 5.9 & 6.2 & 25.9 \\
\hline $14: 10$ & 0 & 24.2 & 249 & 6.2 & 6.1 & 6.5 & 6.8 & 6.9 & 6.9 & 32.5 \\
\hline $12: 20$ & 0 & 24.2 & 246 & 6.0 & 6.1 & 6.6 & 7.0 & 7.4 & 7.4 & 33.1 \\
\hline $21: 20$ & 0 & 24.4 & 243 & 5.9 & 5.8 & 6.0 & 6.2 & 6.5 & 6.7 & 30.4 \\
\hline $15: 20$ & 0 & 24.6 & 243 & 6.2 & 6.2 & 6.5 & 6.4 & 6.4 & 6.7 & 31.7 \\
\hline $15: 10$ & 0 & 24.6 & 253 & 6.8 & 6.6 & 6.6 & 6.7 & 6.9 & 7.2 & 33.6 \\
\hline $21: 50$ & 0 & 25.0 & 253 & 7.1 & 6.9 & 7.2 & 7.3 & 7.4 & 7.4 & 35.9 \\
\hline $18: 50$ & 0 & 25.1 & 248 & 6.1 & 5.8 & 6.5 & 6.9 & 7.4 & 8.1 & 32.7 \\
\hline $14: 20$ & 0 & 25.2 & 257 & 6.7 & 6.7 & 7.0 & 7.4 & 7.3 & 7.5 & 35.1 \\
\hline $22: 50$ & 0 & 25.2 & 250 & 6.4 & 6.5 & 6.4 & 6.5 & 6.6 & 7.3 & 32.4 \\
\hline $12: 10$ & 0 & 25.6 & 250 & 6.6 & 6.9 & 7.3 & 7.4 & 7.7 & 7.9 & 35.9 \\
\hline $21: 10$ & 0 & 26.0 & 248 & 6.5 & 6.5 & 7.1 & 7.3 & 7.1 & 6.7 & 34.5 \\
\hline $22: 40$ & 0 & 26.1 & 242 & 6.8 & 6.6 & 6.3 & 6.3 & 6.5 & 6.8 & 32.5 \\
\hline $16: 20$ & 0 & 26.5 & 256 & 7.1 & 7.1 & 7.6 & 7.8 & 8.0 & 8.3 & 37.6 \\
\hline $22: 10$ & 0 & 26.9 & 255 & 6.1 & 6.3 & 6.8 & 7.1 & 7.2 & 7.2 & 33.5 \\
\hline $18: 10$ & 0 & 26.9 & 257 & 7.6 & 7.5 & 8.3 & 8.6 & 8.4 & 8.7 & 40.4 \\
\hline $18: 00$ & 0 & 27.1 & 252 & 7.7 & 7.5 & 7.9 & 7.7 & 7.8 & 8.0 & 38.6 \\
\hline $18: 20$ & 0 & 27.7 & 259 & 8.0 & 7.7 & 8.2 & 8.5 & 8.6 & 8.7 & 41.0 \\
\hline $22: 20$ & 0 & 27.9 & 263 & 6.4 & 6.2 & 6.2 & 6.4 & 6.7 & 6.4 & 31.9 \\
\hline $16: 10$ & 0 & 28.2 & 257 & 7.7 & 7.7 & 8.2 & 8.3 & 8.5 & 8.8 & 40.4 \\
\hline $20: 50$ & 0 & 28.4 & 257 & 8.1 & 8.2 & 8.5 & 8.8 & 8.9 & 8.9 & 42.5 \\
\hline $20: 10$ & 0 & 28.7 & 266 & 8.0 & 7.8 & 8.2 & 8.7 & 9.4 & 9.5 & 42.1 \\
\hline $18: 10$ & 0 & 29.1 & 260 & 8.3 & 8.2 & 8.5 & 8.9 & 9.1 & 9.4 & 43.0 \\
\hline $19: 40$ & 0 & 29.3 & 246 & 8.6 & 8.7 & 9.4 & 9.4 & 9.9 & 10.0 & 46.0 \\
\hline $19: 50$ & 0 & 29.4 & 245 & 8.7 & 8.7 & 9.3 & 9.5 & 9.9 & 10.1 & 46.1 \\
\hline 21: 40 & 0 & 29.8 & 263 & 8.5 & 8.2 & 7.5 & 6.8 & 6.7 & 7.6 & 37.7 \\
\hline $20: 10$ & 0 & 30.2 & 256 & 8.6 & 8.3 & 8.5 & 8.3 & 8.5 & 8.7 & 42.2 \\
\hline $20: 20$ & 0 & 30.3 & 255 & 8.5 & 8.3 & 8.6 & 8.7 & 8.8 & 9.2 & 42.9 \\
\hline $18: 20$ & 0 & 30.8 & 252 & 8.7 & 8.6 & 9.2 & 9.0 & 9.3 & 9.3 & 44.8 \\
\hline $20: 40$ & 0 & 31. 1 & 266 & 9.0 & 8.6 & 8.9 & 9.0 & 8.7 & 8.8 & 44.2 \\
\hline $19: 20$ & 0 & 31.7 & 249 & 9.0 & 8.7 & 9.0 & 9.0 & 9.4 & 9.8 & 45.1 \\
\hline $20: 20$ & 0 & 31.9 & 240 & 8.9 & 8.5 & 9.0 & 9.2 & 9.3 & 9.0 & 44.9 \\
\hline $17: 10$ & 0 & 33.4 & 255 & 9.3 & 8.8 & 9.6 & 9.6 & 9.7 & 9.8 & 47.0 \\
\hline $19: 10$ & 0 & 33.9 & 263 & 9.2 & 8.9 & 9.4 & 9.6 & 9.6 & 10.1 & 46.7 \\
\hline $17: 20$ & 0 & 34.5 & 260 & 9.4 & 9.0 & 9.8 & 9.6 & 9.7 & 10.1 & 47.5 \\
\hline $22: 20$ & 0 & 35.4 & 264 & 9.5 & 8.9 & 9.0 & 9.5 & 9.5 & 9.5 & 46.4 \\
\hline $21: 10$ & 0 & 35.6 & 266 & 9.3 & 9.0 & 10.1 & 9.9 & 10.2 & 10.4 & 48.5 \\
\hline $21: 20$ & 0 & 35.7 & 256 & 9.5 & 9.3 & 10.2 & 9.9 & 10.2 & 10.5 & 49.1 \\
\hline $22: 10$ & Q & 37,4 & 262 & 9.6 & 9.1 & 9.5 & 9.7 & 9.7 & 9.9 & 47.6 \\
\hline Means: & & 27.8 & 254 & 7.3 & 7.2 & 7.6 & $\overline{7.7}$ & $\overline{7.9}$ & 8.1 & 37.7 \\
\hline Winds $<30 \mathrm{mph}$ & & 24.8 & 252 & 6.2 & 6.2 & 6.5 & 6.7 & 6.9 & 7.1 & 32.5 \\
\hline Winds $>30 \mathrm{mph}$ & & 33.2 & 257 & 9.1 & 8.8 & 9.3 & 9.3 & 9.4 & 9.6 & 45.9 \\
\hline Low Winds & & 22.8 & 251 & 5.2 & 5.3 & 5.6 & 5.8 & 6.2 & 6.4 & 28.0 \\
\hline
\end{tabular}


Table 3-1.g Combined File, Jess-C Direct Wake Test Analysis

\begin{tabular}{|c|c|c|c|c|c|c|c|c|c|c|}
\hline rows 0 & & J08 พธ & $\mathrm{J} 08 \mathrm{wd}$ & M03 & MO4 & M05 & M06 & M07 & M08 & M03-M07 \\
\hline $18: 20$ & 1 & 16.6 & 250 & 1.5 & 1.9 & 2.0 & 2.0 & 2.5 & 3.0 & 9.9 \\
\hline $23: 20$ & 1 & 17.8 & 262 & 1.8 & 2.3 & 2.5 & 2.9 & 3.6 & 5.0 & 13.1 \\
\hline $18: 10$ & 1 & 20.7 & 256 & 3.4 & 3.6 & 3.8 & 4.3 & 4.6 & 6.0 & 19.7 \\
\hline $23: 10$ & 1 & 20.7 & 270 & 3.2 & 3.9 & 4.1 & 4.8 & 5.4 & 7.4 & 21.4 \\
\hline $12: 40$ & 1 & 21.4 & 256 & 3.8 & 4.1 & 4.2 & 4.5 & 4.9 & 5.8 & 21.5 \\
\hline $12: 50$ & 1 & 21.4 & 257 & 4.0 & 4.1 & 4.3 & 4.9 & 5.3 & 6.3 & 22.6 \\
\hline $17: 20$ & 1 & 21.7 & 259 & 2.6 & 2.5 & 3.5 & 4.2 & 5.3 & 6.1 & 18.1 \\
\hline $17: 10$ & 1 & 22.4 & 267 & 3.3 & 3.1 & 3.4 & 3.9 & 4.7 & 5.9 & 18.4 \\
\hline $19: 50$ & 1 & 23.8 & 264 & 4.7 & 5.7 & 6.2 & 6.8 & 7.3 & 8.1 & 30.7 \\
\hline $19: 40$ & 1 & 24.2 & 262 & 5.4 & 5.4 & 5.6 & 5.5 & 6.0 & 6.9 & 27.9 \\
\hline $22: 10$ & 1 & 24.4 & 250 & 5.3 & 5.8 & 5.3 & 5.3 & 5.2 & 6.5 & 26.9 \\
\hline $14: 50$ & 1 & 24.4 & 253 & 5.5 & 5.9 & 5.7 & 5.9 & 6.0 & 6.8 & 29.0 \\
\hline $14: 40$ & 1 & 24.6 & 262 & 5.8 & 5.6 & 5.6 & 6.1 & 6.5 & 7.4 & 29.6 \\
\hline $13: 50$ & 1 & 24.9 & 256 & 6.0 & 6.1 & 6.1 & 6.2 & 6.5 & 7.0 & 30.9 \\
\hline $13: 40$ & 1 & 25.3 & 256 & 5.8 & $5 . \overline{9}$ & 5.9 & 6.1 & 6.5 & 7.3 & 30.2 \\
\hline $21: 10$ & 1 & 25.5 & 262 & 6.3 & 6.6 & 6.6 & 7.1 & 7.8 & 8.7 & 34.4 \\
\hline $18: 40$ & 1 & 25.5 & 266 & 5.9 & 6.2 & 6.2 & 6.5 & 7.2 & 7.8 & 32.0 \\
\hline $21: 40$ & 1 & 26. 1 & 274 & 5.6 & 5.9 & 5.9 & 6.2 & 6.3 & 6.5 & 29.9 \\
\hline $21: 20$ & 1 & 26.2 & 267 & 6.0 & 6.1 & 5.7 & 6.1 & 6.9 & 8.0 & 30.8 \\
\hline $18: 50$ & 1 & 26.5 & 260 & 6.0 & 6.6 & 6.6 & 6.8 & 7.0 & 7.4 & 33.0 \\
\hline $15: 50$ & 1 & 26.6 & 264 & 6.2 & 6.2 & 6.5 & 6.8 & 7.2 & 8.0 & 32.9 \\
\hline $19: 10$ & 1 & 26.9 & 263 & 6.3 & 6.7 & 7.0 & 7.2 & 7.6 & 8.6 & 34.8 \\
\hline $15: 40$ & 1 & 27.2 & 252 & 6.4 & 6.4 & 6.7 & 6.8 & 7.2 & 8.1 & 33.5 \\
\hline $22: 20$ & 1 & 27.3 & 260 & 6.8 & 6.4 & 5.4 & 5.6 & 5.9 & 6.5 & 30.1 \\
\hline $20: 50$ & 1 & 27.4 & 257 & 6.9 & 7.4 & 7.3 & 7.1 & 7.5 & 8.7 & 36.2 \\
\hline $21: 50$ & 1 & 28.1 & 256 & 6.1 & 6.4 & 6.6 & 7.0 & 7.0 & 7.2 & 33.1 \\
\hline $20: 40$ & 1 & 28.8 & 252 & 7.3 & 7.2 & 7.0 & 7.0 & 7.7 & 8.9 & 36.2 \\
\hline $17: 50$ & 1 & 29.2 & 257 & 7.7 & 7.8 & 8.1 & 8.3 & 8.7 & 9.1 & 40.6 \\
\hline $18: 40$ & 1 & 29.5 & 257 & 7.7 & 7.6 & 8.0 & 8.4 & 8.6 & 9.1 & 40.3 \\
\hline $19: 20$ & 1 & 29.7 & 256 & 7.6 & 8.4 & 8.8 & 9.2 & 9.5 & 9.7 & 43.5 \\
\hline $19: 40$ & 1 & 30.3 & 259 & 8.2 & 8.0 & 8.3 & 8.4 & 8.8 & 9.0 & 41.7 \\
\hline $20: 10$ & 1 & 30.5 & 259 & 7.7 & 7.7 & 7.1 & 7.8 & 8.3 & 9.4 & 38.6 \\
\hline $19: 50$ & 1 & 30.6 & 269 & 8.1 & 7.6 & 7.9 & 8.4 & 8.7 & 8.4 & 40.7 \\
\hline $17: 40$ & 1 & 30.8 & 267 & 7.9 & 8.1 & 8.5 & 8.6 & 8.9 & 9.5 & 42.0 \\
\hline $20: 20$ & 1 & 31.3 & 253 & 8.3 & 8.2 & 7.5 & 7.6 & 8.3 & 9.1 & 39.9 \\
\hline $16: 40$ & 1 & 31.6 & 259 & 8.2 & 8.4 & 8.7 & 8.8 & 9.0 & 9.8 & 43.1 \\
\hline $18: 50$ & 1 & 32.6 & 259 & 8.4 & 8.5 & 9.2 & 9.4 & 9.5 & 9.7 & 45.0 \\
\hline $16: 50$ & 1 & 34.2 & 259 & 9.0 & 8.8 & 9.2 & 9.1 & 9.2 & 9.6 & 45.3 \\
\hline $20: 40$ & 1 & 34.4 & 256 & 9.4 & 8.8 & 9.2 & 9.6 & 9.7 & 9.8 & 46.7 \\
\hline $21: 50$ & 1 & 35.3 & 260 & 9.0 & 8.9 & 9.7 & 9.8 & 10.1 & 10.4 & 47.5 \\
\hline $20: 50$ & 1 & 35.4 & 256 & 9.2 & 8.9 & 9.5 & 9.8 & 10.0 & 10.3 & 47.4 \\
\hline $21: 40$ & 1 & 37.6 & 255 & 9.6 & 9.3 & 10.3 & 10.0 & 10.3 & 10.5 & 49.5 \\
\hline Means: & & & & & & & & & & \\
\hline All data & & 27.8 & 260 & 6.6 & 6.7 & 6.9 & 7.1 & 7.5 & 8.2 & 34.8 \\
\hline Winds $<30 \mathrm{mph}$ & & 24.8 & 259 & 5.4 & 5.6 & 5.7 & 6.0 & 6.4 & 7.3 & 29.0 \\
\hline Winds $>30 \mathrm{mph}$ & & 33.1 & 259 & 8.6 & 8.5 & 8.8 & 9.0 & 9.3 & 9.7 & 44.2 \\
\hline Low winds & & 22.7 & 259 & 4.4 & 4.6 & 4.8 & 5.1 & 5.6 & 6.6 & 24.5 \\
\hline Ratios (on/off & $\%)$ & & & & & & & & & \\
\hline Al1 data: & & 100.0 & & 89.9 & 93.0 & 90.5 & 92.2 & 94.7 & 100.6 & 92.1 \\
\hline WDK265 deg & & 100.0 & & 88.2 & 91.4 & 89.5 & 90.8 & 93.3 & 99.7 & 90.7 \\
\hline Winds $<30 \mathrm{mph}$ & & 100.2 & & 86.5 & 90.7 & 87.6 & 89.3 & 92.7 & 101.8 & 89.4 \\
\hline Winds $>30 \mathrm{mph}$ & & 99.7 & & 94.5 & 96.6 & 94.7 & 96.6 & 98.3 & 100.6 & 96.2 \\
\hline Low Winds & & 99.6 & & 83.3 & 88.1 & 85.8 & 88.0 & 91.0 & 102.8 & 87.3 \\
\hline
\end{tabular}


Table 3-1.h Jess-C Direct Hake fest Analysis (Aborted fest)

POR HINDPABH: JBSS BAHCH NIMDPARH

Dats:

$07 / 18 / 88$

Ten Uinute Data Report

Tive rops on J08 J08 $403 \quad 404 \quad 405 \quad 406 \quad 607$ y08 sun of Of Day uprind rspeed r.dir. energy energy energy energy energy energy 103-y07

\begin{tabular}{|c|c|c|c|c|c|c|c|c|c|c|c|c|c|}
\hline $\begin{array}{l}\text { Tine } \\
\text { of Day }\end{array}$ & $\begin{array}{l}\text { rons on } \\
\text { uprind }\end{array}$ & $\begin{array}{c}\text { J08 } \\
\text { nspeed }\end{array}$ & $\begin{array}{c}\text { J08 } \\
\text { q. dir. }\end{array}$ & $\begin{array}{c}103 \\
\text { energy }\end{array}$ & $\begin{array}{l}104 \\
\text { energy }\end{array}$ & $\begin{array}{l}1005 \\
\text { energy }\end{array}$ & $\begin{array}{c}506 \\
\text { energy }\end{array}$ & $\begin{array}{c}807 \\
\text { energy }\end{array}$ & $\begin{array}{c}\text { yob } \\
\text { energy }\end{array}$ & $\begin{array}{l}\text { sun of } \\
\text { s03-607 }\end{array}$ & $\begin{array}{l}\text { HO4 } \\
\text { us peed }\end{array}$ & $\begin{array}{c}\text { Y06 } \\
\text { uspeed }\end{array}$ & $\begin{array}{c}\text { y08 } \\
\text { uspeed }\end{array}$ \\
\hline $18: 10$ & 0 & 26.9 & 260 & 7.6 & 7.5 & 8.3 & 8.6 & 8.4 & 8.7 & 60.4 & 23.6 & 25.9 & 26.8 \\
\hline $18: 00$ & 0 & 27.1 & 252 & 7.7 & 7.5 & 7.9 & 7.7 & 7.8 & 8 & 38.6 & 23.2 & 24 & 25.2 \\
\hline $20: 10$ & 0 & 30.2 & 252 & 8.6 & 8.3 & 8.5 & 8.3 & 8.5 & 8.7 & 42.2 & 25.6 & 24.9 & 26.3 \\
\hline $18: 20$ & 0 & 30.8 & 262 & 8.7 & 8.6 & 9.2 & 9 & 9.3 & 9.3 & 44.8 & 27.2 & 27.6 & 28.8 \\
\hline $19: 20$ & 0 & 31.7 & 256 & 9 & 8.7 & 9 & 9 & 9.1 & 9.8 & 45.1 & 28.1 & 27.9 & 32.4 \\
\hline $20: 20$ & 0 & 31.9 & 243 & 8.9 & 8.5 & $g$ & 9.2 & 9.3 & 9 & 44.9 & 26.7 & 28.1 & 27.6 \\
\hline $19: 10$ & 0 & 33.9 & 255 & 9.2 & 8.9 & 9.4 & 9.6 & 9.6 & 10.1 & 46.7 & 29.1 & 29.7 & 33.3 \\
\hline $22: 20$ & 0 & 35.4 & 249 & 9.5 & 8.9 & 9 & 9.5 & 9.5 & 9.5 & 46.4 & 29.4 & 30.2 & 31 \\
\hline $21: 10$ & 0 & 35.6 & 246 & 9.3 & 9 & 10.1 & 9.9 & 10.2 & 10.4 & 48.5 & 29.6 & 32.6 & 35.2 \\
\hline $21: 20$ & 0 & 35.7 & 243 & 9.5 & 9.3 & 10.2 & 9.9 & 10.2 & 10.5 & 49.1 & 31.1 & 32.5 & 35.6 \\
\hline $22: 10$ & 0 & 37.4 & 243 & 9.6 & 9.1 & 9.5 & 9.7 & 9.7 & 9,9 & 17.6 & 30.6 & 31.4 & 32.4 \\
\hline Hean: & & 32.4 & 251 & 8.9 & 8.6 & 9.1 & 9.1 & 9.3 & 9.1 & 44.9 & 27.7 & 28.6 & 30.4 \\
\hline
\end{tabular}

\begin{tabular}{|c|c|c|c|c|c|c|c|c|c|c|c|c|c|}
\hline $18: 40$ & 1 & 29.5 & 253 & 7.7 & 7.6 & 8 & 8.4 & 8.6 & 9.1 & 40.3 & 25.2 & 27.4 & 29.9 \\
\hline $19: 40$ & 1 & 30.3 & 253 & 8.2 & 8 & 8.3 & 8.1 & 8.8 & 9 & 41.7 & 26.6 & 26.3 & 27.7 \\
\hline $19: 50$ & 1 & 30.6 & 248 & 8.1 & 7.6 & 7.9 & 8.4 & 8.7 & 8.4 & 40.7 & 24.9 & 26.9 & 25.8 \\
\hline $18: 50$ & 1 & 32.6 & 257 & 8.1 & 8.5 & 9.2 & 9.1 & 9.5 & 9.7 & 45 & 28.5 & 30.8 & 32.7 \\
\hline $20: 40$ & 1 & 34.4 & 250 & 9.4 & 8.8 & 9.2 & 9.6 & 9.7 & 9.8 & 46.7 & 29.2 & 30.8 & 31.9 \\
\hline $21: 50$ & 1 & 35.3 & 250 & 9 & 8.9 & 9.7 & 9.8 & 10.1 & 10.1 & 17.5 & 30.6 & 32.2 & 34.9 \\
\hline $20: 50$ & 1 & 35.4 & 248 & 9.2 & 8.9 & 9.5 & 9.8 & 10 & 10.3 & 47.4 & 29.5 & 31.9 & 34.1 \\
\hline $21: 40$ & 1 & 37.6 & 242 & 9.6 & 9.3 & 10.3 & 10 & 10.3 & 10.5 & 49.5 & 32 & 34.1 & 37.4 \\
\hline Hean (all). & & 33.2 & 250 & 8.7 & 8.5 & 9.0 & 9.2 & 9.5 & 9.7 & 44.9 & 28.3 & 30.1 & 31.8 \\
\hline Nornalized: & & 32.6 & 251 & 8.6 & 8.3 & 8.8 & 9.1 & 9.3 & 9.5 & 44.2 & 27.8 & 29.5 & 31.0 \\
\hline
\end{tabular}

Ratios (on/off $x$ )

All data $\quad 102.5$

Noralized $\quad 100.5$ $\begin{array}{lllllll}98.1 & 98.6 & 99.0 & 101.1 & 102.1 & 102.2 & 99.8\end{array}$ $\begin{array}{lllllll}96.6 & 97.2 & 97.0 & 99.9 & 100.9 & 100.9 & 98.3\end{array}$
$102.4 \quad 105.0 \quad 104.5$ $100.5 \quad 103.0 \quad 101.9$ 


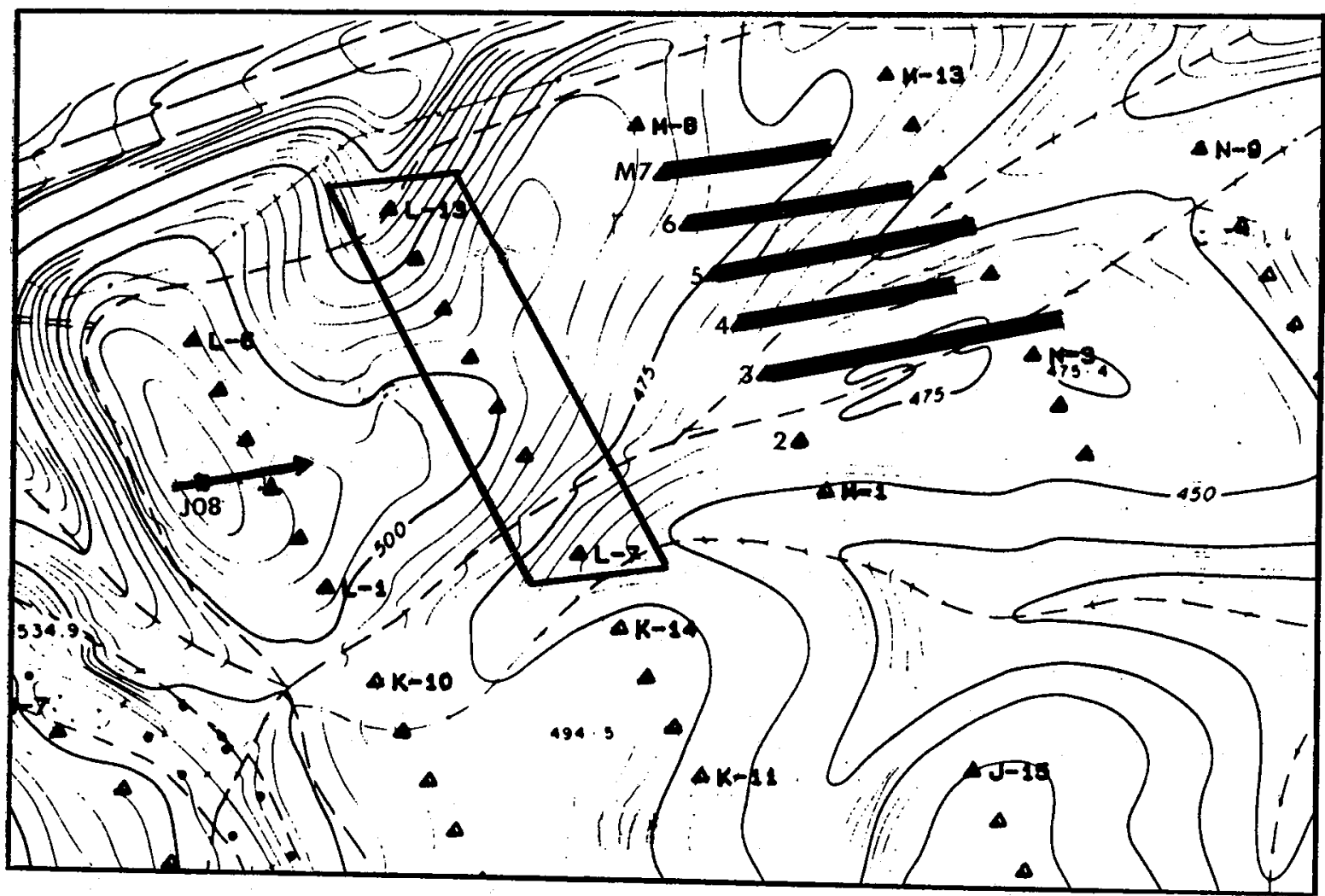

\section{Figure 3-1.c. Jess-C Direct Wake Effect Tests Individual Turbine Deficits (Low-s peed Sub-set)}

July 18-21, 1988 test conditions at reference anemometer, J-08: mean speed $=22.7 \mathrm{mph}$, mean direction $=259$ degrees.

KEY

A. $A$

$=$ turbines switched on and off

$=\%$ wake energy deficit, $1 "=10 \%$

Deficits

$\begin{array}{rr}\text { M3 } & 16.7 \% \\ \text { M4 } & 11.9 \% \\ \text { M5 } & 14.2 \% \\ \text { M6 } & 12.0 \% \\ \text { M7 } & 9.0 \% \\ \text { M3-M7 } & 12.7 \%\end{array}$


To illustrate the relationship between speed and energy deficits, the mean row deficits and maximum individual turbine deficits from each test have been plotted as a function of wind speed. The deficits from the stratified subsets of the combined files have also been plotted. Figure $3-1 . d$ shows the relationship between wind speed and wake deficits. The $x$-axis is wind speed. The wind speed at the reference anemometer was used in most cases, except when the turbine anemometers showed that there was a large difference between the reference and the turbines, notably at Jess-A. In this case, the 35-ft turbine anemometers' speeds were used, adjusted to hub-height using a vertical shear exponent, alpha, of 0.14 . Although the free-flow data showed that alphas were slightly lower than this, long-term measurements with wakes present show that 0.14 is an appropriate number.

The mean row deficits are plotted as squares and the maximum individual deficits as diamonds. Two lines of best fit have been analyzed by hand on the figure. The best-fit lines show the inverse relationship between wind speed and energy deficits. The correlation coefficient between these two variables was quite good at -0.92 . Thus, $85 \%$ of the variability in the energy deficits was explained by wind speed variation. The best-fit line for the maximum individual turbine is slightly steeper, but the correlation coefficient is also -0.92 . The mean row deficit line intercepts zero at about $35 \mathrm{mph}$. Figure $2-3$, the Nordtank power curve, shows that the turbine reaches its rated output of $65 \mathrm{~kW}$ near this speed. Regression analysis shows that the slope of this best-fit line is -0.8 . The inverse relationship between speed and deficit is very similar to findings by Simon (1986) and D. L. E11iott et al. (1988). There is some scatter about the best-fit lines, which could be caused by different spacing between rows, different terrain, and varying levels of atmospheric stability and turbulence.

The inverse relationship was responsible for much of the variation in individual turbine deficits within the test rows. Turbines at lower elevation sites often had lower energy output (lower winds) and higher energy deficits. No attempt has been made to try to normalize these terrain effects on wake deficits. There is no prescribed methodology for this exercise, or any purpose.

Recall from the discussion of the Nordtank turbine, in Section 2.2.3, that wind speed and $C t$ had a near-perfect inverse correlation. Because of this near-perfect correlation, these two variables are suitable surrogates for each other. The inverse correlation between wake deficits and wind speed discussed above was essentially the same in magnitude as the correlation between energy deficits and $\mathrm{Ct}$. However, this correlation was positive at 0.91 . The best correlation, 0.94 , was obtained between energy deficits and $C_{p}$. The three parameters; wind speed, $\mathrm{Cp}_{\mathrm{p}}$, and $\mathrm{Ct}$, are interrelated. The wake deficits were a function of a combination of wind speed and turbine performance.

Figures 3.1.e and 3.1.f show the relationship between the mean row energy deficits and $\mathrm{Cp}$ and $\mathrm{Ct}$. The mean row deficits are plotted as squares and the best-fit lines have also been plotted. The correlation coefficients $(r)$ are plotted in the lower left corner.

Statistical significance of the mean row energy deficits was 0.90 in four of the tests and 0.80 in one. Statistical significance of the maximum individual turbine deficits ranged from 0.80 to 0.99 and was about 0.05 higher than the mean row deficits. 


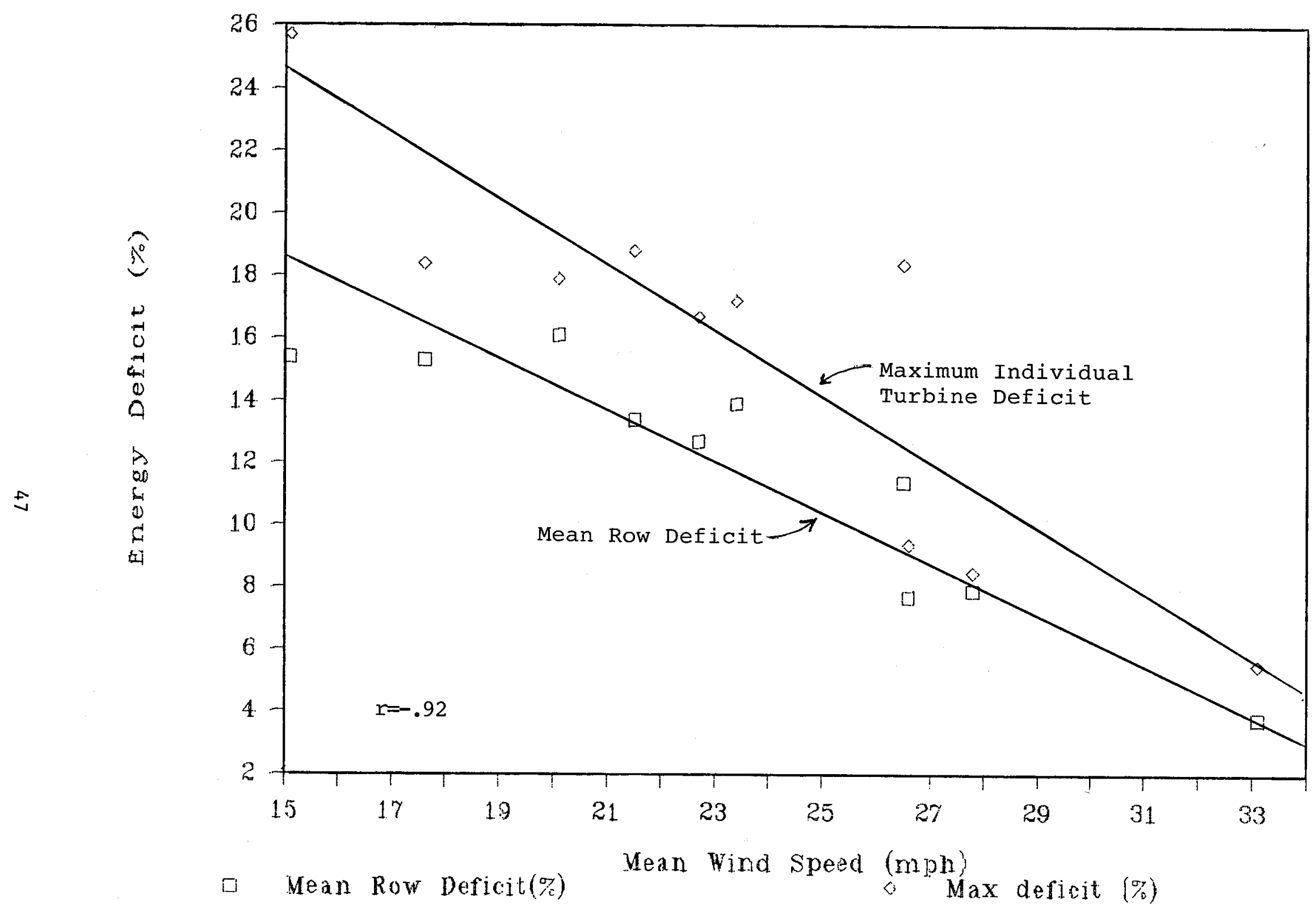

Figure 3-1.d. Wake Deficits (z) vs. Mean Wind speed 


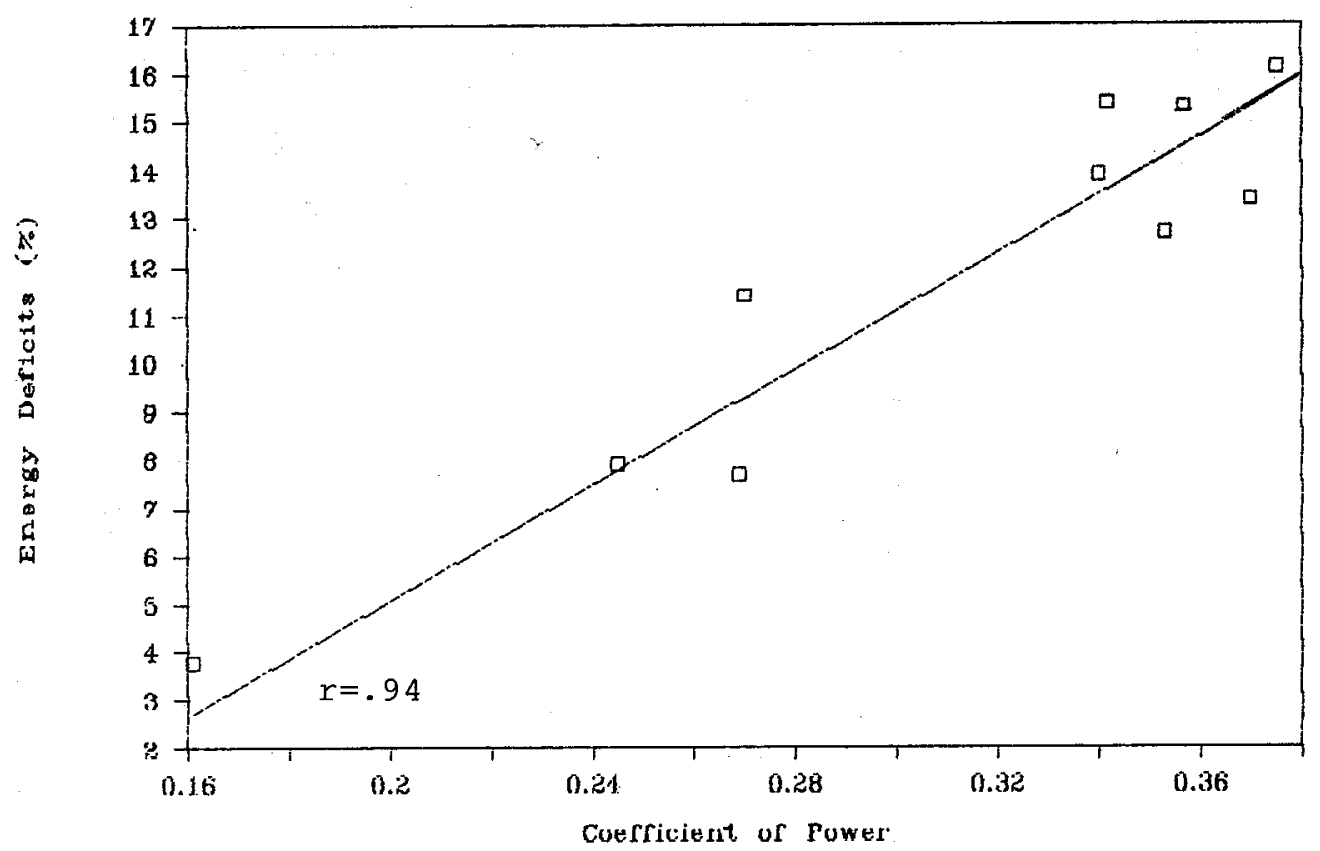

Figure 3-1.e. Wake Deficits (\%) vs. Coefficient of Power

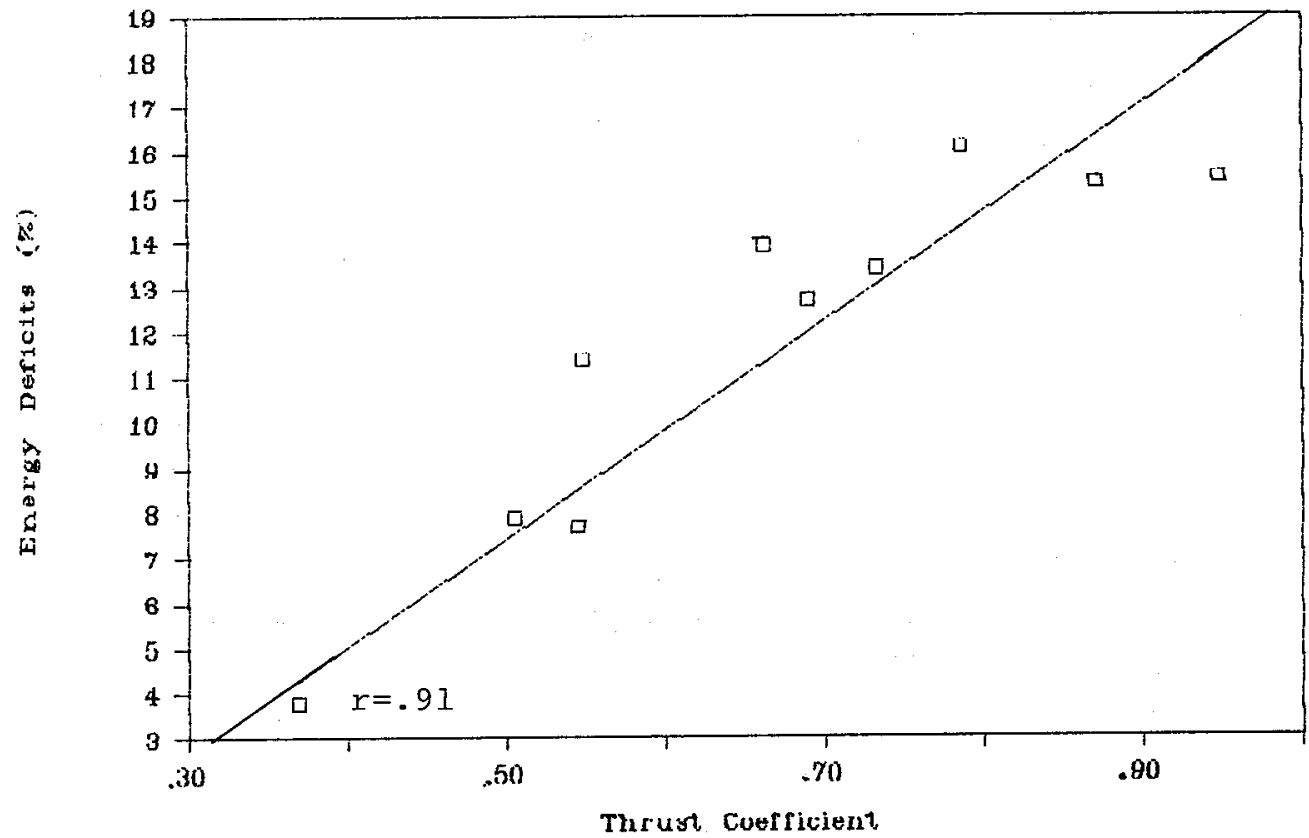

Figure 3-1.f. Wake Deficits (\%) vs. Thrust Coefficient 
Wind speed deficits were analyzed in these tests as well. The turbine anemometers were at $35-\mathrm{ft}$ agl, which is about half of hub-height. The speed deficits ranged from 0 to $7.3 \%$, which is considerably lower than the energy deficits. The speed deficits were relatively low because the sensors were probably below the wake centerline.

\subsection{Sixteen-Diameter Test}

The Sixteen-Diameter Test is a variation of the Direct Wake Effect Test. The only difference is the spacing between rows, which is roughly double in these tests. The purpose of this test was to see if wake effects were present at this distance. Many developers had assumed that wake deficits would be negligible at $10 \mathrm{D}$, which is the spacing of many commercial windfarm arrays. In this test, the middle row in the array was switched off for the duration of the test and the next row, which is $16 \mathrm{D}$ upwind of the test row, was switched on and off. The downwind row was the test row, and energy production data were analyzed in the same fashion as in the direct wake test. For additional discussion of test methodology, see Section 2.4. Two sixteen-diameter tests were conducted on the Jess-C array. Turbines L1 through L6 were turned on and off, and data from $M 1$ through $M 8$ were analyzed. The wind direction in the second test was about $10^{\circ}$ more westerly than normal, so the wake trajectory was a bit more westerly than the array axis. Therefore, energy data were analyzed from turbines $M 1$ and $M 2$, even though they were not part of the Jess $C$ array. Turbine M2 was operating, but the CTM was not communicating, so the data were not available. The tests were conducted on:

1) June 14, 1988, 17:40 - June 15, 1988 03:20 (10 h)

2) June $16,1988,12: 30-20: 20(8 \mathrm{~h})$

In addition to these two tests, there was one aborted test that lasted $2 \mathrm{~h}$. This test was aborted because of high winds. The data from this test are included in the analysis in Section 3.2.3.

\subsubsection{Test 1 Analysis, Jess-C, June 14-15, 1988}

Table 3-2.a is the data listing for the June $14-15$ test. See page 11 for a complete description of the data format. Wind speeds at the upwind reference, J08, averaged $22 \mathrm{mph}$ with a mean direction of $256^{\circ}$. Wind speeds at the test turbines were 1 to $2 \mathrm{mph}$ lower. Because wind speeds at j08 were a little lower in the first block of data, a "normalized" data set was used to reduce this possible bias between test periods.

The energy ratios between periods, at the bottom of the page, reveal the energy deficits. Using the normalized period, the table shows that the deficits decreased uniformly and ranged from almost $17 \%$ at turbine $M 3$ to zero at M8. With a mean wind direction of $256^{\circ}$, one would not expect the wake to impinge on M8. The mean energy deficit at turbines M1 through M6 was $12.9 \%$. This is quite remarkable, since this deficit at $16 \mathrm{D}$ is nearly identical to those measured in the direct wake tests, in which the distance between rows was only $8 \mathrm{D}$. One would not expect wakes to be this persistent at such great distances. There are two possible explanations for these results. First, the data were collected mostly at night, presumably under stable atmospheric conditions. Wakes are expected to be more persistent under stable conditions 
Table 3-2.a Sixteen Rotor Dianeter Hate Iest 1

POR HIUDRABU: JPSS BALCR NINDPABY

REPORT

Ten Vinute Data Report

Tine rons on Job J08

\begin{tabular}{|c|c|c|c|c|c|c|c|c|c|c|c|c|c|c|}
\hline ----- & $\cdots$ & & & & & & & & & & & - & & \\
\hline $17: 50$ & 0 & 17.4 & 252 & 2.1 & 2.9 & 3.5 & 4.2 & 4.7 & 5 & 5.1 & 17.4 & 15.8 & 17.4 & 18.5 \\
\hline $21: 50$ & 0 & 17.7 & 257 & 2.1 & 3 & 4.3 & 5.5 & 6 & 6.8 & 6.8 & 20.9 & 16.5 & 18.6 & 21.4 \\
\hline $18: 40$ & 0 & 18.7 & 257 & 1.5 & 3.3 & 4.3 & 5 & 5.4 & 5.7 & 5.8 & 19.5 & 16.8 & 18.4 & 19.6 \\
\hline $21: 10$ & 0 & 19.5 & 260 & 1.5 & 3.3 & 4.3 & 5.1 & 5.7 & 6.3 & 6.3 & 19.9 & 16.3 & 18 & 20.1 \\
\hline $18: 50$ & 0 & 19.6 & 255 & 1.6 & 3.7 & 4.4 & 5.1 & 5.6 & 5.6 & 5.8 & 20.4 & 16.9 & 18.5 & 19.6 \\
\hline $17: 10$ & 0 & 19.7 & 246 & 2.1 & 4.1 & 4.2 & 4.1 & 4.6 & 4.8 & 5.3 & 19.1 & 16.9 & 17.6 & 19 \\
\hline $22: 50$ & 0 & 21.4 & 255 & 3.9 & 5.1 & 5.8 & 6 & 6.5 & 6.8 & 6.9 & 27.6 & 18.9 & 20.5 & 22.3 \\
\hline $00: 50$ & 0 & 21.6 & 257 & 4.8 & 6 & 6.5 & 7 & 7.1 & 7.1 & 7.3 & 31.4 & 20.6 & 21.9 & 23.8 \\
\hline $00: 10$ & 0 & 21.8 & 259 & 4.9 & 6.1 & 6.6 & 7.1 & 7.2 & 7.6 & 7.5 & 31.9 & 20.6 & 22.5 & 24.2 \\
\hline $01: 50$ & 0 & 21.9 & 252 & 4.7 & 5.7 & 6.2 & 6.7 & 7.2 & 7.8 & 8 & 30.5 & 19.3 & 21.4 & 23.8 \\
\hline $01: 10$ & 0 & 22 & 259 & 4.2 & 6 & 6.6 & 7 & 7.1 & 7.6 & 7.7 & 30.9 & 20.1 & 21.4 & 23.6 \\
\hline $19: 10$ & 0 & 22.1 & 249 & 1.3 & 4.2 & 5 & 5.1 & 5.8 & 5.4 & 5 & 21.7 & 17.7 & 18.6 & 17.8 \\
\hline $20: 40$ & 0 & 22.3 & 252 & 2.9 & 4.8 & 4.9 & 5.5 & 6.4 & 7.1 & 7.2 & 24.5 & 17.6 & 19.9 & 21.7 \\
\hline $19: 50$ & 0 & 22.3 & 249 & 1. 1 & 4 & 5.2 & 5.7 & 6 & 5.8 & 4.9 & 22 & 18.4 & 19.2 & 17.4 \\
\hline $22: 10$ & 0 & 22.1 & 260 & 4 & 6 & 6.2 & 6.7 & 7 & 7.1 & 7.2 & 29.9 & 19.1 & 20.7 & 22.3 \\
\hline $23: 10$ & 0 & 23.3 & 260 & 5.6 & 6.1 & 6.9 & 7.1 & 7.3 & 7.7 & 7.6 & 33.6 & 20.2 & 21.6 & 23.2 \\
\hline $02: 50$ & 0 & 23.5 & 260 & 4.8 & 6.5 & 7.1 & 8.1 & 8.1 & 8.3 & 8.2 & 34.9 & 21.1 & 22.7 & 24.4 \\
\hline $20: 50$ & 0 & 23.5 & 255 & 3.2 & 5.6 & 6.1 & 6.9 & 6.8 & 6.8 & 6.1 & 28.9 & 19.5 & 19.9 & 20.1 \\
\hline $02: 40$ & 0 & 24.2 & 262 & 5.1 & 7 & 7.5 & 8.1 & 8.3 & 8.6 & 8.4 & 36 & 21.9 & 24.1 & 25.1 \\
\hline $23: 50$ & 0 & 24.9 & 257 & 5.8 & 7.1 & 7.5 & 8 & 7.9 & 8.2 & 8 & 36.3 & 21.6 & 22.9 & 24.2 \\
\hline Yean: & & 21.5 & 256 & 3.4 & 5.1 & 5.7 & 6.2 & 6.5 & 6.8 & 6.8 & 26.9 & 18.8 & 20.3 & 21.6 \\
\hline Horn: & & 22.3 & 255 & 3.8 & 5.5 & 6.1 & 6.6 & 6.8 & 7.0 & 7.0 & 28.7 & 19.4 & 20.8 & 22.0 \\
\hline $18: 10$ & 1 & 18.3 & 253 & 1.5 & 2.3 & 2.5 & 3.1 & 3.5 & 4.7 & 5 & 12.9 & 15.2 & 16.2 & 18.8 \\
\hline $21: 20$ & 1 & 18.9 & 259 & 2 & 2.2 & 3 & 4 & 5 & 6.1 & 6.3 & 16.2 & 14.9 & 17.5 & 19.7 \\
\hline $18: 20$ & 1 & 19.1 & 256 & 1.6 & 2.5 & 3.2 & 3.9 & 4.4 & 4.9 & 5.2 & 15.6 & 17 & 17.9 & 19.2 \\
\hline $01: 20$ & 1 & 20.1 & 256 & 2.9 & 3.8 & 4.2 & 4.1 & 5 & 5.5 & 6.2 & 20.3 & 17.2 & 18.3 & 21.4 \\
\hline $23: 10$ & 1 & 20.7 & 259 & 2.9 & 3.9 & 4.5 & 4.9 & 5.2 & 6.3 & 6.4 & 21.4 & 18.1 & 18.9 & 21.1 \\
\hline $21: 10$ & 1 & 20.8 & 253 & 1.8 & 3.1 & 4.8 & 5.1 & 5.7 & 6.7 & 6.6 & 21.1 & 18.2 & 18.8 & 20.9 \\
\hline $01: 10$ & 1 & 21.3 & 257 & 3.7 & 4.9 & 5.2 & 5.6 & 6.2 & 6.2 & 6.6 & 25.6 & 19 & 20.2 & 22.1 \\
\hline $22: 10$ & 1 & 21.4 & 262 & 3 & 4.5 & 5 & 5.3 & 5.6 & 6.5 & 6.5 & 23.1 & 18.3 & 19.1 & 20.7 \\
\hline $00: 20$ & 1. & 21.6 & 256 & 3.9 & 5 & 5.7 & 6.1 & 6.6 & 7.2 & 7.1 & 27.3 & 20 & 21.1 & 24.1 \\
\hline $02: 20$ & 1 & 22.1 & 256 & 3.6 & 5.2 & 5.9 & 6.6 & 7.3 & 8.2 & 8.1 & 28.6 & 19.5 & 21.7 & 24.3 \\
\hline $20: 10$ & 1 & 22.4 & 253 & 1.9 & 3.9 & 4 & 1.1 & 4.6 & 5.4 & 5.8 & 18.8 & 17.1 & 17.6 & 18.9 \\
\hline $00: 10$ & 1 & 22.1 & 257 & 3.9 & 5.4 & 6.3 & 6.7 & 7 & 7.8 & 7.8 & 29.3 & 20.8 & 22 & 24.8 \\
\hline $23: 20$ & 1 & 22.7 & 259 & 4 & 5.1 & 5.7 & 6 & 6.3 & 7.3 & 7.3 & 27.1 & 19.3 & 20.5 & 23.1 \\
\hline $22: 20$ & 1 & 22.7 & 262 & 3.6 & 5.2 & 5.4 & 5.6 & 6 & 6.9 & 7 & 25.8 & 18.9 & 19.8 & 21.9 \\
\hline $02: 10$ & 1 & 23.1 & 260 & 4.8 & 6 & 6.9 & 7.8 & 8.2 & 9.2 & 9.1 & 33.7 & 21.3 & 23.5 & 25.9 \\
\hline $20: 20$ & 1 & 23.4 & 253 & 3.4 & 4.7 & 5.4 & 6.1 & 6.8 & 6.9 & 6.9 & 26.1 & 18.8 & 20.7 & 21.6 \\
\hline $19: 10$ & 1 & 23.4 & 245 & 1.8 & 4.2 & 4.8 & 5 & 5.2 & 5.2 & 5.6 & 21 & 18.2 & 18.5 & 19.2 \\
\hline $19: 20$ & 1 & 24.7 & 245 & 1.8 & 4.3 & 5.1 & 5.4 & 5.6 & 5.7 & 6.2 & 22.2 & 18.7 & 18.9 & 20.4 \\
\hline $03: 10$ & 1 & 27.3 & 260 & 6.4 & 7.6 & 8.1 & 9.1 & 9.1 & 9.9 & 9.9 & 40.3 & 23.4 & 25.1 & 27.5 \\
\hline $03: 20$ & 1 & 28.8 & 262 & 6.9 & 8.3 & 8.7 & 9.7 & 9.7 & 10.5 & 10.5 & 43.3 & 24.9 & 27.1 & 29.6 \\
\hline Uean: & & 22.3 & 256 & 3.3 & 4.6 & 5.2 & 5.8 & 6.2 & 6.9 & 7.0 & 25.0 & 18.9 & 20.2 & 22.3 \\
\hline Ratios 1 & & & & & & & & & & & & & & \\
\hline Lll data & & 103.7 & & 97.3 & 91.4 & 91.8 & 92.4 & 94.1 . & 100.5 & 103.9 & 93.1 & 100.7 & 99.4 & 103.1 \\
\hline Hornalis & & 100.0 & & 87.2 & 83.4 & 85.8 & 87.9 & 90.4 & 97.1 & 101.0 & 87.1 & 97.5 & 96.8 & 101.1 \\
\hline
\end{tabular}

$06 / 14 / 88$

$06 / 15 / 88$

$403 \quad 304 \quad 405 \quad 406 \quad 607 \quad 608$ sun of energy $\mathrm{v} 01-\mathrm{y} 06$ 
because there is less mixing. A second reason could be the low subsidence inversion. The depth of the marine layer or flux layer in this part of the Altamont is estimated to have been very shallow on this date, on the order of $200 \mathrm{ft}$ thick. This is not an unusual event in the Altamont Pass, although this layer is normally several hundred feet thicker. Typically there is very little wind energy above the top of the inversion in the Altamont. If the flux layer were this shallow, one would expect wake deficits to be very persistent because there is only a small reservoir of momentum aloft to restore the lost energy. If the persistence of these deficits is a function of the shallow inversion peculiar to the Altamont Pass, these results may have 1imited application outside this area.

Wind speed data from the 35-ft anemometers at M4, M6, and M8 were analyzed. Turbine M8 had no deficit (actually a $1 \%$ increase in speed), and M4 and M6 had speed deficits of $2.5 \%$ and $3.2 \%$, respectively. Power density deficits (W/m $/ \mathrm{m}^{2}$ ) were also calculated from the anemometer data. The deficits were $4.7 \%$ and $6.5 \%$ at $M 4$ and $M 6$. These speed and power density deficits are quite small compared to the energy deficits, and this may be due to the fact that the anemometers are not at hub-height and could be well below the wake centerline.

Although the middle ( 8 D) row turbines were shut off during this test, wind speed data were available and analyzed at turbines L8, L10, and L12. This permits a comparison of speed and power density deficits at 8 D versus 16 D. The speed deficits at $L 8$ and $L 10$ were $3.0 \%$ and $2.9 \%$, respectively, and $L 12$ had no deficit. These speed deficits are very similar to those at $M 4, M 6$, and M8. The power density deficits at $L 8$ and $L 10$ were $5.2 \%$ and $6.0 \%$, respectively. These are within $0.5 \%$ of the deficits at turbines M4 and M6. Thus we see that there were practically no differences in the speed and power density deficits between $8 \mathrm{D}$ and $16 \mathrm{D}$ (at $35 \mathrm{ft}$ agl).

The statistical significance of the row energy deficit of $12.9 \%$ was 0.95 . The energy deficit of $16.6 \%$ at turbine M3 was significant at the 0.975 level.

\subsubsection{Test 2 Analysis, Jess-C, June 16, 1988}

Table 3-2.b is the data listing for the June 16 test. Wind speeds were nearly identical to the first test; however, the mean wind direction was about $5^{\circ}$ more westerly. Data in the second block (upwind turbines on line) were sorted by J08 wind direction. A second set of means that excluded the westerly (last 2) records was calculated. In winds with a direction of $270^{\circ}$, the expected wake trajectory would miss all turbines except M1 through M3.

There are two sets of energy ratios at the bottom of the page: one for all data and one with the directional screening. The analysis will focus on the latter. The energy ratios ranged from $83.9 \%$ at $M 1$ to $103.1 \%$ at M8. Turbines M6 through M8 had no deficits at all, which is not surprising based on the wind direction. Turbine $M I$ had the largest deficit, $16.1 \%$, and deficits decreased steadily down the row to $M 6$. The mean deficit at turbines $M 1$ through M4 was $10.6 \%$, which is lower than in the first test. Much of this difference is attributable to the wind direction, as the maximum individual turbine deficit was about the same in both tests: $16.1 \%$ versus $16.6 \%$.

The wind speed deficit was $3 \%$ at turbine $M 4$ and there was no speed deficit at M6 and M8. This is quite similar to the first test. 
Fable 3-2.b Sixteen lotor Dianeter llake Test 2

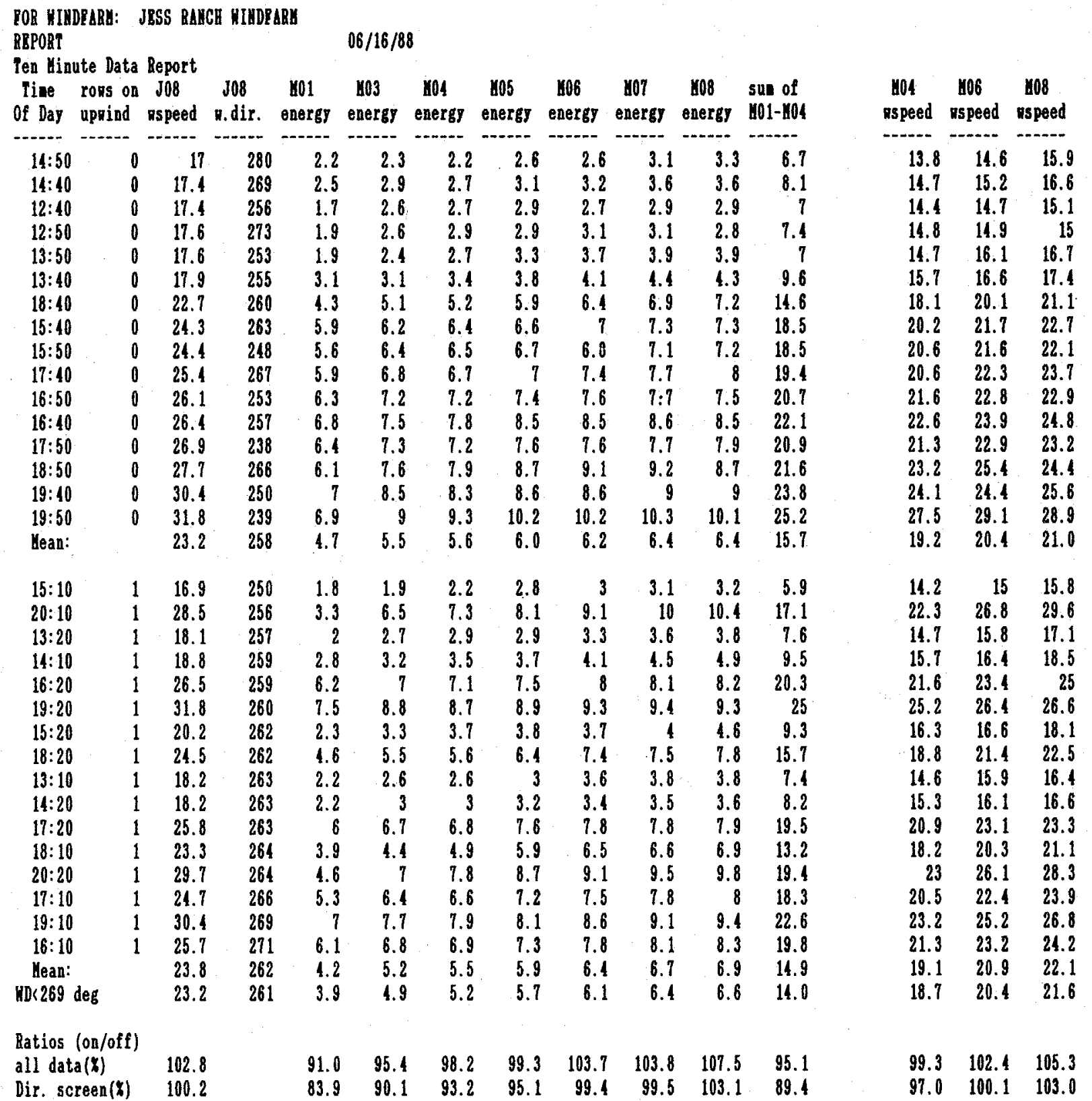


The results of this test confirm that the wake energy deficits do persist well beyond $10 \mathrm{D}$. The second test took place in afternoon and early evening hours. Therefore, the subsidence inversion was probably weakened and considerably higher for part of this test because of daytime surface heating. Thus, the deficits measured in the first test were not an anomaly merely associated with stable nighttime conditions and an extremely shallow subsidence inversion.

The statistical significance of the mean deficit of $10.6 \%$ was 0.75 . This indicates that there is a $25 \%$ possibility that these results could have occurred by chance. The $16.1 \%$ deficit at turbine $M 1$ had a significance level of 0.80 , which is slightly better.

\subsubsection{Combined File Analysis}

Data from the two tests discussed above and the aborted test were combined into a single file for further analysis. Table 3-2.c contains these data. The data were screened by J08 wind direction and speed. There are four sets of means and ratios. The first set analyzes all available data, while the second through fourth sets analyze records with wind directions less than $260^{\circ}$. The second set is all records with wind directions below $260^{\circ}$, and the third and fourth sets are low and high wind-speed subsets. Turbine M8 was not analyzed, as it was shown in the previous discussions to be out of the expected wake trajectory.

The ratios show that the mean deficit for turbines M1 through M5 was $11.1 \%$ using all data (first set of ratios) and $12.1 \%$ using only the records screened by wind direction (second set). These deficits are plotted on Figure 3-2.a. The deficits decrease uniformly across the row from M1 to M7. Using the second set of ratios, $M I$ had a deficit of $14.2 \%$ and $M 7$ had a deficit of about $3.5 \%$. The speed deficits at $35 \mathrm{ft}$ agl at $\mathrm{M} 4$ and $M 6$ were about $2 \%$.

The third and fourth sets of ratios show the inverse relationship between wind speed and energy deficits. The low speed data set (third) had mean speeds at J08 of $19.5 \mathrm{mph}$ and about $16 \mathrm{mph}$ to $18 \mathrm{mph}$ at $\mathrm{M} 4$ and $\mathrm{M} 6$. The mean energy deficit at $M 1$ through $M 5$ was $18.5 \%$, and $M 3$ had the highest deficit, about $21 \%$. The speed deficits were about $4 \%$ and $5 \%$ at $M 4$ and $\mathrm{M} 6$. The high speed data set (fourth) had mean speeds at J08 of $26.4 \mathrm{mph}$ and $22 \mathrm{mph}$ to $23 \mathrm{mph}$ at M4 and M6. The mean energy deficit dropped dramatically to $10.1 \%$ (versus $18.5 \%$ ). Turbine $M 1$ had the worst deficit, about $16 \%$. There were practically no speed deficits at M4 and M6. Thus we see that with a 7-mph increase in speed at J08, the mean energy deficit dropped by $8.4 \%$. This is a larger drop in energy for a given change in wind speed than in the direct wake tests. Recall that the slope of the best fit line for those tests was about -0.8 . This implies that a 7 -mph change in wind speed would yield about a $5 \%$ change in the deficits. Thus, it appears that the $16 \mathrm{D}$ energy deficits are even more sensitive to changes in speed than the $8 \mathrm{D}$ deficits. Regression analysis (not plotted) of these two variables from this limited data set shows that the slope of the best fit line is about -1.5 , much steeper than the direct wake tests. The zero intercept is much lower than the direct wake test: 31 mph versus $35 \mathrm{mph}$. This suggests that negligible deficits would be expected at $16 \mathrm{D}$ above $31 \mathrm{mph}$. 
Table 3-2.c Sixteen Rotor Dianeter hake Test, Conbined Pile

Ten Hinute Data Report

POR HIYDPARY: JRSS BAYCE NINDPABY

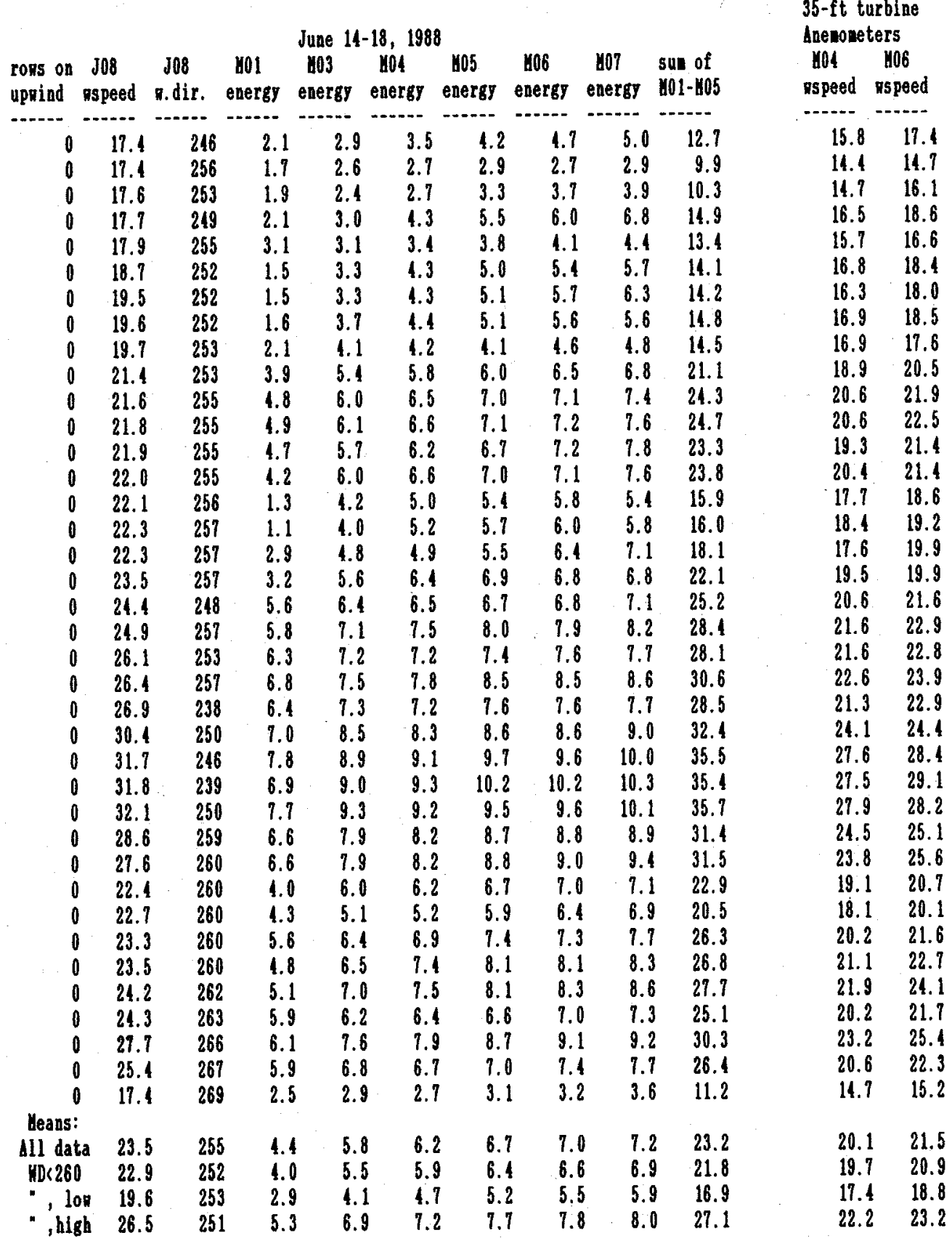

Page 1 of 2 
Table 3-2.c Sirteen Rotor Dianeter lake Test, Conbined Pile

\begin{tabular}{|c|c|c|c|c|c|c|c|c|c|c|c|}
\hline $\begin{array}{l}\text { ross on } \\
\text { uppind }\end{array}$ & $\begin{array}{c}\text { J08 } \\
\text { sspeed }\end{array}$ & $\begin{array}{c}\text { Jo8 } \\
\text { R.dir. }\end{array}$ & $\begin{array}{c}\text { yo1 } \\
\text { energy }\end{array}$ & $\begin{array}{l}103 \\
\text { energy }\end{array}$ & $\begin{array}{c}104 \\
\text { energy }\end{array}$ & $\begin{array}{c}\text { y05 } \\
\text { energy }\end{array}$ & $\begin{array}{c}\text { uo6 } \\
\text { energy }\end{array}$ & $\begin{array}{c}\text { rol } \\
\text { energy }\end{array}$ & $\begin{array}{l}\text { sun of } \\
\text { up1- } 1005\end{array}$ & $\begin{array}{c}\text { Y04 } \\
\text { aspeed }\end{array}$ & $\begin{array}{c}1406 \\
\text { Rspeed }\end{array}$ \\
\hline 1 & 30.6 & 243 & 7.7 & 8.8 & 8.5 & 9.0 & 9.0 & 9.3 & 34.0 & 26.3 & 27.0 \\
\hline 1 & 16.9 & 250 & 1.8 & 1.9 & 2.2 & 2.8 & 3.0 & 3.1 & 8.7 & 14.2 & 15.0 \\
\hline 1 & 18.1 & 257 & 2.0 & 2.7 & 2.9 & 2.9 & 3.3 & 3.6 & 10.5 & 14.7 & 15.8 \\
\hline 1 & 18.3 & 250 & 1.5 & 2.3 & 2.5 & 3.1 & 3.5 & 4.7 & 9.1 & 15.2 & 16.2 \\
\hline 1 & 18.8 & 259 & 2.8 & 3.2 & 3.5 & 3.7 & 4.1 & 4.5 & 13.2 & 15.7 & 16.4 \\
\hline 1 & 18.9 & 253 & 2.0 & 2.2 & 3.0 & 1.0 & 5.0 & 6.1 & 11.2 & 14.9 & 17.5 \\
\hline 1 & 19.1 & 253 & 1.6 & 2.5 & 3.2 & 3.9 & 4.4 & 4.9 & 11.2 & 17.0 & 17.9 \\
\hline 1 & 20.4 & 253 & 2.9 & 3.8 & 4.2 & 1.4 & 5.0 & 5.5 & 15.3 & 17.2 & 18.3 \\
\hline 1 & 20.7 & 256 & 2.9 & 3.9 & 4.5 & 4.9 & 5.2 & 6.3 & 16.2 & 18.1 & 18.9 \\
\hline 1 & 20.8 & 256 & 1.8 & 3.4 & 1.8 & 5.4 & 5.7 & 6.7 & 15.1 & 18.2 & 18.8 \\
\hline 1 & 21.3 & 256 & 3.7 & 1.9 & 5.2 & 5.6 & 6.2 & 6.2 & 19.4 & 19.0 & 20.2 \\
\hline 1 & 21.6 & 256 & 3.9 & 5.0 & 5.7 & 6.1 & 6.6 & 7.2 & 20.7 & 20.0 & 21.1 \\
\hline 1 & 22.1 & 256 & 3.6 & 5.2 & 5.9 & 6.6 & 7.3 & 8.2 & 21.3 & 19.5 & 21.7 \\
\hline 1 & 22.4 & 257 & 1.9 & 3.9 & 1.0 & 4.4 & 4.6 & 5.1 & 14.2 & 17.1 & 17.6 \\
\hline 1 & 22.4 & 257 & 3.9 & 5.1 & 6.3 & 6.7 & 7.0 & 7.8 & 22.3 & 20.8 & 22.0 \\
\hline 1 & 22.7 & 257 & 4.0 & 5.1 & 5.7 & 6.0 & 6.3 & 7.3 & 20.8 & 19.3 & 20.5 \\
\hline 1 & 23.4 & 259 & 3.4 & 4.7 & 5.4 & 6.1 & 6.8 & 6.9 & 19.6 & 18.8 & 20.7 \\
\hline 1 & 23.4 & 259 & 1.8 & 1.2 & 1.8 & 5.0 & 5.2 & 5.2 & 15.8 & 18.2 & 18.5 \\
\hline 1 & 24.7 & 259 & 1.8 & 4.3 & 5.1 & 5.4 & 5.6 & 5.7 & 16.6 & 18.7 & 18.9 \\
\hline$i$ & 26.5 & 259 & 6.2 & 7.0 & 7.1 & 7.5 & 8.0 & 8.1 & 27.8 & 21.6 & 23.4 \\
\hline 1 & 28.5 & 256 & 3.3 & 6.5 & 7.3 & 8.1 & 9.1 & 10.0 & 25.2 & 22.3 & 26.8 \\
\hline 1 & 32.7 & 253 & 7.4 & 8.8 & 8.9 & 9.6 & 9.5 & 9.7 & 34.7 & 27.7 & 28.1 \\
\hline 1 & 33.2 & 253 & 7.7 & 9.3 & 9.5 & 10.2 & 10.5 & 10.8 & 36.7 & 29.4 & 32.1 \\
\hline 1 & 23.1 & 260 & 1.8 & 6.0 & 6.9 & 7.8 & 8.2 & 9.2 & 25.5 & 21.3 & 23.5 \\
\hline 1 & 27.3 & 260 & 6.4 & 7.6 & 8.1 & 9.1 & 9.1 & 9.9 & 31.2 & 23.1 & 25.1 \\
\hline 1 & 31.8 & 260 & 7.5 & 8.8 & 8.7 & 8.9 & 9.3 & 9.1 & 33.9 & 25.2 & 26.4 \\
\hline 1 & 20.2 & 262 & 2.3 & 3.3 & 3.7 & 3.8 & 3.7 & 4.0 & 13.1 & 16.3 & 16.6 \\
\hline 1 & 21.4 & 262 & 3.0 & 1.5 & 5.0 & 5.3 & 5.6 & 6.5 & 17.8 & 18.3 & 19.1 \\
\hline 1 & 22.7 & 262 & 3.6 & 5.2 & 5.4 & 5.6 & 6.0 & 6.9 & 19.8 & 18.9 & 19.8 \\
\hline 1 & 24.5 & 262 & 4.6 & 5.5 & 5.6 & 6.4 & 7.1 & 7.5 & 22.1 & 18.8 & 21.4 \\
\hline 1 & 28.8 & 262 & 6.9 & 8.3 & 8.7 & 9.7 & 9.7 & 10.5 & 33.6 & 24.9 & 27.1 \\
\hline 1 & 32.7 & 262 & 8.1 & 9.1 & 9.3 & 9.9 & 10.0 & 10.2 & 36.7 & 27.7 & 29.7 \\
\hline 1 & 18.2 & 263 & 2.2 & 2.6 & 2.6 & 3.0 & 3.6 & 3.8 & 10.1 & 14.6 & 15.9 \\
\hline 1 & 18.2 & 263 & 2.2 & 3.0 & 3.0 & 3.2 & 3.1 & 3.5 & 11.4 & 15.3 & 16.1 \\
\hline 1 & 25.8 & 263 & 6.0 & 6.7 & 6.8 & 7.6 & 7.8 & 7.8 & 27.1 & 20.9 & 23.1 \\
\hline 1 & 23.3 & 261 & 3.9 & 1.4 & 4.9 & 5.9 & 6.5 & 6.6 & 19.1 & 18.2 & 20.3 \\
\hline 1 & 29.7 & 264 & 1.6 & 7.0 & 7.8 & 8.7 & 9.1 & 9.5 & 28.1 & 23.0 & 26.1 \\
\hline \multirow{2}{*}{\multicolumn{12}{|c|}{ Heans: }} \\
\hline & & & & & & & & & & & \\
\hline All data & 23.5 & 258 & 3.9 & 5.1 & 5.5 & 6.1 & 6.5 & 6.9 & 20.6 & 19.6 & 21.1 \\
\hline $\mathrm{KD}<260$ & 22.9 & 255 & 3.5 & 4.7 & 5.2 & 5.7 & 6.1 & 6.7 & 19 & 19.3 & 20.6 \\
\hline - , lor & 19.5 & 255 & 2.4 & 3.3 & 3.8 & 4.3 & 4.7 & 5.3 & 13.7 & 16.7 & 17.8 \\
\hline \multirow{2}{*}{\multicolumn{12}{|c|}{ Ratios (on/off $x$ ) }} \\
\hline & & & & & & & & & & & \\
\hline all data & 100.1 & & 87.5 & 87.9 & 89.2 & 90.3 & 92.8 & 96.1 & 88.9 & 97.4 & 98.0 \\
\hline$N D<260$ & 100.0 & & 85.8 & 86.8 & 88.7 & 89.4 & 92.4 & 96.5 & 87.9 & 98.0 & 98.3 \\
\hline " , lor & 99.7 & & 85.4 & 79.1 & 81.0 & 81.8 & 85.3 & 90.6 & 81.5 & 96.2 & 94.7 \\
\hline • , high & 99.5 & & 84.3 & 89.5 & 91.7 & 92.5 & 95.1 & 98.1 & 89.9 & 98.6 & 100.1 \\
\hline
\end{tabular}

Page 2 of 2 


\section{2 .4 Summary}

Two sixteen-diameter tests were conducted at the Jess-C array. A third test was aborted after $2 \mathrm{~h}$, but the data were included in the analysis. The results of the two tests were quite similar. In the first test, the mean energy deficit was $12.9 \%$ and the maximum individual turbine deficit was $16.6 \%$. In the second test, with slightly higher wind speeds, the mean energy deficit was $10.6 \%$, and the maximum individual deficit was $16.1 \%$. Speed deficit data were available from the $35-f t$ anemometers on turbines at $8 \mathrm{D}$ and $16 \mathrm{D}$. There were practically no differences between the $8 \mathrm{D}$ and $16 \mathrm{D}$ speed deficits. The speed deficits at $16 \mathrm{D}$ ranged from $2.5 \%$ to $3.2 \%$. At $8 \mathrm{D}$, the deficits were $2.9 \%$ to $3.0 \%$. Power density deficits were calculated from the $35-\mathrm{ft}$ wind speed data and these also showed the similarity between the $8 \mathrm{D}$ and $16 \mathrm{D}$ sites. At $16 \mathrm{D}$, the power density deficits were $4.7 \%$ to $6.5 \%$, and at $8 \mathrm{D}$ they were $5.2 \%$ to $6.0 \%$.

The sixteen-diameter tests resulted in an average energy deficit, when screened by direction, of $12.1 \%$ at the affected turbines. This is quite remarkable, considering the distance between rows, and that these deficits are just as high as those measured in rows separated by only $8 \mathrm{D}$. In fact they are almost identical to the deficits measured in the $8 \mathrm{D}$ tests that took place in this same array. Recall that in the combined file in Section 3.1 .7 , in the subset with the mean speed of $22.7 \mathrm{mph}$, the energy deficit was $12.7 \%$.

Regression analysis of wind speed versus energy deficit data showed an inverse relationship. The slope of the best-fit line was much steeper in the $16 \mathrm{D}$ tests than in the 8 D tests. This implies that a given increase in wind speed produced a larger decrease in the deficit. The zero intercept was about 31 mph, i.e., negligible deficits are expected above this speed at $16 \mathrm{D}$.

Figure 3-2.a is a topographic map of the Jess-C turbines with the individual turbine deficits plotted on it. The length of the bars is proportional to the deficit and the bars are plotted parallel to the mean wind direction. The figure uses only the data records with wind direction less than $260^{\circ}$. It is interesting to compare it to Figure 3-1.c in Section 3.1.7. Figure 3-2.a shows the results of the 16 D tests. Figure $3-1 . c$ shows the results of the 8 D tests conducted on the same turbines. The two figures illustrate the remarkable similarity of the test results, in spite of the different test conditions (upwind spacing).

Figure 3-2.a helps to illustrate how terrain effects can enhance wake deficits. The turbines at the southern end of the row, $M 1$ and $M 3$, are at lower elevations than the northern end. These turbines had lower energy output (lower winds) during the test and during the free-flow study as well. Because of the inverse relationship between wind speed and wake deficits, these lower energy (and elevation) sites experienced higher deficits.

\subsection{Blockbuster Test}

The Blockbuster Test is similar to the Direct Wake Effect Test with one change. Instead of switching a single row of upwind turbines on and off, two rows of upwind turbines are switched on and off simultaneously. The downind (third) row is the test row where all analysis is performed. Additional discussion on the test methodology can be found in section 2.4 . 


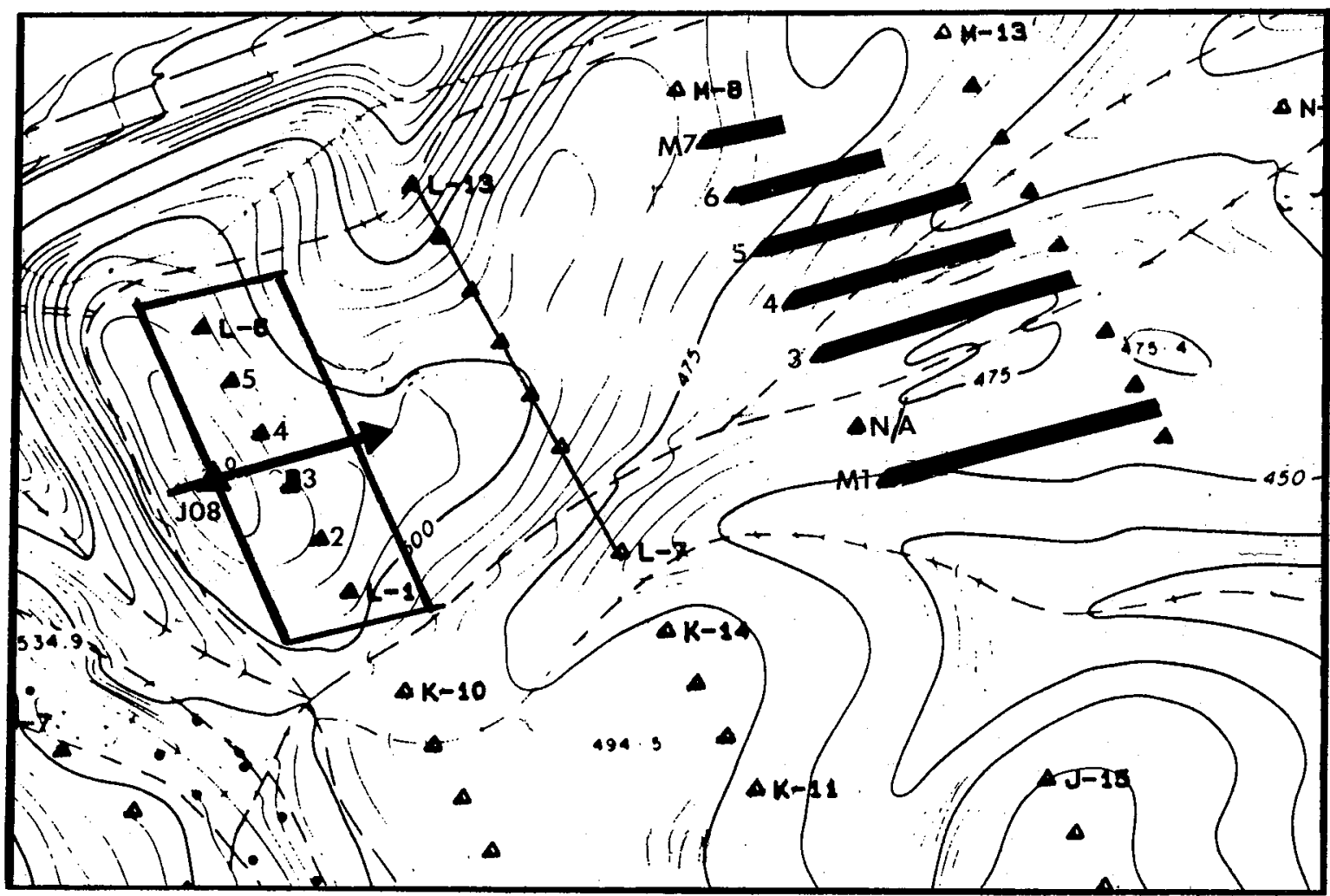

\section{Figure 3-2.a. Jess-C 16 RD Wake Tests \\ Individual Turbine Deficits}

June 14-16, 1988 test conditions at reference anemometer, J-08:

mean speed $=22.9 \mathrm{mph}$, mean direction $=255$ degrees.

\section{KEY}

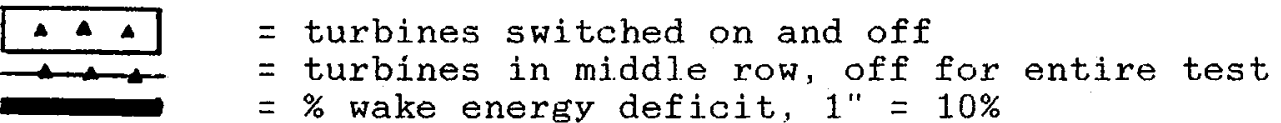

Deficits (samples with wind direction $<260$ degrees)

$\begin{array}{rr}\text { M1 } & 14.2 \% \\ \text { M2 } & \text { N } / A=\text { not available } \\ \text { M3 } & 13.2 \% \\ \text { M4 } & 11.3 \% \\ \text { M5 } & 10.6 \% \\ \text { M6 } & 7.6 \% \\ \text { M7 } & 3.5 \% \\ \text { M1-M5 } & 12.1 \%\end{array}$


Two blockbuster tests were conducted and neither used buffer turbines.

1. Jess-C group, September 25, 1987, 09:00-19:00 PDT (10 hours).

2. Souza-C group, October $7,1987,13: 30-24: 00$ PDT (10-1/2 hours).

\subsubsection{Test 1 Analysis, Jess-C, September 25, 1987}

Table 3-3.a is the data listing for the Blockbuster Test that took place on Jess-C on September 25, 1987. A complete description of the data format can be found on page 11. The spacing between all three test rows is about $8 \mathrm{D}$. The table shows that the mean speed at J08 was about $20 \mathrm{mph}$ from the west-southwesterly. Mean speeds at the turbine anemometers were quite low, ranging from $15 \mathrm{mph}$ to $18 \mathrm{mph}$. The mean speeds at the j08 anemometer for the two test periods were almost identical, indicating little possible bias.

The energy ratios between the two test periods reveal the magnitude of the energy deficits. The mean ratio of the six test turbines was $75.4 \%$, which is equivalent to an energy deficit of $24.6 \%$. The pattern within the row was quite clear; energy ratios were lowest at $M 3,66.0 \%$; and highest at M8, $90.3 \%$. The terrain, which slopes gently down from the higher ground at M8 to $\mathrm{M} 2$, was probably a factor in this pattern. The free-flow study results showed a steady decrease in wind speeds from M8 to M2. This pattern was also seen in this test. Because of the inverse relationship between wind speed and deficits discussed in the previous sections, the lower energy sites (lower winds) experienced higher deficits. A second factor probably contributing to the loss pattern is the good exposure of M8 to the free-stream flow. Turbine M8 is on the edge of the array and has good exposure to the large channel that Interstate 580 passes through. On the other hand, turbine M3 is embedded in the array and is not exposed to this channel.

The statistical significance of the row deficit was 0.99 . For turbine M3, which had the largest deficit, the significance was 0.995 .

Although not shown on the table, the data were stratified by wind speed. A second set of means and ratios was calculated for the windier half of the observations. This stratified data set had a mean wind speed at J08 of $21.7 \mathrm{mph}$, about $2 \mathrm{mph}$ higher than the overall mean. Deficits at all turbines decreased by about $3 \%$ and the row deficit was $22.0 \%$, versus $24.6 \%$ for the overall data set.

Some additional analyses were performed on this test data set because the deficits were so large. Figure $3-3 . a$ is a plot of J08 wind speed versus turbine energy. The data is from Table 3-3.a. There are two plots. The upper plot is J08 wind versus turbine M03 energy. Turbine M03 had the largest deficits. The plot shows two symbols, one for non-wake data and one for the periods in which the two upwind rows were on. The figure shows that for a given wind speed, there is a one to two $\mathrm{kWh}$ difference in 10-min energy production between wake and nonwake situations. The 1 ines connecting the symbols are roughly parallel, indicating fairly uniform absolute deficits over the range of wind speeds. However, because the absolute deficit remains fairly constant in winds above $21 \mathrm{mph}$, at about $1.75 \mathrm{kWh}$, it decreases on a percentage basis. 
Table 3-3. a Jess-C Blockbuster Test Analysis

Ten Minute Data Report

FOR WINDEARM: JESS RANCH WINDEARM

Ten Minute Data Report

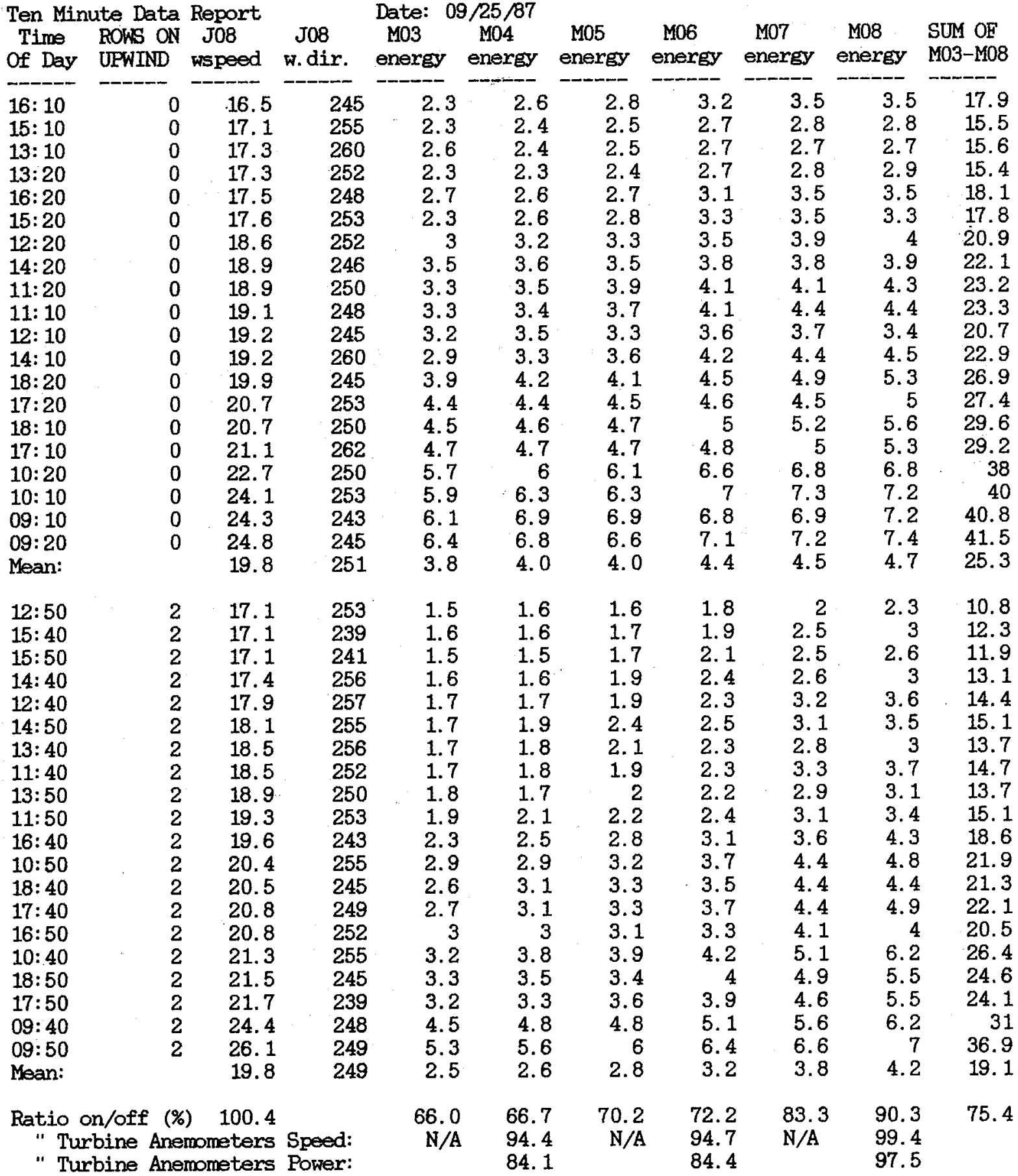


Table 3-3. a Jess-C Blockbuster Test Analysis

\begin{tabular}{|c|c|c|c|c|c|c|c|c|c|c|}
\hline $\begin{array}{l}\text { Time } \\
\text { Of Day }\end{array}$ & $\begin{array}{l}\text { ROWS ON } \\
\text { UPWIND }\end{array}$ & $\begin{array}{l}\text { Turbine } \\
\text { M04 } \\
\text { wspeed }\end{array}$ & $\begin{array}{l}\text { Anemomet } \\
\text { M04 } \\
\text { W/sq. } m\end{array}$ & $\begin{array}{l}\text { ter Wind } \\
\text { M06 } \\
\text { wspeed }\end{array}$ & $\begin{array}{l}\text { Speed An } \\
\text { M06 } \\
\text { W/sq. m }\end{array}$ & $\begin{array}{l}\text { nalysis } \\
\text { M08 } \\
\text { wspeed }\end{array}$ & $\begin{array}{r}\text { M08 } \\
\text { W/sq. m }\end{array}$ & $\begin{array}{c}\text { Ratios } \\
\text { M04 } \\
\text { (\%) }\end{array}$ & to $\begin{array}{c}\mathrm{J}-08 \\
\mathrm{M} 06 \\
(\%)\end{array}$ & $\begin{array}{r}50-f t \\
\text { Mo8 } \\
(\%)\end{array}$ \\
\hline $16: 10$ & 0 & 14.5 & 166.8 & 15.8 & 215.8 & 16.6 & 250.2 & 87.8 & 95.6 & 100.5 \\
\hline $15: 10$ & 0 & 14.3 & 160.0 & 15 & 184.6 & 15.1 & 188.3 & 83.6 & 87.7 & 88.3 \\
\hline $13: 10$ & 0 & 14.2 & 156.6 & 14.7 & 173.8 & 15.3 & 195.9 & 82.1 & 85.0 & 88.4 \\
\hline $13: 20$ & 0 & 14.1 & 153.3 & 14.5 & 166.8 & 15.3 & 195.9 & 81.5 & 83.8 & 88.4 \\
\hline $16: 20$ & 0 & 14.6 & 170.2 & 15.4 & 199.8 & 16.1 & 228.3 & 83.4 & 88.0 & 92.0 \\
\hline $15: 20$ & 0 & 14.3 & 160.0 & 15.6 & 207.7 & 16.1 & 228.3 & 81.3 & 88.7 & 91.5 \\
\hline $12: 20$ & 0 & 15.2 & 192. 1 & 16.2 & 232.6 & 17 & 268.7 & 81.9 & 87.3 & 91.6 \\
\hline $14: 20$ & 0 & 15.9 & 219.9 & 16.5 & 245.7 & 17.1 & 273.5 & 84.3 & 87.5 & 90.7 \\
\hline $11: 20$ & 0 & 16.1 & 228.3 & 16.9 & 264.0 & 17.4 & 288.2 & 85.4 & 89.6 & 92.3 \\
\hline $11: 10$ & 0 & 16.1 & 228.3 & 17.1 & 273.5 & 17.5 & 293.2 & 84.5 & 89.8 & 91.9 \\
\hline $12: 10$ & 0 & 15.7 & 211.7 & 16.1 & 228.3 & 16 & 224.1 & 81.6 & 83.7 & 83.1 \\
\hline $14: 10$ & 0 & 15.4 & 199.8 & 16.8 & 259.4 & 17.6 & 298.2 & 80.0 & 87.3 & 91.4 \\
\hline $18: 20$ & 0 & 16.7 & 254.8 & 17.7 & 303. 3 & 19. 1 & 381.1 & 83.8 & 88.8 & 95.9 \\
\hline $17: 20$ & 0 & 16.9 & 264.0 & 17.4 & 288.2 & 18.5 & 346.3 & 81.6 & 84.0 & 89.4 \\
\hline 18: 10 & 0 & 17.6 & 298.2 & 18.6 & 352.0 & 19.9 & 431.1 & 85.0 & 89.8 & 96.1 \\
\hline $17: 10$ & 0 & 17.4 & 288.2 & 17.9 & 313.7 & 19.1 & 381.1 & 82.5 & 84.9 & 90.6 \\
\hline $10: 20$ & 0 & 19.2 & 387.2 & 20.8 & 492.2 & 21.7 & 558.9 & 84.4 & 91.4 & 95.4 \\
\hline $10: 10$ & 0 & 19.9 & 431.1 & 21.8 & 566.7 & 22.5 & 623.1 & 82.6 & 90.4 & 93.3 \\
\hline $09: 10$ & 0 & 21.6 & 551.2 & 21.5 & 543.6 & 23 & 665.5 & 88.9 & 88.5 & 94.7 \\
\hline $09: 20$ & 0 & 20.8 & 492.2 & 22.2 & 598.5 & 23. 1 & 674.3 & 83.9 & 89.6 & 93.2 \\
\hline Mean: & & 16.5 & 260.7 & 17.4 & 305.5 & 18.2 & 349.7 & 83.5 & 88.1 & 91.9 \\
\hline $12: 50$ & 2 & 13.2 & 125.8 & 13.8 & 143.8 & 14.6 & 170.2 & 77.2 & 80.7 & 85.3 \\
\hline $15: 40$ & 2 & 13.1 & 123.0 & 14.1 & 153. 3 & 16 & 224.1 & 76.6 & 82.4 & 93.5 \\
\hline $15: 50$ & 2 & 13.4 & 131.6 & 14.3 & 160.0 & 15.6 & 207.7 & 78.3 & 83.6 & 91.2 \\
\hline $14: 40$ & 2 & 13.8 & 143.8 & 15 & 184.6 & 16.1 & 228.3 & 79.3 & 86.2 & 92.5 \\
\hline $12: 40^{\circ}$ & 2 & 13.8 & 143.8 & 15 & 184.6 & 16.7 & 254.8 & 77.2 & 83.9 & 93.4 \\
\hline $14: 50$ & 2 & 14.5 & 166.8 & 15.2 & 192.1 & 16.7 & 254.8 & 80.2 & 84.1 & 92.4 \\
\hline $13: 40$ & 2 & 14 & 150.1 & 14.9 & 180.9 & 16.1 & 228.3 & 75.8 & 80.7 & 87.2 \\
\hline $11: 40$ & 2 & 14.1 & 153.3 & 15 & 184.6 & 16.7 & 254.8 & 76.3 & 81.2 & 90.4 \\
\hline $13: 50$ & 2 & 14.1 & 153.3 & 14.7 & 173.8 & 16.4 & 241.3 & 74.8 & 78.0 & 87.0 \\
\hline $11: 50$ & 2 & 14.7 & 173.8 & 15.4 & 199.8 & 16.5 & 245.7 & 76.0 & 79.6 & 85.3 \\
\hline $16: 40$ & 2 & 15.4 & 199.8 & 16.4 & 241.3 & 18.1 & 324.4 & 78.4 & 83.5 & 92.2 \\
\hline $10: 50$ & 2 & 16.3 & 236.9 & 17.6 & 298.2 & 18.9 & 369.3 & 79.9 & 86.2 & 92.6 \\
\hline $18: 40$ & 2 & 16.7 & 254.8 & 17.1 & 273.5 & 18.4 & 340.8 & 81.4 & 83.4 & 89.7 \\
\hline $17: 40$ & 2 & 16.7 & 254.8 & 17.8 & 308.5 & 19.4 & 399.4 & 80.3 & 85.6 & 93.3 \\
\hline $16: 50$ & 2 & 16.2 & 232.6 & 17.1 & 273.5 & 18 & & 77.9 & 82.2 & 87.5 \\
\hline $10: 40$ & 2 & 17.7 & 303.3 & 18.4 & 340.8 & 20.9 & 499.4 & 83.2 & 86.4 & 98.2 \\
\hline $18: 50$ & 2 & 17.2 & 278.3 & 18.4 & 340.8 & 20.8 & 492 & 80.1 & 85.7 & 96.8 \\
\hline $17: 50$ & 2 & 17.1 & 273.5 & 18.2 & 329.8 & 19.9 & 431.1 & 78.9 & 84.0 & 91.8 \\
\hline $09: 40$ & 2 & 19.4 & 399.4 & 20.1 & 444.2 & 22.8 & 648.3 & 79.5 & 82.4 & 93.5 \\
\hline $09: 50$ & 2 & 20.7 & 485.2 & 21.6 & 551.2 & 23. 1 & 674.3 & 79.2 & 82.6 & 88.3 \\
\hline Mean: & & 15.6 & 219.2 & 16.5 & 258.0 & 18.1 & 340.9 & 78.5 & 83.1 & 91.1 \\
\hline Ratio \% & & 94.4 & 84.1 & 94.7 & 84.4 & 99.4 & 97.5 & 94.0 & 94.4 & 99.1 \\
\hline
\end{tabular}

page 2 of 3 
Table 3-3.a Jess-C Blockbuster Test Analysis

Row Downwind of Test Row; (16 RD Downwind)

\begin{tabular}{|c|c|c|c|c|c|c|c|}
\hline $\begin{array}{l}\text { Time } \\
\text { Of Day }\end{array}$ & $\begin{array}{l}\text { ROWS ON } \\
\text { UPWIND }\end{array}$ & $\begin{array}{c}\text { M09 } \\
\text { energy }\end{array}$ & $\begin{array}{l}\text { M10 } \\
\text { energy }\end{array}$ & $\begin{array}{l}\text { M11 } \\
\text { energy }\end{array}$ & $\begin{array}{l}\text { M12 } \\
\text { energy }\end{array}$ & $\begin{array}{c}\text { M13 } \\
\text { energy }\end{array}$ & $\begin{array}{l}\text { SUM OF } \\
\text { M09-M13 }\end{array}$ \\
\hline $\begin{array}{l}16: 10 \\
15: 10 \\
13: 10 \\
13: 20 \\
16: 20 \\
15: 20 \\
12: 20 \\
4: 20 \\
1: 20 \\
1: 10 \\
2: 10 \\
4: 10 \\
8: 20 \\
7: 20 \\
8: 10 \\
7: 10 \\
0: 20 \\
0: 10 \\
9: 10 \\
9: 20 \\
\text { lean: }\end{array}$ & $\begin{array}{l}1 \\
1 \\
1 \\
1 \\
1 \\
1 \\
1 \\
1 \\
1 \\
1 \\
1 \\
1 \\
1 \\
1 \\
1 \\
1 \\
1 \\
1 \\
1 \\
1\end{array}$ & $\begin{array}{r}2 \\
2 \\
1.9 \\
1.9 \\
2 \\
1.8 \\
2.3 \\
2.8 \\
2.6 \\
2.6 \\
2.7 \\
2.7 \\
3.4 \\
3.4 \\
3.8 \\
3.6 \\
5 \\
5 \\
5.6 \\
5.7 \\
3.1\end{array}$ & $\begin{array}{l}1.9 \\
1.7 \\
1.7 \\
1.6 \\
1.8 \\
1.8 \\
2.1 \\
2.6 \\
2.7 \\
2.5 \\
2.3 \\
2.4 \\
3.3 \\
3.6 \\
3.6 \\
4.8 \\
5.1 \\
5.7 \\
5.7 \\
3.0\end{array}$ & $\begin{array}{r}2 \\
1.7 \\
1.8 \\
1.5 \\
1.9 \\
1.9 \\
2.1 \\
2.6 \\
2.7 \\
2.8 \\
2.2 \\
2.7 \\
3.2 \\
3.3 \\
3.6 \\
3.4 \\
5.7 \\
5.7 \\
6 \\
5.8 \\
3.1\end{array}$ & $\begin{array}{r}2 \\
1.7 \\
1.7 \\
1.5 \\
2.2 \\
1.9 \\
2.2 \\
2.5 \\
2.6 \\
2.8 \\
2.1 \\
3.1 \\
3.4 \\
3.1 \\
3.6 \\
3.5 \\
5.5 \\
5.9 \\
5.5 \\
5.7 \\
3.1\end{array}$ & $\begin{array}{r}2.7 \\
2 \\
1.8 \\
2.6 \\
2.8 \\
2.2 \\
2.7 \\
3 \\
0 \\
1.9 \\
2.5 \\
3.8 \\
4.5 \\
4.3 \\
4.9 \\
6 \\
6.4 \\
6.1 \\
6.1 \\
3.5\end{array}$ & $\begin{array}{r}10.6 \\
9.1 \\
8.9 \\
9.1 \\
10.7 \\
9.6 \\
11.4 \\
13.5 \\
10.6 \\
12.6 \\
11.8 \\
14.9 \\
16.8 \\
17.5 \\
18.9 \\
19 \\
27 \\
28.1 \\
28.9 \\
29 \\
15.9\end{array}$ \\
\hline $\begin{array}{l}12: 50 \\
15: 40 \\
15: 50 \\
14: 40 \\
12: 40 \\
14: 50 \\
13: 40 \\
11: 40 \\
13: 50 \\
11: 50 \\
16: 40 \\
10: 50 \\
18: 40 \\
17: 40 \\
16: 50 \\
10: 40 \\
18: 50 \\
17: 50 \\
09: 40 \\
09: 50 \\
\text { Mean: }\end{array}$ & $\begin{array}{l}3 \\
3 \\
3 \\
3 \\
3 \\
3 \\
3 \\
3 \\
3 \\
3 \\
3 \\
3 \\
3 \\
3 \\
3 \\
3 \\
3 \\
3 \\
3 \\
3\end{array}$ & $\begin{array}{l}1.5 \\
1.6 \\
1.5 \\
1.8 \\
1.6 \\
2.3 \\
1.7 \\
1.8 \\
1.6 \\
2.1 \\
2.5 \\
2.9 \\
2.7 \\
2.7 \\
3.1 \\
3 \\
3.1 \\
3.2 \\
4.4 \\
5.3 \\
2.5\end{array}$ & $\begin{array}{l}1.5 \\
1.5 \\
1.6 \\
1.6 \\
1.5 \\
2.1 \\
1.5 \\
1.5 \\
1.5 \\
1.8 \\
2.1 \\
2.5 \\
2.7 \\
2.6 \\
2.6 \\
3.1 \\
2.8 \\
2.8 \\
4.2 \\
5.4 \\
2.3\end{array}$ & $\begin{array}{l}1.5 \\
1.6 \\
1.5 \\
1.7 \\
1.6 \\
1.9 \\
1.7 \\
1.8 \\
1.8 \\
1.9 \\
2.6 \\
3.2 \\
2.9 \\
3.2 \\
2.7 \\
3.5 \\
3.2 \\
3.1 \\
4.5 \\
5.7 \\
2.6\end{array}$ & $\begin{array}{r}1.4 \\
1.7 \\
1.8 \\
1.8 \\
2 \\
2.3 \\
2 \\
2.2 \\
2.1 \\
1.9 \\
2.6 \\
3.6 \\
3.3 \\
3.5 \\
2.9 \\
4.2 \\
3.8 \\
3.5 \\
4.2 \\
5.7 \\
2.8\end{array}$ & $\begin{array}{r}1.7 \\
2.5 \\
2.2 \\
2.4 \\
2.7 \\
3.3 \\
2.3 \\
0.5 \\
2.8 \\
2.7 \\
4 \\
4 \\
3.7 \\
4.1 \\
3.4 \\
5.6 \\
4.8 \\
5 \\
5 \\
6.7 \\
3.5\end{array}$ & $\begin{array}{r}7.6 \\
8.9 \\
8.6 \\
9.3 \\
9.4 \\
11.9 \\
9.2 \\
7.8 \\
9.8 \\
10.4 \\
13.8 \\
16.2 \\
15.3 \\
16.1 \\
14.7 \\
19.4 \\
17.7 \\
17.6 \\
22.3 \\
28.8 \\
13.7\end{array}$ \\
\hline atio & $(\%)$ & 80.3 & 78.4 & 82.4 & 90.4 & 98.7 & 86.4 \\
\hline
\end{tabular}

page 3 of 3 
JESS-C BLOCKBUSTER TEST SEPT 25,1987

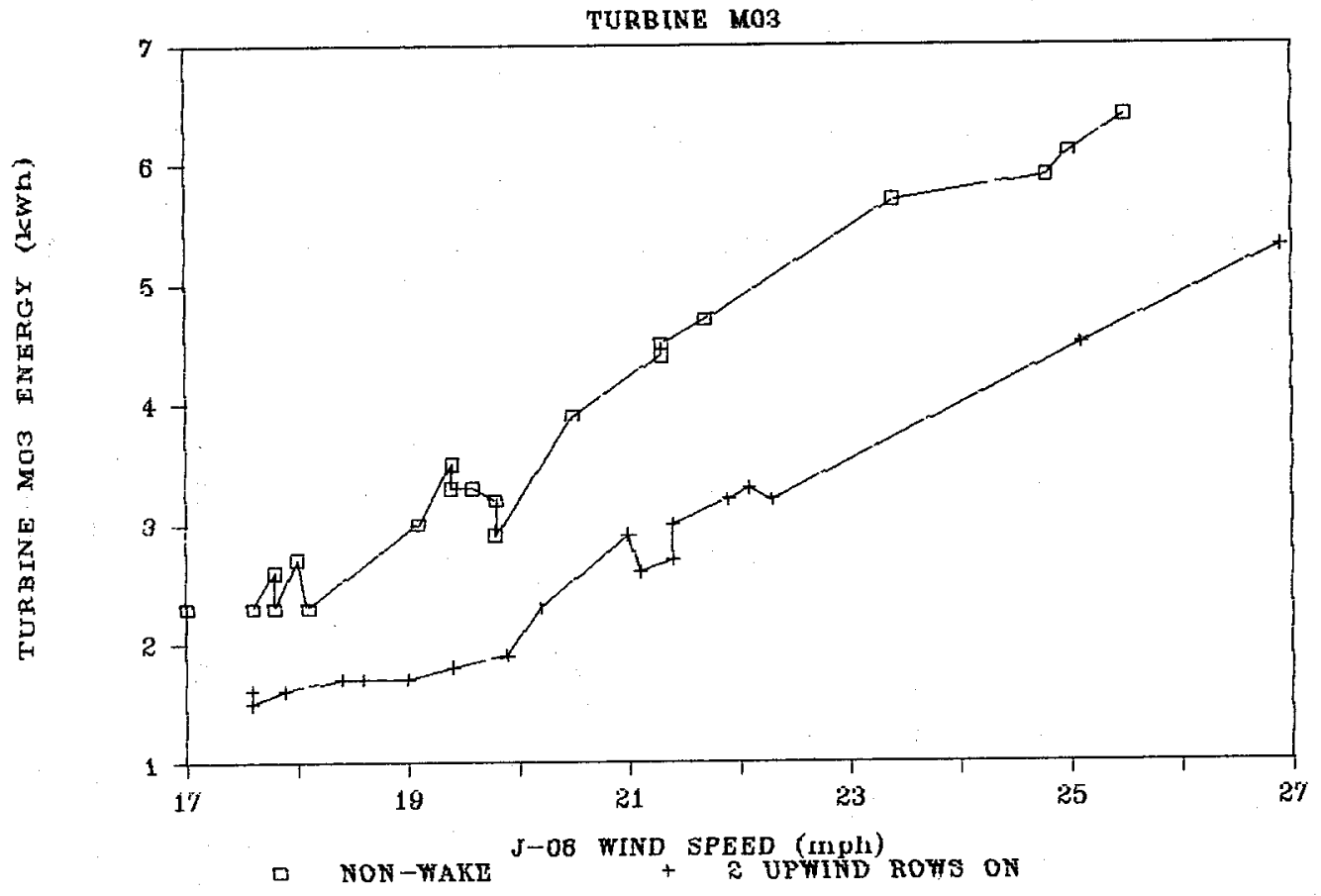

JESS-C BLOCKBUSTER TEST SEPT 25,1987

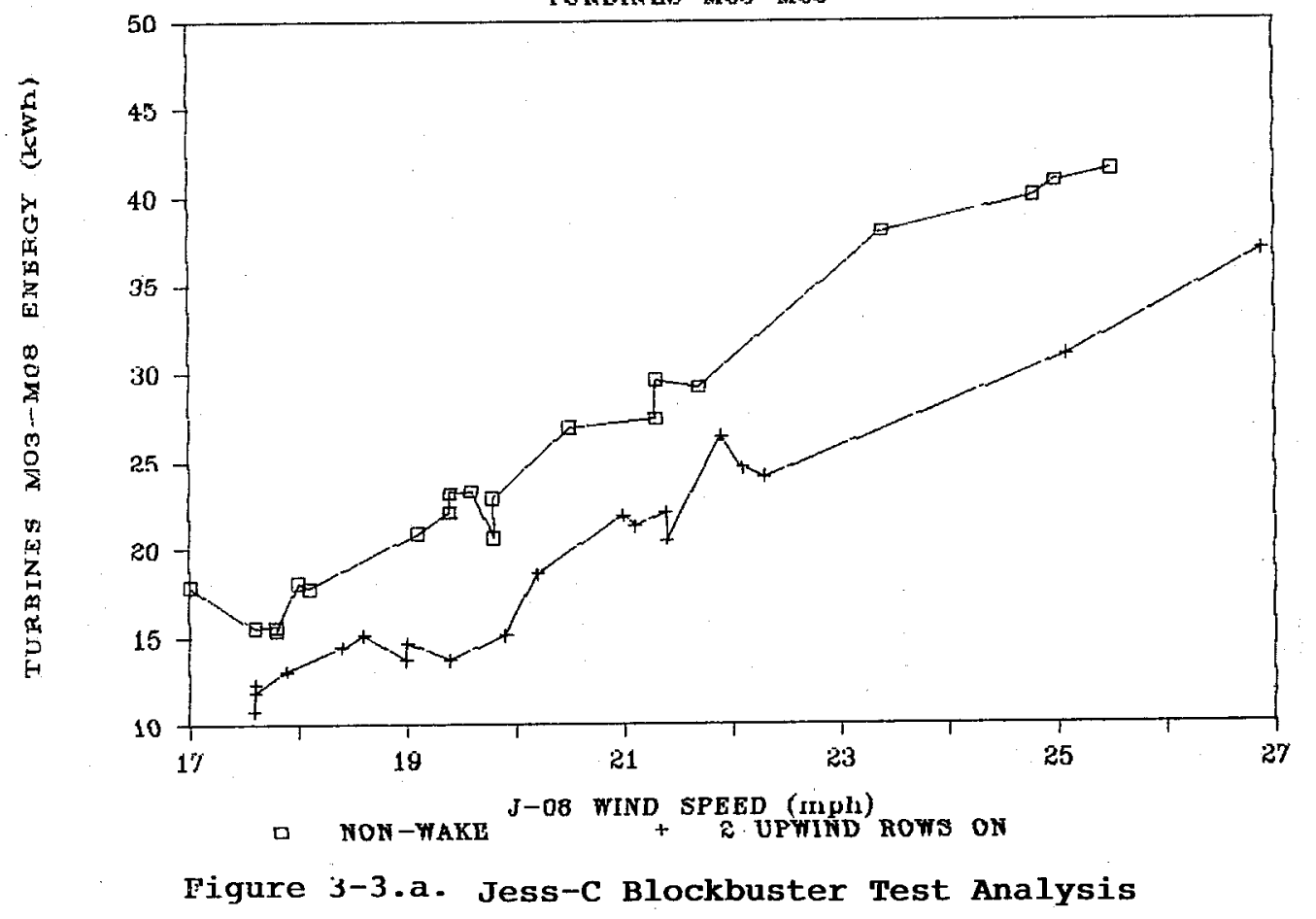


The lower half of the figure is a plot of $J 08$ wind speed versus energy production for the entire turbine string of M03 through M08. The data is similar to the upper half of the figure except that the lines diverge slightly, indicating slight increases in the absolute deficits at higher winds. Thus the deficit is fairly constant on a percentage basis.

The second analysis is on page 2 of Table 3-3.a. This is the wind speed data from turbine anemometers M04, M06, and M08. Wind power density, in W/m ${ }^{2}$ was calculated for each $10-\mathrm{min}$ wind speed record. Speed ratios to J08 were also calculated. The upper half of the page is for nonwake periods, and the lower half is for wake periods. At the bottom of the page, ratios were calculated between the two period means as in all the other tables. The table shows that the wind speed deficits were very small compared to the energy deficits. For example, turbine M04 had an energy deficit of $33.3 \%$ and a speed deficit of only $5.6 \%$. Power density deficits were between the speed and energy deficits. For example, the M04 power density deficit was $15.9 \%$. The large difference between the energy deficits and the speed and power density. deficits could come from two sources. First, the anemometer is at $35 \mathrm{ft}$ agl and the turbine hub-height is $72 \mathrm{ft}$ agl. The wake may not have spread vertically and could be worse at hub-height than at $35 \mathrm{ft}$. Second, wake turbulence from the upstream turbines could have different effects on a turbine and cup anemometer. Turbulence could have a negative effect on power output but could cause overspeeding of the cup, a positive effect.

The third analysis is the calculation of speed ratios to J08. It is interesting to compare these to the free-flow speed ratios. The free-flow ratios were $84 \%, 91 \%$, and $96 \%$ at turbines M04, M06, and M08, respectively. During this test, the ratios were $84 \%, 88 \%$, and $92 \%$ during the nonwake period and $79 \%, 83 \%$, and $91 \%$ during the wake period.

The last analysis is on page three of Table 3-3.a. In this table, the energy production from the next row downwind was examined. Although they are not in the Jess-C array, turbines M09 through M13 were analyzed in the same fashion as M03 through M08. Bear in mind that these turbines are about $16 \mathrm{D}$ and $24 \mathrm{D}$ downwind of the two turbine rows that were switched on and off, and 8 D downwind of the principal test row. Therefore, this analysis studies the incrementa1 wake effects of going from one row on-1ine that is 8 D upwind, to three rows on-line that are 8,16 and $24 \mathrm{D}$ upwind. The energy deficits are still quite large in this row, and the pattern within the row is the same. The northern turbine closest to Interstate 580, M13, has almost no deficit. At the other end of the string, turbine M09 has a deficit of $19.7 \%$. The mean deficit in this row was $13.6 \%$, which is about $55 \%$ of the deficit of the M03-M08 row. Together, these two test rows experienced a mean energy deficit of $19.1 \%$.

Figure 3-3.b is a plot of the individual turbine wake deficits measured at the two rows on the Jess Ranch. This figure is similar to Figure 3-1.a except that the scale of the wake bar is different.

\subsubsection{Test 2 Analysis, Souza-C, October 7, 1987}

Table 3-3.b 1ists the data for the test that took place on Souza-C on October 7, 1987. The table shows that the mean speeds at the upwind anemometer were about $28 \mathrm{mph}$ from the southwest. More than half the 10-min 


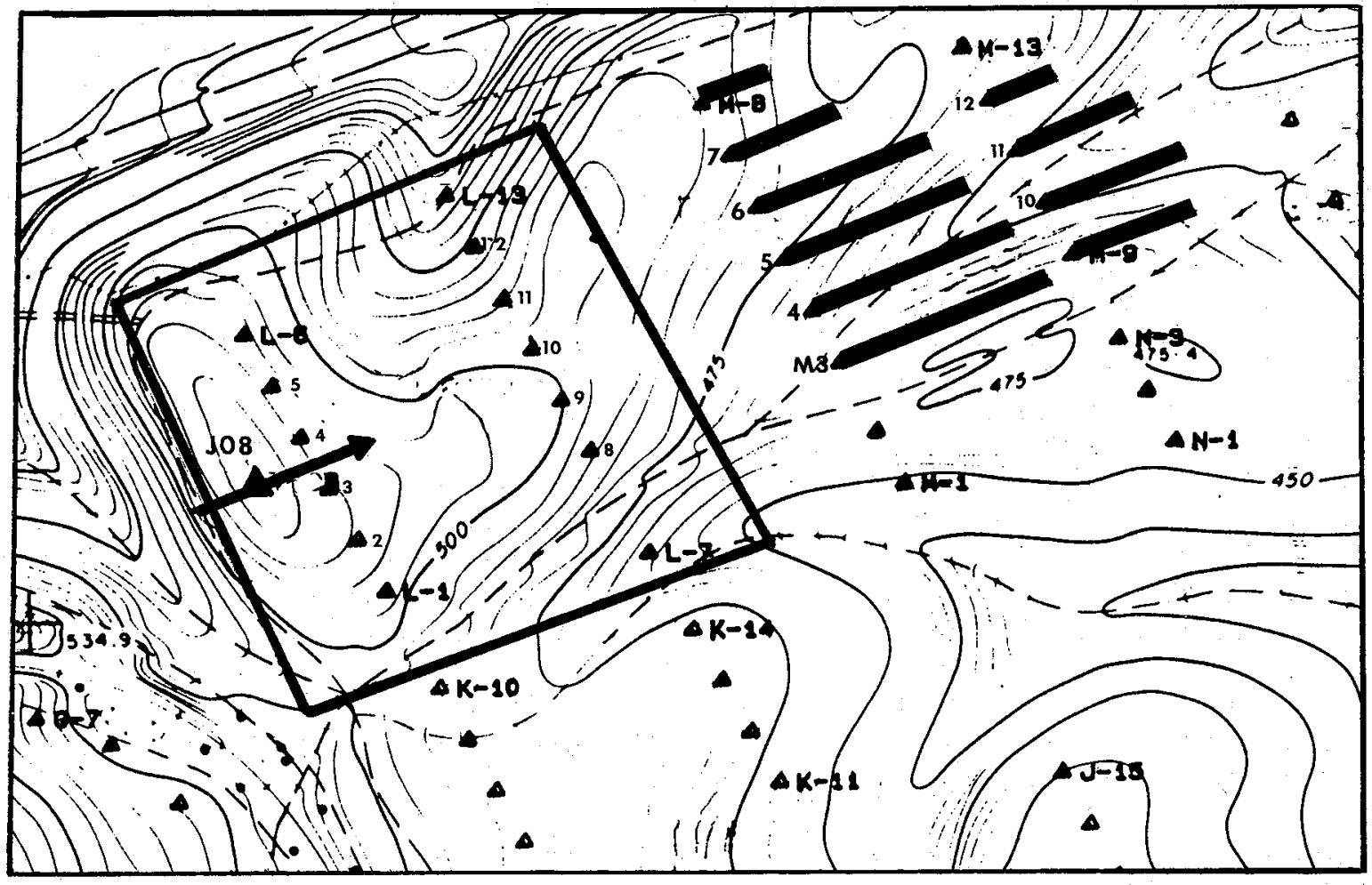

Figure 3-3.b. Jess-C Blockbuster Test Individual Turbine Deficits

Sept 25, 1987 test conditions at reference anemometer, J-08: mean speed $=19.8 \mathrm{mph}$, mean direction $=250$ degrees.

$\mathrm{KEY}$

$\Delta \Delta \quad=$ turbines switched on and off

$=\%$ wake energy deficit, $1^{\prime \prime}=30 \%$

Deficits

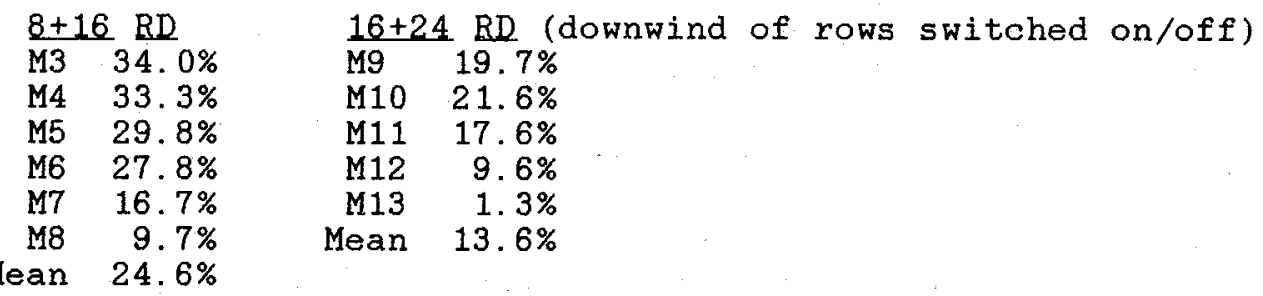


Table 3-3.b Souza-C Blockbuster Iest Analysis

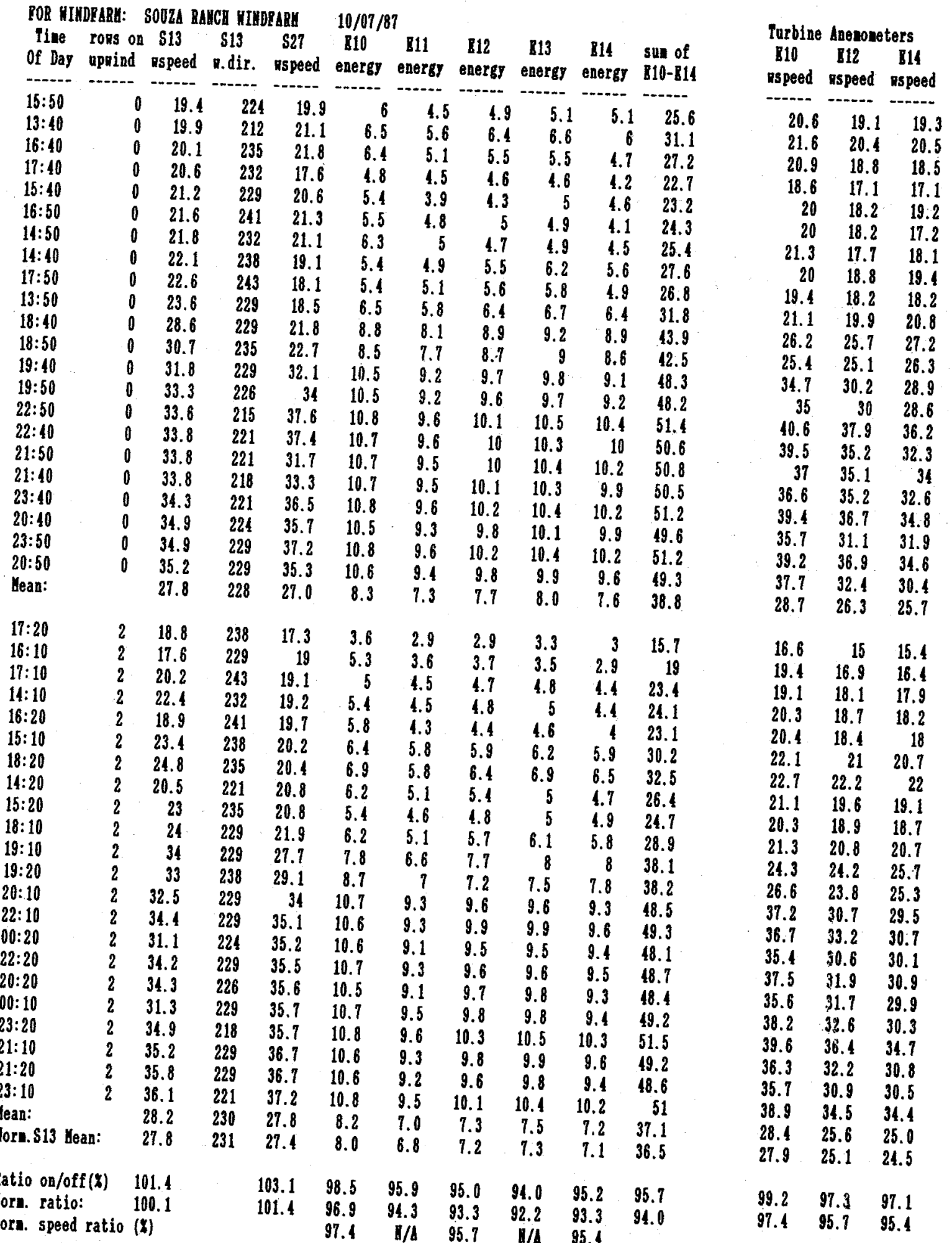


records had wind speeds above $30 \mathrm{mph}$. Recall that the Nordtank power curve becomes less steep at this speed and that smaller deficits are expected in these high speeds. The $16 \mathrm{D}$ data analysis also suggested that in winds above $31 \mathrm{mph}$, negligible deficits could be expected from the more distant row. This mean speed is considerably higher than the test conducted on Jess and discussed previously. It should be noted that turbine $F 4$ in the first row of turbines, and one of the 12 to be switched on and off, was not operational during this test.

Because the mean speeds for the two test periods at the upwind reference anemometer had a half-mph difference, a second set of means was calculated to eliminate this possible source of bias. The second set of ratios between periods uses these means (see line "Norm. ratio:"). The energy deficits were much smaller during this test than during the test conducted on Jess. The mean energy ratio of the five test turbines was $94.0 \%$, which is equivalent to a $6.0 \%$ energy deficit. The pattern within the row was the same as it was during the Direct Wake Tests with the smallest deficits at E10 and increasing to E13 and E14. Wind speed data from turbines E10, E12, and E14 showed speed deficits of $2.6 \%$ to $4.6 \%$. These speed deficits are consistent with the $6.0 \%$ energy deficit as one can square the speed deficit for a crude approximation of the energy deficit.

Statistical significance of the mean row deficit was only 0.70 . This is not a very high confidence level. At turbine E13, which had the greatest deficit, the significance level was 0.80 .

The likely explanation for these relatively low energy deficits is the higher winds. Recall that on the Jess Ranch test, the mean wind speed was $\sim 20 \mathrm{mph}$ at J08 and 15 to $18 \mathrm{mph}$ at the turbine anemometers, versus $\sim 28 \mathrm{mph}$ during this test on Souza. Although not shown on Table $3-3 . b$, the data were divided into subsets, and a low wind speed subset was calculated based on the records with wind speeds below $30 \mathrm{mph}$. The mean speeds for the two test subperiods were about $23 \mathrm{mph}$ at $\mathrm{S} 13$ and $22 \mathrm{mph}$ at the turbine anemometers. The mean energy ratio for the five test turbines was $88.0 \%$, which is equivalent to an energy deficit of $12.0 \%$. This is exactly twice as high as the $6.0 \%$ deficit measured in the higher wind speeds. Recal1 that in the $16 \mathrm{D}$ tests, it appeared that the wake energy deficits were more sensitive to changes in speed than in the $8 \mathrm{D}$ tests, and that negligible deficits were expected above $31 \mathrm{mph}$. The Blockbuster Test employs both the $8 \mathrm{D}$ and $16 \mathrm{D}$ rows simultaneously. Thus the deficits may also have a higher sensitivity to wind speed than the direct wake tests.

\subsubsection{Summary}

Two Blockbuster Tests were conducted: one at Jess-C and one at Souza-C. The wake deficits measured during the two tests were quite different. In the first test, mean speeds were quite $10 \mathrm{w} \mathrm{--} \mathrm{about} 20 \mathrm{mph}$ at J08 and $15 \mathrm{mph}$ to $18 \mathrm{mph}$ at the test turbines. The energy deficits were enormous -- about $25 \%$ for the row average. The maximum individual deficit was $34 \%$. In the second test, wind speeds were much higher, about $28 \mathrm{mph}$ at $\mathrm{s} 13$ and $25 \mathrm{mph}$ to $28 \mathrm{mph}$ at the turbine anemometers. The energy deficits were much lower than the first test - $6 \%$ for the row average. The maximum individual deficit was about $8 \%$. The large difference in mean speeds, approximately $10 \mathrm{mph}$, is believed to be the principal reason for the large difference in the deficits 
-- $25 \%$ versus $6 \%$. The inverse relationship between speed and energy deficits, seen in the direct wake and sixteen-diameter tests, was evident here as we11. This inverse relationship was also responsible for the variation in individual turbine deficits within the test rows. Turbines at lower elevation sites, with lower energy output (1ower winds) experienced higher energy deficits. No attempt has been made to try to normalize these terrain effects on wake deficits.

\subsection{Multiple Row Wake Effect Test}

The Multiple Row Wake Effect Test was designed to measure the incremental effects of several rows of turbines. Energy production in the downwind row is compared for periods when $0,1,2$, or 3 upwind rows are on line. In addition to the analysis of the downwind row, the data from the middle row(s) are analyzed as well. In a three row test group, data collected in the middle row are analyzed exactly the same as in the Direct Wake Test. In the middle row analysis, the data collected while it is on line are sorted into two time groups, when the front row was on 1 ine or off. Additional discussion on test methodology can be found in Section 2.4. Three Multiple Row Wake Tests were conducted on:

1. Jess-C ( 3 rows), September 4, 1987, 13:30-21:10 PDT ( $8 \mathrm{~h}$ )

2. Jess-A ( 4 rows), September $10,1987,13: 50-24: 00$ PDT (10 h)

3. Souza-C ( 3 rows), October 9, 1987, 10:30-23:10 PDT (12 h)

Buffer turbines were used in the first two tests but not in the third.

\subsubsection{Test 1 Analysis, Jess-C, September 4, 1987}

Tables 3-4.a and 3-4.b are the data listings for the back and middle rows for the September 4 test on Jess-C. A complete description of the data format can be found on page 11. Table 3-4.a shows that the mean wind speed at the upwind reference tower was about $30 \mathrm{mph}$ from the west-southwest. The Nordtank power curve begins to flatten out at this speed. Mean speeds at the turbine anemometers ranged from $24 \mathrm{mph}$ to $28 \mathrm{mph}$. The three period means show that there was about a $1 \%$ difference in mean speeds between the periods, which introduces a slight bias. To reduce this bias, a second set of means was calculated for the third data period: two upwind rows on. The table shows that the mean speed for this "normalized" period was $29.7 \mathrm{mph}$, which is the same as the first period. Thus, the bias is reduced.

At the bottom of Table 3-4.a there are several sets of energy and speed ratios, one showing the effects of one row, and the other two showing the effects of two rows. One set of ratios uses all the data, and the last set of ratios uses the "normalized" data set. The mean ratio, which excludes M8, shows a $5.4 \%$ drop in energy for the period when one row was turned on and only an additional $1.7 \%$ decrease during the period when the second row was turned on ("normalized" data set). However, inspection of the individual turbines reveals that a pattern seen earlier was present. Turbine M8, at the northern edge of the array, had little or no deficits in either period. At the other end of the row, at turbines $M 4$ and $M 5$, there were $5 \%$ to $7 \%$ deficits when the first row was on and an additional $2 \%$ to $4 \%$ deficit when the second upwind row was turned on. Some of the probable reasons for this pattern (i.e., terrain 
Table 3-4.a Jess-C lultiple ror gake test analysis

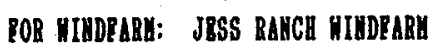

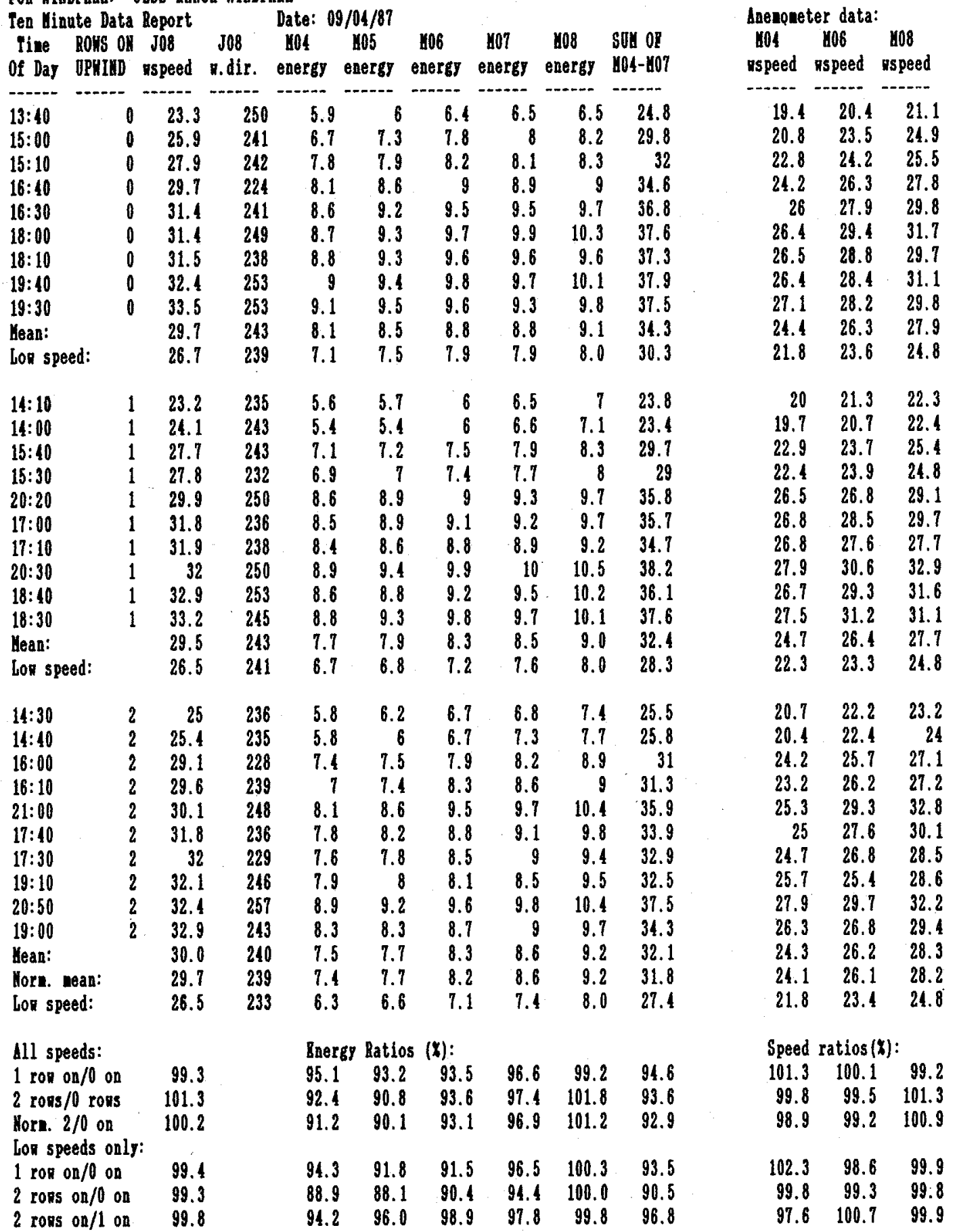


Table 3-4.6 Jess-C Viddle Ron Analysis, Multiple Ron Test

Fen Uinute Data Report

POR NIHDPARH: JBSS RANCH NINDPARY

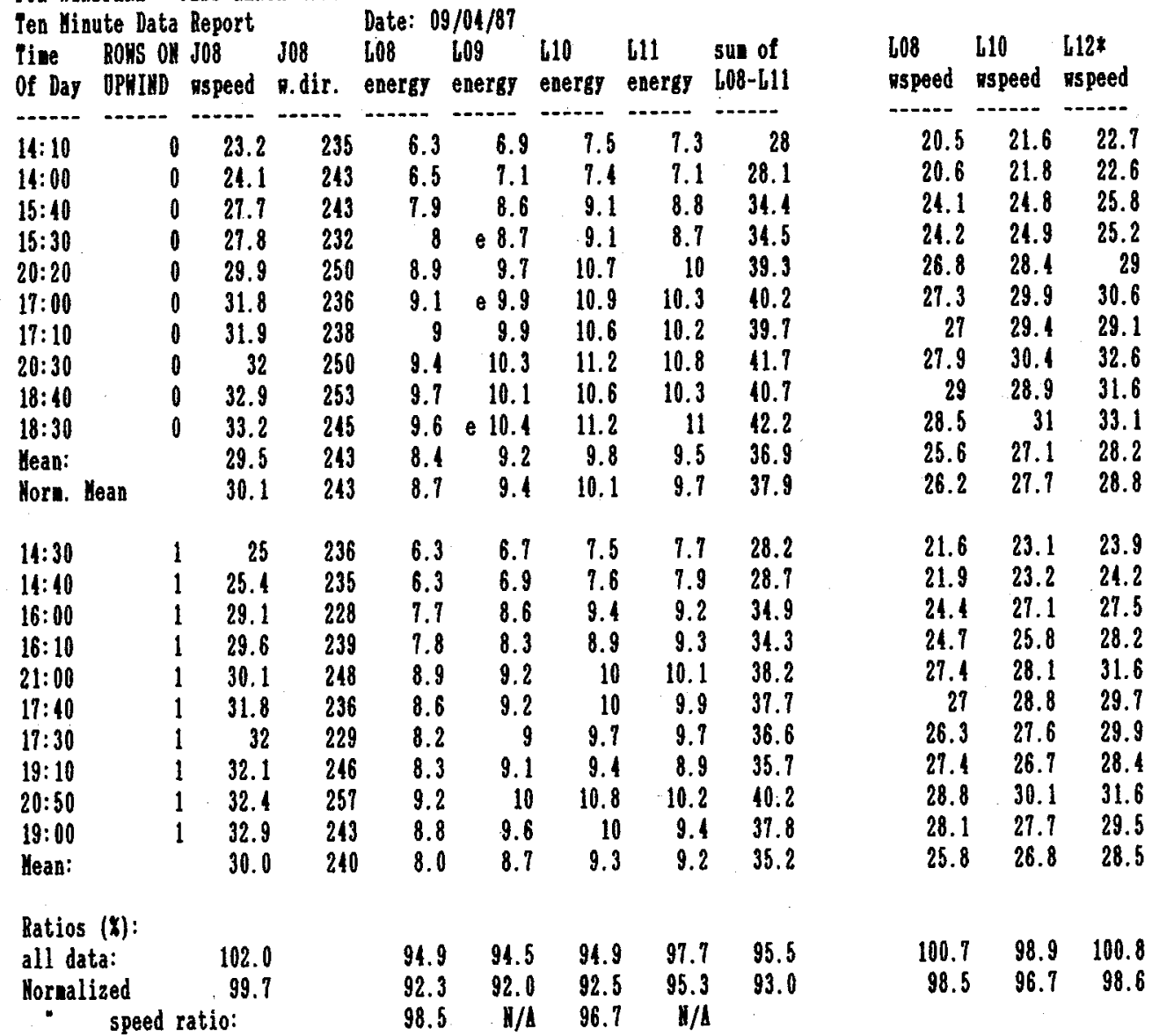

* Hote: $L 12$ speeds valid, although turbine not operational $\theta=$ estinate, 49 off-line for portion of 10 -ainute period 
effects and wake trajectory) have been discussed in previous sections. In addition, there may have been problems with turbine L12 (see last paragraph on this page), which is upwind of M8.

Analysis of the turbine anemometer data shows negligible speed deficits at all three turbines.

Statistical significance levels for this test were 0.80 for one row on versus none on, and 0.75 for two rows on versus none. Turbine M5, with the highest energy deficit, had higher significance levels for the two rows on versus none: 0.90 .

Some additional analysis was done to examine the wake deficits at lower wind speeds. Recall that the $16 \mathrm{D}$ test data in Section 3.2 suggested that the wake deficit from the more distant ( $16 \mathrm{D})$ row was more sensitive to changes in speed than the closer $(8 \mathrm{D})$ row. The analysis also showed that negligible deficits were expected above $31 \mathrm{mph}$ from the distant row. Therefore only samples with mean speeds below $30 \mathrm{mph}$ at J08 were used. The mean speed at J08 for these lower speed subsets was about $26 \mathrm{mph}$. Ratios were calculated for the three low speed data sets, and the results are different from those discussed in the paragraph above. With one upwind row on, the mean ratio at turbines M4 through M7 was $93.5 \%$, which is equivalent to a deficit of $6.5 \%$. When the second upwind row was switched on, the mean energy ratio was $90.5 \%$, which is equivalent to an energy deficit of $9.5 \%$. Thus the incremental energy deficit for the second upwind row is 3\%, which is almost a $50 \%$ incremental increase above the single row deficit. This is a much larger incremental increase than is seen in the entire data set with the higher wind speeds. A third line of low speed ratios ("2 on/I on") displays these incremental energy ratios. The pattern within the row is consistent with other test results. The largest deficits were at $\mathrm{M4}$, and the lowest deficits were at M8. The results of this lower wind speed analysis are in agreement with the 16 D test data. Specifically, the analysis shows that the incremental wake deficit from the more distant (16 D) row is much more pronounced in winds below $30 \mathrm{mph}$.

The individual turbine deficits are plotted in Figure 3-4.a. The deficits are plotted parallel to the wind direction at each turbine. The deficits from the first row are plotted as solid black bars. The deficits from the second row are plotted as open rectangles extending from the bars. There are two separate maps. The upper map shows the deficits for the entire data set. The lower map shows the deficits for the lower speed subset, which used the samples with wind speeds below $30 \mathrm{mph}$. The figure shows the increase in deficits in the lower speed subset, and shows that the increase is more substantial in the two-row deficit. The figure shows that turbine M5, which had the largest deficits, is downwind of the center of the two upwind rows.

Table $3-4 . b$ is the analysis of the middle row and is the same as a direct wake test analysis. The data from turbine $L 12$ were rejected from the data set because the energy values looked very low, around $1 \mathrm{kWh}$ per 10 -min period. It is not clear if turbine production was actually that low or if there was a problem with communication. In addition, there were three data periods when turbine 49 faulted and was manually restarted 2 to 4 min into the data period. The data for these three periods were adjusted based on the energy ratio to turbine L8. The energy ratio to L8 was calculated using the other valid data samples in the same test scenario. 

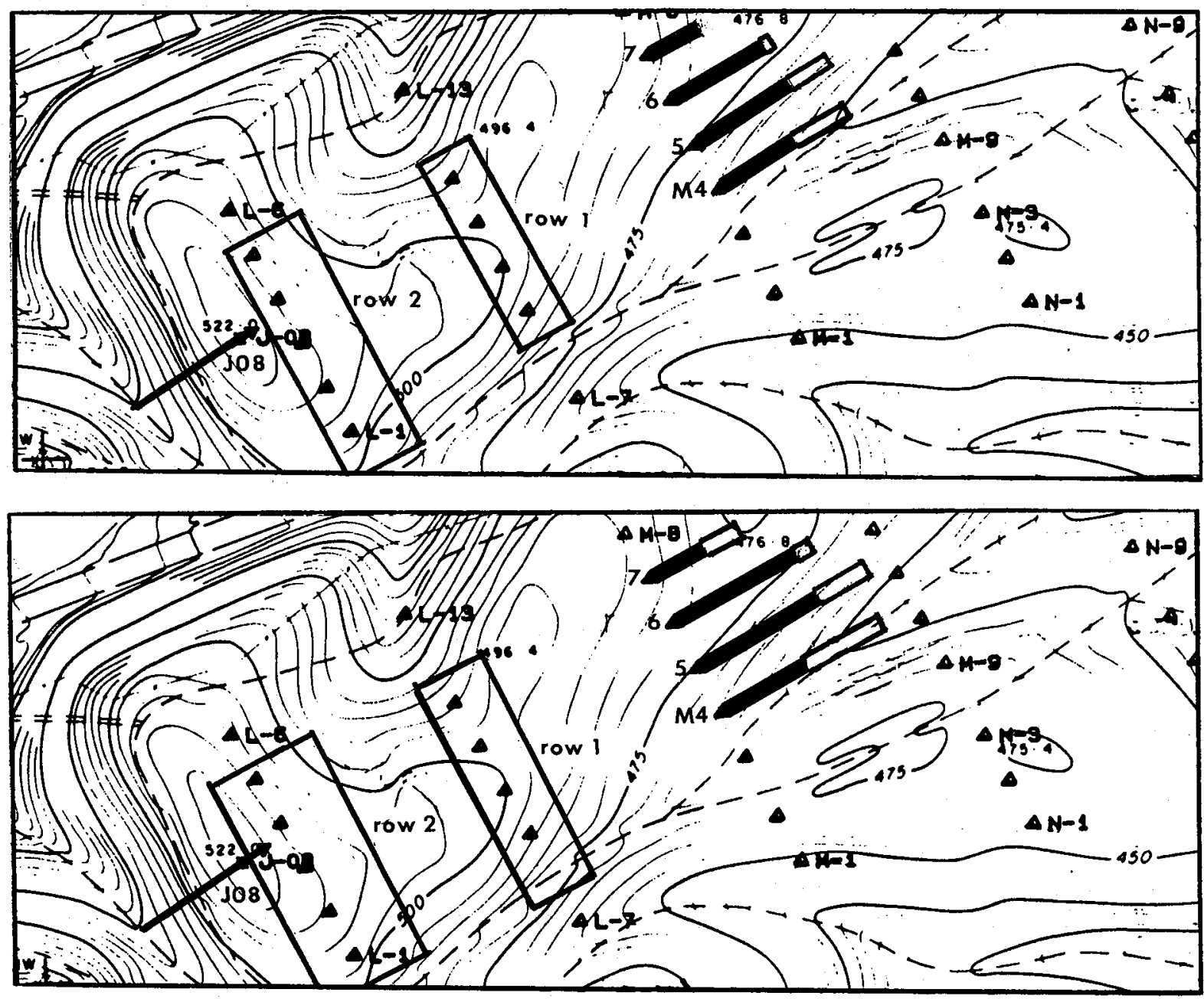

Figure 3-4.a. Jess-C Multiple Row Wake Test Individual Turbine Deficits

Sep 4, 1987 test conditions at reference anemometer;

J-08: mean speed $=29.7 \mathrm{mph}$, mean direction $=237$ degrees, J-08: mean speed $=26.5 \mathrm{mph}$, (low speed dataset)

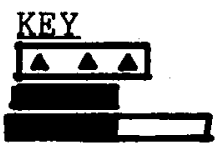

$=$ turbine rows switched on and off

$=\%$ wake energy deficit, 1 row on, $1^{\prime \prime}=10 \%$

$=\%$ wake energy deficit, 2 rows on, $1^{\prime \prime}=10 \%$

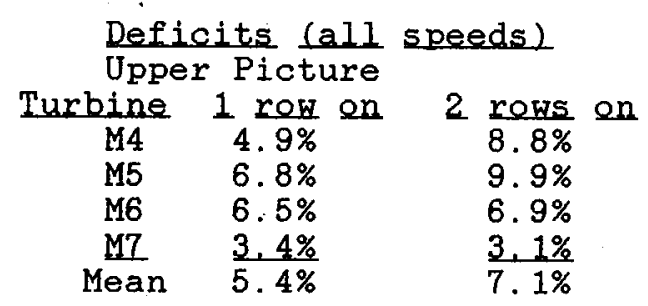

Deficits (low speeds)

Lower Picture

1 row on 2 rows on

$5.4 \%$

$7.1 \%$

$5.7 \%$

$8.2 \%$

$11.1 \%$

$8.5 \%$

11. $9 \%$

$3.5 \%$

$9.6 \%$

$6.5 \%$

$\frac{5.6 \%}{9.5 \%}$ 
Table 3-4.b shows that there was a $1 / 2 \mathrm{mph}$ difference between periods. A second set of means was calculated for the first period to reduce the wind speed bias. The second mean is on the line entitled "Norm. mean" and has a mean speed within $0.1 \mathrm{mph}$ of the other test period. There are two sets of ratios at the bottom of the table, one using all available data and the other entitled "normalized," which uses the second set of means. The "normalized" energy ratio between the two periods was $93.0 \%$, which is equivalent to a $7.0 \%$ energy deficit. The deficit was fairly uniform at turbines L8 through L10, about $7.5 \%$, and a bit lower at L11, about $5 \%$. Statistical significance for the row mean and for $L 9$ were 0.90 .

Speed deficits at the two test turbines were only $1.5 \%$ and $3.3 \%$. The speed and energy deficits were consistent at turbine L10 $(3.3 \%$ and $7.5 \%$, respectively). One would expect the energy deficit to be close to the square of the speed deficit, based on the slope of the Nordtank power curve. At turbine L8 the energy deficit was considerably larger than the speed deficit $(7.7 \%$ versus $1.5 \%)$. There is no apparent reason for this inconsistency, but it could be related to vertical shear or terrain.

\subsubsection{Test 2 Analysis, Jess-A, September 10, 1987}

The Multiple Row Wake Test that took place on September 10 at the Jess-A array was the most elaborate test undertaken during this study. This test involved four rows of turbines, so the analysis is done on three separate rows. Tables 3-4.c, 3-4.d, and 3-4.e list the 10-min data for this test.

Table 3-4.c is the analysis for the back (downwind) row of the group. The table shows that the winds at the J08 anemometer were about $29 \mathrm{mph}$ from the west-southwest. Wind speeds at turbine $\mathrm{K} 3$, not shown on the table, were about $7 \mathrm{mph}$ lower than at J08 throughout the test. There are four periods to compare in this analysis: no upwind rows on versus 1 row on, 2 rows on, and 3 rows on. The table shows that the mean speed at J08 for the no-rows-on period was $27.2 \mathrm{mph}$ versus 28.5 to $29.1 \mathrm{mph}$ for the other three periods. To reduce this bias, the 14:20 observation in the first period was eliminated, and the mean speed for this normalized data set was $28.7 \mathrm{mph}$. At the bottom of the table, three sets of ratios are calculated for the entire data set and for the "normalized" data set described above. The analysis will focus on the latter because the wind speed bias is much lower.

The ratios between periods show some curious results. The energy ratio for the period when the first row of upwind turbines was switched on was $83.3 \%$ for the four-turbine mean. This is equivalent to a $16.7 \%$ energy deficit. The deficit was worse at the southern end of the row, at K11, than at K14. The ratio at $\mathrm{Kll}$ was $74.2 \%$ and the ratios increased steadily to $90.7 \%$ at $\mathrm{K} 14$. The probable explanation for the lower deficit at K14, based on the wind direction data from J08, is that K14 was not in the wake trajectory.

As successive rows of upwind turbines were switched on line, the ratios increased instead of decreasing. This increase occurred at all four turbines and in both periods. The mean ratio for the four turbines, which was $83.3 \%$ with one row on, increased to $86.7 \%$ with two upwind rows on and $94.3 \%$ with three rows on. These ratios are equivalent to energy deficits of $16.7 \%$ for one row, $13.3 \%$ for two rows, and $5.7 \%$ for three upwind rows on. There was no change in mean wind direction at J08 to help explain these energy increases. 
Table 3-4.c Jess-A Multiple Row Wake Test

FOR WINDFARM: JESS RANCH WINDFARM

\begin{tabular}{|c|c|c|c|c|c|c|c|c|}
\hline $\begin{array}{l}\text { Ten Min } \\
\text { Time } \\
\text { of Day }\end{array}$ & $\begin{array}{l}\text { te Data } \\
\text { rows on } \\
\text { upwind }\end{array}$ & $\begin{array}{l}\text { Report } \\
\text { J08 } \\
\text { ws peed }\end{array}$ & $\begin{array}{r}\text { J08 } \\
\text { w. dir. }\end{array}$ & $\begin{array}{l}09 / 10 / 87 \\
\text { K11 } \\
\text { energy }\end{array}$ & $\begin{array}{l}\text { K12 } \\
\text { energy }\end{array}$ & $\begin{array}{l}\text { K13 } \\
\text { energy }\end{array}$ & $\begin{array}{l}\text { K14 } \\
\text { energy }\end{array}$ & $\begin{array}{l}\text { sum of } \\
\mathrm{K} 11-\mathrm{K} 14\end{array}$ \\
\hline $\begin{array}{l}14: 20 \\
14: 10 \\
16: 20 \\
16: 10 \\
12: 10 \\
12: 00 \\
18: 10 \\
18: 20 \\
20: 10 \\
20: 20 \\
22: 20 \\
22: 10\end{array}$ & $\begin{array}{l}0 \\
0 \\
0 \\
0 \\
0 \\
0 \\
0 \\
0 \\
0 \\
0 \\
0 \\
0\end{array}$ & $\begin{array}{l}22.3 \\
22.7 \\
22.9 \\
22.9 \\
25.1 \\
26.3 \\
27.6 \\
28.7 \\
30.0 \\
30.8 \\
33.4 \\
33.6\end{array}$ & $\begin{array}{l}250 \\
243 \\
248 \\
259 \\
245 \\
248 \\
249 \\
252 \\
249 \\
252 \\
253 \\
248\end{array}$ & $\begin{array}{r}4.5 \\
4.8 \\
3.6 \\
4.9 \\
5.8 \\
5.7 \\
7.4 \\
7.6 \\
9.5 \\
8.8 \\
9.6 \\
10.1\end{array}$ & $\begin{array}{l}4.8 \\
5.6 \\
4.3 \\
5.4 \\
6.9 \\
6.8 \\
8.2 \\
8 \\
9.5 \\
9.6 \\
9.9 \\
9.3\end{array}$ & $\begin{array}{r}4.8 \\
5.6 \\
4.9 \\
5 \\
6.6 \\
7 \\
8 \\
7.8 \\
8.6 \\
9.6 \\
10 \\
9.5\end{array}$ & $\begin{array}{l}4.3 \\
5 \\
4.3 \\
4.4 \\
6.1 \\
6.8 \\
7.2 \\
7.7 \\
8.6 \\
9.3 \\
9.8 \\
9.4\end{array}$ & $\begin{array}{r}18.4 \\
21 \\
17.1 \\
19.7 \\
25.4 \\
26.3 \\
30.8 \\
31.1 \\
36.2 \\
37.3 \\
39.3 \\
38.3\end{array}$ \\
\hline last 9 & $\begin{array}{l}\text { mean: } \\
\text { obs. }\end{array}$ & $\begin{array}{l}27.2 \\
28.7\end{array}$ & $\begin{array}{l}249 \\
250\end{array}$ & $\begin{array}{l}6.9 \\
7.7\end{array}$ & $\begin{array}{l}7.4 \\
8.2\end{array}$ & $\begin{array}{l}7.3 \\
8.0\end{array}$ & $\begin{array}{l}6.9 \\
7.7\end{array}$ & $\begin{array}{l}28.4 \\
31.6\end{array}$ \\
\hline $\begin{array}{l}14: 40 \\
14: 50 \\
16: 50 \\
16: 40 \\
12: 40 \\
12: 30 \\
18: 40 \\
18: 50 \\
22: 40 \\
20: 50 \\
22: 50 \\
20: 40\end{array}$ & $\begin{array}{l}1 \\
1 \\
1 \\
1 \\
1 \\
1 \\
1 \\
1 \\
1 \\
1 \\
1 \\
1\end{array}$ & $\begin{array}{l}21.8 \\
23.1 \\
24.4 \\
25.1 \\
26.0 \\
28.1 \\
28.8 \\
29.1 \\
33.2 \\
35.9 \\
36.2 \\
37.2\end{array}$ & $\begin{array}{l}259 \\
255 \\
252 \\
252 \\
245 \\
238 \\
250 \\
248 \\
252 \\
249 \\
246 \\
239\end{array}$ & $\begin{array}{l}4.2 \\
3.2 \\
3.5 \\
2.9 \\
4.9 \\
4.8 \\
6.4 \\
6.6 \\
8.4 \\
8.6 \\
8.7 \\
6.5\end{array}$ & $\begin{array}{l}5.1 \\
4.5 \\
4.2 \\
3.9 \\
6 \\
6.3 \\
8.1 \\
7.4 \\
8.9 \\
7.4 \\
9.1 \\
7.8\end{array}$ & $\begin{array}{l}5.6 \\
4.7 \\
4.4 \\
4.3 \\
6.9 \\
6.7 \\
8.6 \\
7.8 \\
9.4 \\
8 \\
9.4 \\
8.8\end{array}$ & $\begin{array}{l}5.3 \\
4.4 \\
4.2 \\
4 \\
6.8 \\
6.1 \\
8.7 \\
7.7 \\
9.3 \\
8.7 \\
9.3 \\
9.3\end{array}$ & $\begin{array}{r}20.2 \\
16.8 \\
16.3 \\
15.1 \\
24.6 \\
23.9 \\
31.8 \\
29.5 \\
36 \\
32.7 \\
36.5 \\
32.4\end{array}$ \\
\hline & mean: & 29.1 & 249 & 5.7 & 6.6 & 7.1 & 7.0 & 26.3 \\
\hline $\begin{array}{l}15: 20 \\
15: 10 \\
17: 10 \\
13: 10 \\
13: 00 \\
17: 20 \\
19: 10 \\
19: 20 \\
23: 20 \\
21: 20 \\
23: 10 \\
21: 10\end{array}$ & $\begin{array}{l}2 \\
2 \\
2 \\
2 \\
2 \\
2 \\
2 \\
2 \\
2 \\
2 \\
2 \\
2\end{array}$ & $\begin{array}{l}23.7 \\
24.4 \\
25.7 \\
26.4 \\
27.0 \\
27.1 \\
28.4 \\
29.7 \\
31.2 \\
32.9 \\
33.6 \\
34.2\end{array}$ & $\begin{array}{l}262 \\
255 \\
256 \\
243 \\
250 \\
252 \\
246 \\
246 \\
252 \\
248 \\
245 \\
249\end{array}$ & $\begin{array}{r}4.3 \\
4 \\
3.4 \\
4.4 \\
4.5 \\
5 \\
5.9 \\
7 \\
10.5 \\
8.1 \\
7.9 \\
7.5\end{array}$ & $\begin{array}{r}5.5 \\
5 \\
4.5 \\
5.4 \\
6.2 \\
6.8 \\
8.1 \\
8.4 \\
9.6 \\
9.1 \\
7.7 \\
7.9\end{array}$ & $\begin{array}{l}5.4 \\
4.9 \\
5.3 \\
5.7 \\
7.1 \\
7.3 \\
8.4 \\
8.9 \\
8.8 \\
9.5 \\
7.9 \\
8.4\end{array}$ & $\begin{array}{l}5.1 \\
4.5 \\
5.1 \\
5.3 \\
6.5 \\
6.7 \\
8.3 \\
8.7 \\
8.5 \\
9.4 \\
8.1 \\
8.4\end{array}$ & $\begin{array}{r}20.3 \\
18.4 \\
18.3 \\
20.8 \\
24.3 \\
25.8 \\
30.7 \\
33 \\
37.4 \\
36.1 \\
31.6 \\
32.2\end{array}$ \\
\hline & mean: & 28.7 & 250 & 6.0 & 7.0 & 7.3 & 7.1 & 27.4 \\
\hline
\end{tabular}

Page 1 of 2 
Table 3-4.c Jess-A Multiple Row Wake Test

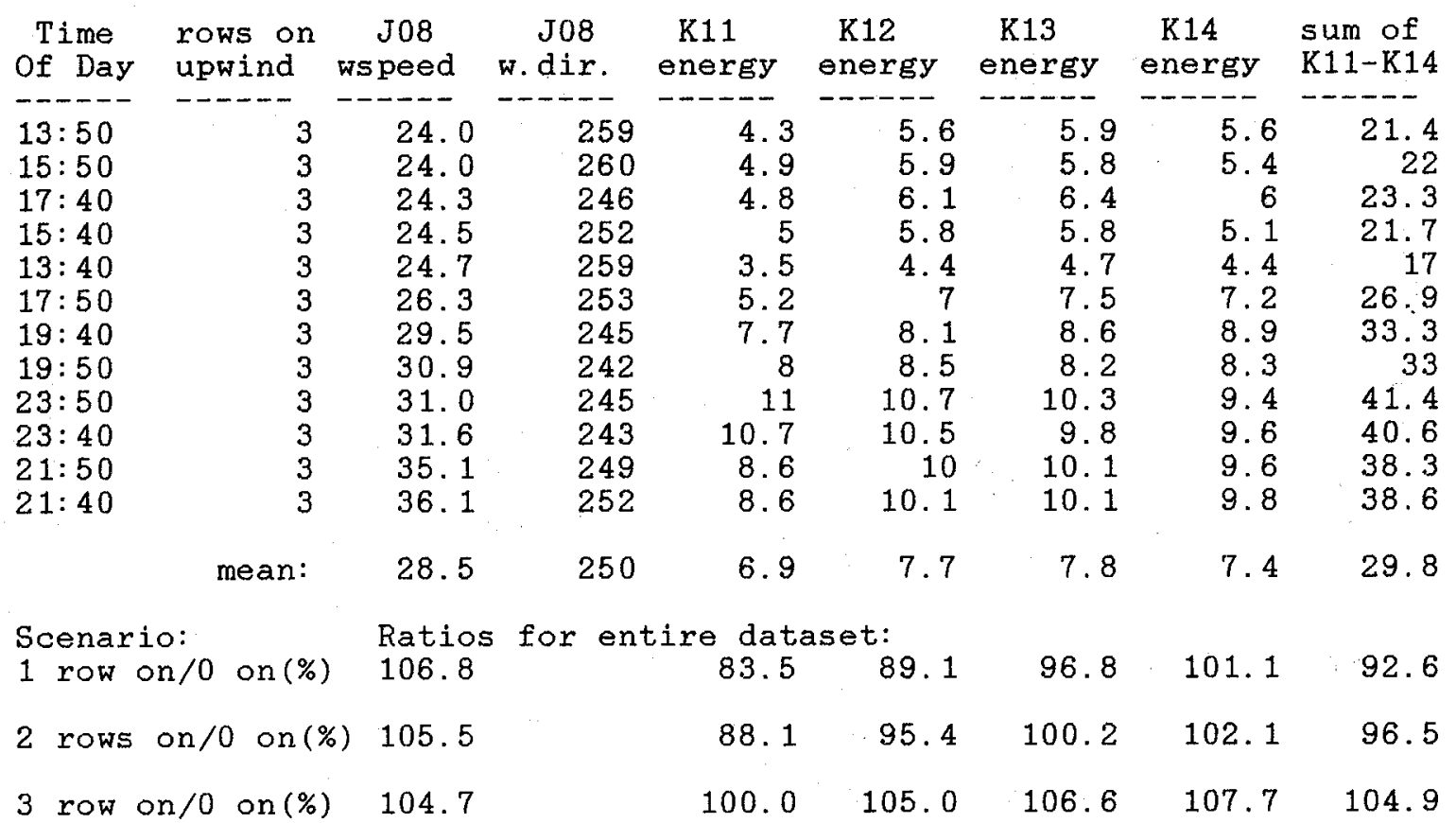

Scenario: Ratios to period normalized for wind speed:

$\begin{array}{lrrrrrr}1 \text { row on } / 0 \text { on }(\%) & 101.2 & 74.2 & 80.2 & 88.0 & 90.7 & 83.3 \\ 2 \text { rows on } / 0 \text { on\% } & 99.9 & 78.4 & 85.8 & 91.1 & 91.6 & 86.7 \\ 3 \text { rows on } / 0 \text { on\% } & 99.2 & 88.9 & 94.5 & 96.9 & 96.6 & 94.3\end{array}$


Table 3-4.d Jess-A Multiple Row Wake Test, Second Row Analysis

FOR WINDFARM: JESS RANCH WINDFARM

\begin{tabular}{|c|c|c|c|c|c|c|c|c|c|}
\hline $\begin{array}{l}\text { Ten Min } \\
\text { Time } \\
\text { of Day }\end{array}$ & $\begin{array}{l}\text { dte Data } \\
\text { rows on } \\
\text { upwind }\end{array}$ & $\begin{array}{c}\text { Report } \\
\text { J08 } \\
\text { wspeed }\end{array}$ & $\begin{array}{l}\text { J08 } \\
\text { ผ. dir. }\end{array}$ & $\begin{array}{l}09 / 10 / 87 \\
\text { K03 } \\
\text { energy }\end{array}$ & $\begin{array}{l}7 \mathrm{K04} \\
\text { energy }\end{array}$ & $\begin{array}{l}\text { K05 } \\
\text { energy }\end{array}$ & $\begin{array}{l}\text { K06 } \\
\text { energy }\end{array}$ & $\begin{array}{l}\text { K07 } \\
\text { energy }\end{array}$ & $\begin{array}{l}\text { sum of } \\
\mathrm{K} 03-\mathrm{K} 07\end{array}$ \\
\hline $\begin{array}{l}14: 40 \\
14: 50 \\
16: 50 \\
16: 40 \\
12: 40 \\
12: 30 \\
18: 40 \\
18: 50 \\
22: 40 \\
20: 50 \\
22: 50 \\
20: 40\end{array}$ & $\begin{array}{l}0 \\
0 \\
0 \\
0 \\
0 \\
0 \\
0 \\
0 \\
0 \\
0 \\
0 \\
0\end{array}$ & $\begin{array}{l}21.8 \\
23.1 \\
24.4 \\
25.1 \\
26.0 \\
28.1 \\
28.8 \\
29.1 \\
33.2 \\
35.9 \\
36.2 \\
37.2\end{array}$ & $\begin{array}{l}259 \\
255 \\
252 \\
252 \\
245 \\
238 \\
250 \\
248 \\
252 \\
249 \\
246 \\
239\end{array}$ & $\begin{array}{r}4.6 \\
3.3 \\
4.8 \\
3.3 \\
5.4 \\
4.9 \\
7.5 \\
7.6 \\
9.4 \\
10.5 \\
9.9 \\
9.8\end{array}$ & $\begin{array}{l}4.3 \\
2.8 \\
4.3 \\
2.8 \\
5.4 \\
4.8 \\
7.3 \\
7.5 \\
9.0 \\
9.7 \\
9.1 \\
8.2\end{array}$ & $\begin{array}{l}4.6 \\
3.2 \\
4.2 \\
3.1 \\
5.5 \\
5.5 \\
7.0 \\
7.5 \\
9.2 \\
9.2 \\
9.3 \\
7.7\end{array}$ & $\begin{array}{l}4.6 \\
3.6 \\
4.3 \\
3.2 \\
5.2 \\
3.8 \\
6.5 \\
6.5 \\
8.5 \\
8.4 \\
8.8 \\
7.1\end{array}$ & $\begin{array}{l}4.3 \\
3.8 \\
4.0 \\
4.0 \\
5.4 \\
3.9 \\
6.8 \\
6.2 \\
7.7 \\
6.7 \\
7.7 \\
6.6\end{array}$ & $\begin{array}{l}22.4 \\
16.7 \\
21.6 \\
16.4 \\
26.9 \\
22.9 \\
35.1 \\
35.3 \\
43.8 \\
44.5 \\
44.8 \\
39.4\end{array}$ \\
\hline & mean: & 29.1 & 249 & 6.8 & 6.3 & 6.3 & 5.9 & 5.6 & 30.8 \\
\hline $\begin{array}{l}15: 20 \\
15: 10 \\
17: 10 \\
13: 10 \\
13: 00 \\
17: 20 \\
19: 10 \\
19: 20 \\
23: 20 \\
21: 20 \\
23: 10 \\
21: 10\end{array}$ & $\begin{array}{l}1 \\
1 \\
1 \\
1 \\
1 \\
1 \\
1 \\
1 \\
1 \\
1 \\
1 \\
1\end{array}$ & $\begin{array}{l}23.7 \\
24.4 \\
25.7 \\
26.4 \\
27.0 \\
27.1 \\
28.4 \\
29.7 \\
31.2 \\
32.9 \\
33.6 \\
34.2\end{array}$ & $\begin{array}{l}262 \\
255 \\
256 \\
243 \\
250 \\
252 \\
246 \\
246 \\
252 \\
248 \\
245 \\
249\end{array}$ & $\begin{array}{r}2.6 \\
3.8 \\
4.4 \\
3.2 \\
4.6 \\
3.5 \\
7.3 \\
7.6 \\
10.4 \\
8.4 \\
10.3 \\
10.3\end{array}$ & $\begin{array}{l}3.2 \\
3.7 \\
3.9 \\
3.9 \\
4.4 \\
3.3 \\
7.3 \\
7.5 \\
9.9 \\
8.8 \\
9.5 \\
9.2\end{array}$ & $\begin{array}{l}4.6 \\
4.5 \\
3.5 \\
4.9 \\
5.4 \\
3.6 \\
6.1 \\
7.2 \\
9.9 \\
8.7 \\
9.2 \\
8.5\end{array}$ & $\begin{array}{l}5.2 \\
4.5 \\
3.7 \\
5.1 \\
5.5 \\
5.3 \\
5.9 \\
6.9 \\
9.8 \\
8.0 \\
8.2 \\
7.6\end{array}$ & $\begin{array}{l}5.0 \\
4.5 \\
4.3 \\
5.0 \\
5.7 \\
6.1 \\
6.8 \\
7.1 \\
9.4 \\
7.7 \\
7.8 \\
7.6\end{array}$ & $\begin{array}{l}20.6 \\
21.0 \\
19.8 \\
22.1 \\
25.6 \\
21.8 \\
33.4 \\
36.3 \\
49.4 \\
41.6 \\
45.0 \\
43.2\end{array}$ \\
\hline & mean: & 28.7 & 250 & 6.4 & 6.2 & 6.3 & 6.3 & 6.4 & 31.7 \\
\hline $\begin{array}{l}13: 50 \\
15: 50 \\
17: 40 \\
15: 40 \\
13: 40 \\
17: 50 \\
19: 40 \\
19: 50 \\
23: 50 \\
23: 40 \\
21: 50 \\
21: 40\end{array}$ & $\begin{array}{l}2 \\
2 \\
2 \\
2 \\
2 \\
2 \\
2 \\
2 \\
2 \\
2 \\
2 \\
2\end{array}$ & $\begin{array}{l}24.0 \\
24.0 \\
24.3 \\
24.5 \\
24.7 \\
26.3 \\
29.5 \\
30.9 \\
31.0 \\
31.6 \\
35.1 \\
36.1\end{array}$ & $\begin{array}{l}259 \\
260 \\
246 \\
252 \\
259 \\
253 \\
245 \\
242 \\
245 \\
243 \\
249 \\
252\end{array}$ & $\begin{array}{r}3.6 \\
3.3 \\
5.5 \\
3.3 \\
3.1 \\
5.7 \\
7.5 \\
8.3 \\
10.3 \\
10.1 \\
9.0 \\
8.5\end{array}$ & $\begin{array}{l}4.0 \\
4.0 \\
5.3 \\
3.8 \\
3.8 \\
5.6 \\
7.8 \\
8.0 \\
9.9 \\
9.7 \\
8.7 \\
8.6\end{array}$ & $\begin{array}{r}5.1 \\
5.4 \\
5.1 \\
5.1 \\
4.3 \\
5.8 \\
8.0 \\
7.9 \\
10.1 \\
9.9 \\
7.9 \\
7.9\end{array}$ & $\begin{array}{l}5.0 \\
5.4 \\
5.4 \\
5.8 \\
4.4 \\
5.5 \\
7.8 \\
8.0 \\
9.9 \\
9.7 \\
7.9 \\
7.8\end{array}$ & $\begin{array}{r}4.5 \\
5.0 \\
5.4 \\
5.3 \\
3.9 \\
5.9 \\
7.0 \\
7.9 \\
10.1 \\
9.7 \\
8.8 \\
8.7\end{array}$ & $\begin{array}{l}22.2 \\
23.1 \\
26.7 \\
23.3 \\
19.5 \\
28.5 \\
38.1 \\
40.1 \\
50.3 \\
49.1 \\
42.3 \\
41.5\end{array}$ \\
\hline & mean: & 28.5 & 250 & 6.5 & 6.6 & 6.9 & 6.9 & 6.9 & 33.7 \\
\hline 1 row & $\begin{array}{l}\text { ratios: } \\
2 / 0 \text { rows }\end{array}$ & 98.7 & & 94.3 & 99.2 & 100.1 & 107.4 & 114.8 & 102.7 \\
\hline 2 rows, & 0 rows $\%$ & 98.0 & & 96.5 & 105.3 & 108.6 & 117.2 & 122.5 & 109.4 \\
\hline
\end{tabular}


Table 3-4.e Jess-A Multiple Row Wake Test Analysis (Row 3)

Ten Minute Data Report

FOR WINDFARM: JESS RANCH WINDFARM

\begin{tabular}{|c|c|c|c|c|c|c|c|c|}
\hline $\begin{array}{l}\text { Ten Min } \\
\text { Time } \\
\text { of Day }\end{array}$ & $\begin{array}{l}\text { de Data } \\
\text { rows on } \\
\text { upwind }\end{array}$ & $\begin{array}{l}\text { Report } \\
\text { J08 } \\
\text { ws peed }\end{array}$ & $\begin{array}{r}\text { J08 } \\
\text { w. dir. }\end{array}$ & $\begin{array}{l}09 / 10 / 8 \\
\text { E09 } \\
\text { energy }\end{array}$ & $\begin{array}{l}710 \\
\text { energy }\end{array}$ & $\begin{array}{l}\text { G01 } \\
\text { energy }\end{array}$ & $\begin{array}{l}\text { G03 } \\
\text { energy }\end{array}$ & $\begin{array}{l}\text { sum of } \\
\text { F09-F } 10\end{array}$ \\
\hline \multirow[t]{2}{*}{$\begin{array}{l}15: 20 \\
15: 10 \\
17: 10 \\
13: 10 \\
13: 00 \\
17: 20 \\
19: 10 \\
19: 20 \\
23: 20 \\
21: 20 \\
23: 10 \\
21: 10\end{array}$} & $\begin{array}{l}0 \\
0 \\
0 \\
0 \\
0 \\
0 \\
0 \\
0 \\
0 \\
0 \\
0 \\
0\end{array}$ & $\begin{array}{l}23.7 \\
24.4 \\
25.7 \\
26.4 \\
27.0 \\
27.1 \\
28.4 \\
29.7 \\
31.2 \\
32.9 \\
33.6 \\
34.2\end{array}$ & $\begin{array}{l}262 \\
255 \\
256 \\
243 \\
250 \\
252 \\
246 \\
246 \\
252 \\
248 \\
245 \\
249\end{array}$ & $\begin{array}{r}2.9 \\
4.3 \\
4.8 \\
4.7 \\
4.4 \\
3.4 \\
6.4 \\
8.2 \\
11.7 \\
10.5 \\
11.6 \\
11.9\end{array}$ & $\begin{array}{r}2.8 \\
3.7 \\
4.5 \\
3.5 \\
4.1 \\
3.4 \\
6.9 \\
7.0 \\
11.3 \\
8.2 \\
11.2 \\
11.3\end{array}$ & $\begin{array}{r}2.5 \\
3.1 \\
4.0 \\
2.9 \\
4.3 \\
3.0 \\
7.0 \\
7.1 \\
11.0 \\
8.0 \\
10.7 \\
9.8\end{array}$ & $\begin{array}{r}3.4 \\
3.6 \\
2.8 \\
4.5 \\
4.6 \\
3.0 \\
5.8 \\
7.2 \\
10.9 \\
9.2 \\
9.6 \\
7.9\end{array}$ & $\begin{array}{r}5.7 \\
8.0 \\
9.3 \\
8.2 \\
8.5 \\
6.8 \\
13.3 \\
15.2 \\
23.0 \\
18.7 \\
22.8 \\
23.2\end{array}$ \\
\hline & mean: & 28.7 & 250 & 7.1 & 6.5 & 6.1 & 6.0 & 13.6 \\
\hline \multirow[t]{2}{*}{$\begin{array}{l}15: 50 \\
13: 50 \\
17: 40 \\
15: 40 \\
13: 40 \\
17: 50 \\
19: 40 \\
19: 50 \\
23: 50 \\
23: 40 \\
21: 50 \\
21: 40\end{array}$} & $\begin{array}{l}1 \\
1 \\
1 \\
1 \\
1 \\
1 \\
1 \\
1 \\
1 \\
1 \\
1 \\
1\end{array}$ & $\begin{array}{l}24.0 \\
24.0 \\
24.3 \\
24.5 \\
24.7 \\
26.3 \\
29.5 \\
30.9 \\
31.0 \\
31.6 \\
35.1 \\
36.1\end{array}$ & $\begin{array}{l}260 \\
259 \\
246 \\
252 \\
259 \\
253 \\
245 \\
242 \\
245 \\
243 \\
249 \\
252\end{array}$ & $\begin{array}{r}2.7 \\
2.3 \\
4.3 \\
2.8 \\
3.0 \\
4.4 \\
8.5 \\
8.8 \\
10.6 \\
10.3 \\
8.1 \\
8.7\end{array}$ & $\begin{array}{r}3.1 \\
2.9 \\
4.6 \\
3.2 \\
2.5 \\
4.6 \\
6.8 \\
7.9 \\
10.8 \\
10.3 \\
8.0 \\
7.9\end{array}$ & $\begin{array}{r}2.6 \\
2.9 \\
4.9 \\
2.4 \\
2.8 \\
4.8 \\
7.1 \\
7.7 \\
11.0 \\
10.5 \\
8.9 \\
8.5\end{array}$ & $\begin{array}{r}3.8 \\
3.8 \\
4.7 \\
3.9 \\
3.3 \\
5.3 \\
8.1 \\
8.1 \\
10.9 \\
10.5 \\
8.0 \\
7.9\end{array}$ & $\begin{array}{r}5.8 \\
5.2 \\
8.9 \\
6.0 \\
5.5 \\
9.0 \\
15.3 \\
16.7 \\
21.4 \\
20.6 \\
16.1 \\
16.6\end{array}$ \\
\hline & mean: & 28.5 & 250 & 6.2 & 6.1 & 6.2 & 6.5 & 12.3 \\
\hline ratio & $(1 / 0 \%)$ & 99.3 & & 87.9 & 93.2 & 101.0 & 108.0 & 90.4 \\
\hline
\end{tabular}


The Jess-A study array is aligned for winds from a direction of about $230^{\circ}$. However, the winds at J08 were more westerly, from $250^{\circ}$. Apparently the wake deficits passed to the south of the array. Evidence for this is that the turbines at the south end of each string experienced more wake deficits than those at the north end. In addition, many of the 10-min mean wind speeds were above $30 \mathrm{mph}$. The $16 \mathrm{D}$ test data suggested that wake deficits from the more distant upwind rows would be negligible in winds of this magnitude. Thus there were problems with both the wind direction and speed that masked the deficits from the more distant rows.

Statistical analysis of these deficits shows decreasing levels of significance as more rows are switched on. With one row on, the significance level of the energy deficit was 0.95 , but this decreased to 0.90 for two rows on, and to 0.70 for three upwind rows on.

Table 3-4.d is the analysis of the second row (from the back). There are two upwind rows and the data is sorted into three groups, no upwind rows on, one row on and two rows on. The curious pattern seen in the back row was evident here as well. The mean energy in this row increased as one, and then two upwind rows were switched on line. Only the southern end of the row, at turbine K3, showed an energy decrease, and the other four turbines all showed energy increases. Perhaps decreases would have been measured at turbines K1 and $\mathrm{K} 2$, but these buffer turbines were switched off for the entire test. The deficit at turbine $\mathrm{K} 3$ was only significant at the 0.60 level.

Table 3-4.e is the analysis of the next upwind row, and it is essentially the same as a direct wake test. Turbines F9 and F10 at the south end of the row showed a decrease in energy when the upwind row was switched on. However, turbines G1 and G3 showed energy increases. (Turbine G2 was faulted for most of the test, so the data is not included in the analysis). The deficit at turbine $F 9$ had a significance level of only 0.70 .

Thus, we see that in all three test rows, the southern ends of the rows had some energy decreases while the northern ends of the rows had increases. Based on the wind direction data at J08, and the observed pattern of energy decreases in each row, the test array was poorly aligned with the wake trajectory during this test.

\subsubsection{Test 3 Analysis, Souza-C, October 9, 1987}

Tables 3-4.f and 3-4.g are the data listings for the October 9 test on Souza. Because of the way the upwind rows were cycled on and off, there are only half as many observations in the mode with no upwind rows on. It does not appear to have affected the data, although the smaller sample size affects the statistical significance calculation. The results from this test are somewhat similar to those from the September 4 test. Table 3-4.f shows that the winds at $\mathrm{S} 13$ were about $23 \mathrm{mph}$ from the southwest. The table also shows that winds at $S 27$ were about $21 \mathrm{mph}$. In this test, energy production at the test turbines was found to be better correlated to $\$ 27$ speeds than to $\$ 13$ speeds, so S27 was used as the reference anemometer. As in several previous tests, there was a difference in mean speeds between test periods, so a second set of means was calculated for the second and third periods. The "norma1 ized" data sets have mean speeds of $20.6 \mathrm{mph}$ and $20.8 \mathrm{mph}$, which are very close to those of the first period. Two sets of ratios were calculated: one 
Pable 3-4.f Souza-C tultiple Ron Hake test Analysis

Fen Vinute Data Report

POR MIIDRARH: SOOZL RAICH MINDPABH

$10 / 09 / 87$

Tive rous on $\$ 13 \quad 513 \quad 527 \quad$ B10 $\quad$ \$11 $\quad$ B12 $\quad$ B13 $\quad$ B14 sun of Of Day uprind aspeed R.dir. nspeed energy energy energy energy energy B10-B14

\begin{tabular}{|c|c|c|c|c|c|c|c|c|c|c|c|c|c|}
\hline & & & & & & & & & & & & & \\
\hline $17: 10$ & 0 & 23 & 245 & 16.8 & 5.9 & 5.1 & 1.8 & 4.5 & 3.6 & 23.9 & 19.6 & 16.7 & 16.3 \\
\hline $17: 50$ & 0 & 22.9 & 245 & 18.1 & 6.3 & 5.1 & 5.8 & 5.5 & 4.5 & 27.5 & 19.9 & 18.2 & 17.4 \\
\hline $22: 30$ & 0 & 25.5 & 232 & 19.7 & 6.7 & 5.8 & 6.5 & 7.1 & 7.2 & 33.4 & 21.4 & 20.9 & 22.6 \\
\hline $20: 00$ & 0 & 26.1 & 235 & 20.1 & 7.1 & 6.6 & 1.2 & 7.4 & 6.7 & 35 & 22.2 & 21.1 & 21.5 \\
\hline $15: 30$ & 0 & 21.3 & 217 & 20.3 & 6.4 & 5.8 & 6.2 & 6.4 & 6.4 & 31.2 & 21.1 & 19.6 & 20.8 \\
\hline $20: 10$ & 0 & 26.9 & 235 & 20.6 & 7.9 & $?$ & 1.3 & 7.3 & 6.7 & 36.2 & 23.3 & 21.7 & 21.4 \\
\hline $15: 20$ & 0 & 22 & 231 & 21.3 & 7.1 & 6.5 & 6.6 & 6.7 & 6.1 & 33.3 & 22.7 & 20.7 & 20.6 \\
\hline $22: 20$ & 0 & 26.1 & 218 & 21.6 & 7 & 6 & 5.7 & 5.9 & 6 & 30.6 & 22.1 & 19.9 & 20.4 \\
\hline $10: 10$ & 0 & 21.7 & 233 & 21.6 & 7.7 & 6.8 & 7.1 & 7.4 & 7 & 36 & 23.1 & 21.6 & 22 \\
\hline $13: 10$ & 0 & 22.1 & 214 & 22.1 & 6.9 & 5.1 & 6.2 & 6.6 & 6 & 30.8 & 22.6 & 20.7 & 20.3 \\
\hline $10: 50$ & 0 & 24.7 & 233 & 23.2 & 8.5 & 7.6 & 8 & 7.7 & 7.1 & 38.9 & 25 & 23.9 & 22.7 \\
\hline $13: 00$ & 0 & 22.3 & 219 & 23.4 & 7.9 & 6.5 & 6.8 & 6.7 & 5.6 & 33.5 & 23.9 & 21.2 & 20.1 \\
\hline Hean: & & 24.0 & 230 & 20.7 & 7.1 & 6.2 & 6.5 & 6.6 & 6.1 & 32.5 & 22.3 & 20.5 & 20.5 \\
\hline $18: 10$ & 1 & 21.7 & 231 & 14.9 & 2.9 & 2.3 & 2.2 & 2.6 & 2.2 & 12.2 & 15.6 & 11.1 & 14.7 \\
\hline $17: 10$ & 1 & 20.1 & 242 & 16.5 & 4.8 & 4 & 3.8 & 3.8 & 3.2 & 19.6 & 18.8 & 16.7 & 16.3 \\
\hline $16: 00$ & 1 & 18.8 & 245 & 16.9 & 3.7 & 3.3 & 3.1 & 3.4 & 2.7 & 16.2 & 17 & 15 & 15 \\
\hline $18: 20$ & 1 & 21.8 & 239 & 18.1 & 4.5 & 2.8 & 2.5 & 2.2 & 1.6 & 13.6 & 18.4 & 14.7 & 13.5 \\
\hline $17: 20$ & 1 & 23.2 & 239 & 18.1 & 4.6 & 3.6 & 3.1 & 3.1 & 2.1 & 16.8 & 18.8 & 16.3 & 15.1 \\
\hline $20: 30$ & 1 & 26.5 & 229 & 19.5 & 7.4 & 6.1 & 6.5 & 1 & 6.8 & 34.1 & 23.2 & 21.4 & 22.4 \\
\hline $19: 40$ & 1 & 26.3 & 231 & 19.7 & 6.7 & 6 & 6 & 6.1 & 6.2 & 31.3 & 22.4 & 20.1 & 21.1 \\
\hline $15: 50$ & 1 & 20.2 & 248 & 19.7 & 5.2 & 4.2 & 4.3 & 4.4 & 3.6 & 21.7 & 19.6 & 17.1 & 16.3 \\
\hline $14: 50$ & 1 & 21.8 & 231 & 19.9 & 6.2 & 4.8 & 5 & 5.5 & 1.8 & 26.3 & 21.2 & 19 & 18.9 \\
\hline $20: 40$ & 1 & 26.1 & 232 & 19.9 & 6.3 & 5.8 & 5.9 & 6.5 & 6.3 & 30.8 & 21.9 & 20.6 & 21.1 \\
\hline $19: 30$ & 1 & 27 & 242 & 19.9 & 6.7 & 6.2 & 6.2 & 6.8 & 5.6 & 31.5 & 22.2 & 20.6 & 20.1 \\
\hline $12: 30$ & 1 & 22.7 & 233 & 20.2 & 6.8 & 5.5 & 5.8 & e 5.8 & 5.2 & 29.1 & 22.1 & 20.8 & 16.6 \\
\hline $13: 30$ & 1 & 21.2 & 214 & 20.7 & 6.4 & e 4.5 & 4.7 & 4.8 & 4.1 & 24.8 & 21.2 & 18.7 & 18.5 \\
\hline $12: 40$ & 1 & 21.2 & 231 & 20.7 & 6.5 & 5.3 & 5.1 & 5.5 & 5.2 & 27.6 & 22.4 & 20.2 & 19.8 \\
\hline $15: 00$ & 1 & 21.6 & 231 & 20.1 & 6 & 4.9 & 4.7 & 4.8 & 4.5 & 24.9 & 21.3 & 18.9 & 18.2 \\
\hline $13: 40$ & 1 & 20.1 & 236 & 21.1 & 6.6 & e 5.2 & 5.4 & 5.7 & 4.9 & 27.8 & 21.7 & 19.7 & 19.1 \\
\hline $22: 00$ & 1 & 21.8 & 221 & 21.8 & 9.1 & 7.6 & 7.7 & 7.1 & 6.2 & 37.7 & 26.7 & 24.6 & 22.1 \\
\hline $22: 50$ & 1 & 27 & 221 & 22.5 & 7.5 & 5.8 & 5.6 & 5.8 & 5.8 & 30.5 & 22.8 & 20.6 & 21.1 \\
\hline $23: 00$ & 1 & 26.1 & 229 & 23.3 & 7 & 5.2 & 5.2 & 5.5 & 5.6 & 28.5 & 22.1 & 19.6 & 20.3 \\
\hline $11: 20$ & 1 & 25.3 & 211 & 24.1 & 9 & 7.1 & 7.6 & 7.5 & 7 & 38.5 & 26.6 & 23.9 & 23.1 \\
\hline $11: 10$ & 1 & 23.5 & 211 & 24.3 & 8.8 & 1.1 & 7.1 & 7.2 & 7 & 37.8 & 26.1 & 23.8 & 23.3 \\
\hline $21: 50$ & 1 & 23.6 & 218 & 25.2 & 9 & 7.2 & 7.4 & 7 & 6.6 & 37.2 & 26 & 24.3 & 22.6 \\
\hline Hean: & & 23.1 & 230 & 20.4 & 6.1 & 5.2 & 5.3 & 5.4 & 1.9 & 27.2 & 21.7 & 19.6 & 19.2 \\
\hline Morn. Hean: & & 23.2 & 230 & 20.6 & 6.6 & 5.4 & 5.4 & 5.5 & 5.0 & 27.9 & 22.0 & 19.9 & 19.1 \\
\hline
\end{tabular}

Note: $e=$ estinate due to turbine not operating full 10-ninutes 
fable 3-4.f Souza-C Hultiple Bon Make fest Inalysis

live rops on $\$ 13 \quad$ \$13 $\$ 29 \quad 810 \quad 811 \quad 812 \quad 813 \quad 814$ sun of of Day uprind "sspeed n.dir. uspeed energy energy energy energy energy 810-811

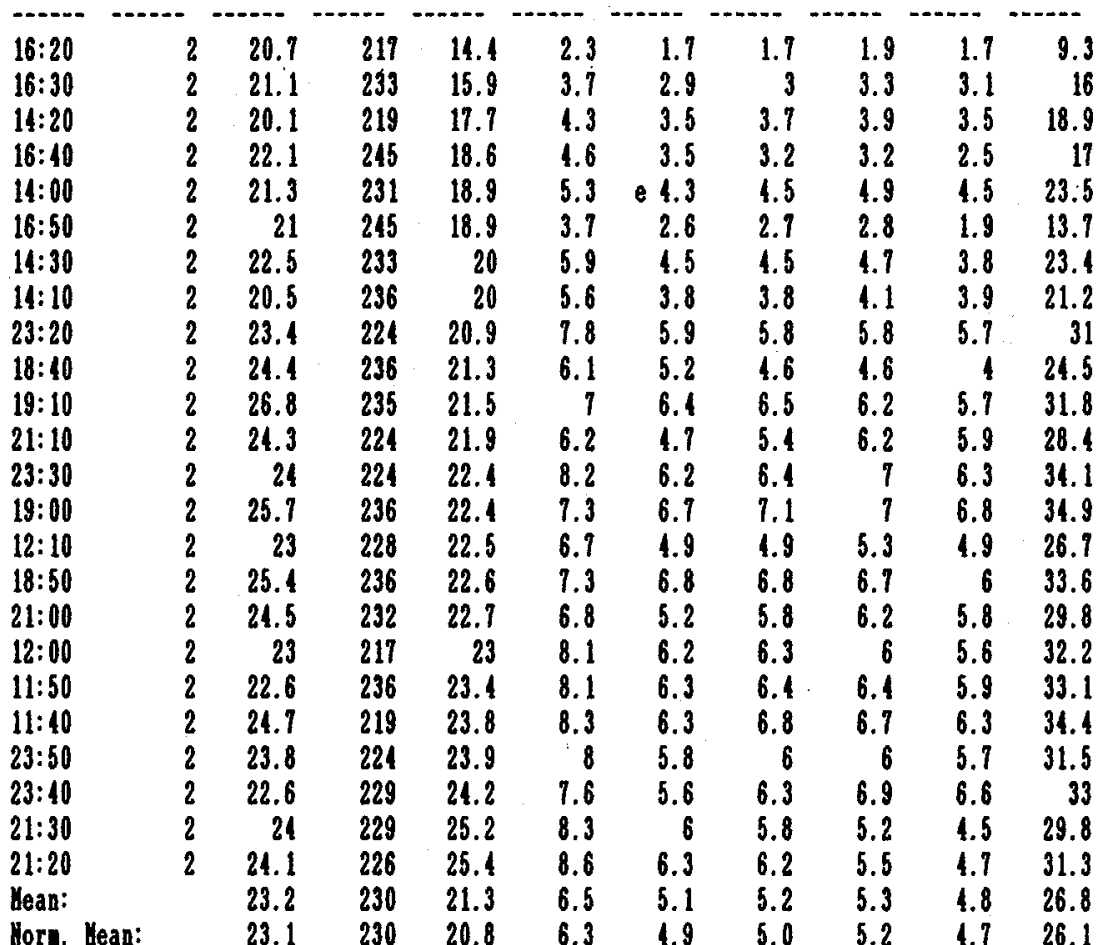

Ratios, using all available data:

2 rons on/none 96.4

$\begin{array}{lllllll}98.3 & 90.2 & 84.7 & 80.6 & 81.5 & 80.4 & 83.6\end{array}$

102.8

$90.9 \quad 81.6 \quad 79.4$

79.9

79.1

82.1

Horalized ratios:

1 ron on/none on

2 rous on/none

96.4

99.5

$92.5 \quad 87.0$

$\begin{array}{llll}82.8 & 83.5 & 82.5 & 85.8\end{array}$

100.

87.5

79.5

77.4

78.6

$78.0 \quad 80.1$

2 rons on $/ 1$ on 99.7

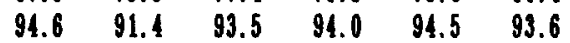

$810 \quad 812 \quad \$ 14$ nspeed rispeed nspeed

$15.3 \quad 13.2 \quad 14.1$

$17.1 \quad 15.9 \quad 15.9$

$18.1 \quad 16.6 \quad 16.8$

$\begin{array}{lll}18.8 & 16.1 & 15.1\end{array}$

$19.8 \quad 18.1 \quad 18.5$

$16.7 \quad 14.6 \quad 13.7$

$20.7 \quad 18.1 \quad 17.6$

$20.2 \quad 17.1 \quad 17.2$

$23.2 \quad 20.5 \quad 20.6$

$21.3 \quad 18.2 \quad 17.9$

$23.1 \quad 20.9 \quad 20.7$

$21.3 \quad 20.5 \quad 20.9$

$24.6 \quad 21.9 \quad 22.2$

$\begin{array}{lll}23.6 & 22.7 \quad 21.8\end{array}$

$22.1 \quad 19.1 \quad 19.1$

$24.1 \quad 22 \quad 21.5$

$21.8 \quad 20.5 \quad 20.6$

$21.1 \quad 21.6 \quad 20.6$

$24.6 \quad 21.4 \quad 21.3$

$24.9 \quad 22.1 \quad 21.6$

$23.9 \quad 21.3 \quad 21.1$

$23.2 \quad 21.4 \quad 22.2$

$24.7 \quad 20.9 \quad 19.3$

$25.6 \quad 21.5 \quad 19.6$

$21.8 \quad 19.5 \quad 19.2$

$21.1 \quad 19.2 \quad 19.0$

Turbine anemoneter data:

Speed ratios (nornalized period)

1 ron on/none on

2 rons on/none

$\begin{array}{lllll}98.9 & \mathrm{H} / \mathrm{L} \quad 96.8 \quad \mathrm{~N} / \mathrm{L} \quad 94.8\end{array}$

$\begin{array}{lll}96.1 & 93.6 & 92.7\end{array}$

Poner ratios (anes. data, norn. period)

1 ron on/none on

2 rons on/none
$99.4 \quad 1 / 4 \quad 93.9 \quad$ N/4 88.4

page 2 of 2 
Iable 3-4.g Souza-C Vultiple Ror hake lest - Middle Don Analysis

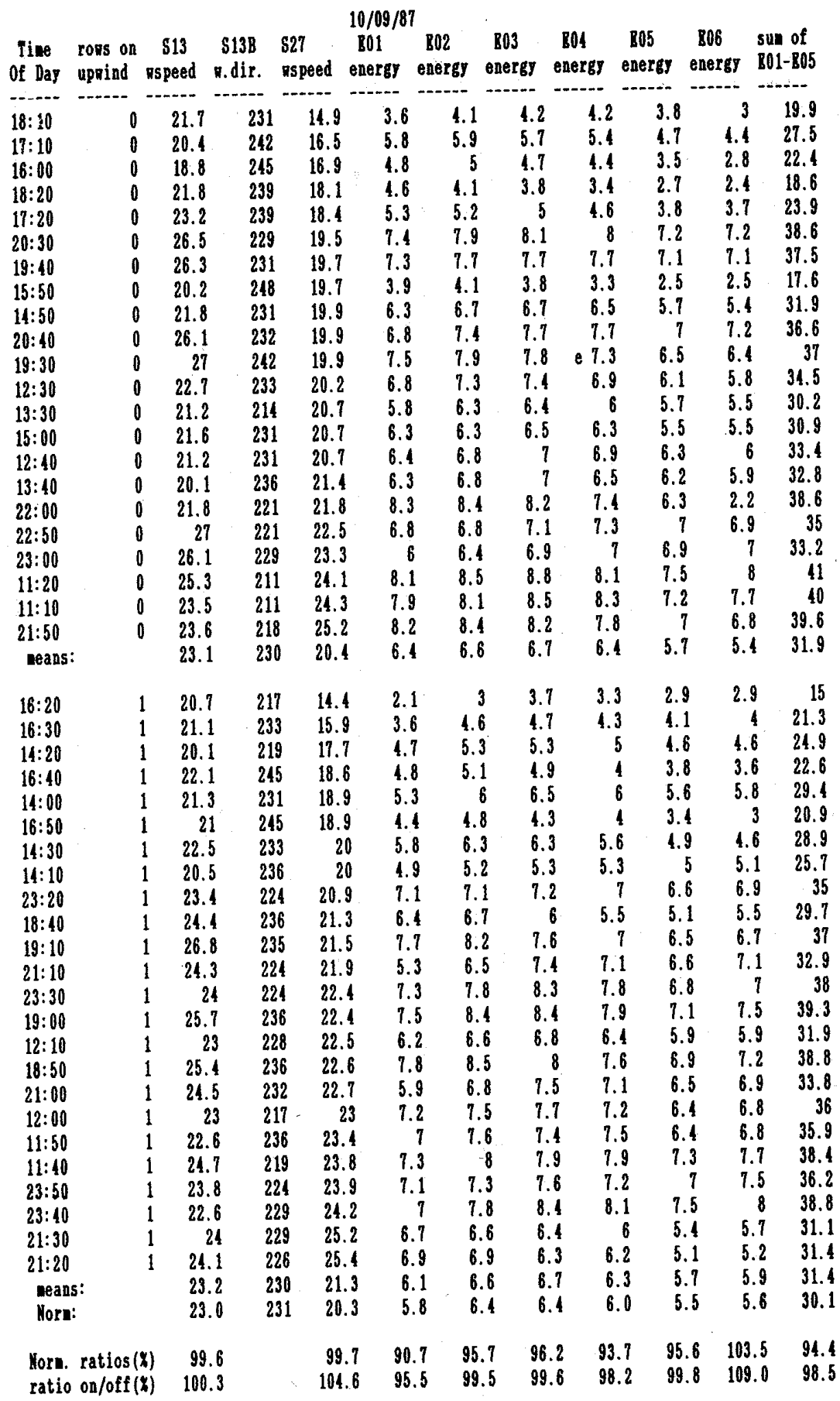


for the entire data set and one for the adjusted data set. The analysis will focus on the latter because the bias in wind speeds at 527 is smaller.

The mean energy ratio of the five turbines, E10 - E14, shows that a large drop occurred when the first set of upwind turbines was switched on. Table 3-4.f shows that the ratio was $85.8 \%$, which is equivalent to an energy deficit of $14.2 \%$. The lowest ratios, or highest deficits, were at E12 through E14, and the smallest deficits were at E10 and E11. This pattern was probably due to a combination of terrain effects and wake trajectory. It is likely that turbine El0 was at the wake boundary because this array is aligned with $240^{\circ}$ and the wind direction was $230^{\circ}$.

When the second set of upwind turbines was switched on, there was an additional $5.4 \%$ deficit, which is $38 \%$ of the initial $14.2 \%$ drop. Turbine Ell experienced the largest incremental deficit -- 7.5\%. The other turbines in this row had deficits of about $5 \%$.

Wind speed data from three turbine anemometers installed at $35 \mathrm{ft}$ agl were analyzed and wind power density $\left(\mathrm{W} / \mathrm{m}^{2}\right)$ was calculated for the individual 10-min wind speeds. The wind power density deficits were not as large as the energy deficits at two of the three turbines, E10 and E12. However, at E14 the power density deficits were almost as large as the energy deficits.

Statistical significance of the energy deficits for one and two rows on was 0.95 and 0.99 , respectively. However, the statistical significance for the incremental deficit of two rows on versus one row on was only 0.75 . The level of significance for turbine Ell was a bit higher at 0.80 for the incremental wake.

The individual turbine deficits are plotted in Figure 3-4.b. This is a topographic map with the deficits plotted at each turbine, parallel to the wind direction. The deficits from the first row of turbines are plotted as solid black bars. The deficits from the second row are plotted as open rectangles extending from the solid bars.

Table $3-4 . \mathrm{g}$ is the middle row analysis and is basically the same as a direct wake test. It should be noted that turbine $\mathrm{F} 4$, in the middle of the upwind row, was nonoperational throughout this test. This gap in the upwind row could have affected the wake deficits in this test row. Spacing between these rows is $10.2 \mathrm{D}$. S27 was also used as the reference anemometer in this test. Because there was a $0.9 \mathrm{mph}$ difference between periods, a second set of means was calculated for the second period. Table 3-4.g shows that the mean speeds were within $0.1 \mathrm{mph}$ for the normalized period, indicating little bias. The energy ratio between the two periods shows that the mean deficit at turbines E1 through E5 was $5.6 \%$. The largest deficit was at turbine E1-- $9.3 \%$. Turbine E6 actually had a $3.5 \%$ increase in energy when the upwind row was turned on. It would appear that the increased distance between rows, as well as the nonoperational status of turbine $F 4$ in the middle of the upwind row, reduced the deficits at this row. Because of the small magnitude of the energy deficits, the speed deficits were not calculated in this case. The statistical significance of the individual deficit at turbine El was 0.90 and 0.80 for the mean row deficit. 


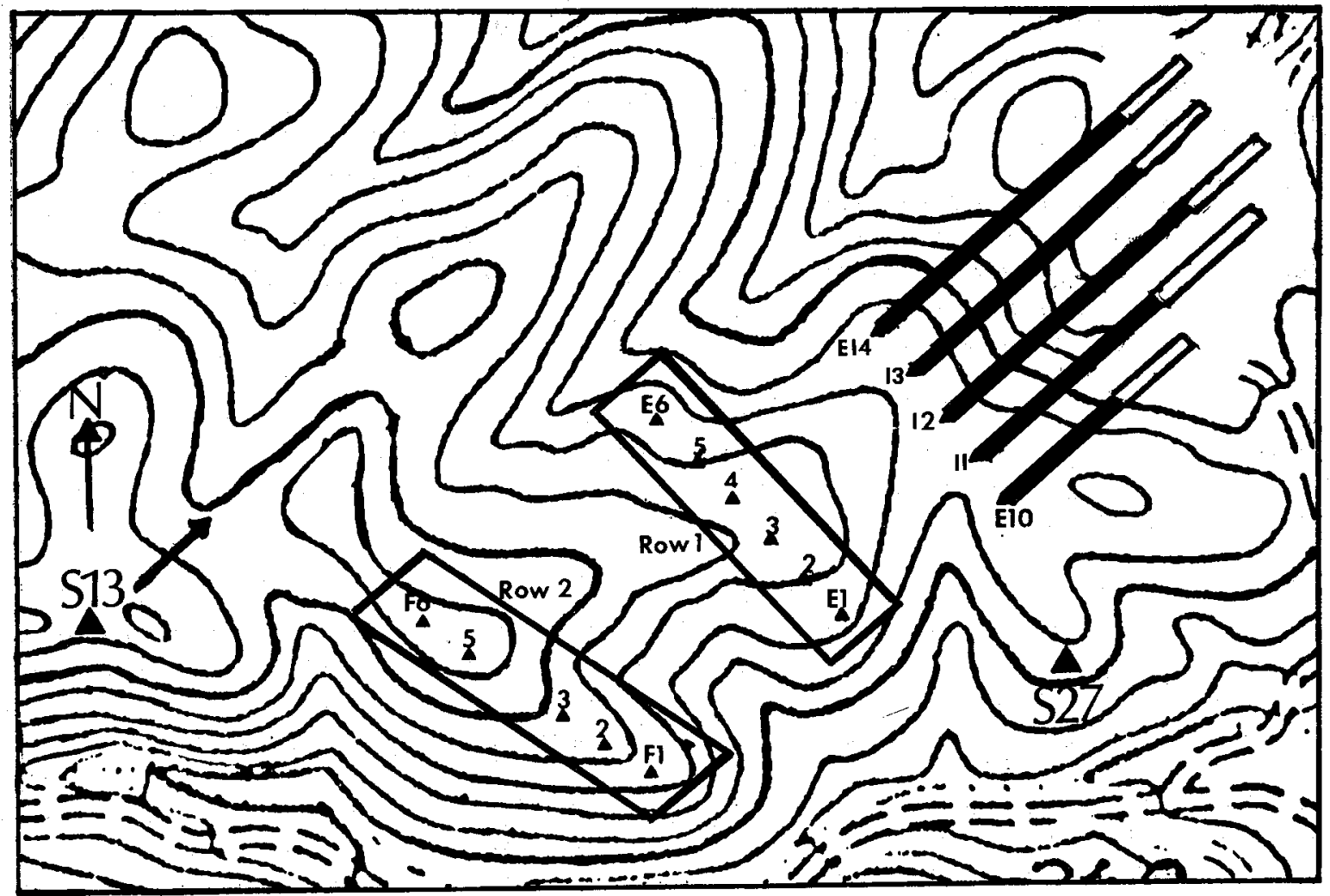

Figure 3-4. b. Souza-C Multiple Row Wake Test Individual Turbine Deficits

Oct 9, 1987 test conditions at reference anemometers;

S-13: mean speed $=23.2 \mathrm{mph}$, mean direction $=230$ degrees, $\mathrm{S}-27$ : mean speed $=20.6 \mathrm{mph}$.

KEY

$\begin{aligned} \Delta \Delta \Delta \Delta & =\text { turbine rows switched on and off } \\ & =\% \text { wake energy deficit, } 1 \text { row on }, 1^{\prime \prime}=10 \% \\ & =\% \text { wake energy deficit, } 2 \text { rows on, } 1^{\prime \prime}=10 \%\end{aligned}$

Deficits

$\begin{array}{rcc}\text { Turbine } & 1 \text { row on } & 2 \text { rows } \\ \text { E10 } & 7.5 \% & 12.5 \% \\ \text { E11 } & 13.0 \% & 20.5 \% \\ \text { E12 } & 17.2 \% & 22.6 \% \\ \text { E13 } & 16.5 \% & 21.4 \% \\ \text { E14 } & 17.5 \% & 22.0 \% \\ \text { Mean } & 14.2 \% & 19.6 \%\end{array}$




\subsubsection{Summary}

The results of the three Multiple Row Wake Tests are consistent with the previous findings. There was a significant energy deficit when the first upwind row was switched on. In Test 1 , there was a $4.5 \%$ energy deficit. In Test 2 there was almost a $17 \%$ deficit, and in Test 3 , the deficit was about $14 \%$. The smaller deficit in Test 1 may have been due to the higher winds, which were about $30 \mathrm{mph}$. In Test 2 and 3 , the winds were lower than in Test 1.

Thus, we see that in all three tests, there was a significant energy deficit when one row of upwind turbines was switched on. The magnitude of the deficit was consistent with the direct wake test results. When the second row of upwind turbines was switched on, there was an additional deficit. In Test 1 , there was an incremental deficit of about $1 \%$ at the test turbines. Recall that the winds at J08 were close to $30 \mathrm{mph}$. When the analysis was restricted to winds below $30 \mathrm{mph}$, the incremental deficit was $3 \%$. This $3 \%$ deficit was close to $50 \%$ of the single row deficit of $6.5 \%$. In Test 2 , there was no incremental deficit, but the wind direction during this test was $20^{\circ}$ off axis of the test array. The wake deficits apparently missed the test turbines. In addition, many of the 10-min mean speeds were above $30 \mathrm{mph}$, which is apparently too high to measure the more distant row wake deficits. In Test 3 , the incremental energy deficit from the second row was $5.4 \%$. This deficit is close to $40 \%$ of the single row deficit of $14.2 \%$. In this test, the distance to the second upwind row is $250 \%$ of the distance to the first upwind row -$17 \mathrm{D}$, versus $6.8 \mathrm{D}$. In addition, turbine $\mathrm{F} 4$, in the middle of the second upwind row, was not operational. Thus, we see that in the two tests that had proper wind directions for the study groups, the incremental deficits were $50 \%$ and $40 \%$ of the first row deficit. The $40 \%$ deficit might have been closer to $50 \%$ if the second upwind row were fully operational and the upwind spacing to this row were $200 \%$ instead of $250 \%$.

These results are consistent with the blockbuster and the $16 \mathrm{D}$ tests conducted at Jess-C. The 16 D test data suggested that wake deficits from the more distant rows would be negligible above $31 \mathrm{mph}$. In these three Multiple Row Tests, the incremental deficit was negligible in the higher winds, but quite apparent in the tests with lower winds. The Jess blockbuster ( 2 row) deficits were much higher than any of the single row (direct wake) deficits, and that test was conducted in fairly low winds (17-18 $\mathrm{mph})$.

To illustrate the inverse relationship between wind speed and wake deficits, the mean two-row deficits have been plotted as a function of wind speed. Figure 3-4.c is a plot of the two-row deficits, and uses data from the Multiple Row Wake Tests and the blockbuster tests. The regression lines have been plotted for the two-row data (heavier line), and for comparison purposes, from the one-row data (direct wake tests). The regression analysis shows that the slope of the two-row deficit line is roughly twice as steep as that of the one-row line. Thus, a given change in wind speed would produce twice as large a change in wake deficits. The correlation coefficient between the energy deficits and wind speed was excellent at -0.96 . Although not plotted, the correlation coefficient between the energy deficits and two turbine performance parameters were also calculated. The correlation was 0.97 to the thrust coefficient and 0.93 to the coefficient of power. 


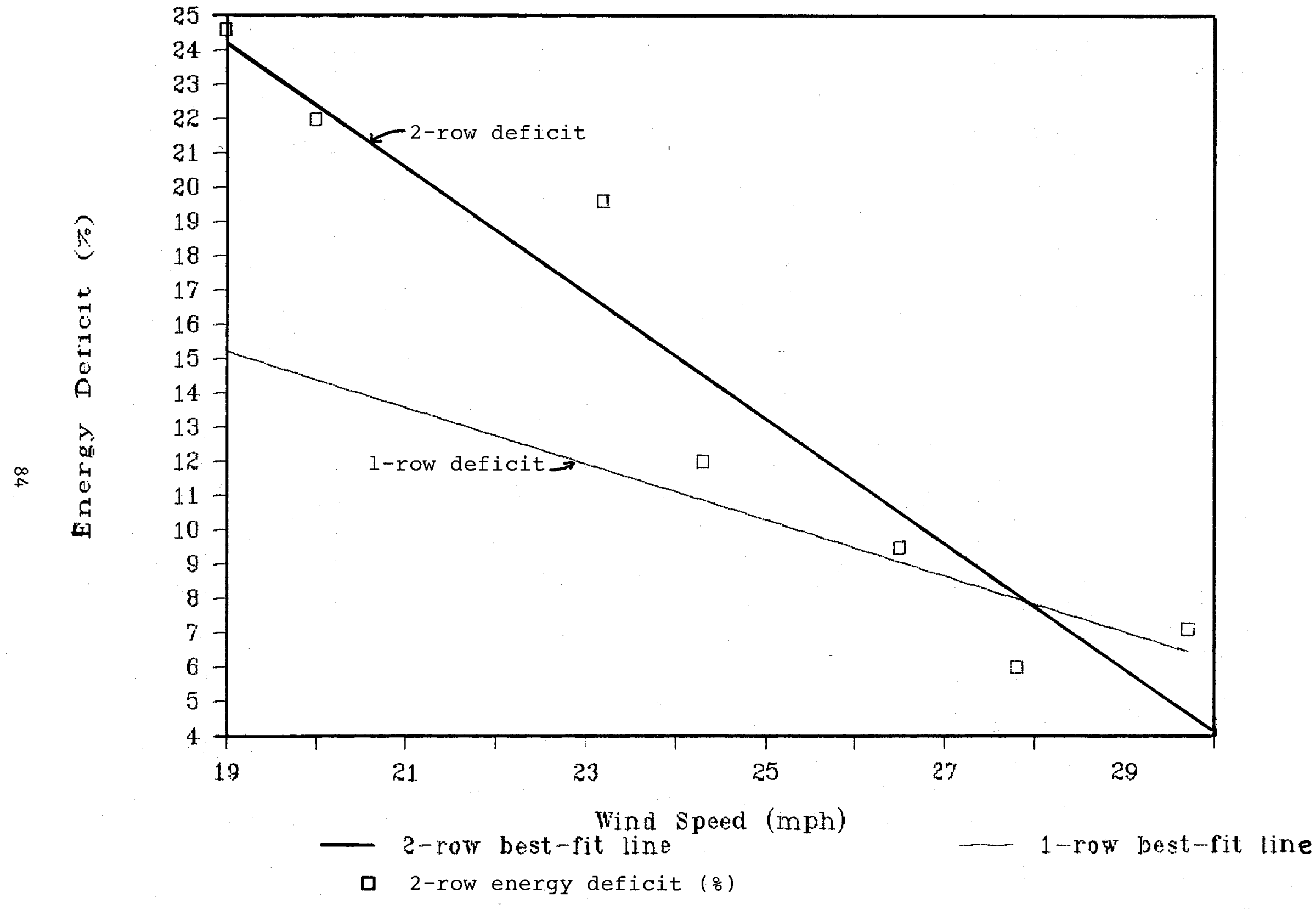

Figure 3-4.c. 2-Row Wake Deficits ( $(x)$ vs. Wind speed (mph) 
A curious phenomenon seen in a few instances was an energy increase at one end of a row and an energy deficit at the other end. The magnitude of the energy increases was 1 arger than the deficits (see Tables 3.4.d and 3.4.e). The area where these increases occurred was outside the expected wake trajectory, so one might expect 1ittle change in energy at these sites. A possible explanation for the energy increase is the "windwall" effect. Perhaps when an entire row of turbines is switched on, there is divergence around the row. This could cause an energy increase at the sites that are not directly downwind of the row that was switched on line.

\subsection{Lateral Induction Test, Jess-C, September 10, 1987}

The Lateral Induction Test was designed to measure the effects on an individual turbine when the turbines immediately adjacent to it are switched on and off. The test plan was to turn on and off every other turbine in a given row. The other turbines (test turbines) in the row remain on throughout the test. The energy production from the test turbines was sorted into two periods -- when the adjacent turbines were on, and when they were off. If lateral induction effects were present, the test turbines' performance should increase when all the turbines are switched on.

The Lateral Induction Test was conducted on September 10, 1987, from 14:40 PDT to 18:40 PDT on the Jess-C group turbines (see Figure 2-1). Turbines L1 through L5 were used in the test -- L1, L3, and L5 were turned on and off every $20 \mathrm{~min}$, and $\mathrm{L} 2$ and $\mathrm{L4}$, which are embedded in this group, were the test turbines. Turbine L6 was left on during the test, but the data were not analyzed because $L 6$ is at the end of the row.

The data records and analysis for this test can be found in Table 3-5.a. The table shows that the winds were from the west-southwest and the mean speeds for the two test periods were $25.0 \mathrm{mph}$ and $24.9 \mathrm{mph}$, almost exactly equal. The ratios of energy (calculated by dividing the period with adjacent turbines on by the period with them off) were $97.2 \%$ at turbine L2, $99.8 \%$ at L4, and $98.5 \%$ for the average of the two. Thus, there was almost no difference between the two periods and no statistically significant lateral induction effects were measured in this test. Perhaps closer crosswind spacing is needed to see these effects.

Although the test was not designed for the following purpose, the energy production at the next row downwind was also examined. In essence, this is an analysis of the wake effects of turning on/off a half-row of turbines, or changing the lateral spacing of the upwind row from 3.8 to $1.9 \mathrm{D}$. Because this was designed as a lateral induction test, there were no 10-min transition periods between test configuration changes as there would have been for other kinds of tests. These periods allow wakes to reach or leave the downwind test rows, and data during these periods are not included in the test analysis. However, in wind speeds of $25 \mathrm{mph}$, with the spacing on the Jess Ranch, the wakes would only take $11 \mathrm{~s}$ to reach the next row. Thus, the lack of transition periods should have negligible effects on the data analysis.

Table 3-5.b 1ists the data for turbines L8 through L13. (Turbine L12 was not communicating properly during this test, and the data are not included here). In this analysis, the energy ratios between the two periods show that 
Table 3-5.a Lateral Induction Test

\begin{tabular}{|c|c|c|c|c|c|c|}
\hline $\begin{array}{l}\text { Time } \\
\text { of Day }\end{array}$ & $\begin{array}{l}\text { turbines } \\
\text { on: }\end{array}$ & $\begin{array}{l}5 \text { J08 } \\
\text { ws peed }\end{array}$ & $\begin{array}{c}\text { J08 } \\
\text { พ. dir. }\end{array}$ & $\begin{array}{l}\text { L02 } \\
\text { energy }\end{array}$ & $\begin{array}{l}\text { L04 } \\
\text { energy }\end{array}$ & $\begin{array}{l}\text { Sum of } \\
\mathrm{L} 2+\mathrm{L} 4\end{array}$ \\
\hline $\begin{array}{l}16: 30 \\
16: 20 \\
15: 00 \\
17: 00 \\
15: 50 \\
17: 40 \\
15: 10 \\
15: 40 \\
17: 10 \\
17: 50 \\
18: 20 \\
18: 30 \\
\text { Mean: }\end{array}$ & $\begin{array}{l}3 \\
3 \\
3 \\
3 \\
3 \\
3 \\
3 \\
3 \\
3 \\
3 \\
3 \\
3\end{array}$ & $\begin{array}{l}22.6 \\
22.9 \\
23.5 \\
23.6 \\
24.0 \\
24.3 \\
24.4 \\
24.5 \\
25.7 \\
26.3 \\
28.7 \\
29.4 \\
25.0\end{array}$ & $\begin{array}{l}246 \\
248 \\
235 \\
248 \\
260 \\
246 \\
255 \\
252 \\
256 \\
253 \\
252 \\
246 \\
250\end{array}$ & $\begin{array}{r}6.4 \\
6.7 \\
6.9 \\
7.3 \\
7 \\
7.4 \\
6.8 \\
7.3 \\
7.5 \\
8 \\
9 \\
9.7 \\
7.5\end{array}$ & $\begin{array}{r}6.4 \\
6.4 \\
6.9 \\
7 \\
7 \\
7.1 \\
7.5 \\
7.4 \\
7.7 \\
8 \\
9.1 \\
9.3 \\
7.5\end{array}$ & $\begin{array}{r}12.8 \\
13.1 \\
13.8 \\
14.3 \\
14 \\
14.5 \\
14.3 \\
14.7 \\
15.2 \\
16 \\
18.1 \\
19 \\
15.0\end{array}$ \\
\hline $\begin{array}{l}14: 40 \\
16: 10 \\
14: 50 \\
16: 00 \\
15: 20 \\
15: 30 \\
16: 50 \\
16: 40 \\
17: 20 \\
17: 30 \\
18: 10 \\
18: 00 \\
\text { Mean: }\end{array}$ & $\begin{array}{l}6 \\
6 \\
6 \\
6 \\
6 \\
6 \\
6 \\
6 \\
6 \\
6 \\
6 \\
6\end{array}$ & $\begin{array}{l}21.8 \\
22.9 \\
23.1 \\
23.2 \\
23.7 \\
24.1 \\
24.4 \\
25.1 \\
27.1 \\
27.3 \\
27.6 \\
28.6 \\
24.9\end{array}$ & $\begin{array}{l}259 \\
259 \\
255 \\
252 \\
262 \\
253 \\
252 \\
252 \\
252 \\
252 \\
249 \\
250 \\
254\end{array}$ & $\begin{array}{l}6.1 \\
6.3 \\
6.4 \\
6.9 \\
7 \\
7.2 \\
6.9 \\
7.2 \\
8.2 \\
8.3 \\
8.4 \\
8.6 \\
7.3\end{array}$ & $\begin{array}{l}5.9 \\
6.7 \\
6.7 \\
6.5 \\
6.8 \\
7.3 \\
7.3 \\
7.7 \\
8.2 \\
8.4 \\
8.8 \\
9.3 \\
7.5\end{array}$ & $\begin{array}{r}12 \\
13 \\
13.1 \\
13.4 \\
13.8 \\
14.5 \\
14.2 \\
14.9 \\
16.4 \\
16.7 \\
17.2 \\
17.9 \\
14.8\end{array}$ \\
\hline $\begin{array}{l}\text { Ratio ol } \\
\text { Inverse }\end{array}$ & $\begin{array}{l}\text { /off }(\%) \\
\text { ratio }\end{array}$ & $\begin{array}{r}99.7 \\
100.3\end{array}$ & & $\begin{array}{r}97.2 \\
102.9\end{array}$ & $\begin{array}{r}99.8 \\
100.2\end{array}$ & $\begin{array}{r}98.5 \\
101.5\end{array}$ \\
\hline
\end{tabular}


Table 3-5.b Effect of 1/2 row of turbines

(changing lateral spacing at upwind row from 3.8 to $1.9 \mathrm{RD}$ )

Ten Minute Data Report

FOR WINDFARM: JESS RANCH WINDFARM

\begin{tabular}{|c|c|c|c|c|c|c|c|c|c|}
\hline $\begin{array}{l}\text { REPORT } \\
\text { Time } \\
\text { Of Day }\end{array}$ & $\begin{array}{l}\text { rows on } \\
\text { upwind }\end{array}$ & $\begin{array}{c}\text { J08 } \\
\text { wspeed }\end{array}$ & $\begin{array}{l}\text { J08 } \\
\text { พ. dir. }\end{array}$ & $\begin{array}{l}09 / 10 / 8 \\
\text { L08 } \\
\text { energy }\end{array}$ & $\begin{array}{l}7 \text { L09 } \\
\text { energy }\end{array}$ & $\begin{array}{l}\text { L10 } \\
\text { energy }\end{array}$ & $\begin{array}{l}\text { L11 } \\
\text { energy }\end{array}$ & $\begin{array}{l}\text { L13 } \\
\text { energy }\end{array}$ & $\begin{array}{l}\text { sum of } \\
\text { L08-L11 }\end{array}$ \\
\hline $\begin{array}{l}16: 30 \\
16: 20 \\
15: 00 \\
17: 00 \\
15: 50 \\
17: 40 \\
15: 10 \\
15: 40 \\
17: 10 \\
17: 50 \\
18: 20 \\
18: 30 \\
\text { Mean: }\end{array}$ & $\begin{array}{l}0.5 \\
0.5 \\
0.5 \\
0.5 \\
0.5 \\
0.5 \\
0.5 \\
0.5 \\
0.5 \\
0.5 \\
0.5 \\
0.5\end{array}$ & $\begin{array}{l}22.6 \\
22.9 \\
23.5 \\
23.6 \\
24.0 \\
24.3 \\
24.4 \\
24.5 \\
25.7 \\
26.3 \\
28.7 \\
29.4 \\
25.0\end{array}$ & $\begin{array}{l}246 \\
248 \\
235 \\
248 \\
260 \\
246 \\
255 \\
252 \\
256 \\
253 \\
252 \\
246 \\
250\end{array}$ & $\begin{array}{l}5.7 \\
5.8 \\
6.1 \\
6.1 \\
6.2 \\
6.3 \\
6.2 \\
6.7 \\
6.9 \\
6.9 \\
8.2 \\
8.7 \\
6.7\end{array}$ & $\begin{array}{l}5.5 \\
5.5 \\
6.2 \\
6.4 \\
6.9 \\
6.7 \\
6.5 \\
6.9 \\
7.1 \\
8.2 \\
9.2 \\
9.6 \\
7.1\end{array}$ & $\begin{array}{l}6.4 \\
6.4 \\
7 \\
7.1 \\
7.4 \\
7.3 \\
7.6 \\
7.6 \\
8.1 \\
7.5 \\
9.2 \\
9.6 \\
7.6\end{array}$ & $\begin{array}{r}6 \\
5.9 \\
6.9 \\
6.8 \\
7 \\
7.5 \\
7.7 \\
7.6 \\
7.6 \\
7.5 \\
9 \\
10.1 \\
7.5\end{array}$ & $\begin{array}{l}6.2 \\
6 \\
6.5 \\
6.7 \\
6.7 \\
7.5 \\
6.8 \\
6.8 \\
6.7 \\
6.8 \\
7.9 \\
8.4 \\
6.9\end{array}$ & $\begin{array}{r}23.6 \\
23.6 \\
26.2 \\
26.4 \\
27.5 \\
27.8 \\
28 \\
28.8 \\
29.7 \\
30.1 \\
35.6 \\
38 \\
28.8\end{array}$ \\
\hline $\begin{array}{l}14: 40 \\
16: 10 \\
14: 50 \\
16: 00 \\
15: 20 \\
15: 30 \\
16: 50 \\
16: 40 \\
17: 20 \\
17: 30 \\
18: 10 \\
18: 00 \\
\text { Mean: }\end{array}$ & $\begin{array}{l}1 \\
1 \\
1 \\
1 \\
1 \\
1 \\
1 \\
1 \\
1 \\
1 \\
1 \\
1\end{array}$ & $\begin{array}{l}21.8 \\
22.9 \\
23.1 \\
23.2 \\
23.7 \\
24.1 \\
24.4 \\
25.1 \\
27.1 \\
27.3 \\
27.6 \\
28.6 \\
24.9\end{array}$ & $\begin{array}{l}259 \\
259 \\
255 \\
252 \\
262 \\
253 \\
252 \\
252 \\
252 \\
252 \\
249 \\
250 \\
254\end{array}$ & $\begin{array}{l}4.8 \\
5.2 \\
5.3 \\
5.2 \\
5.5 \\
5.8 \\
5.4 \\
6.3 \\
7.2 \\
7.2 \\
7.5 \\
7.6 \\
6.1\end{array}$ & $\begin{array}{r}5 \\
5.6 \\
5.6 \\
5.6 \\
6.1 \\
6.3 \\
6 \\
6.4 \\
7.5 \\
7.8 \\
8.2 \\
8.3 \\
6.5\end{array}$ & $\begin{array}{r}5.2 \\
6 \\
5.8 \\
6 \\
6.2 \\
6.6 \\
6.5 \\
7.5 \\
7.9 \\
8.2 \\
9 \\
9.3 \\
7.0\end{array}$ & $\begin{array}{r}5.5 \\
6 \\
5.8 \\
6.2 \\
6 \\
6.5 \\
6.7 \\
6.8 \\
7.6 \\
7.9 \\
8.8 \\
9.4 \\
6.9\end{array}$ & $\begin{array}{l}6.1 \\
6.2 \\
5.9 \\
6.4 \\
6.3 \\
6.4 \\
6.7 \\
6.2 \\
7.2 \\
7.5 \\
8.1 \\
8 \\
6.8\end{array}$ & $\begin{array}{r}20.5 \\
22.8 \\
22.5 \\
23 \\
23.8 \\
25.2 \\
24.6 \\
27 \\
30.2 \\
31.1 \\
33.5 \\
34.6 \\
26.6\end{array}$ \\
\hline Ratio & & 99.7 & & 91.5 & 92.6 & 92.3 & 92.9 & 97.6 & 92.3 \\
\hline
\end{tabular}


significant changes occurred. The average energy ratio between the two periods for turbines L8 through L11 was $92.3 \%$. Thus, there was a $7.7 \%$ energy deficit when the half-row of upwind turbines was switched on. This is entirely consistent with the deficits measured in the direct wake tests. A clear pattern was evident within the row. The biggest change occurred at turbine L8 -- the ratio was $91.5 \%$, which is equivalent to an $8.5 \%$ energy deficit. There were slight decreases as one progressed across the row to turbine L11, which had a ratio of $92.9 \%$ or an energy deficit of $7.1 \%$. Turbine L13, at the end of the row, had the highest ratio or least deficit, $2.4 \%$. Turbine L13 was at the edge of the entire array and may have been getting more energy from the (freestream) side of the array, whereas turbine L8 was deep in the array and received none of this freestream energy. In addition, turbine L13 was downwind of turbine L6, which was always on during this test.

Using the "Student's" $t$ distribution to test for statistical significance yielded a confidence level of 0.80 for this row's energy deficit of $7.7 \%$.

\subsubsection{Summary}

The Lateral Induction Test took place on the Jess-C array. The test was designed to measure any enhancement that might occur at a turbine when turbines adjacent to it are switched on. The enhancement would occur if wind turbines create a venturi effect between their rotors. This effect could be created when wind accelerates around the rotor disk, rather than passing through it. No enhancement was measured in the test, possibly because of the spacing between turbines. The crosswind spacing was $1.9 \mathrm{D}$, which might have been too wide to see this effect. It might have been possible to see this effect with an anemometer placed between adjacent turbines, but that was beyond the scope of this test.

Wake deficits at the row downwind of the test row were examined. In this situation, the deficit is due to the effect of turning on every other turbine in the upwind row, thus reducing the crosswind spacing from 3.8 to $1.9 \mathrm{D}$. The energy deficit was $7.7 \%$, in winds of about $25 \mathrm{mph}$ at J08. This result is consistent with the energy deficits measured in the direct wake tests.

\subsection{Meandering Wake Test}

The Meandering Wake Test plan analysis was inherently more qualitative than quantitative. The test started with one turbine on at one end of the upwind row. Each hour the position of the on-line turbine moved to the next turbine. Thus, the position of the on-line turbine progressed from one end of the upwind row to the other. An additional hour of data was collected with no turbines on 1 ine in the upwind row to aid in the analysis. The analysis would determine if the wake deficit tracked through the downwind row as the position of the upwind on-line turbine changed. The individual 10-min records were also analyzed. Using the mean wind direction, one can predict where the wake trajectory should be. Downwind turbines in the expected trajectory were scrutinized to see if their energy production dropped. Because of the qualitative nature of these tests, turbine anemometer data were not analyzed. Additional discussion of the test methodology can be found in Section 2.4 .

Two Meandering Wake Tests were conducted and both tests used buffer turbines, upwind and crosswind of the array. The tests occurred on: 
1. Souza-C group, August 12, 1987, 14:50-19:50 PDT (5 h)

2. Jess-A group, August 13, 1987, 13:00-17:50 PDT (5 h)

\subsubsection{Test 1 Analysis, Souza-C, August 12, 1987}

Table 3-6.a lists the data for the August 12 test on Souza. At the bottom of the table, the overall mean statistics have been calculated for the upwind anemometer and the four test turbines. The mean wind speed at S13 was $\sim 21 \mathrm{mph}$ and ranged from about $16 \mathrm{mph}$ to $28 \mathrm{mph}$, from the west. The data are 1 isted in sequential order and grouped in "hourly" blocks. Each block of data is for one configuration at the upwind row. The column marked "config." shows which upwind turbine was on line for each data block. The mean statistics are calculated for each block or period, and the energy ratio is calculated between each period mean and the overall mean.

The energy ratios in each hourly block have been analyzed. The lowest individual ratio in each block could reveal which turbine is being affected by the wake. In the first and second time block, turbine $E 12$ has the lowest ratio and presumably is being affected by wakes. In the third time block, the lowest ratio has moved to turbine E13. This move is in the same direction as the change in upwind turbine status. In the fourth time block, the lowest ratio has moved to E14. Again, the move is in the same direction as the change in upwind status. Thus, we see to some extent that as the upwind on-line turbine progresses through the row, the apparent wake also moves through the downwind row.

The right column on the table shows where the expected wake trajectory should be, based on the 10-min wind direction. The double asterisk indicates a period when the energy production at the expected wake turbine is low and apparently affected by the wake. The 10-min energy output is considered "low" at the expected wake site by comparison with the other turbines in the row. The pattern of energy production is compared to the pattern on the bottom line of the table which is marked "overall." If there is a negative discrepancy from the overall pattern, it indicates the existence of the expected wake. This analysis is somewhat subjective and the presence of the wake has not been analyzed statistically to determine levels of significance.

The right column of Table 3-6.a shows that the expected wake should have been at turbine E10 most of the time. This was due to the unusual frequency of west winds during this test. Unfortunately, turbine E10 was a buffer turbine and was off line for the entire test, so energy data are not available. There were 11 records when $E 11$ was the expected wake location, and on only two of these there appeared to be a wake. These results are disappointing, and there are a few explanations for these results. First, the location of the wake is difficult to determine accurately. This test might be better suited for a flat terrain site with uniform wind characteristics in the test row. Second, if the wind direction at the test turbines is slightly different from the reference anemometer, then the expected trajectory will be incorrect. Wind direction data were not available at the test turbines. And, third, the expected wake turbine, E10, was not on line during this test. 
Table 3-6. a Souza-C Meandering Wake Test Analysis

Ten Minute Data Report

EOR WINDFARM: SOUZA RANCH WINDEARM

\begin{tabular}{|c|c|c|c|c|c|c|c|c|c|}
\hline $\begin{array}{l}\text { Time } \\
\text { Of Day }\end{array}$ & $\begin{array}{cc}\text { S13 } & \text { S } \\
\text { wspeed } & \text { di }\end{array}$ & & $\begin{array}{l}\text { Date: } 08 \\
\text { E11 } \\
\text { energy }\end{array}$ & $\begin{array}{l}8 / 12 / 87 \\
\text { E12 } \\
\text { energy }\end{array}$ & $\begin{array}{l}\text { E13 } \\
\text { energy }\end{array}$ & $\begin{array}{l}\text { E14 } \\
\text { energy }\end{array}$ & Confi & & $\begin{array}{l}\text { Expected } \\
\text { Wake } \\
\text { Location }\end{array}$ \\
\hline $\begin{array}{c}14: 50 \\
15: 00 \\
15: 10 \\
15: 20 \\
15: 30 \\
\text { Mean } \\
\% \text { of ove }\end{array}$ & $\begin{array}{c}16.6 \\
16.4 \\
17.4 \\
15.5 \\
16.9 \\
16.6 \\
\text { rall mean: }\end{array}$ & $\begin{array}{l}239 \\
250 \\
256 \\
248 \\
239 \\
246\end{array}$ & $\begin{array}{r}3.3 \\
3.5 \\
2.4 \\
3.1 \\
3.4 \\
3.1 \\
65.9\end{array}$ & $\begin{array}{r}3.1 \\
2.8 \\
2.0 \\
3.1 \\
3.1 \\
2.8 \\
59.4\end{array}$ & $\begin{array}{r}3.1 \\
3.0 \\
2.6 \\
2.9 \\
4.1 \\
3.1 \\
65.0\end{array}$ & $\begin{array}{r}2.3 \\
3.0 \\
2.4 \\
2.5 \\
3.9 \\
2.8 \\
68.7\end{array}$ & $\mathrm{E} 2$ & on & $\begin{array}{l}\text { E11 } \\
\text { E10 } \\
\text { E10 } \\
\text { E10 } \\
\text { E11 } \\
\text { E10 }\end{array}$ \\
\hline $\begin{array}{c}15: 50 \\
16: 00 \\
16: 10 \\
16: 20 \\
16: 30 \\
\text { Mean } \\
\% \text { of ove }\end{array}$ & $\begin{array}{c}16.3 \\
16.7 \\
16.9 \\
18 \\
17.9 \\
17.2 \\
\text { arli mean: }\end{array}$ & $\begin{array}{l}270 \\
248 \\
273 \\
273 \\
270 \\
267\end{array}$ & $\begin{array}{r}3.0 \\
3.5 \\
3.8 \\
4.9 \\
4.4 \\
3.9 \\
82.2\end{array}$ & $\begin{array}{r}3.0 \\
3.2 \\
3.5 \\
4.2 \\
3.7 \\
3.5 \\
74.2\end{array}$ & $\begin{array}{r}3.0 \\
3.5 \\
2.9 \\
4.6 \\
4.5 \\
3.7 \\
76.6\end{array}$ & $\begin{array}{r}2.5 \\
3.2 \\
2.7 \\
4.0 \\
3.8 \\
3.2 \\
78.9\end{array}$ & E3 & on & $\begin{array}{l}\text { E10 } \\
\text { E11 } \\
\text { E10 } \\
\text { E10 } \\
\text { E10 } \\
\text { E10 }\end{array}$ \\
\hline $\begin{array}{c}17: 00 \\
17: 10 \\
17: 20 \\
17: 30 \\
17: 40 \\
17: 50 \\
\text { Mean } \\
\% \text { of ove }\end{array}$ & $\begin{array}{c}16.6 \\
18.5 \\
18.8 \\
20.1 \\
22.7 \\
21.3 \\
19.7 \\
\text { eral1 mean: }\end{array}$ & $\begin{array}{l}273 \\
262 \\
273 \\
270 \\
264 \\
273 \\
269\end{array}$ & $\begin{array}{r}3.7 \\
2.4 \\
2.6 \\
4.5 \\
5.7 \\
5.3 \\
4.0 \\
84.6\end{array}$ & $\begin{array}{r}3.5 \\
2.5 \\
2.5 \\
4.3 \\
5.8 \\
5.0 \\
3.9 \\
82.9\end{array}$ & $\begin{array}{r}3.4 \\
2.9 \\
2.9 \\
3.9 \\
5.3 \\
4.3 \\
3.8 \\
78.4\end{array}$ & $\begin{array}{r}3.1 \\
2.4 \\
2.6 \\
3.2 \\
5.2 \\
4.2 \\
3.5 \\
84.0\end{array}$ & E4 & on & $\begin{array}{l}\text { E10 } \\
* * \mathrm{E} 11 * * \\
\text { E10 } \\
\text { E10 } \\
\text { E11 } \\
\text { E10 } \\
\text { E10 }\end{array}$ \\
\hline $\begin{array}{l}18: 00 \\
18: 10 \\
18: 20 \\
18: 30 \\
18: 40 \\
18: 50 \\
\quad \text { Mean } \\
\% \text { of ove }\end{array}$ & $\begin{array}{c}19.9 \\
20.8 \\
21.8 \\
22.1 \\
22.4 \\
24.9 \\
22.0 \\
\text { mal1 mean: }\end{array}$ & $\begin{array}{l}276 \\
270 \\
270 \\
270 \\
267 \\
267 \\
270\end{array}$ & $\begin{array}{r}4.3 \\
4.5 \\
5.5 \\
5.9 \\
5.9 \\
6.0 \\
5.4 \\
112.2\end{array}$ & $\begin{array}{r}4.4 \\
4.6 \\
5.7 \\
6.2 \\
5.8 \\
6.2 \\
5.5 \\
115.5\end{array}$ & $\begin{array}{r}4.1 \\
4.0 \\
5.6 \\
6.4 \\
5.6 \\
6.4 \\
5.4 \\
110.8\end{array}$ & $\begin{array}{r}2.9 \\
2.7 \\
4.2 \\
4.7 \\
3.8 \\
4.9 \\
3.9 \\
94.1\end{array}$ & E5 & on & $\begin{array}{c}\mathrm{E} 10 \\
\mathrm{E} 11 \\
\mathrm{E} 11 \\
\mathrm{E} 11 \\
\mathrm{E} 11 \\
* * \mathrm{E} 11 * * \\
\mathrm{E} 11\end{array}$ \\
\hline $\begin{aligned} 19: 00 \\
19: 10 \\
19: 20 \\
19: 30 \\
19: 40 \\
19: 50 \\
\text { Mean }\end{aligned}$ & $\begin{array}{l}24.2 \\
27.1 \\
26.1 \\
25.2 \\
28.7 \\
28.1 \\
26.6\end{array}$ & $\begin{array}{l}256 \\
273 \\
262 \\
262 \\
264 \\
264 \\
263\end{array}$ & $\begin{array}{l}6.4 \\
7.4 \\
7.3 \\
6.7 \\
7.1 \\
7.0 \\
7.0\end{array}$ & $\begin{array}{l}6.6 \\
7.7 \\
7.7 \\
7.2 \\
7.8 \\
7.7 \\
7.5\end{array}$ & $\begin{array}{l}6.7 \\
7.8 \\
7.9 \\
7.5 \\
8.2 \\
8.1 \\
7.7\end{array}$ & $\begin{array}{l}5.8 \\
7.3 \\
6.8 \\
6.5 \\
7.2 \\
7.2 \\
6.8\end{array}$ & None & on & None \\
\hline Overall & 20.6 & 264 & 4.8 & 4.7 & 4.8 & 4. 1 & & & \\
\hline
\end{tabular}


Based on the analysis of the 10 -min records, it is not clear whether the progression of the apparent wake through the row in the hourly block analysis is caused by a wake effect.

\subsubsection{Test 2 Analysis, Jess-A, August 13, 1987}

Table 3-6.b lists the data for the August 13 test on Jess-A. The format is the same as in Table 3-6.a. With the exception of the first hourly block, the winds were quite high during this test, ranging between $35 \mathrm{mph}$ and $41 \mathrm{mph}$ at J08. Using the first analysis approach, analyzing the data in hourly blocks, turbine $\mathrm{K} 3$ has the lowest ratio when turbine F10 is on. In subsequent hourly blocks, it is difficult to track the "wake." In the next block, turbine K6 has the lowest ratio, and this is followed by $k 7$ in the next period. These changes are in the same directional sense as the changes in the upwind row. However, the ratios at the "affected" turbines are only $\sim 2 \%$ lower than the adjacent turbines. In the last time period, the lowest ratio moves back to turbine $\mathrm{K} 4$, which is not in the same progression as the upwind row status. It is probable that the high winds masked the wake effect in this test case.

Analysis of the individual 10-min data shows that there were only two records when an expected wake location could be predicted. The wind speeds were too high after the 14:30 record to expect to see a wake deficit. of these two records, one had an apparent wake at the expected location. If the winds had been lower, the results from this test might have been more encouraging.

\subsubsection{Summary}

Two meandering wake tests were conducted, and in both cases the results were inconclusive. In one test, the winds were too high to see a wake deficit. In the other test, the expected wake impinged on a buffer turbine that was not on line. This type of test does not necessarily lend itself to rigorous statistical analysis. To be certain about the expected wake trajectory, this test is better suited for a test array on flat terrain with several wind direction sensors throughout the array.

\subsection{Northwest or Parallel Case}

Data have been analyzed from five rows of Nordtank $65 / 13 \mathrm{~kW}$ turbines on the Souza Ranch and three on the Jess Ranch to calculate wake energy deficits associated with "northwest" or winds parallel to rows. The rows are oriented along an axis from approximately north-northwest to south-southeast as shown in Figures 2-1 and 3-7. Spacing within rows is $1.9 \mathrm{D}$, and there are four to eight turbines in each of the rows examined.

The data periods analyzed were from November 1986 through April 1987 and from November 1987 through April 1988. Fewer northwest winds occur in the central Altamont, where the Jess Ranch is located, than in northern Altamont, where the Souza Ranch is located. This difference may be due in part to wake effects. In northwest winds, the Jess Ranch is downwind of many miles of turbines, whereas the Souza Ranch is upwind of these turbines. Based on research by this author, Nierenberg (1987), not related to this study, there is evidence that wake energy deficits from large arrays of turbines persist for several miles in the Altamont Pass. The wake energy deficit from a $50 \mathrm{MW}$ wind turbine array was measured as far downwind as three miles $(250 \mathrm{D})$. The energy deficit at this distance was approximately $10 \%$. 
Table 3-6. b Jess-A Meandering Wake Test Analysis

Ten Minute Data Report

FOR WINDEARM: JESS RANCH WINDFARM

\begin{tabular}{|c|c|c|c|c|c|c|c|c|c|}
\hline $\begin{array}{l}\text { REPORT } \\
\text { Time } \\
\text { of Day }\end{array}$ & $\begin{array}{l}\text { J08 } \\
\text { wspeed }\end{array}$ & $\begin{array}{l}\text { J08 } \\
\text { w. dir. }\end{array}$ & $\begin{array}{l}\text { K03 } \\
\text { energy }\end{array}$ & $\begin{array}{l}08 / 13 / 8 \\
\text { KO4 } \\
\text { energy }\end{array}$ & $\begin{array}{l}\text { K05 } \\
\text { energy }\end{array}$ & $\begin{array}{l}\text { K06 } \\
\text { energy }\end{array}$ & $\begin{array}{l}\text { K07 } \\
\text { energy }\end{array}$ & Config. & $\begin{array}{l}\text { Expected } \\
\text { Wake } \\
\text { Location }\end{array}$ \\
\hline $\begin{array}{l}13: 00 \\
13: 10 \\
13: 20 \\
13: 30 \\
\text { Mean: }\end{array}$ & $\begin{array}{l}14.4 \\
17.6 \\
16.4 \\
18.3 \\
16.7\end{array}$ & $\begin{array}{l}248 \\
248 \\
248 \\
225 \\
242\end{array}$ & $\begin{array}{l}1.0 \\
1.1 \\
2.5 \\
0.3 \\
1.2\end{array}$ & $\begin{array}{l}0.7 \\
1.3 \\
2.7 \\
0.7 \\
1.4\end{array}$ & $\begin{array}{l}0.9 \\
1.4 \\
2.8 \\
0.9 \\
1.5\end{array}$ & $\begin{array}{l}0.7 \\
1.4 \\
2.3 \\
1.2 \\
1.4\end{array}$ & $\begin{array}{l}0.6 \\
1.2 \\
2.2 \\
1.2 \\
1.3\end{array}$ & None on & None \\
\hline $\begin{array}{l}14: 20 \\
14: 30 \\
14: 40 \\
14: 50 \\
\text { Mean: } \\
\% \text { of }\end{array}$ & $\begin{array}{r}31.9 \\
30.3 \\
36.2 \\
40.8 \\
34.8 \\
\text { all me }\end{array}$ & $\begin{array}{l}225 \\
225 \\
225 \\
225 \\
225\end{array}$ & $\begin{array}{r}7.2 \\
5.8 \\
7.4 \\
8.3 \\
7.2 \\
90.9\end{array}$ & $\begin{array}{r}8.0 \\
5.7 \\
6.8 \\
8.5 \\
7.3 \\
92.8\end{array}$ & $\begin{array}{r}9.0 \\
5.5 \\
6.4 \\
9.1 \\
7.5 \\
95.2\end{array}$ & $\begin{array}{r}8.9 \\
5.6 \\
6.4 \\
9.8 \\
7.7 \\
96.3\end{array}$ & $\begin{array}{r}8.6 \\
6.0 \\
7.1 \\
9.8 \\
7.9 \\
98.0\end{array}$ & F10 on & $\begin{array}{l}\mathrm{K} 4+\mathrm{K} 5 \\
* * \mathrm{~K} 4+\mathrm{K} 5 * \\
\text { too windy } \\
" 1 " \\
" 1 \\
" \quad "\end{array}$ \\
\hline
\end{tabular}

$\%$ of overall mean:

$\begin{array}{lllll}90.9 & 92.8 & 95.2 & 96.3 & 98.0\end{array}$

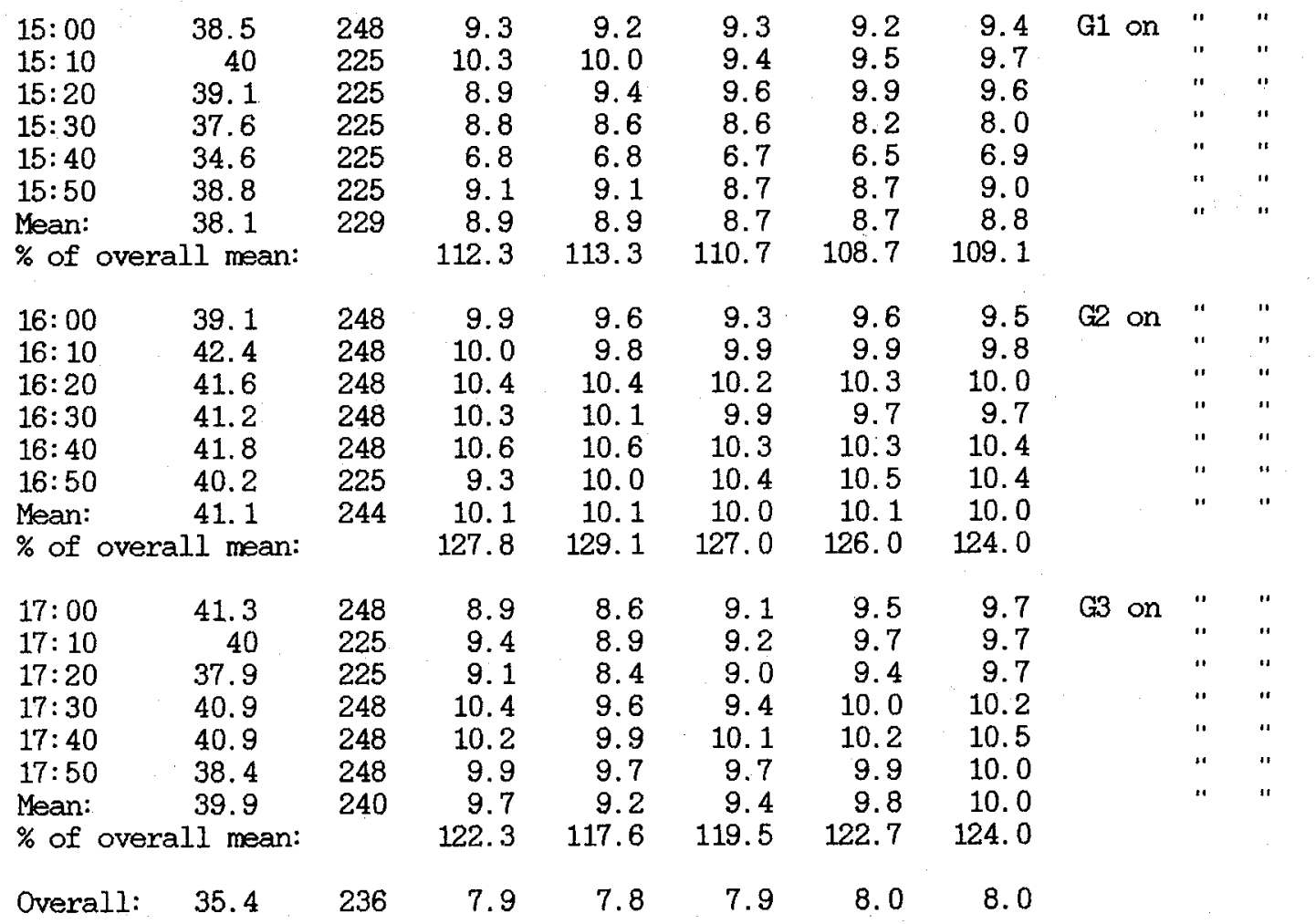

** Indicates apparent wake is at expected location. 


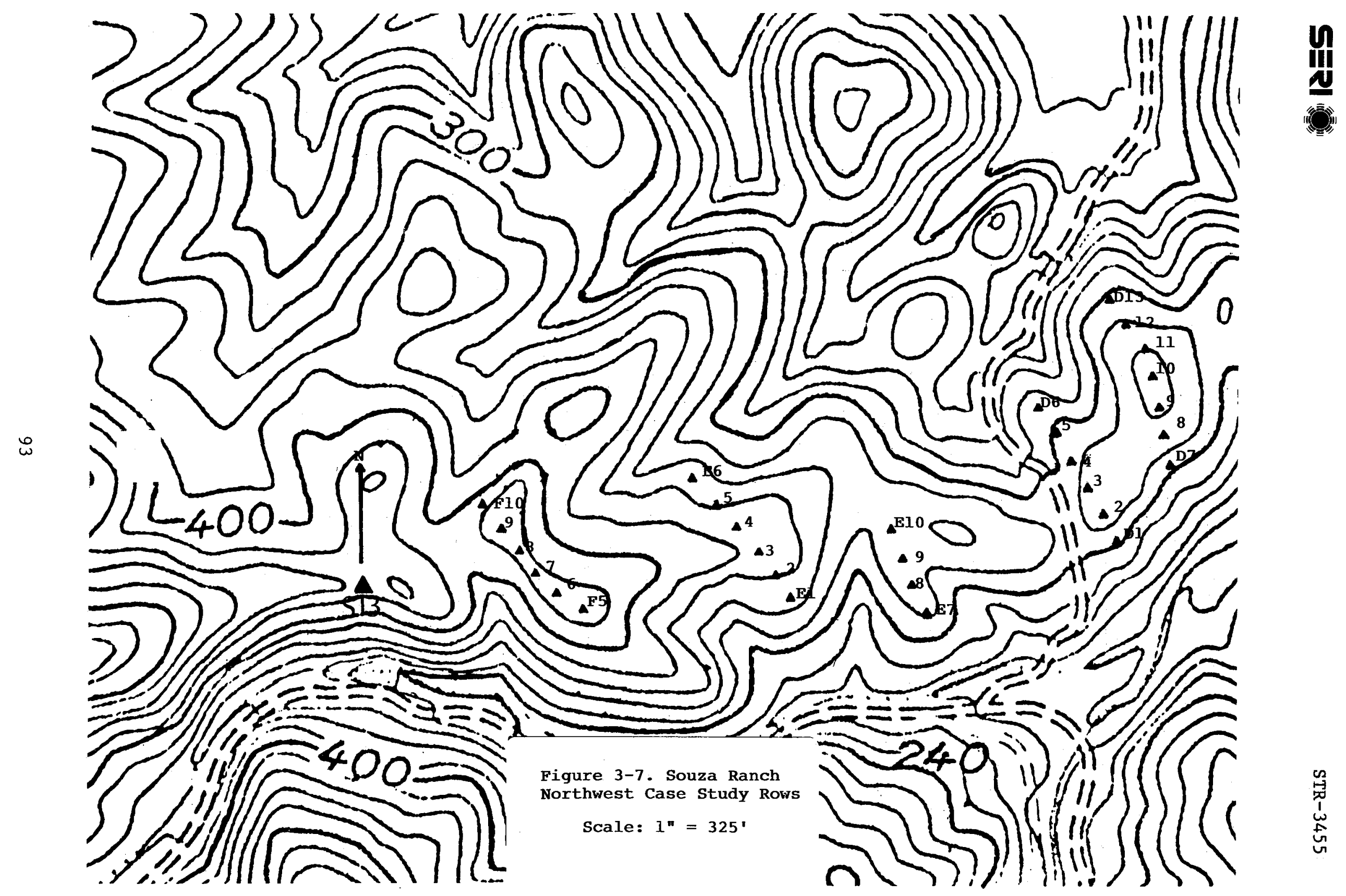


In the winter period of 1986-87, there were too few power-producing northwest winds on the Jess ranch to warrant analysis. However, there were stronger and more frequent northwest winds in winter 1987-88 on both ranches. Therefore, only one winter was analyzed on Jess and two winters on Souza. The winter/ spring season is when most of the north-northwesterly power-producing winds occur. The data analyzed were 10-min mean energy output at the turbines, and mean wind speed and direction at the reference tower.

For each winter season (November through April), the 30 days with the highest occurrence of northwest power-producing winds were analyzed. In the winter of 1986-87, there were about 160 hours of northwest power-producing winds on the days analyzed, and in the winter of 1987-88, there were 430 hours on the Souza Ranch. During the 1987-88 winter, there were about 190 hours on the Jess Ranch. The dates selected for this analysis were chosen at the end of the winter season. The parallel case studies were not attended tests like the previous wake cases. No personnel were present to verify conditions visually, such as alignment of rows with actual wind directions.

After the analysis days were selected, turbine availability was determined. If a turbine was available less than about $70 \%$, it was not included in the analysis. In a few cases, several turbines within a row did not meet this criteria, so the entire row was excluded from the analysis.

Figure 3-7 shows that the turbine rows on Souza are on complex terrain. Within most rows, the highest terrain is found in the middle of the row with elevation dropping off at either end. The rows on Souza are not all parallel to one another. In order to ensure that the wind direction band was parallel to each row, slightly different bands were analyzed for each row. Figure 2-1 shows that the terrain on Jess is also moderately complex. The L7-L13 row, like Souza, has the highest terrain in the middle of the row. The next row, M1-M7, slopes steadily downward from the upwind turbine (M7). The last row, N1-M13, has the lowest terrain in the middle of the row. In northwest winds in the Altamont Pass, elevation generally enhances wind speed. Thus, there could be terrain speed-up effects on the order of $5 \%$ in the data analyzed. These effects, which have not been quantified, may either enhance or suppress in-1ine wake deficits. A speed-up effect of $5 \%$ is roughly equivalent to an energy increase of $10 \%$; therefore, this could be considered the noise level of this analysis.

The 10-min energy production data from the second through nth turbine in each row, were correlated to the upwind (northernmost) turbine in each row. Correlation coefficients and energy ratios were calculated. If the upwind turbine in a given row was available less than the row average, typically $85 \%$, it was not used, because the reference turbine should have high availability.

\subsubsection{6-87 Souza Ranch Data}

Table 3-7.a summarizes the data analyzed on a row-by-row basis for the first period, 1986-87. The table lists the turbine row, stratification class, sample size and mean energy ratio of the downwind turbines to the upwind turbines. Data were stratified by wind direction into three $22 \frac{1}{2}^{\circ}$ bins, one bin parallel to the row and one bin on either side of this direction band. Twenty-two-and-a-half-degree bins are equivalent to one 16-point compass sector. During the 1986-87 winter, the central monitoring computer archived 
the wind direction data to the nearest $22 \frac{1}{2}^{\circ}$. This was changed in summer 1987 so that the wind direction data were stored to the nearest tenth of a degree.

Table 3-7.a shows that three rows were analyzed in 1986-87. The two D rows were excluded because of availability problems. Almost all ratios are less than unity, with the exception of the E7-E10 row. (This portion of the E row was analyzed because there is a kink in the row at E10, and turbines E11-E14 are on a slightly different axis.) Note that the lowest ratios do not always occur in the parallel wind direction band. In two of the three rows, the ratios are lower (and deficits are higher) in the $+22 \frac{1}{2}{ }^{\circ}$ band. These results could have been caused by an alignment error in the wind vane. If there was an alignment error, there is no way to determine this at this date, as the sensor was replaced in summer 1987. Subsequent analysis of the 1987-88 data (see next section), suggests that there could have been an alignment problem with the wind vane, as the 1987-88 data showed maximum deficits in the parallel direction band. The poor resolution $\left(22^{\frac{1}{2}}{ }^{\circ}\right)$ of the $1986-87$ wind direction data may also introduce some error. In addition, because there was only one wind direction vane on each ranch, one cannot state with certainty how representative the reference site direction is of each individual row. The assumption has been made that these data are representative, but local terrain effects can cause wind direction shifts at these sites. These tests were unattended, so there is no way to verify that these direction data are representative.

Table 3-7.a Northwest or Parallel Case Summary: November 1986 - April 1987, Souza Ranch

\begin{tabular}{|c|c|c|c|c|c|}
\hline \multicolumn{2}{|c|}{$\begin{array}{l}\text { Upwind } \\
\text { Turbine }\end{array}$} & $\begin{array}{l}\text { Downwind } \\
\text { Turbines }\end{array}$ & $\begin{array}{l}\text { Stratificationl } \\
\text { Wind } \\
\text { Direction }\end{array}$ & $\begin{array}{l}\text { Sample2 } \\
\text { Size }\end{array}$ & $\begin{array}{l}\text { Mean Energy } \\
\text { Ratio (\%) to } \\
\text { Upwind Turbine }\end{array}$ \\
\hline $\begin{array}{l}\text { E6 } \\
11 \\
11\end{array}$ & $"$ & ${ }^{1 "}$ & $\begin{array}{c}\text { Parallel } \\
-22 \frac{1}{2} 0^{\circ} \\
+22 \frac{1^{\circ}}{2}\end{array}$ & $\begin{array}{r}65 \\
89 \\
400\end{array}$ & $\begin{array}{l}67.9 \% \\
80.6 \\
97.4\end{array}$ \\
\hline $\begin{array}{l}\text { E10 } \\
" 1 \\
\text { " }\end{array}$ & " & $\begin{array}{l}\text { E7-E9 } \\
" 1\end{array}$ & $\begin{array}{l}\text { Parallel } \\
\quad-22 \frac{1}{2} 0^{\circ} \\
\quad+22 \frac{1}{2} 0^{\circ}\end{array}$ & $\begin{array}{r}400 \\
65 \\
519\end{array}$ & $\begin{array}{r}91.1 \\
144.3 \\
42.2\end{array}$ \\
\hline $\begin{array}{l}\text { F10 } \\
\text { "1 } \\
\text { " }\end{array}$ & $"$ & $\begin{array}{l}\text { "F5-F9 } \\
" 1\end{array}$ & $\begin{array}{c}\text { Parallel } \\
\quad-22 \frac{1}{2}^{\circ} \\
+22 \frac{1}{2} 0^{\circ}\end{array}$ & $\begin{array}{r}65 \\
89 \\
400\end{array}$ & $\begin{array}{l}77.4 \\
94.8 \\
34.7\end{array}$ \\
\hline
\end{tabular}

NOTES :

1. $-22 \frac{1}{2}$ indicates direction band with more westerly component, $+22 \frac{1}{2}{ }^{\circ}$ is more northerly as measured at $\mathrm{S} 13$ tower. Note that S13 is only 2 D downwind of operating turbines in northwest winds and therefore is in the "near wake" of turbines G5 or G6.

2. Sample size in 10-minute means. 
Weighted mean energy ratios have been calculated for these three rows (weighted by sample size). Table 3-7.b lists these weighted mean energy ratios and the energy deficit, defined as $100 \%$ minus the energy ratio in percent.

Table 3-7.b shows that the weighted mean energy deficit, assuming negligible terrain effects, is $30.4 \%$. The table also shows that the deficit is higher, $43.4 \%$, for the $+22 \frac{1}{2}^{\circ}$ band. There is no deficit for the $-22 \frac{1}{2}$ band, again suggesting a possible wind vane alignment problem.

The raw data sheets summarized by Tables $3-7 . a$ and $3-7 . b$ are contained in Appendix A. There is a table for each line of data in Table 3-7.a. Each table lists the following information:

1) Screening parameters such as speed, direction, or time of day

2) Turbines analyzed

3) Correlation coefficient to upwind turbine

4) 10-min mean energy output at each turbine

5) Energy ratio to upwind turbine

6) Sample size

7) Turbine availability (1isted on the first table of each set only).

The tables contained in Appendix A are sorted by:

1) Year (ascending order)

2) Ranch (Souza followed by Jess)

3) Turbine strings (alphabetical order)

4) Stratification type
a) wind direction ( 3 tables)
b) wind speed ( 3 tables)
c) time-of-day (2 tables)

Table 3-7.b Weighted Mean Energy Ratios for 1986-87 Souza Ranch Northwest Case Data

\begin{tabular}{lcc}
\hline Wind Direction Band & Energy Ratio (\%) & Deficit (\%) \\
Paralle1 & $86.6 \%$ & $13.4 \%$ \\
$-22 \frac{1}{2^{\circ}}$ & 102.8 & $<<2.8>$ \\
$+22 \frac{1}{2^{\circ}}$ & 56.6 & 43.4 \\
Mean & 69.6 & 30.4 \\
\hline
\end{tabular}


For each row of turbines analyzed, there are a minimum of three tables -- the parallel wind direction followed by the $-22 \frac{1}{2}{ }^{\circ}$ bin and then the $+22 \frac{1}{2}{ }^{\circ}$ bin. A number of turbine rows had additional analyses done on the parallel wind direction bin. The sequence of these tables is low, moderate, and high windspeed class. These tables are followed by two more, sorted by time into daylight and nightime hours. The appendix contains a total of 72 tables: Tables 3-7.1a through 3-7.1r contain the 1986-87 Souza Ranch data. Tables 3-7.2a through 3-7.2nn contain the 1987-88 Souza Ranch data. Tables 3-7.3a through 3-7.3n contain the 1987-88 Jess Ranch data.

The "reference" turbine is the upwind turbine and the "referred" turbines are the downwind turbines. Note that the listings of the referred turbines are in numerical order, which is the opposite order of their placement within the row. These tables contain a great deal of information useful for detailed analysis. For example, if a turbine had a low availability, the turbine immediately downwind usually had a higher energy output and energy ratio. There was no universal pattern within rows. It is not possible to say that the nth turbine in each row had the lowest energy output. The 1986-87 tables contain some additional analysis of the E-rows, including stratification by wind speed and time of day. These will be discussed at length in the 1987-88 analysis.

\subsubsection{7-88 Souza Ranch Data}

The 1987-88 winter season had a higher frequency of occurrence of northwest winds than the 1986-87 winter season. Five rows of turbines were analyzed on the Souza Ranch, and Table 3-7.c summarizes the results.

Table 3-7.c shows that the weighted mean energy ratio for the parallel direction is $57.9 \%$, or the energy deficit is $42.1 \%$. The two neighboring direction bands have higher energy ratios, i.e., lower deficits. This is a more reasonable result than obtained in the 1986-87 analysis in the previous section. One would expect the deficits to be highest when the wind direction is parallel to the row. The deficits are higher in this season than in the first season analyzed.

Because the sample sizes were larger in the 1987-88 season, some additional analysis was done. The data from these rows were stratified by wind speed and time of day. Table 3-7.d summarizes these data.

Table 3-7.d shows that stratification by time of day has slightly more impact than stratifying by speed. The daytime ratios at all rows have higher energy ratios (lower deficits) than all hours. The opposite is true for night -- the ratios are lower; i.e., deficits are higher. On the average, the deficits are $19 \%$ higher at night versus day. There are two probable explanations. One could be atmospheric stability. There is generally more instability in the daytime, which promotes more vertical mixing of horizontal momentum and quicker diffusion of the wake. The other explanation is speed. In most of the daytime samples, the upwind turbine had a higher mean energy output, i.e., higher mean speed, than the nighttime means. The higher daytime speeds would yield lower deficits. 
Table 3-7.c Northwest or Para1lel Case Summary: November 1987 - April 1988, Souza Ranch

\begin{tabular}{|c|c|c|c|c|}
\hline $\begin{array}{l}\text { Upwind } \\
\text { Turbine }\end{array}$ & $\begin{array}{l}\text { Downwind } \\
\text { Turbines }\end{array}$ & $\begin{array}{c}\text { Stratification } \\
\text { Wind } \\
\text { Direction }\end{array}$ & $\begin{array}{c}\text { Sample } \\
\text { Size }\end{array}$ & $\begin{array}{l}\text { Mean Energy } \\
\text { Ratio (\%) To } \\
\text { Upwind Turbine }\end{array}$ \\
\hline $\begin{array}{l}\text { D6 } \\
" 1 \\
" 1\end{array}$ & $\begin{array}{c}\text { D1-D4 } \\
" " ~ \\
" ~\end{array}$ & $\begin{array}{l}\text { Parallel } \\
\quad-22 \frac{1}{2}^{\circ} \\
+22 \frac{1}{2} \frac{1}{0}^{\circ}\end{array}$ & $\begin{array}{r}1614 \\
685 \\
398\end{array}$ & $\begin{array}{l}47.1 \% \\
36.7 \\
69.7\end{array}$ \\
\hline $\begin{array}{l}\text { D13 } \\
" 1 "\end{array}$ & $\begin{array}{l}\text { D7-D11 } \\
" " ~ \\
" "\end{array}$ & $\begin{array}{l}\text { Paral1el } \\
-22 \frac{1}{2} 0^{\circ} \\
+22 \frac{1}{2} 0^{\circ}\end{array}$ & $\begin{array}{r}1406 \\
158 \\
990\end{array}$ & $\begin{array}{l}50.6 \\
77.5 \\
72.2\end{array}$ \\
\hline $\begin{array}{l}\text { E6 } \\
\text { "1 } \\
\text { " }\end{array}$ & $\begin{array}{c}\text { E1-E5 } \\
" 1 " \\
" 1 "\end{array}$ & $\begin{array}{l}\text { Parallel } \\
\quad-22 \frac{1}{1^{\circ}} \\
\quad+22 \frac{1}{2}^{\circ}\end{array}$ & $\begin{array}{r}896 \\
82 \\
1426\end{array}$ & $\begin{array}{r}81.6 \\
69.4 \\
101.6\end{array}$ \\
\hline $\begin{array}{l}\text { E10 } \\
" 1 \\
" 1\end{array}$ & $\begin{array}{c}\text { E7-E9 } \\
" 1 " \\
" " ~\end{array}$ & $\begin{array}{c}\text { Parallel } \\
-222^{1} 0^{\circ} \\
+22 \frac{12^{\circ}}{2}\end{array}$ & $\begin{array}{r}898 \\
1510 \\
205\end{array}$ & $\begin{array}{l}45.2 \\
68.5 \\
53.8\end{array}$ \\
\hline $\begin{array}{l}\text { F9 } \\
" 1 \\
" 1\end{array}$ & $\begin{array}{c}\text { F5-F8 } \\
" ~ " ~ \\
" ~ " ~\end{array}$ & $\begin{array}{c}\text { Parallel } \\
\quad-22^{\frac{1}{2}} 0^{\circ} \\
\quad+22 \frac{1}{2}^{\circ}\end{array}$ & $\begin{array}{r}1310 \\
227 \\
467\end{array}$ & $\begin{array}{l}71.7 \\
91.9 \\
86.2\end{array}$ \\
\hline $\begin{array}{r}\text { Weighted } \\
-22^{\frac{1}{2}}{ }^{\circ} \\
+22^{\frac{1}{2}}{ }^{\circ}\end{array}$ & Means: & $\begin{array}{c}\text { Parallel } \\
62.9 \\
84.7\end{array}$ & & $57.9 \%$ \\
\hline
\end{tabular}

The stratification by speed shows that there are higher deficits in lower winds. On the average, the ratios increase (deficits decrease) by $9 \%$ in winds above $25 \mathrm{mph}$ versus the all-winds case. The deficits increase by $5 \%$ in winds below $25 \mathrm{mph}$. This is the expected result based on the inverse relationship between speed and wake deficits, which was discussed in earlier sections.

\subsubsection{7-88 Jess Ranch Data}

Data from three rows on the Jess Ranch were analyzed from the winter of 1987-88. Table 3-7.e summarizes these data.

The table shows that the mean energy ratio for parallel winds is $56.9 \%$, or the energy deficit is $43.1 \%$. The deficits for the two neighboring directions are $6 \%$ to $9 \%$ lower. The M8 row data were stratified by wind speed and time of day. This row was analyzed because it had the highest overall availability. Table 3-7.f summarizes the data.

The table shows similar results to the Souza data contained in Table 3-7.d. Deficits are lower in the daytime than at nighttime. The deficits decrease in higher winds and increase in lower winds. 
Table 3-7.d Stratification by Wind Speed and Time of Day

\begin{tabular}{|c|c|c|c|c|}
\hline $\begin{array}{l}\text { Upwind } \\
\text { Turbine }\end{array}$ & $\begin{array}{l}\text { Wind } \\
\text { Direction }\end{array}$ & $\begin{array}{l}\text { Other } \\
\text { Stratification }\end{array}$ & $\begin{array}{l}\text { Sample } \\
\text { Size }\end{array}$ & $\begin{array}{l}\text { Mean Energy } \\
\text { Ratio }(\%)\end{array}$ \\
\hline $\begin{array}{l}\text { D6 } \\
" 1 " \\
" \\
"\end{array}$ & $\begin{array}{c}\text { Para11el } \\
\text { " " } \\
" 1 " \\
" 1 "\end{array}$ & $\begin{array}{l}\text { Al1 data } \\
\text { Daytime } \\
\text { Nightime } \\
\text { Winds above } 25 \mathrm{mph} \\
\text { Winds below } 25 \mathrm{mph}\end{array}$ & $\begin{array}{r}1614 \\
496 \\
696 \\
525 \\
1095\end{array}$ & $\begin{array}{l}47.1 \% \\
59.8 \\
38.4 \\
50.8 \\
42.8\end{array}$ \\
\hline $\begin{array}{l}\text { D13 } \\
" 1 \\
" 1 \\
" 1\end{array}$ & $\begin{array}{c}\text { Parallel } \\
\text { " } \\
" 1 " \\
" 1 " \\
" \text { " }\end{array}$ & $\begin{array}{l}\text { Al1 data } \\
\text { Daytime } \\
\text { Nightime } \\
\text { Winds above } 25 \mathrm{mph} \\
\text { Winds below } 25 \mathrm{mph}\end{array}$ & $\begin{array}{r}1406 \\
215 \\
803 \\
228 \\
1181\end{array}$ & $\begin{array}{l}50.6 \% \\
62.3 \\
47.3 \\
67.2 \\
45.2\end{array}$ \\
\hline $\begin{array}{l}\mathrm{E} 6 \\
" 1 \\
" 1 \\
"\end{array}$ & $\begin{array}{c}\text { Parallel } \\
\text { " " } \\
" 1 \\
\text { " " " }\end{array}$ & $\begin{array}{l}\text { All data } \\
\text { Daytime } \\
\text { Nightime } \\
\text { Winds above } 25 \mathrm{mph} \\
\text { Winds below } 25 \mathrm{mph}\end{array}$ & $\begin{array}{r}896 \\
94 \\
576 \\
75 \\
823\end{array}$ & $\begin{array}{l}81.6 \% \\
93.7 \\
80.2 \\
94.7 \\
77.7\end{array}$ \\
\hline $\begin{array}{l}\text { E10 } \\
" 1 \\
11 \\
" 1 \\
" 1\end{array}$ & $\begin{array}{c}\text { Parallel } \\
" \text { " } \\
" 1 \\
" 1 "\end{array}$ & $\begin{array}{l}\text { Al1 data } \\
\text { Daytime } \\
\text { Nightime } \\
\text { Winds above } 25 \mathrm{mph} \\
\text { Winds below } 25 \mathrm{mph}\end{array}$ & $\begin{array}{l}898 \\
556 \\
187 \\
422 \\
479\end{array}$ & $\begin{array}{l}45.2 \% \\
48.4 \\
37.2 \\
51.0 \\
35.1\end{array}$ \\
\hline $\begin{array}{l}\text { F9 } \\
\text { "1 } \\
\text { " } \\
\text { " }\end{array}$ & $\begin{array}{c}\text { Para11e1 } \\
\text { " } \\
" 1 " \\
" 1 " \\
\text { " " }\end{array}$ & $\begin{array}{l}\text { Al1 data } \\
\text { Daytime } \\
\text { Nightime } \\
\text { Winds above } 25 \mathrm{mph} \\
\text { Winds below } 25 \mathrm{mph}\end{array}$ & $\begin{array}{r}1310 \\
293 \\
652 \\
292 \\
1021\end{array}$ & $\begin{array}{l}71.7 \% \\
94.0 \\
62.2 \\
75.8 \\
68.0\end{array}$ \\
\hline $\begin{array}{l}\text { Mean } \\
\text { "1 } \\
\text { "1 } \\
\text { "1 }\end{array}$ & $\begin{array}{c}\text { Parallel } \\
\text { " " } \\
" 1 " \\
" 1 "\end{array}$ & $\begin{array}{l}\text { Al1 data } \\
\text { Daytime } \\
\text { Nightime } \\
\text { Winds above } 25 \mathrm{mph} \\
\text { Winds below } 25 \mathrm{mph}\end{array}$ & & $\begin{array}{l}59.2 \% \\
71.6 \\
53.1 \\
67.9 \\
53.8\end{array}$ \\
\hline
\end{tabular}

\subsubsection{Summary}

Three sets of data have been analyzed -- two seasons on Souza and one on Jess. The results obtained on Souza in 1986-87 raised some doubts about wind vane orientation, so this summary will focus on the 1987-88 data. It is important to note two points. First, the analysis is of energy production data that were collected during routine operations, not in a controlled test environment. There are factors other than wakes that can affect the energy ratios, notably terrain speed-up effects. It was suggested that this effect could be on the order of $\pm 10 \%$. No attempt has been made to account for or normalize these effects. Second, turbine availability was not $100 \%$. There is 
Table 3-7.e Northwest or Parallel Case Summary: November 1987 - April 1988, Jess Ranch

\begin{tabular}{|c|c|c|c|c|}
\hline \multicolumn{2}{|c|}{------ Row-- -----} & \multirow{2}{*}{$\begin{array}{l}\text { Mean Energy } \\
\text { Wind } \\
\text { Direction }\end{array}$} & \multirow[b]{2}{*}{$\begin{array}{l}\text { Sample } \\
\text { Size }\end{array}$} & \multirow[b]{2}{*}{$\begin{array}{l}\text { Ratio (\%) To } \\
\text { Upwind Turbine }\end{array}$} \\
\hline $\begin{array}{l}\text { Upwind } \\
\text { Turbine }\end{array}$ & $\begin{array}{l}\text { Downwind } \\
\text { Turbines }\end{array}$ & & & \\
\hline $\begin{array}{l}\text { L13 } \\
" 1 \\
" 1\end{array}$ & $\begin{array}{l}\text { L7-L12 } \\
" \text { " } \\
" "\end{array}$ & $\begin{array}{l}\text { Paralle } \\
\quad-22 \frac{1}{2} 0^{\circ} \\
\quad+22 \frac{1}{2} 0^{\circ}\end{array}$ & $\begin{array}{l}538 \\
466 \\
120\end{array}$ & $\begin{array}{l}71.2 \\
88.8 \\
74.1\end{array}$ \\
\hline $\begin{array}{l}\text { M8 } \\
" 1 \\
\text { " }\end{array}$ & $\begin{array}{l}\text { M1-M7 } \\
" " ~ \\
" "\end{array}$ & $\begin{array}{l}\text { Paralle1 } \\
-22 \frac{1}{2} 0^{\circ} \\
+22 \frac{1}{2} 0^{\circ}\end{array}$ & $\begin{array}{r}499 \\
402 \\
98\end{array}$ & $\begin{array}{l}47.3 \\
53.1 \\
52.7\end{array}$ \\
\hline $\begin{array}{l}\text { M13 } \\
" 1\end{array}$ & $\begin{array}{ccc}\mathrm{M9-M11}, & \mathrm{N} 1-\mathrm{N} 3 \\
" & " 1 & " 1\end{array}$ & $\begin{array}{l}\text { Parallel } \\
-22 \frac{1}{2}^{\circ} \\
+22 \frac{1}{2} 0^{\circ}\end{array}$ & $\begin{array}{l}540 \\
481 \\
120\end{array}$ & $\begin{array}{l}51.6 \\
52.7 \\
59.7\end{array}$ \\
\hline $\begin{array}{r}\text { Weighted } \\
-22^{\frac{1}{2}}{ }^{\circ} \\
+22 \frac{1}{2}^{\circ}\end{array}$ & Means : & $\begin{array}{c}\text { Para11e1 } \\
\quad 65.6 \\
62.8\end{array}$ & & 56.9 \\
\hline
\end{tabular}

Table 3-7.f Stratification of Jess M8 Row by Wind Speed and Time of Day

\begin{tabular}{lllc}
\hline Stratification & $\begin{array}{l}\text { Sample } \\
\text { Size }\end{array}$ & $\begin{array}{l}\text { Mean Energy } \\
\text { Ratio(\%) }\end{array}$ & Deficit(\%) \\
\hline Al1 data & 499 & $47.3 \%$ & $52.7 \%$ \\
Daytime & 235 & 53.4 & 46.6 \\
Nightime & 147 & 40.6 & 59.4 \\
Winds above 25 mph & 118 & 63.9 & 36.1 \\
Winds below 25 mph & 405 & 40.7 & 59.3 \\
\hline
\end{tabular}

an inverse relationship between availability and the wake deficits. If a turbine is not operating in the middle of a row, the turbine immediately downwind of it often has increased energy output resulting in a lower deficit. Turbine availability, on the days analyzed with northwest winds, was about $84 \%$. It is not known if the relationship between availability and deficits is linear, but if it is, we could expect a $16 \%$ increase in overall deficits. With these two caveats in mind, the data from the tables above can be summarized. Table 3-7.g summarizes the 1987-88 data from both ranches, stratified by wind direction bins.

The table shows that the weighted mean energy deficit is $42.3 \%$ for winds blowing parallel to the row axis. It is not known why the two off-axis bins 
Table 3-7.g Weighted Mean Energy Deficits, Souza and Jess Ranches

\begin{tabular}{lccc}
\hline Stratification & Souza & Jess & Weighted \\
Parallel & $1987-88$ & $1987-88$ & Mean Deficit \\
$-22 \frac{1}{2} 0^{\circ}$ & $42.1 \%$ & $43.1 \%$ & $42.3 \%$ \\
$+22 \frac{1}{2}$ & $37.1 \%$ & $34.4 \%$ & $36.5 \%$ \\
Sample size & $15.3 \%$ & $37.2 \%$ & $19.9 \%$ \\
\hline
\end{tabular}

have different energy deficits. The Jess Ranch deficits are more symmetric about the parallel bin than the souza deficits. If the two off-axis deficits are combined, the mean off-axis energy deficit is $28.2 \%$. This is exactly twothirds of the mean parallel deficit of $42.3 \%$.

If these deficits are normalized by $116 \%$ as a rough accounting for the effects of availability, the resulting mean deficits are:

$$
\begin{aligned}
& \text { parallel to axis }=49.1 \% \\
& 22 \frac{1}{2^{\circ}} \text { off-axis }=32.7 \%
\end{aligned}
$$

Because the noise level of this exercise introduced by terrain speed-up effects is approximately $\pm 10 \%$, the above deficits should be rounded of $f$ to:

$$
\begin{aligned}
& \text { parallel to axis }=1 / 2 \text { or } 50 \% \\
& 22 \frac{1}{2}^{\circ} \text { off-axis }=1 / 3 \text { or } 33 \%
\end{aligned}
$$

These calculations are based on the assumption that the net terrain effect is negligible. 


\section{SECTION 4.0 CONCLUSIONS}

A variety of tests were conducted on three Nordtank $65-\mathrm{kW}$ wind turbine arrays in the Altamont Pass. Spacing within the arrays was $1.9 \mathrm{D}$ in the lateral direction by about $8 \mathrm{D}$ in the downwind direction. Approximately $125 \mathrm{~h}$ of data were collected and analyzed. Most of the test scenarios were designed to measure the effects or deficits of one row of turbines on another. In a few tests, the incremental effects of up to three rows were measured.

In the basic scenario, the Direct Wake Effect, six tests were conducted. The mean row energy deficit was $12.3 \%$ at approximately $8 \mathrm{D}$. Higher deficits were measured in lower wind speeds and deficits of about $4 \%$ were measured in winds above $30 \mathrm{mph}$. Figure $4-1$ is a plot of the mean row and maximum individual turbine deficits versus wind speed for each test. The figure includes data from the direct wake tests, the $16 \mathrm{D}$ tests, and the portions of the multiple row tests that are applicable (one row on). Mean row deficits are plotted as squares, and the maximum individual turbine deficits from each test are plotted as plus signs. The regression lines have been plotted for the mean row and individual deficits. The lines show the inverse relationship between wind speed and energy deficits. The correlation coefficient between wind speed and mean row deficits is $\mathbf{- 0 . 9 2}$. Thus, wind speed variation alone explains $85 \%$ of the variation in the deficits. The remaining $15 \%$ of the variation in the deficits may be due to factors such as turbulence intensity, spacing between rows, stability, terrain, and diurnal effects. On Figure 4-1, the mean row deficit Iine crosses the zero 1 ine at about $37 \mathrm{mph}$; i.e., there are negligible deficits above this speed. The Nordtank turbine reaches rated output at this speed. The slope of this line is -0.82 . Mean row deficits range from $19 \%$ at $15 \mathrm{mph}$ down to $0 \%$ at $37 \mathrm{mph}$. The regression 1 ine for the maximum individual turbine deficit is steeper than the mean row deficit. The slope of this line is -1.15 and the correlation coefficient between wind speed and turbine deficits is also -0.92 .

The mean row deficits have also been correlated to the thrust coefficient (Ct) and the system coefficient of power ( $\mathrm{Cp}$ ). Recall that $\mathrm{Ct}$ and wind speed have a near-perfect inverse correlation for the Nordtank turbine. The correlation between energy deficits and wind speed is essentially the same in magnitude as the correlation between energy deficits and Ct. On1y the sign is changed, as the correlation coefficients are -0.92 and +0.91 , respectively. The best correlation was between the energy deficits and $\mathrm{Cp}_{\mathrm{p}} \mathbf{0 . 9 4}$. These three parameters -- wind speed, $\mathrm{Cp}$, and $\mathrm{Ct}$-- are not independent variables. They are interrelated, and the wake deficits are a function of a combination of wind speed and turbine performance.

Figures 4-2 and 4-3 are plots of the mean row energy deficits versus $C p$ and Ct. The figures show the regression lines as well as the data points. The correlation coefficients are plotted in the lower left-hand corner of the figures.

There was considerable variation in energy deficits within the test row in each test. The driving factors believed to cause the variability within rows were (1) expected wake trajectory based on wind direction and (2) terrain speed-up effects. Turbines at the end of rows were often at the edge of the expected wake, based on measured wind direction, and these turbines usually had small or negligible deficits, and on a few occasions energy enhancement. 


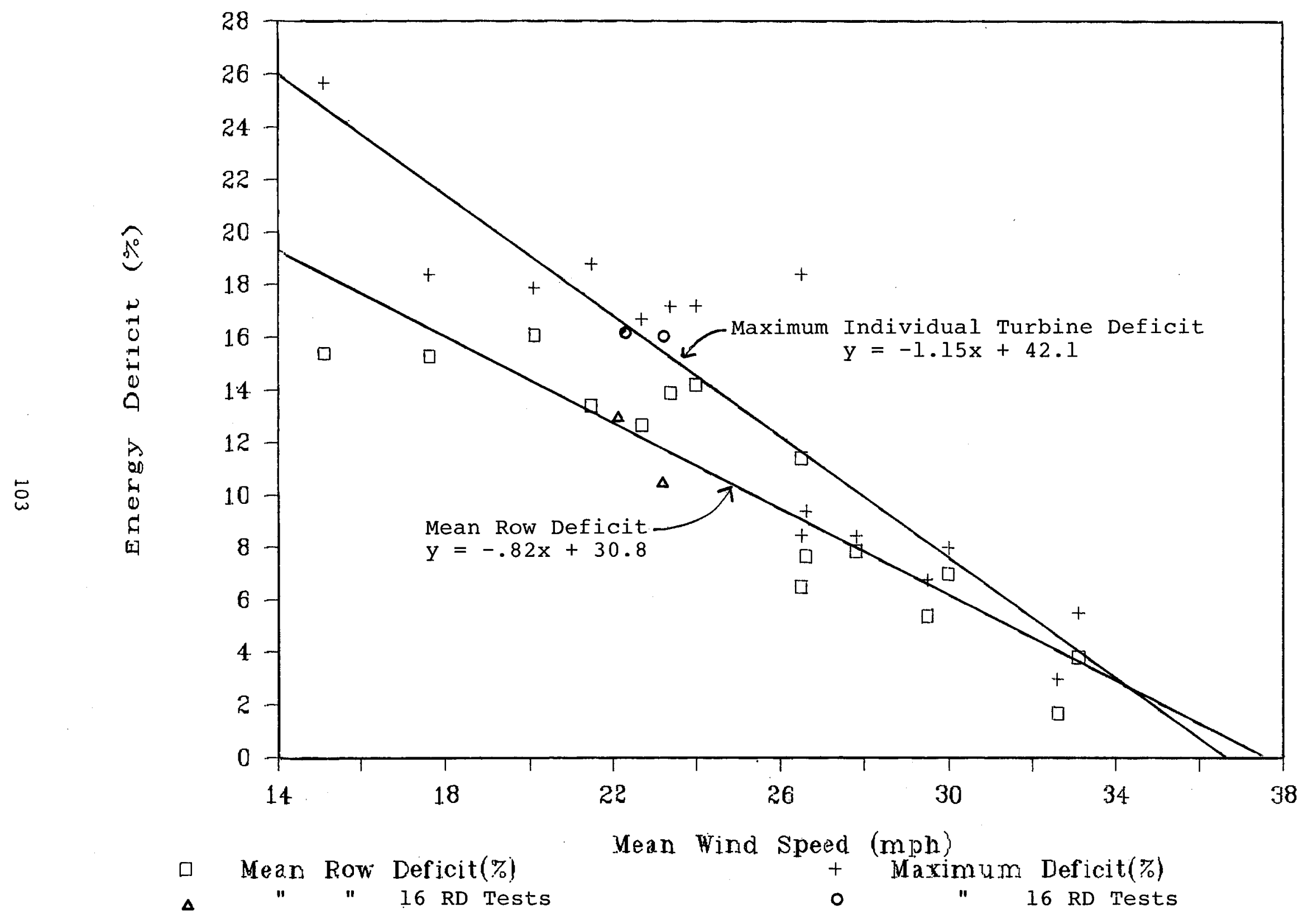

Figure 4-1. Wake Deficits ( $(x)$ vs. Mean Wind Speed 


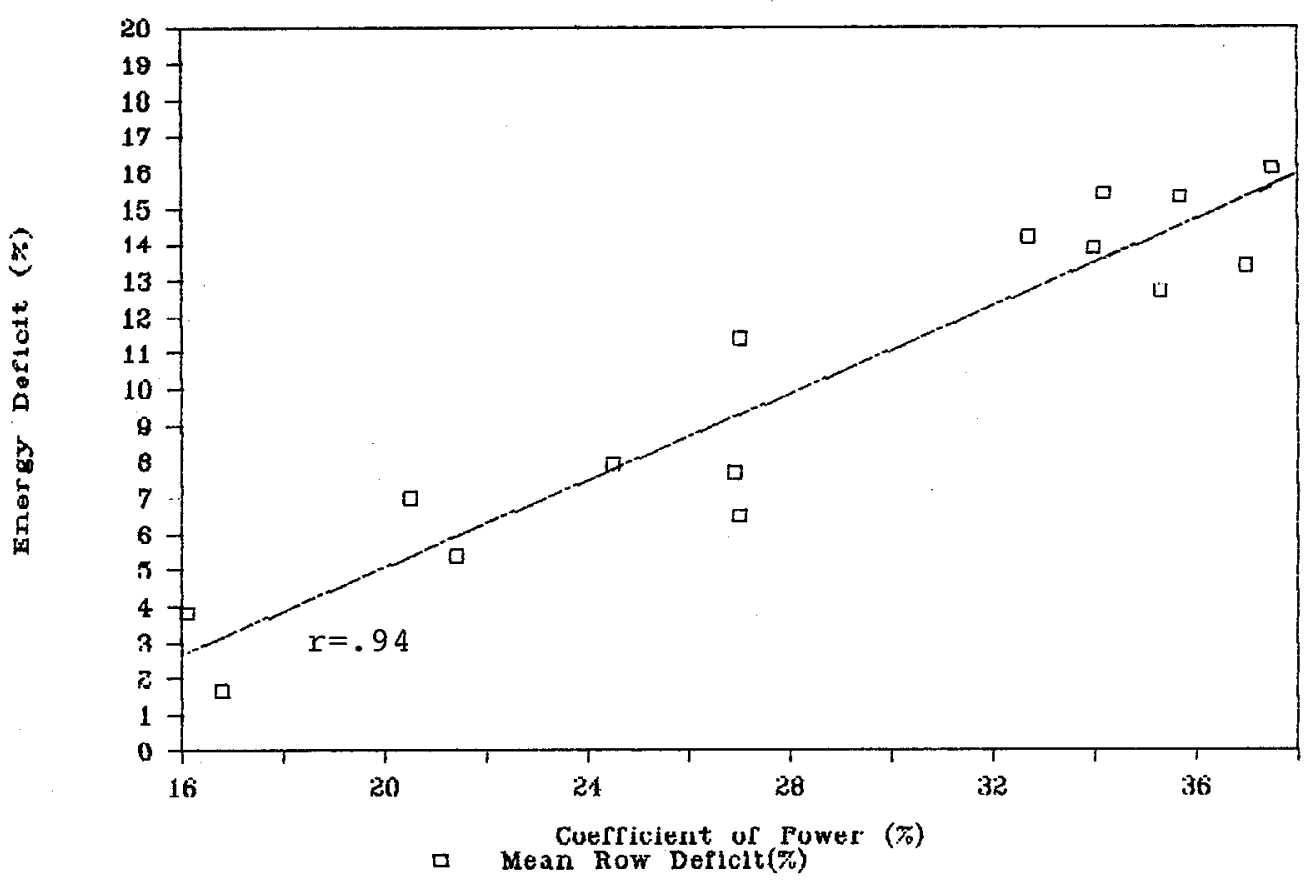

Figure 4-2. Wake Deficits (z) vs. Coefficient of Power ( $(z)$

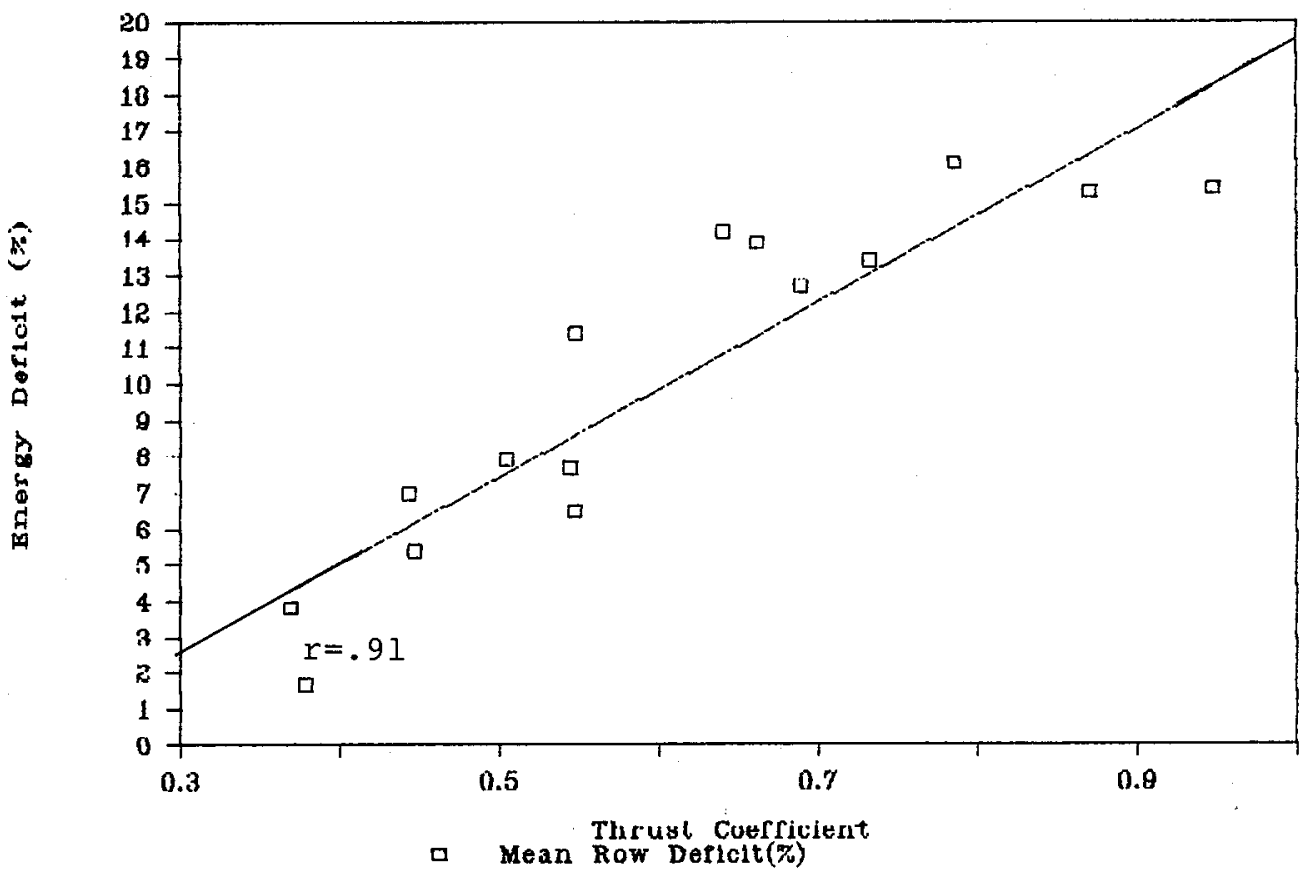

Figure 4-3. Wake Deficits ( $(x)$ vs. Thrust Coefficient 
Terrain enhances or diminishes ambient flow conditions. Turbines at lower elevation sites within a row had lower energy production and higher energy deficits. Thus terrain effects can significantly compound or decrease wake deficits, because of the inverse relationship between wind speed and wake deficits. This is an important finding for siting wind turbines because a terrain-related $10 \mathrm{w}$ wind resource site is likely to experience more deficits than high wind sites. No attempt was made to try to normalize the terrain effects on wake deficits.

Two tests were conducted to measure the effects of a single row of turbines with an upwind spacing of $16 \mathrm{D}$ (double the normal spacing in these arrays). The mean row energy deficit was $12.1 \%$, about the same as in the 8 D tests. This is rather remarkable, as one would have expected lower deficits at greater distances. The stable flow conditions and generally shallow flux layer that characterize the Altamont Pass winds may be responsible for these persistent deficits. The shallow flux layer is typically only about $500 \pm 300 \mathrm{ft}$ thick in the Altamont. The top of this layer is marked by the top of the West Coast subsidence inversion. There is usually 1ittle wind energy above the top of this inversion. The deficits from these $16 \mathrm{D}$ tests are also plotted on Figure 4-1. The figure shows that these data points lie near the regression line of the 8 D tests. Regression analysis of the $16 \mathrm{D}$ deficits suggests that these deficits are more sensitive to changes in speed than the 8 D deficits. The slope of the $16 \mathrm{D}$ regression line (not plotted) is considerably steeper than the $8 \mathrm{D}$ slope. The analysis also suggests that deficits would be negligible in winds speeds above $31 \mathrm{mph}$.

Two array wake effect tests were conducted to determine the effects of two rows of turbines on a downwind row. In the first test, with relatively low wind speeds, the mean energy deficit was $25 \%$, which is considerably higher than the single row tests. However, the results from the second test were quite different. The wind speeds were about $10 \mathrm{mph}$ higher during this test, and the mean energy deficit was only $6 \%$. The inverse relationship between wind speed and energy deficits was more pronounced in this type of test. Linear regression showed that the slope of the regression line was twice as steep for the two-row tests as for the one-row tests. Thus a given change in wind speed produced twice as large a change in energy deficits in the two-row tests.

Three multiple-row tests were conducted to determine the incremental energy deficits of one versus two and one versus three rows of upwind turbines. The wake effects of the first row were similar to other single row tests. The incremental wake energy deficits of the additional rows were on the order of $50 \%$ of the single row deficit in winds below $30 \mathrm{mph}$. In winds above $30 \mathrm{mph}$, the incremental wake deficit from the additional rows was negligible. These results are consistent with the findings of the 16 D tests; in winds above $31 \mathrm{mph}$, the deficits were not discernible.

One test was conducted to measure lateral induction or the "windwall" effect. No discernable effect was measured, possibly because the spacing between turbines was too wide.

Wind speed data were available from every other turbine in the test rows. The wind speed data were collected at $35 \mathrm{ft}$ agl, which is almost exactly half of turbine hub-height of $72 \mathrm{ft}$. In the tests described above, the speed deficits 
were typically $1 \%$ to $5 \%$. Power density $\left(\mathrm{W} / \mathrm{m}^{2}\right)$ deficits were calculated from the wind speed data. These were usually smaller than the energy deficits. The speed and power density deficits are thought to be smaller than the energy deficits because the sensor height was $35 \mathrm{ft}$. It is possible that the wake deficit had not spread much in the vertical and so the anemometer was below the wake. Ideally, wind speed deficits should be measured at hub-height or over the entire rotor disk.

Energy production data collected during periods when the winds blew parallel to the turbine row axis were analyzed. In this situation, spacing between turbines was $1.9 \mathrm{D}$. Two entire winters, the season when these conditions are most likely to occur, were analyzed. Energy production from turbines in each row was compared to that of the lead (upwind) turbine in each row. The energy ratios ranged from about $40 \%$ to $70 \%$, with an overall average of about $50 \%$. From this, we can conclude that the energy deficit was also about $50 \%$ for parallel winds. For winds blowing $22 \frac{1}{2}{ }^{\circ}$ off axis, the mean deficit was $33 \%$. The data were also stratified by wind speed and time of day. The deficits decreased as wind speeds increased. The deficits were higher at night, presumably because of a combination of higher atmospheric stability and lower winds. 


\section{SECTION 5.0 BIBLIOGRAPHY}

E11iott, D. L., J. W. Buck, and J. C. Barnard. 1988. An Examination of Wake Effects and Power Production for a Group of Large Wind Turbines. PNL-6528, Richland, WA: Pacific Northwest Laboratory.

Nierenberg, R. 1987. External Wake Effects. (Unpublished internal report), Lafayette, CA: Howden Wind Parks, Inc.

Nierenberg, R. 1988. Free-Flow Variability on the Jess and Souza Ranches, Altamont Pass. Golden, CO: Solar Energy Research Institute.

Simon, R. 1986. Wind Farm Array Wake Effects for a Micon 60/13 Cluster. San Ramon, CA: Pacific Gas and Electric Company. 


\section{APPENDIX A}

\section{NORTHWEST OR PARALLEL CASE DATA ANALYSES}

The tables 1 isted in this appendix contain the following information:

1) Screening parameters such as speed, direction, or time of day

2) Turbines analyzed

3) Correlation coefficient to upwind turbine

4) 10-min mean energy output at each turbine

5) Energy ratio to upwind turbine

6) Sample size

7) Turbine availability (1isted on the first table of each set only)

The tables are sorted by:

1) Year (ascending order)

2) Ranch (Souza followed by Jess)

3) Turbine strings (alphabetical order)

4) Stratification type
a) wind direction ( 3 tables)
b) wind speed ( 3 tables)
c) time of day (2 tables)

Tables 3-7.1a through 3-7.1r contain the 1986-87 Souza Ranch data. Tables 3-7.2a through 3-7.2nn contain the 1987-88 Souza Ranch data. Tables 3-7.3a through 3-7.3n contain the 1987-88 Jess Ranch data. 
Table 3-7.la Souza E6 row, parallel winds

WINDFARM CORRELATION REPORT

REPORT INTERVAL: WINTER 86-87 Correlation Variable: ENERGY Reference Turbine: $\quad$ E06

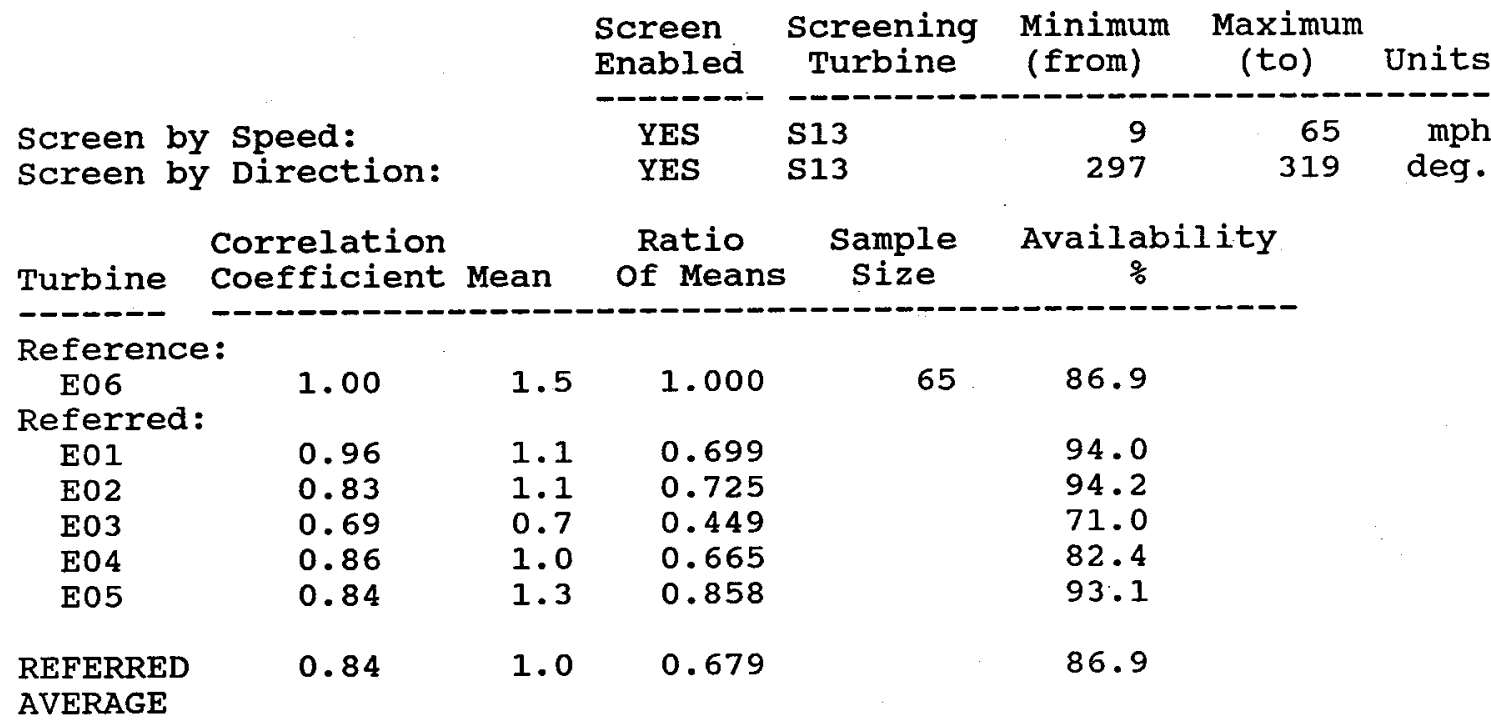

Table 3-7.1b Souza E6 row, -22 degrees

\begin{tabular}{lrrrr}
$\begin{array}{c}\text { Screen } \\
\text { Enabled }\end{array}$ & $\begin{array}{c}\text { Screening } \\
\text { Turbine }\end{array}$ & $\begin{array}{c}\text { Minimum } \\
\text { (from) }\end{array}$ & $\begin{array}{c}\text { Maximum } \\
\text { (to) }\end{array}$ & Units \\
\hline YES & S13 & 9 & 65 & mph \\
YES & S13 & 275 & 297 & deg.
\end{tabular}

Screen by speed:

Screen by Direction:

Ratio Sample

$\begin{array}{lccr}\text { Turbine } \begin{array}{l}\text { Correlation } \\ \text { Coefficient Mean }\end{array} & \begin{array}{c}\text { Ratio } \\ \text { of Means }\end{array} \\ \text { Reference: } & & & \\ \text { E06 } & 1.00 & 0.9 & 1.000 \\ \text { Referred: } & & & \\ \text { E01 } & 0.78 & 0.7 & 0.788 \\ \text { E02 } & 0.86 & 0.8 & 0.920 \\ \text { E03 } & 0.60 & 0.6 & 0.652 \\ \text { E04 } & 0.67 & 0.7 & 0.866 \\ \text { E05 } & 0.85 & 0.9 & 1.076 \\ & & & \\ \text { REFERRED } & 0.73 & 0.7 & 0.806 \\ \text { AVERAGE } & & & \end{array}$


Table 3-7.1c Souza E6 row, +22 degrees

WINDFARM CORRELATION REPORT

REPORT INTERVAL: WINTER 86-87 Correlation Variable: ENERGY

Reference Turbine: $\quad$ E06

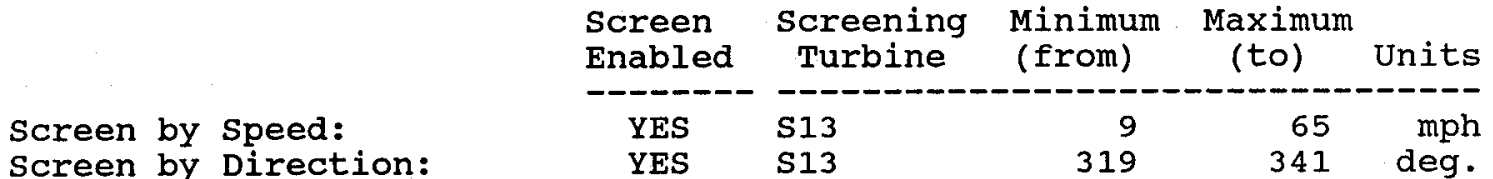

Ratio Sample

Turbine $\begin{array}{lcr}\text { Correlation } & \text { Ratio } & \text { Sample } \\ \text { Coeficient Mean of Means } & \text { Size }\end{array}$

$\begin{array}{lllll}\text { Reference: } & & & & \\ \quad \text { E06 } & 1.00 & 1.6 & 1.000 & 400 \\ \text { Referred: } & & & & \\ \quad \text { E01 } & 0.71 & 0.9 & 0.567 & \\ \text { E02 } & 0.73 & 2.3 & 1.477 \\ \text { E03 } & 0.56 & 1.4 & 0.873 \\ \text { E04 } & 0.67 & 1.5 & 0.979 \\ \text { E05 } & 0.47 & 1.3 & 0.834 \\ \text { REFERRED } & 0.67 & 1.5 & 0.974 & \\ \text { AVERAGE } & & & \end{array}$

Table 3-7.1d Souza E6 row, low winds

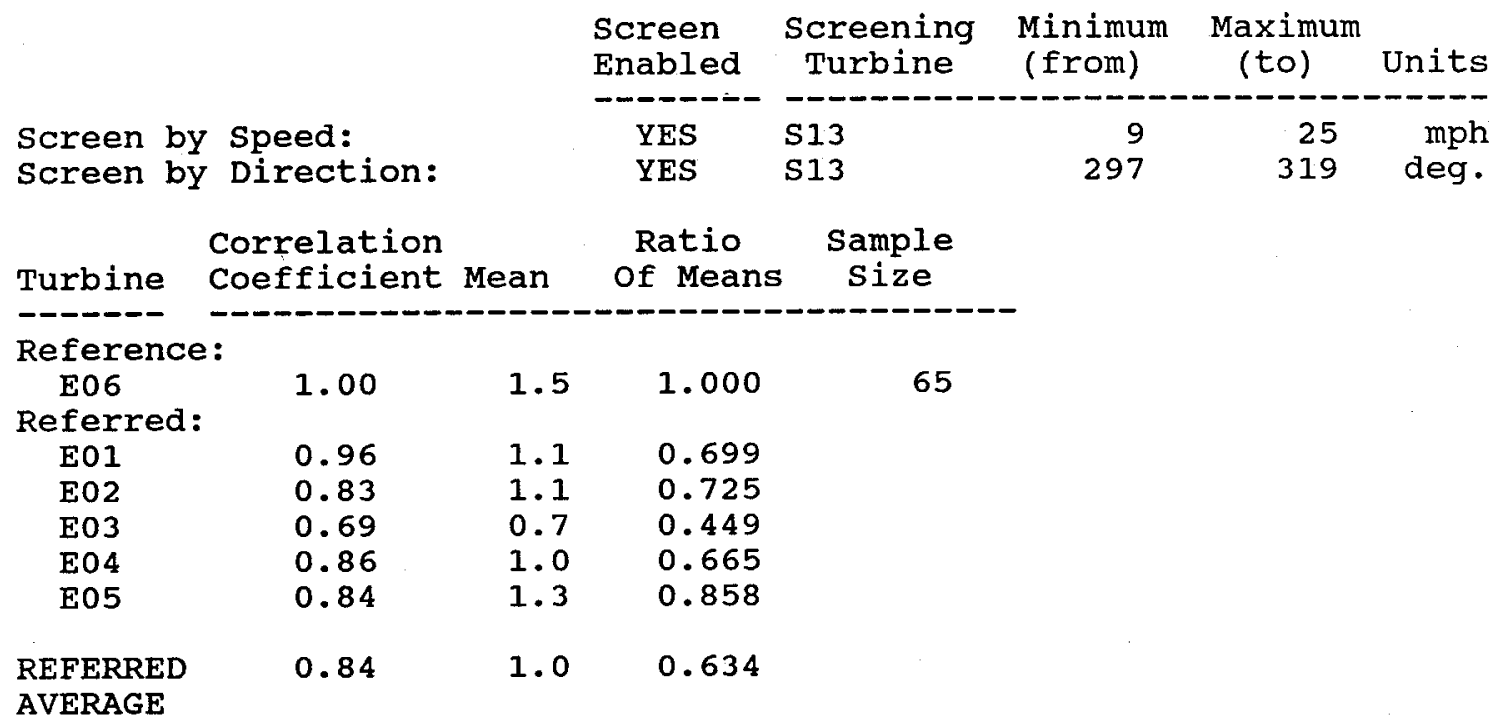


Table 3-7.le Souza E6 row, daylight hours

WINDFARM CORRELATION REPORT

REPORT INTERVAL: WINTER 86-87 Correlation Variable: ENERGY Reference Turbine: $\quad$ E06

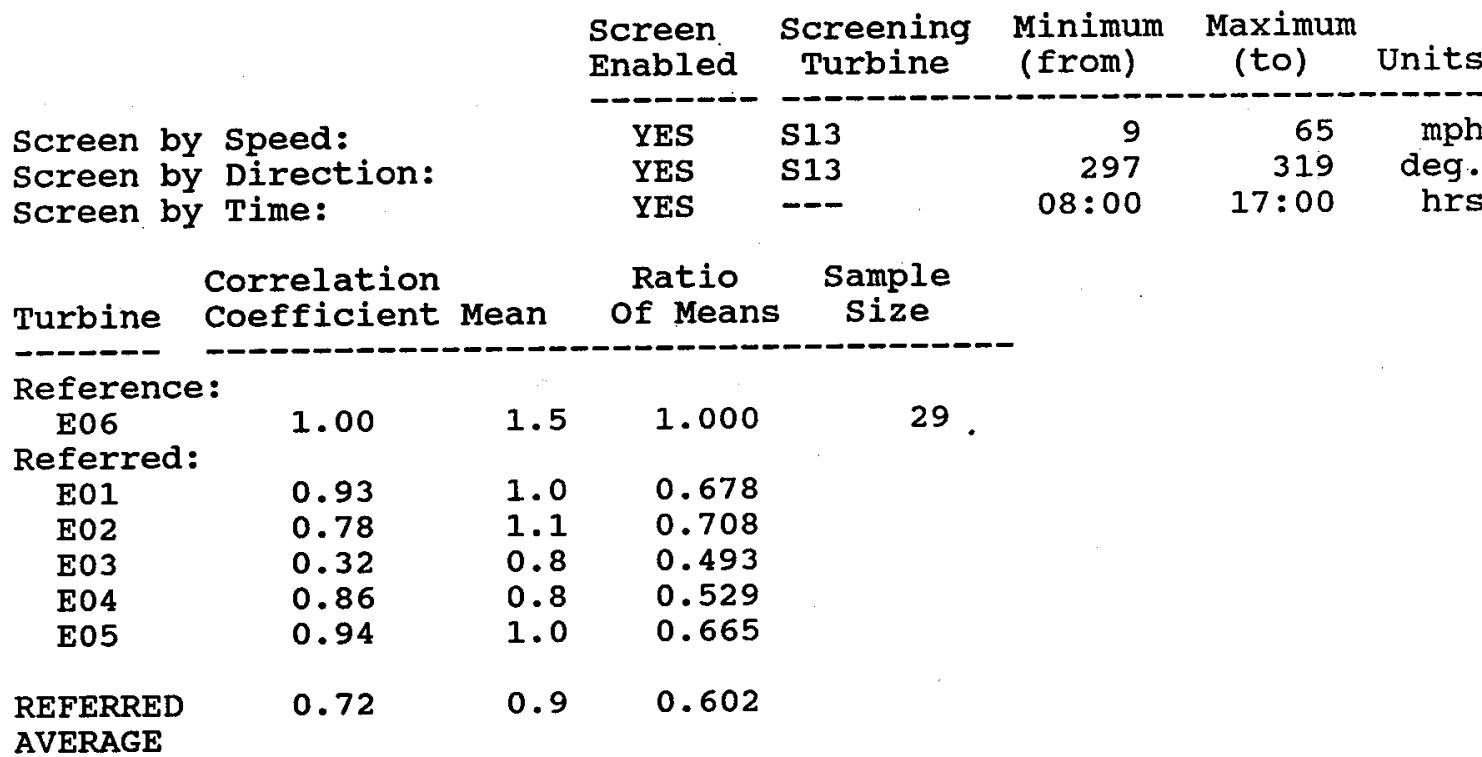

Table 3-7.1f Souza E6 row, nightime hours

\begin{tabular}{lrrrr}
$\begin{array}{l}\text { Screen } \\
\text { Enabled }\end{array}$ & $\begin{array}{c}\text { Screening } \\
\text { Turbine }\end{array}$ & $\begin{array}{c}\text { Minimum } \\
\text { (from) }\end{array}$ & $\begin{array}{c}\text { Maximum } \\
\text { (to) }\end{array}$ & Units \\
\hline-- & -- & 9 & 65 & mph \\
YES & S13 & 297 & 319 & deg. \\
YES & S13 & $19: 00$ & $05: 00$ & hrs
\end{tabular}

Screen by Direction:

YES ---

$19: 00$

$\begin{array}{ccc}\text { Correlation } & \text { Ratio Sample } & \text { Sarbine coefficient Mean of Means } \\ \text { Size }\end{array}$

\begin{tabular}{|c|c|c|c|c|}
\hline \multicolumn{5}{|l|}{ Reference: } \\
\hline $\begin{array}{c}\text { E06 } \\
\text { Referred: }\end{array}$ & 1.00 & 0.4 & 1.000 & 16 \\
\hline E01 & 0.76 & 0.3 & 0.592 & \\
\hline E02 & 0.48 & 0.5 & 1.194 & \\
\hline $\mathrm{EO} 3$ & 0.23 & 0.2 & 0.550 & \\
\hline E04 & -0.19 & 0.5 & 1.265 & \\
\hline E05 & 0.02 & 1.0 & 2.223 & \\
\hline REFERRED & 0.32 & 0.4 & 0.900 & \\
\hline
\end{tabular}


Table 3-7.lg Souza El0 row, parallel winds

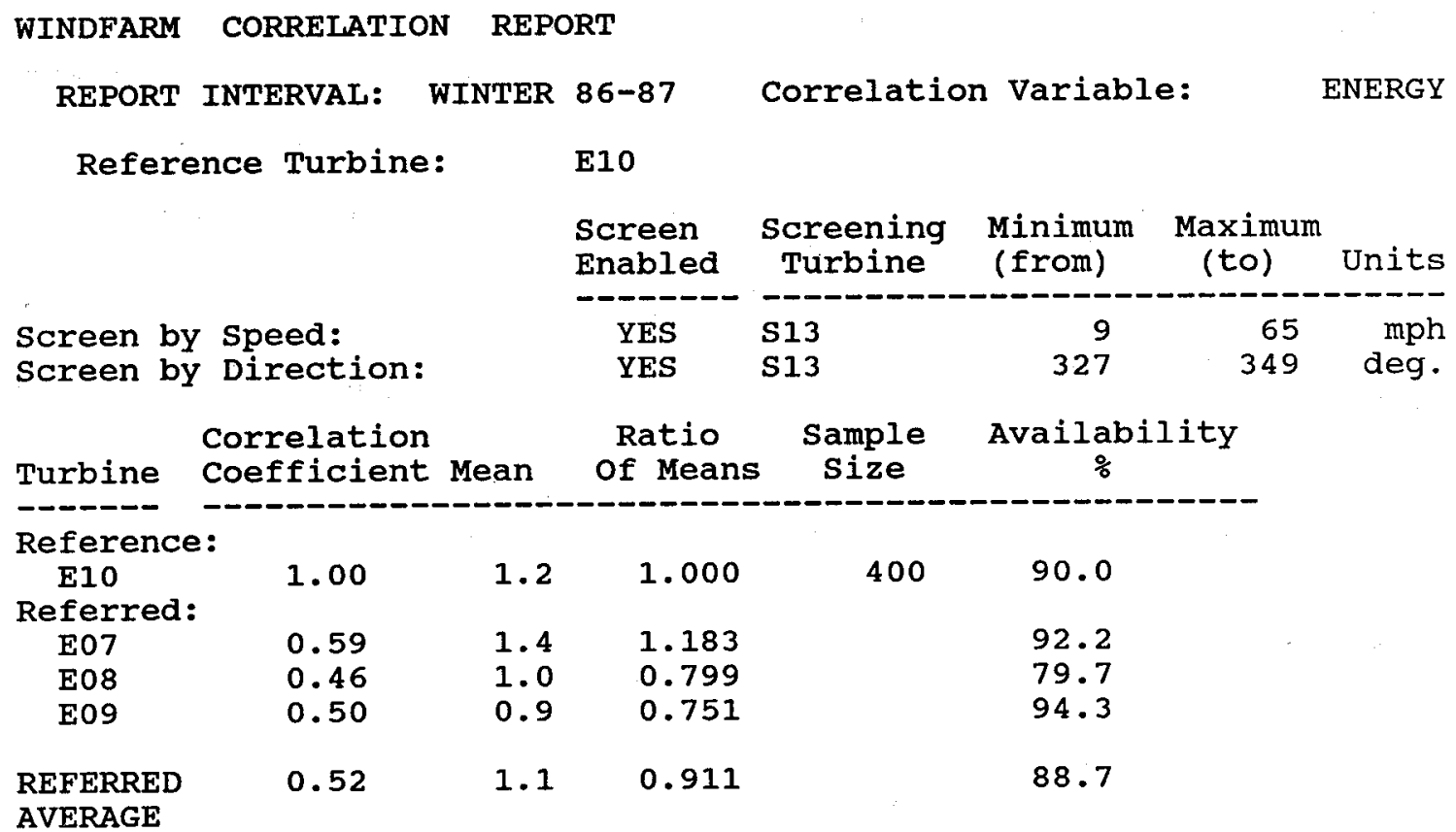

Table 3-7.1h Souza Elo row, -22 degrees

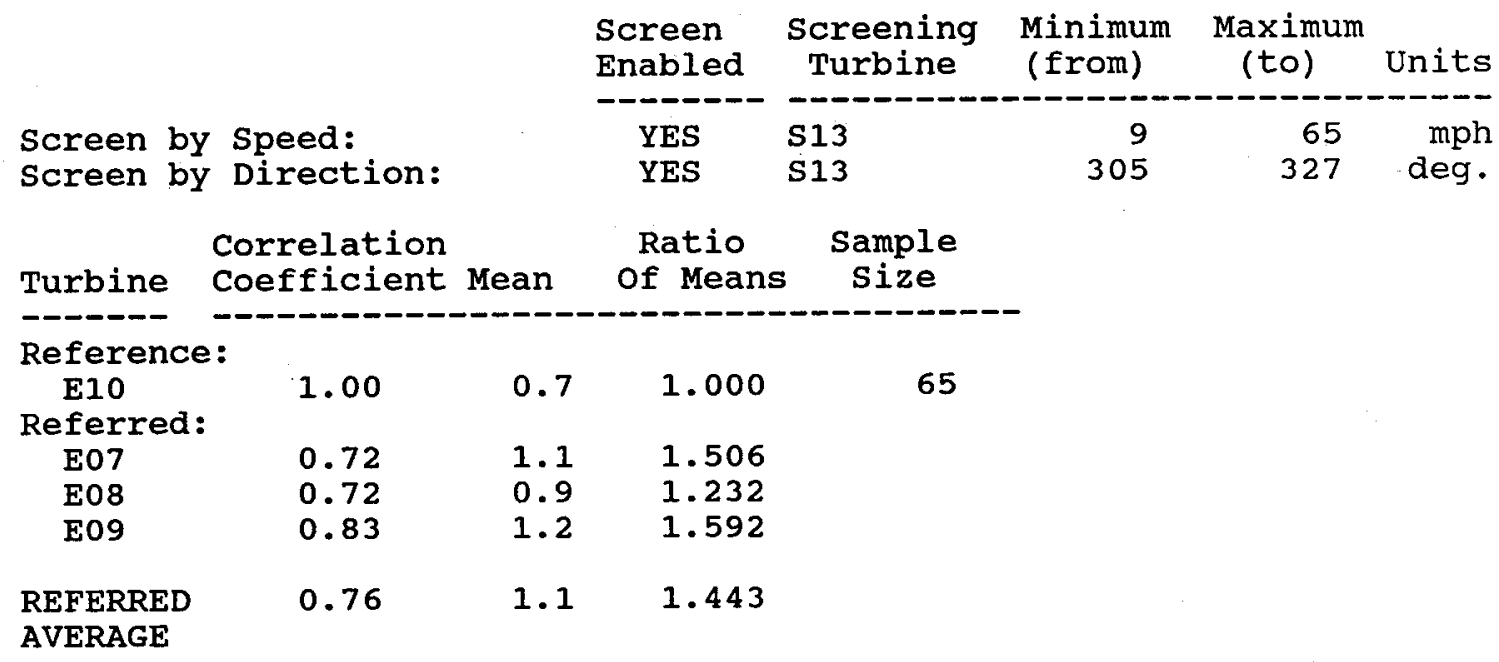


Table 3-7.1i Souza El0 row, +22 degrees

\begin{tabular}{|c|c|c|c|c|c|c|c|}
\hline \multirow{2}{*}{$\begin{array}{l}\text { WINDFARM } \\
\text { REPORT }\end{array}$} & CORRELATION & \multicolumn{2}{|c|}{ REPORT } & \multirow[b]{2}{*}{ Correlation } & \multirow[b]{2}{*}{ Variable } & & \multirow[b]{2}{*}{ ENERGY } \\
\hline & INTERVAL: & WINTER & \multirow{2}{*}{$\begin{array}{l}86-87 \\
\text { E10 }\end{array}$} & & & & \\
\hline Refere & ence Turbin & & & \multirow[b]{2}{*}{$\begin{array}{l}\text { Screening } \\
\text { Turbine }\end{array}$} & \multirow[b]{2}{*}{$\begin{array}{l}\text { Minimum } \\
\text { (from) }\end{array}$} & \multirow[b]{2}{*}{$\begin{array}{l}\text { Maximum } \\
\text { (to) }\end{array}$} & \multirow[b]{2}{*}{ Units } \\
\hline & & & $\begin{array}{l}\text { Screen } \\
\text { Enabled }\end{array}$ & & & & \\
\hline $\begin{array}{l}\text { Screen by } \\
\text { screen by }\end{array}$ & $\begin{array}{l}\text { Speed: } \\
\text { Direction }\end{array}$ & & $\begin{array}{l}\text { YES } \\
\text { YES }\end{array}$ & $\begin{array}{l}\text { S13 } \\
\text { S13 }\end{array}$ & $\begin{array}{r}9 \\
349\end{array}$ & $\begin{array}{l}65 \\
11\end{array}$ & $\begin{array}{l}\text { mph } \\
\text { deg. }\end{array}$ \\
\hline Turbine & $\begin{array}{l}\text { Correlatio } \\
\text { Coefficien }\end{array}$ & t Mean & $\begin{array}{l}\text { Ratio } \\
\text { of Means }\end{array}$ & $\begin{array}{l}\text { Sample } \\
\text { Size }\end{array}$ & & & \\
\hline Reference & : & & --ー-ー-ー-ー & & & & \\
\hline $\begin{array}{l}\text { E10 } \\
\text { Referred: }\end{array}$ & 1.00 & 2.8 & 1.000 & 519 & & & \\
\hline $\begin{array}{l}\text { E07 } \\
\text { E08 } \\
\text { E09 }\end{array}$ & $\begin{array}{l}0.86 \\
0.77 \\
0.87\end{array}$ & $\begin{array}{l}1.5 \\
0.9 \\
1.2\end{array}$ & $\begin{array}{l}0.518 \\
0.320 \\
0.429\end{array}$ & & & & \\
\hline $\begin{array}{l}\text { REFERRED } \\
\text { AVERAGE }\end{array}$ & 0.83 & 1.2 & 0.422 & & & & \\
\hline
\end{tabular}

Table 3-7.1j Souza El0 row, low winds

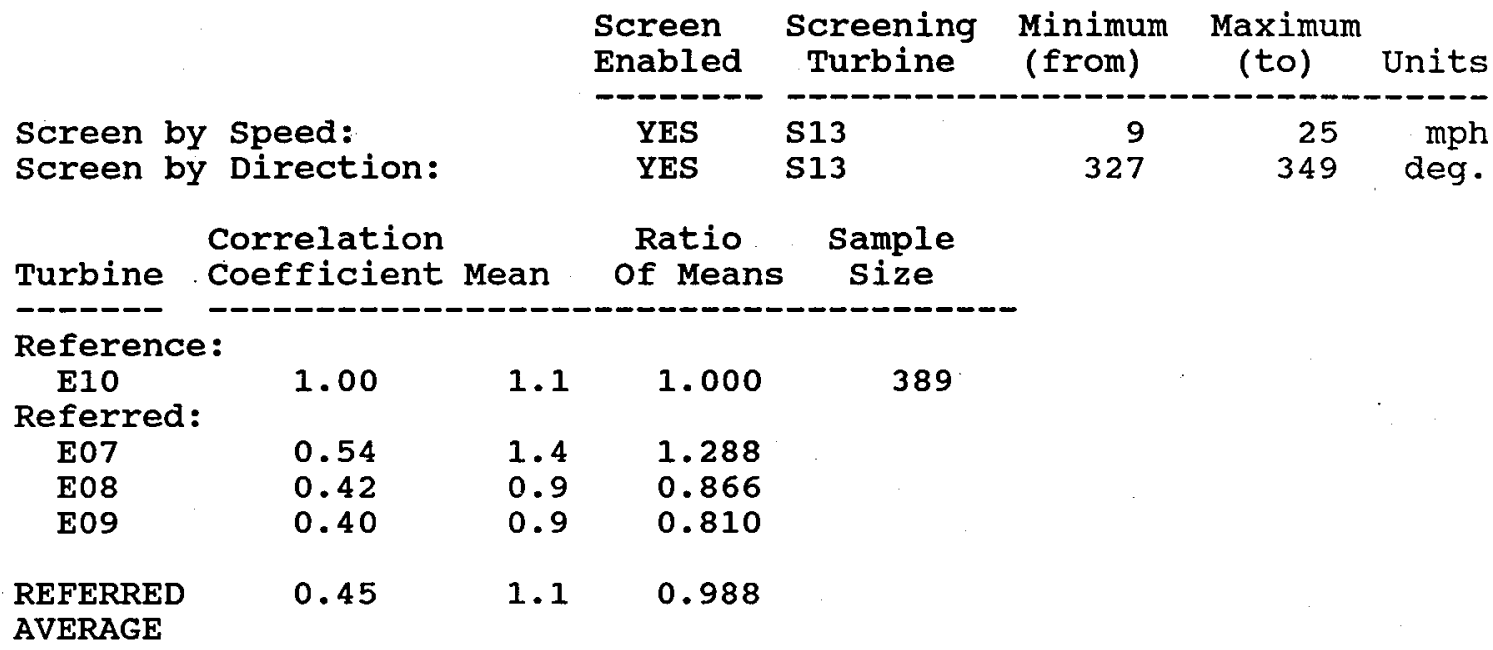


Table 3-7.lk Souza El0 row, moderate winds

WINDFARM CORRELATION REPORT

REPORT INTERVAL: WINTER 86-87 Correlation Variable: ENERGY

Reference Turbine: E10

\begin{tabular}{|c|c|c|c|c|c|c|c|}
\hline & & & $\begin{array}{l}\text { Screen } \\
\text { Enabled }\end{array}$ & $\begin{array}{l}\text { Screening } \\
\text { Turbine }\end{array}$ & $\begin{array}{l}\text { Minimum } \\
\text { (from) }\end{array}$ & $\begin{array}{l}\text { Maximum } \\
\text { (to) }\end{array}$ & Units \\
\hline $\begin{array}{l}\text { Screen by } \\
\text { Screen by }\end{array}$ & $\begin{array}{l}\text { Speed: } \\
\text { Direction: }\end{array}$ & & $\begin{array}{l}\text { YES } \\
\text { YES }\end{array}$ & $\begin{array}{l}\text { S13 } \\
\text { S13 }\end{array}$ & $\begin{array}{r}15 \\
327\end{array}$ & $\begin{array}{r}65 \\
349\end{array}$ & $\begin{array}{l}\text { mph } \\
\text { deg. }\end{array}$ \\
\hline Turbine & $\begin{array}{l}\text { Correlation } \\
\text { Coefficient }\end{array}$ & Mean & $\begin{array}{l}\text { Ratio } \\
\text { of Means }\end{array}$ & $\begin{array}{l}\text { Sample } \\
\text { Size }\end{array}$ & & & \\
\hline $\begin{array}{l}\text { Reference } \\
\text { E10 } \\
\text { Referred: }\end{array}$ & 1.00 & 2.5 & 1.000 & 159 & & & \\
\hline $\begin{array}{l}\text { E07 } \\
\text { E08 } \\
\text { E09 }\end{array}$ & $\begin{array}{l}0.45 \\
0.29 \\
0.47\end{array}$ & $\begin{array}{l}2.0 \\
1.4 \\
1.1\end{array}$ & $\begin{array}{l}0.807 \\
0.560 \\
0.465\end{array}$ & & & & \\
\hline $\begin{array}{l}\text { REFERRED } \\
\text { AVERAGE }\end{array}$ & 0.40 & 1.5 & 0.611 & & & & \\
\hline
\end{tabular}

Table 3-7.1l Souza, Elo row, high winds

\begin{tabular}{|c|c|c|c|c|c|c|c|}
\hline & & & $\begin{array}{l}\text { Screen } \\
\text { Enabled }\end{array}$ & $\begin{array}{l}\text { Screening } \\
\text { Turbine }\end{array}$ & $\begin{array}{l}\text { Minimum } \\
\text { (from) }\end{array}$ & $\begin{array}{l}\text { Maximum } \\
(\text { to })\end{array}$ & Units \\
\hline $\begin{array}{l}\text { Screen by } \\
\text { Screen by }\end{array}$ & $\begin{array}{l}\text { Speed: } \\
\text { Direction: }\end{array}$ & & $\begin{array}{l}\text { YES } \\
\text { YES }\end{array}$ & $\begin{array}{l}\mathrm{S} 13 \\
\mathrm{~S} 13\end{array}$ & $\begin{array}{r}20 \\
327\end{array}$ & $\begin{array}{r}65 \\
349\end{array}$ & $\begin{array}{l}\text { mph } \\
\text { deg. }\end{array}$ \\
\hline Turbine & $\begin{array}{l}\text { Correlation } \\
\text { Coefficient }\end{array}$ & Mean & $\begin{array}{l}\text { Ratio } \\
\text { of Means }\end{array}$ & $\begin{array}{l}\text { Sample } \\
\text { Size }\end{array}$ & & & \\
\hline $\begin{array}{l}\text { Reference } \\
\text { E10 }\end{array}$ & 1.00 & 4.1 & 1.000 & 54 & & & \\
\hline $\begin{array}{l}\text { Referred: } \\
\text { E07 } \\
\text { E08 } \\
\text { E09 }\end{array}$ & $\begin{array}{l}0.48 \\
0.33 \\
0.64\end{array}$ & $\begin{array}{l}2.5 \\
1.8 \\
1.5\end{array}$ & $\begin{array}{l}0.609 \\
0.434 \\
0.367\end{array}$ & & & & \\
\hline $\begin{array}{l}\text { REFERRED } \\
\text { AVERAGE }\end{array}$ & 0.48 & 1.9 & 0.470 & & & & \\
\hline
\end{tabular}


Table 3-7.1m Souza El0 row, daylight hours

\section{WINDFARM CORRELATION REPORT}

REPORT INTERVAL: WINTER 86-87 Correlation. Variable: ENERGY

Reference Turbine: $\quad$ E10

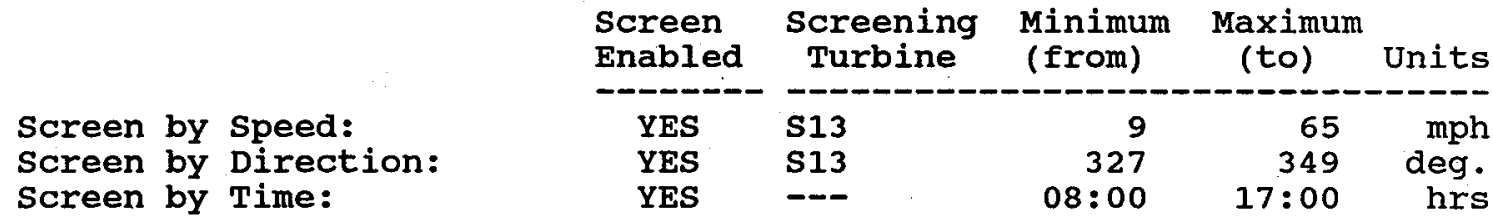

$\begin{array}{lll} & \text { Correlation } & \text { Ratio Sample } \\ \text { Turbine } & \text { Coefficient Mean of Means Size }\end{array}$

Reference:

E10 $1.00 \quad 1.3 \quad 1.000 \quad 97$.

Referred:

E07

0.66

1.4

1.103

E08

0.59

1.0

0.804

E09

0.60

1.1

0.904

REFERRED

0.62

1.2

0.937

AVERAGE

Table 3-7.In Souza El0 row, nightime hours

Screen by speed:

Screen by Direction:

Screen by Time:

\begin{tabular}{lrrrr}
$\begin{array}{l}\text { Screen } \\
\text { Enabled }\end{array}$ & $\begin{array}{c}\text { Screening } \\
\text { Turbine }\end{array}$ & $\begin{array}{c}\text { Minimum } \\
\text { (from) }\end{array}$ & $\begin{array}{c}\text { Maximum } \\
\text { (to) }\end{array}$ & Units \\
\hline YES & S13 & 9 & 65 & mph \\
YES & S13 & 327 & 349 & deg. \\
YES & --- & $19: 00$ & $05: 00$ & hrs
\end{tabular}

\begin{tabular}{lcccc} 
Turbine & $\begin{array}{l}\text { Correlation } \\
\text { Coefficient Mean }\end{array}$ & $\begin{array}{c}\text { Ratio } \\
\text { of Means }\end{array}$ & $\begin{array}{c}\text { Sample } \\
\text { Size }\end{array}$ \\
\hline $\begin{array}{l}\text { Reference: } \\
\text { E10 }\end{array}$ & 1.00 & 1.3 & 1.000 & 225 \\
$\begin{array}{l}\text { Referred: } \\
\text { E07 }\end{array}$ & 0.59 & 1.4 & 1.146 & \\
E08 & 0.36 & 0.9 & 0.732 & \\
E09 & 0.42 & 0.8 & 0.662 & \\
REFERRED & 0.46 & 1.0 & 0.847 & \\
AVERAGE & & & &
\end{tabular}


Table 3-7.10 Souza F10 row, parallel winds

WINDFARM CORRELATION REPORT

REPORT INTERVAL: WINTER 86-87 Correlation Variable: ENERGY

Reference Turbine: $\quad$ F10

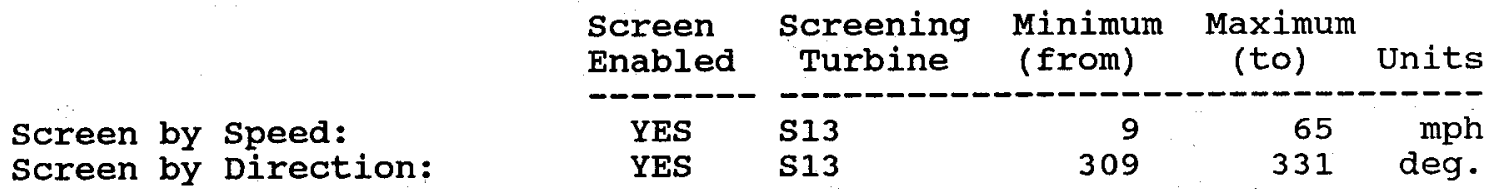

\begin{tabular}{lrrrcc} 
Turbine & $\begin{array}{l}\text { Correlation } \\
\text { Coefficient Mean }\end{array}$ & $\begin{array}{c}\text { Ratio } \\
\text { Of Means }\end{array}$ & $\begin{array}{c}\text { Sample } \\
\text { Size }\end{array}$ & $\begin{array}{c}\text { Availability } \\
\%\end{array}$ \\
\hline $\begin{array}{l}\text { Reference: } \\
\text { F10 }\end{array}$ & 1.00 & 1.6 & 1.000 & 65 & 89.0 \\
Referred: & & & & & 93.5 \\
F05 & 0.69 & 1.7 & 1.052 & 91.1 \\
F06 & 0.91 & 1.3 & 0.815 & 94.0 \\
F07 & 0.89 & 1.7 & 1.067 & 76.9 \\
F09 & -0.06 & 0.3 & 0.161 & 88.9 \\
REFERRED & 0.61 & 1.3 & 0.774 & &
\end{tabular}

AVERAGE

Note: F08 was not included due to low availability.

Table 3-7.lp Souza Fl0 row, -22 degrees

\begin{tabular}{|c|c|c|c|c|c|c|c|}
\hline & & & $\begin{array}{l}\text { Screen } \\
\text { Enabled }\end{array}$ & $\begin{array}{l}\text { Screening } \\
\text { Turbine }\end{array}$ & $\begin{array}{l}\text { Minimum } \\
\text { (from) }\end{array}$ & $\begin{array}{l}\text { Maximum } \\
\text { (to) }\end{array}$ & Units \\
\hline $\begin{array}{l}\text { Screen by } \\
\text { Screen by }\end{array}$ & $\begin{array}{l}\text { Speed: } \\
\text { Direction: }\end{array}$ & & $\begin{array}{l}\text { YES } \\
\text { YES }\end{array}$ & $\begin{array}{l}\text { S13 } \\
\text { S13 }\end{array}$ & $\begin{array}{r}9 \\
287\end{array}$ & $\begin{array}{r}65 \\
309\end{array}$ & $\begin{array}{l}\text { mph } \\
\text { deg. }\end{array}$ \\
\hline Turbine & $\begin{array}{l}\text { Correlation } \\
\text { coefficient }\end{array}$ & Mean & $\begin{array}{l}\text { Ratio } \\
\text { of Means }\end{array}$ & $\begin{array}{c}\text { Sample } \\
\text { Size }\end{array}$ & & & \\
\hline $\begin{array}{l}\text { Reference } \\
\text { F10 } \\
\text { Referred: } \\
\text { F05 } \\
\text { F06 } \\
\text { F07 } \\
\text { F09 }\end{array}$ & $\begin{array}{l}1.00 \\
0.41 \\
0.57 \\
0.56 \\
0.43\end{array}$ & $\begin{array}{l}1.0 \\
1.2 \\
0.9 \\
1.0 \\
0.7\end{array}$ & $\begin{array}{l}1.000 \\
1.255 \\
0.874 \\
0.998 \\
0.666\end{array}$ & 89 & & & \\
\hline $\begin{array}{l}\text { REFERRED } \\
\text { AVERAGE }\end{array}$ & 0.49 & 1.0 & 0.948 & & & & \\
\hline
\end{tabular}


Table 3-7.lq Souza Fl0 row, +22 degrees

WINDFARM CORRELATION REPORT

REPORT INTERVAL: WINTER 86-87 Correlation Variable: ENERGY

Reference Turbine: F10

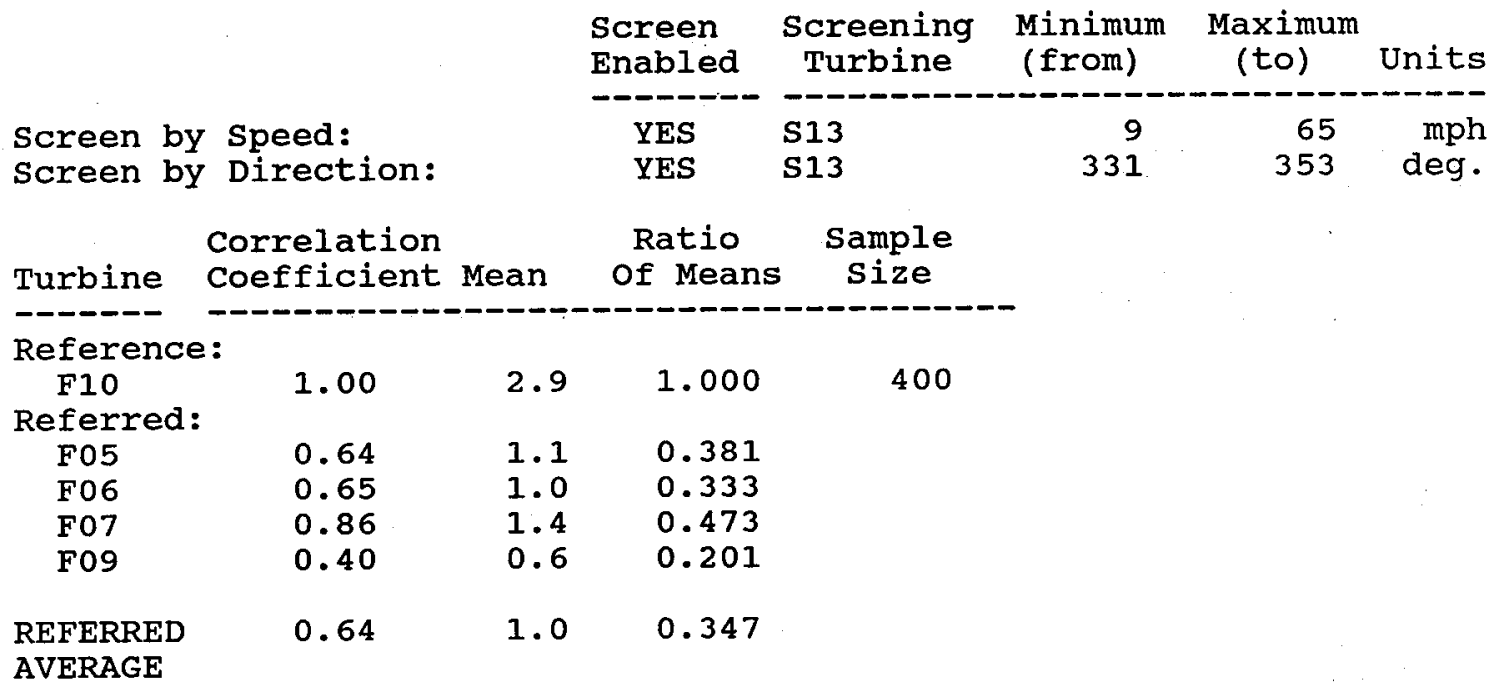

Table 3-7.1r Souza Flo row, low winds

\begin{tabular}{|c|c|c|c|c|c|c|c|}
\hline & & $\ldots$ & $\begin{array}{l}\text { Screen } \\
\text { Enabled }\end{array}$ & $\begin{array}{l}\text { Screening } \\
\text { Turbine }\end{array}$ & $\begin{array}{l}\text { Minimum } \\
\text { (from) }\end{array}$ & $\begin{array}{l}\text { Maximum } \\
(\text { to })\end{array}$ & Units \\
\hline $\begin{array}{l}\text { Screen by } \\
\text { Screen by }\end{array}$ & $\begin{array}{l}\text { Speed: } \\
\text { Direction: }\end{array}$ & & $\begin{array}{l}\text { YES } \\
\text { YES }\end{array}$ & $\begin{array}{l}\text { S13 } \\
\text { S13 }\end{array}$ & $\begin{array}{r}9 \\
309\end{array}$ & $\begin{array}{r}25 \\
331\end{array}$ & $\begin{array}{l}\text { mph } \\
\text { deg. }\end{array}$ \\
\hline Turbine & $\begin{array}{l}\text { Correlation } \\
\text { Coefficient }\end{array}$ & Mean & $\begin{array}{l}\text { Ratio } \\
\text { of Means }\end{array}$ & $\begin{array}{l}\text { Sample } \\
\text { Size }\end{array}$ & & & \\
\hline $\begin{array}{l}\text { Reference: } \\
\text { F10 }\end{array}$ & 1.00 & 1.6 & 1.000 & 65 & & & \\
\hline $\begin{array}{l}\text { Reterred: } \\
\text { F05 } \\
\text { F06 } \\
\text { F07 } \\
\text { F09 }\end{array}$ & $\begin{array}{r}0.69 \\
0.91 \\
0.89 \\
-0.06\end{array}$ & $\begin{array}{l}1.7 \\
1.3 \\
1.7 \\
0.3\end{array}$ & $\begin{array}{l}1.052 \\
0.815 \\
1.067 \\
0.161\end{array}$ & & & & \\
\hline $\begin{array}{l}\text { REFERRED } \\
\text { AVERAGE }\end{array}$ & 0.61 & 1.3 & 0.774 & & & & \\
\hline
\end{tabular}


Table 3-7.2a Souza D6 row, parallel winds

WINDFARM CORRELATION REPORT

REPORT INTERVAL: WINTER 87-88 Correlation Variable: ENERGY

Reference Turbine: D06

\begin{tabular}{|c|c|c|c|c|c|}
\hline & $\begin{array}{l}\text { Screen } \\
\text { Enabled }\end{array}$ & $\begin{array}{l}\text { Screening } \\
\text { Turbine }\end{array}$ & $\begin{array}{l}\text { Minimum } \\
\text { (from) }\end{array}$ & $\begin{array}{l}\text { Maximum } \\
\text { (to) }\end{array}$ & Units \\
\hline $\begin{array}{l}\text { Screen by Speed: } \\
\text { Screen by Direction: }\end{array}$ & $\begin{array}{l}\text { YES } \\
\text { YES }\end{array}$ & $\begin{array}{l}\mathrm{S} 13 \\
\mathrm{~S} 13\end{array}$ & $\begin{array}{r}9 \\
315\end{array}$ & $\begin{array}{r}65 \\
337\end{array}$ & $\begin{array}{l}\text { mph } \\
\text { deg. }\end{array}$ \\
\hline
\end{tabular}

Ratio: Sample Availability

\begin{tabular}{lccccr} 
Turbine & $\begin{array}{l}\text { Correlation } \\
\text { Coefficient }\end{array}$ & Mean & $\begin{array}{c}\text { Ratio } \\
\text { of Means }\end{array}$ & $\begin{array}{c}\text { Sample } \\
\text { Size }\end{array}$ & $\begin{array}{r}\text { Availabil } \\
\%\end{array}$ \\
\hline $\begin{array}{l}\text { Reference: } \\
\text { D06 }\end{array}$ & 1.00 & 4.7 & 1.000 & 1614 & 91.8 \\
$\begin{array}{l}\text { Referred: } \\
\text { D01 }\end{array}$ & 0.40 & 1.0 & 0.214 & & 64.7 \\
D02 & 0.88 & 2.6 & 0.557 & 87.3 \\
D03 & 0.58 & 2.7 & 0.583 & 59.9 \\
D04 & 0.63 & 2.5 & 0.530 & 62.2 \\
REFERRED & 0.62 & 2.2 & 0.471 & & 68.5 \\
AVERAGE & & & & &
\end{tabular}

Note: D05 was not included due to low availability.

Screen by Direction:
Screen by speed:

Table 3-7.2b Souza D6 row, -22 degrees

\begin{tabular}{lrrrr}
$\begin{array}{c}\text { Screen } \\
\text { Enabled }\end{array}$ & $\begin{array}{c}\text { Screening } \\
\text { Turbine }\end{array}$ & $\begin{array}{c}\text { Minimum } \\
\text { (from) }\end{array}$ & $\begin{array}{c}\text { Maximum } \\
\text { (to) }\end{array}$ & Units \\
\hline YES & S13 & 9 & 65 & mph \\
YES & S13 & 293 & 315 & deg.
\end{tabular}

$\begin{array}{lccr}\text { Turbine } & \begin{array}{c}\text { Correlation } \\ \text { Coefficient Mean }\end{array} & \begin{array}{l}\text { Ratio } \\ \text { Of Mean }\end{array} \\ \text { Reference: } & & & \\ \text { D06 } & 1.00 & 2.4 & 1.000 \\ \text { Referred: } & & & \\ \text { D01 } & 0.44 & 0.4 & 0.154 \\ \text { D02 } & 0.81 & 1.1 & 0.472 \\ \text { D03 } & 0.60 & 1.3 & 0.514 \\ \text { D04 } & 0.49 & 0.8 & 0.329 \\ & & & \\ \text { REFERRED } & 0.59 & 0.9 & 0.367\end{array}$


Table 3-7.2C Souza D6 row, +22 degrees

WINDFARM CORRETATION REPORT

REPORT INTERVAL: WINTER 87-88 Correlation Variable: ENERGY

Reference Turbine: D06

\begin{tabular}{|c|c|c|c|c|}
\hline & $\begin{array}{l}\text { Screen } \\
\text { Enabled }\end{array}$ & $\begin{array}{l}\text { Screening } \\
\text { Turbine }\end{array}$ & $\begin{array}{l}\text { Minimum } \\
\text { (from) }\end{array}$ & $\begin{array}{l}\text { Maximum } \\
\text { (to) }\end{array}$ \\
\hline $\begin{array}{l}\text { Screen by Speed: } \\
\text { Screen by Direction: }\end{array}$ & $\begin{array}{l}\text { YES } \\
\text { YES }\end{array}$ & $\begin{array}{l}S 13 \\
S 13\end{array}$ & $\begin{array}{r}9 \\
337\end{array}$ & $\begin{array}{r}65 \\
359\end{array}$ \\
\hline
\end{tabular}

\begin{tabular}{lcccc} 
Turbine & $\begin{array}{l}\text { Correlation } \\
\text { Coefficient Mean }\end{array}$ & $\begin{array}{c}\text { Ratio } \\
\text { of Means }\end{array}$ & $\begin{array}{c}\text { Sample } \\
\text { Size }\end{array}$ \\
\hline $\begin{array}{l}\text { Reference: } \\
\text { D06 }\end{array}$ & 1.00 & 6.5 & 1.000 & 398 \\
Referred: & & & & \\
$\quad$ D01 & 0.58 & 3.6 & 0.554 & \\
D02 & 0.92 & 5.0 & 0.769 & \\
D03 & 0.68 & 5.3 & 0.811 & \\
D04 & 0.59 & 4.3 & 0.655 & \\
REFERRED & 0.69 & 4.6 & 0.697 & \\
AVERAGE & & &
\end{tabular}

Table 3-7.2d Souza D6 row, low winds

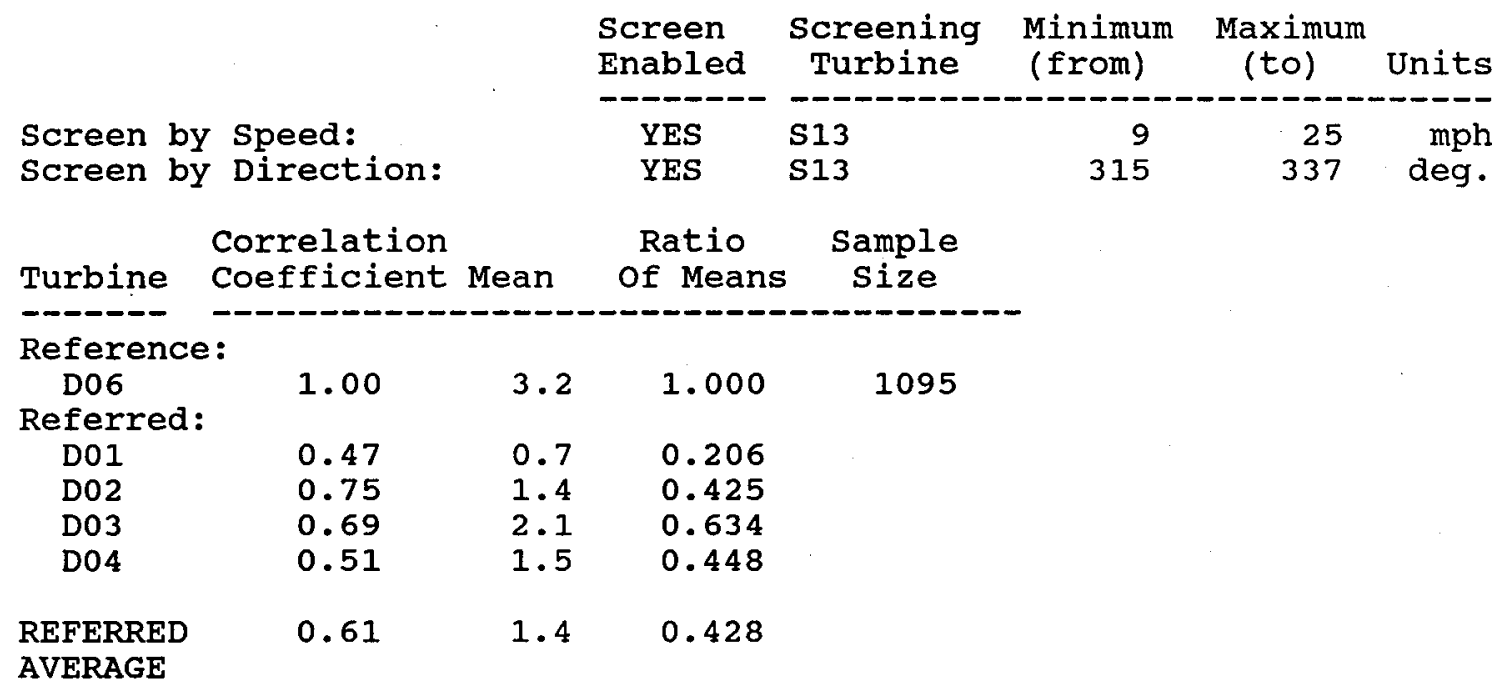


Table 3-7.2e Souza D6 row, moderate winds

WINDFARM CORRELATION REPORT

REPORT INTERVAL: WINTER 87-88 Correlation Variable: ENERGY

Reference Turbine: $\quad$ D06

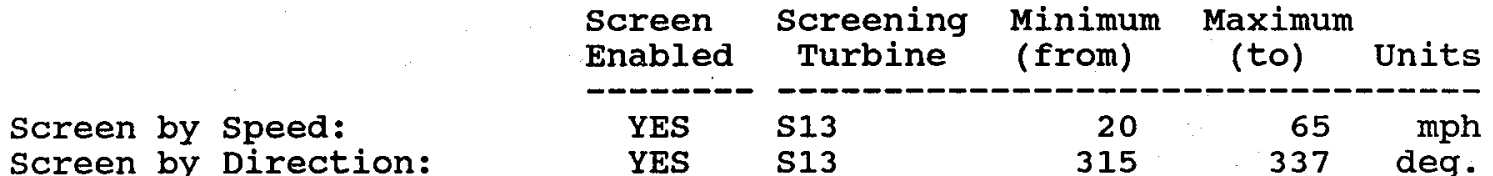

Turbine Coefficient Mean of Means $\begin{gathered}\text { Rample } \\ \text { Cize }\end{gathered}$

Reference:
D06

Referred:

D01

D02

D03

1.00

6.4

1.000

991

D04

0.32

1.4

0.215

0.84

3.8

0.595

0.45

3.7

0.579

REFERRED

0.55

3.5

0.550

AVERAGE

0.54

3.1

0.485

Table 3-7.2f Souza D6 row, high winds

Screen by Speed:

Screen by Direction:

\begin{tabular}{lrrrr}
$\begin{array}{l}\text { Screen } \\
\text { Enabled }\end{array}$ & $\begin{array}{c}\text { Screening } \\
\text { Turbine }\end{array}$ & $\begin{array}{c}\text { Minimum } \\
\text { (from) }\end{array}$ & $\begin{array}{c}\text { Maximum } \\
\text { (to) }\end{array}$ & Units \\
\hline YES & S13 & 25 & 65 & mph \\
YES & S13 & 315 & 337 & deg.
\end{tabular}

\begin{tabular}{llll} 
Turbine & $\begin{array}{l}\text { Correlation } \\
\text { Coefficient Mean }\end{array}$ & $\begin{array}{c}\text { Ratio } \\
\text { of Means }\end{array}$ \\
\hline $\begin{array}{l}\text { Reference: } \\
\text { D06 }\end{array}$ & 1.00 & 7.7 & 1.000 \\
Referred: & & & \\
$\quad$ D01 & 0.21 & 1.7 & 0.221 \\
D02 & 0.79 & 5.2 & 0.672 \\
D03 & 0.42 & 4.2 & 0.538 \\
D04 & 0.48 & 4.7 & 0.602 \\
& & & \\
REFERRED & 0.48 & 4.0 & 0.508
\end{tabular}

AVERAGE 
Table 3-7.2g Souza D6 row, daylight hours

WINDFARM CORRELATION REPORT

REPORT INTERVAL: WINTER 87-88 Correlation Variable: ENERGY

Reference Turbine: D06

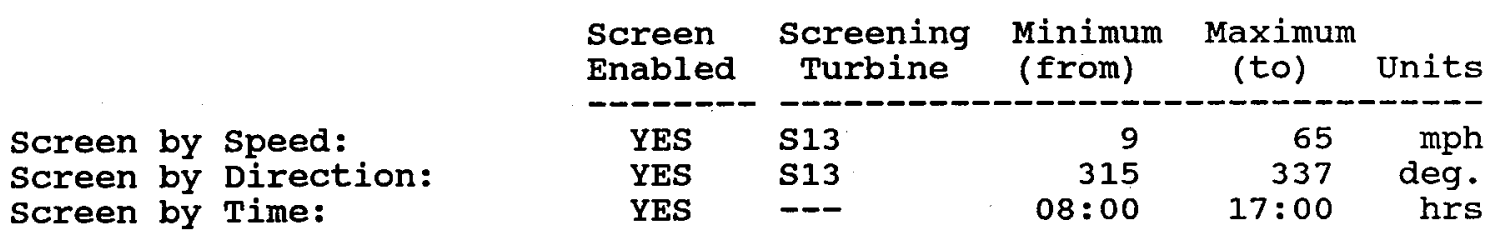

\begin{tabular}{|c|c|c|c|}
\hline Turbine & $\begin{array}{l}\text { Correlation } \\
\text { Coefficient Mean }\end{array}$ & $\begin{array}{l}\text { Ratio } \\
\text { of Means }\end{array}$ & $\begin{array}{l}\text { Sample } \\
\text { Size }\end{array}$ \\
\hline
\end{tabular}

Reference:

$\begin{array}{llll}\text { D06 } & 1.00 & 5.5 & 1.000\end{array}$

Referred:

D01 $0.45 \quad 2.2 \quad 0.396$

$\begin{array}{llll}\text { D02 } & 0.91 & 3.7 & 0.672\end{array}$

$\begin{array}{llll}\mathrm{D} 03 & 0.63 & 3.8 & 0.694\end{array}$

$\begin{array}{llll}\text { D04 } & 0.63 & 3.4 & 0.631\end{array}$

$\begin{array}{llll}\text { REFERRED } & 0.66 & 3.3 & 0.598\end{array}$

AVERAGE

Table 3-7.2h Souza D6 row, nightime hours

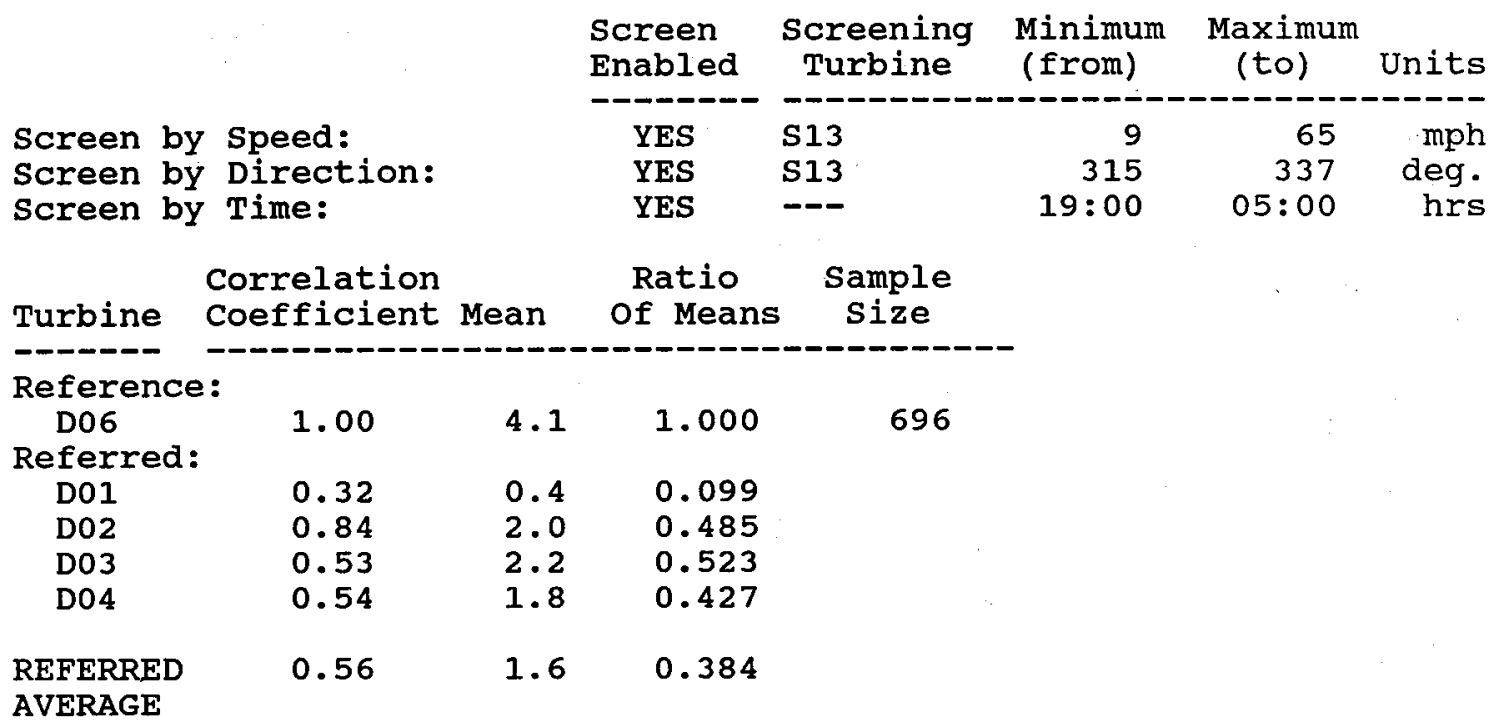


Table 3-7.2i Souza D13 row, parallel winds

WINDFARM CORRELATION REPORT

REPORT INTERVAL: WINTER 87-8

Reference Turbine: $\quad$ D13

\begin{tabular}{|c|c|c|c|c|c|c|}
\hline & & $\begin{array}{l}\text { Screen } \\
\text { Enabled }\end{array}$ & $\begin{array}{l}\text { Screening } \\
\text { Turbine }\end{array}$ & $\begin{array}{l}\text { Minimum } \\
\text { (from) }\end{array}$ & $\begin{array}{l}\text { Maximum } \\
\text { (to) }\end{array}$ & Units \\
\hline Screen by & Speed: & YES & $\mathrm{S} 13$ & 9 & 65 & dit \\
\hline Screen by & Direction: & YES & $\mathrm{S13}$ & 304 & 326 & \\
\hline
\end{tabular}

\begin{tabular}{cccccc} 
Turbine & $\begin{array}{c}\text { Correlation } \\
\text { Coefficient }\end{array}$ & \multicolumn{2}{c}{$\begin{array}{c}\text { Ratio } \\
\text { Mean }\end{array}$ Means } & $\begin{array}{c}\text { Sample } \\
\text { Size }\end{array}$ & $\begin{array}{c}\text { Availability } \\
\%\end{array}$ \\
Reference: & & & & & \\
D13 & 1.00 & 3.5 & 1.000 & 1406 & 83.9 \\
Referred: & & & & & 71.1 \\
D07 & 0.27 & 1.1 & 0.315 & 69.1 \\
D08 & 0.49 & 0.6 & 0.185 & 84.7 \\
D09 & 0.58 & 1.6 & 0.464 & 71.7 \\
D10 & 0.69 & 2.3 & 0.661 & 88.7 \\
D11 & 0.83 & 3.1 & 0.905 & & \\
REFERRED & 0.57 & 1.7 & 0.506 & & 7.1
\end{tabular}

AVERAGE

Note: D12 was not included due to low availability.

Table 3-7.2j Souza D13 row, -22 degrees

\begin{tabular}{|c|c|c|c|c|c|c|c|}
\hline & . & & $\begin{array}{l}\text { Screen } \\
\text { Enabled }\end{array}$ & $\begin{array}{l}\text { Screening } \\
\text { Turbine }\end{array}$ & $\begin{array}{l}\text { Minimum } \\
\text { (from) }\end{array}$ & $\begin{array}{l}\text { Maximum } \\
\text { (to) }\end{array}$ & Units \\
\hline $\begin{array}{l}\text { Screen by } \\
\text { Screen by }\end{array}$ & $\begin{array}{l}\text { Speed: } \\
\text { Direction: }\end{array}$ & & $\begin{array}{l}\text { YES } \\
\text { YES }\end{array}$ & $\begin{array}{l}\mathrm{S} 13 \\
\mathrm{~S} 13\end{array}$ & $\begin{array}{r}9 \\
282\end{array}$ & $\begin{array}{r}65 \\
304\end{array}$ & $\begin{array}{l}\text { mph } \\
\text { deg. }\end{array}$ \\
\hline Turbine & $\begin{array}{l}\text { Correlation } \\
\text { coefficient }\end{array}$ & Mean & $\begin{array}{l}\text { Ratio } \\
\text { of Means }\end{array}$ & $\begin{array}{c}\text { Sample } \\
\text { Size }\end{array}$ & & & \\
\hline Reference & 1.00 & 2.4 & 1.000 & 158 & & & \\
\hline $\begin{array}{l}\text { Referred: } \\
\text { D07 } \\
\text { D08 } \\
\text { D09 } \\
\text { D10 } \\
\text { D11 }\end{array}$ & $\begin{array}{l}0.67 \\
0.75 \\
0.83 \\
0.44 \\
0.95\end{array}$ & $\begin{array}{l}1.0 \\
1.5 \\
2.2 \\
2.0 \\
2.7\end{array}$ & $\begin{array}{l}0.403 \\
0.620 \\
0.919 \\
0.822 \\
1.110\end{array}$ & & & & \\
\hline $\begin{array}{l}\text { REFERRED } \\
\text { AVERAGE }\end{array}$ & 0.73 & 1.9 & 0.775 & & & & \\
\hline
\end{tabular}


Table 3-7.2k Souza D13 row, +22 degrees

WINDFARM CORRELATION REPORT

REPORT INTERVAL: WINTER 87-88 Correlation Variable: ENERGY

Reference Turbine: $\quad$ D13

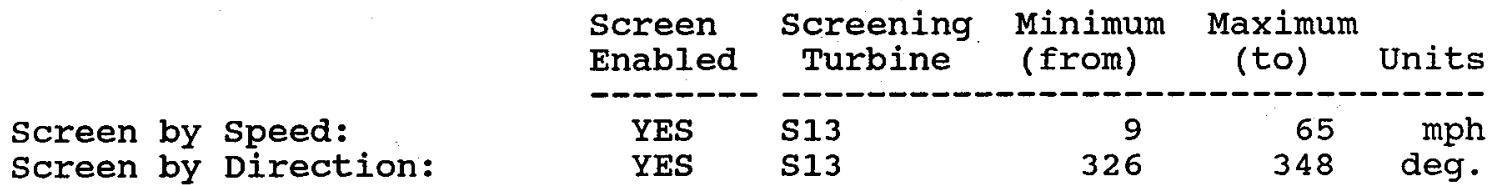

Turbine Coefficient Mean of Means $\begin{array}{cc}\text { Comple } \\ \text { Size }\end{array}$

$\begin{array}{llll}\begin{array}{l}\text { Reference: } \\ \text { D13 }\end{array} & 1.00 & 5.2 & 1.000 \\ \text { Referred: } & & & \\ \text { D07 } & 0.34 & 3.4 & 0.661 \\ \text { D08 } & 0.66 & 2.6 & 0.494 \\ \text { D09 } & 0.74 & 3.8 & 0.736 \\ \text { D10 } & 0.81 & 3.5 & 0.673 \\ \text { D11 } & 0.88 & 5.4 & 1.045\end{array}$

$\begin{array}{llll}\text { REFERRED } & 0.69 & 3.7 & 0.722\end{array}$

AVERAGE

Table 3-7.21 Souza D13 row, low winds

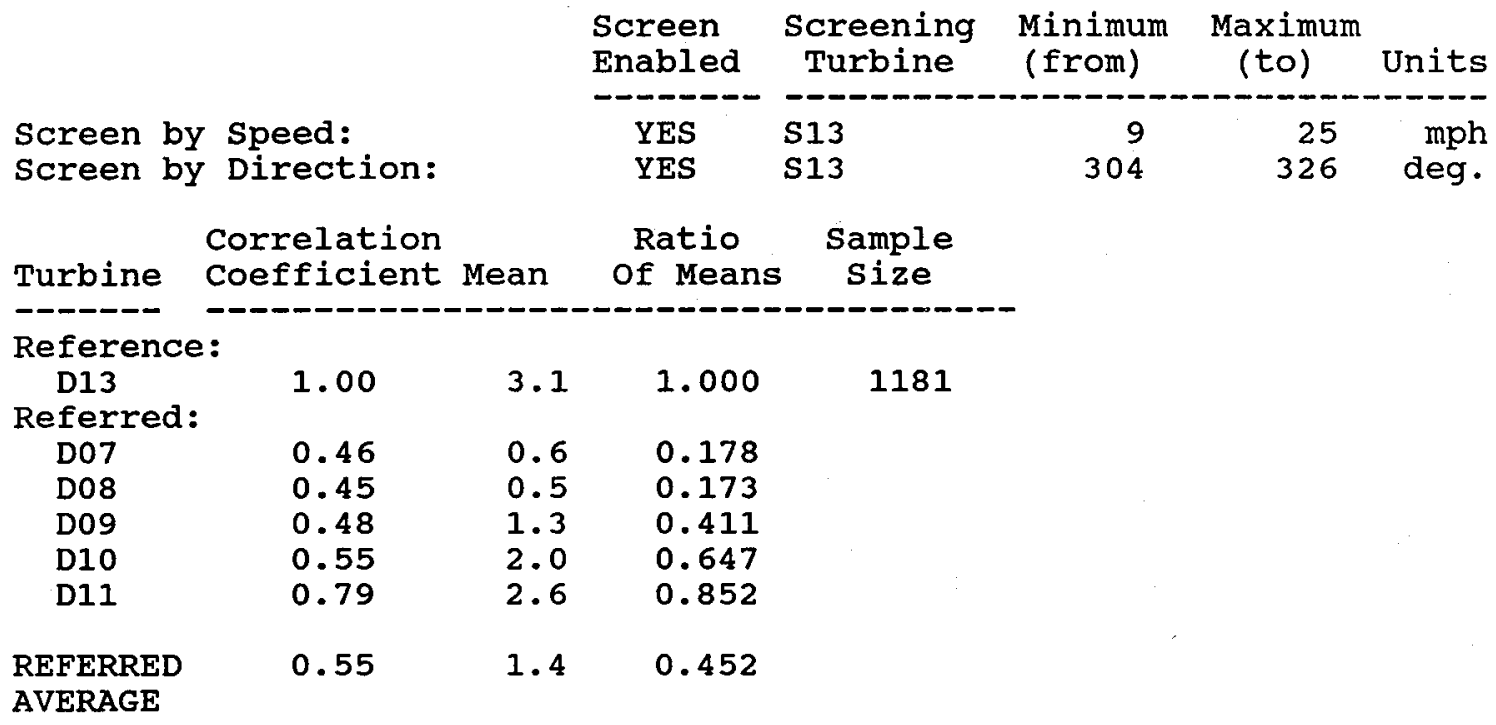


Table 3-7.2m Souza D13 row, moderate winds WINDFARM CORRELATION REPORT

REPORT INTERVAL: WINTER 87-88 Correlation Variable: ENERGY

Reference Turbine: $\quad$ D13

\begin{tabular}{|c|c|c|c|c|c|c|}
\hline & & $\begin{array}{l}\text { Screen } \\
\text { Enabled }\end{array}$ & $\begin{array}{l}\text { Screening } \\
\text { Turbine }\end{array}$ & $\begin{array}{l}\text { Minimum } \\
\text { (from) }\end{array}$ & $\begin{array}{l}\text { Maximum } \\
\text { (to) }\end{array}$ & Units \\
\hline $\begin{array}{l}\text { Screen by } \\
\text { Screen by }\end{array}$ & $\begin{array}{l}\text { Speed: } \\
\text { Direction: }\end{array}$ & $\begin{array}{l}\text { YES } \\
\text { YES }\end{array}$ & $\begin{array}{l}\mathrm{S} 13 \\
\mathrm{~S} 13\end{array}$ & $\begin{array}{r}20 \\
304\end{array}$ & $\begin{array}{r}65 \\
326\end{array}$ & $\begin{array}{l}\text { mph } \\
\text { deg. }\end{array}$ \\
\hline
\end{tabular}

\begin{tabular}{|c|c|c|c|c|}
\hline Turbine & $\begin{array}{l}\text { Correlation } \\
\text { Coefficient }\end{array}$ & Mean & $\begin{array}{l}\text { Ratio } \\
\text { of Means }\end{array}$ & $\begin{array}{l}\text { Sample } \\
\text { Size }\end{array}$ \\
\hline $\begin{array}{l}\text { Reference } \\
\text { D13 } \\
\text { Referred: }\end{array}$ & 1.00 & 5.3 & 1.000 & 624 \\
\hline $\begin{array}{l}\text { D07 } \\
\text { D08 } \\
\text { D09 } \\
\text { D10 } \\
\text { D11 }\end{array}$ & $\begin{array}{r}-0.14 \\
0.42 \\
0.47 \\
0.62 \\
0.73\end{array}$ & $\begin{array}{l}2.1 \\
1.0 \\
2.6 \\
3.2 \\
4.9\end{array}$ & $\begin{array}{l}0.408 \\
0.192 \\
0.496 \\
0.607 \\
0.929\end{array}$ & \\
\hline $\begin{array}{l}\text { REFERRED } \\
\text { AVERAGE }\end{array}$ & 0.42 & 2.8 & 0.526 & \\
\hline
\end{tabular}

Table 3-7.2n Souza D13 row, high winds

\begin{tabular}{|c|c|c|c|c|c|c|c|}
\hline & & & $\begin{array}{l}\text { Screen } \\
\text { Enabled }\end{array}$ & $\begin{array}{l}\text { Screening } \\
\text { Turbine }\end{array}$ & $\begin{array}{l}\text { Minimum } \\
\text { (from) }\end{array}$ & $\begin{array}{l}\text { Maximum } \\
\text { (to) }\end{array}$ & Units \\
\hline $\begin{array}{l}\text { Screen by } \\
\text { Screen by }\end{array}$ & $\begin{array}{l}\text { Speed: } \\
\text { Direction: }\end{array}$ & & $\begin{array}{l}\text { YES } \\
\text { YES }\end{array}$ & $\begin{array}{l}S 13 \\
S 13\end{array}$ & $\begin{array}{r}25 \\
304\end{array}$ & $\begin{array}{r}65 \\
326\end{array}$ & $\begin{array}{l}\text { mph } \\
\text { deg. }\end{array}$ \\
\hline Turbine & $\begin{array}{l}\text { Correlation } \\
\text { Coefficient }\end{array}$ & Mean & $\begin{array}{l}\text { Ratio } \\
\text { of Means }\end{array}$ & $\begin{array}{c}\text { Sample } \\
\text { Size }\end{array}$ & & & \\
\hline Reference: & & & & & & & \\
\hline $\begin{array}{c}\text { D13 } \\
\text { Referred: }\end{array}$ & 1.00 & 5.3 & 1.000 & 228 & & & \\
\hline D07 & -0.30 & 3.9 & 0.734 & & & & \\
\hline D08 & 0.49 & 1.2 & 0.223 & & & & \\
\hline D09 & 0.63 & 3.3 & 0.629 & & & & \\
\hline D10 & 0.82 & 3.7 & 0.700 & & & & \\
\hline $\mathrm{D} 11$ & 0.85 & 5.6 & 1.073 & & & & \\
\hline $\begin{array}{l}\text { REFERRED } \\
\text { AVERAGE }\end{array}$ & 0.50 & 3.5 & 0.672 & & & & \\
\hline
\end{tabular}


Table 3-7.20 Souza D13 row, daylight hours

WINDFARM CORRELATION REPORT

REPORT INTERVAL: WINTER 87-88 Correlation Variable: ENERGY

Reference Turbine: D13

\begin{tabular}{lcrrrr} 
& $\begin{array}{c}\text { Screen } \\
\text { Enabled }\end{array}$ & $\begin{array}{c}\text { Screening } \\
\text { Turbine }\end{array}$ & $\begin{array}{l}\text { Minimum } \\
\text { (from) }\end{array}$ & $\begin{array}{r}\text { Maximum } \\
\text { (to) }\end{array}$ & Units \\
\hline Screen by Speed: & YES & S13 & 9 & 65 & mph \\
Screen by Direction: & YES & S13 & 304 & 326 & deg. \\
Screen by Time: & YES & -- & $08: 00$ & $17: 00$ & hrs
\end{tabular}

Correlation
Turbine Coefficient Mean Of Means Sample
Size

Reference:

$\begin{array}{lllll}\text { D13 } & 1.00 & 3.3 & 1.000 & 215\end{array}$

Referred:

$\begin{array}{llll}\mathrm{D} 07 & 0.54 & 1.9 & 0.564\end{array}$

$\begin{array}{llll}\text { D08 } & 0.56 & 0.8 & 0.242\end{array}$

$\begin{array}{llll}\text { D09 } & 0.73 & 2.0 & 0.621\end{array}$

$\begin{array}{llll}\text { D10 } & 0.85 & 2.1 & 0.646\end{array}$

$\begin{array}{llll}\text { D11 } & 0.86 & 3.4 & 1.043\end{array}$

$\begin{array}{llll}\text { REFERRED } & 0.71 & 2.0 & 0.623\end{array}$

AVERAGE

Table 3-7.2p Souza Dl3 row, nightime hours

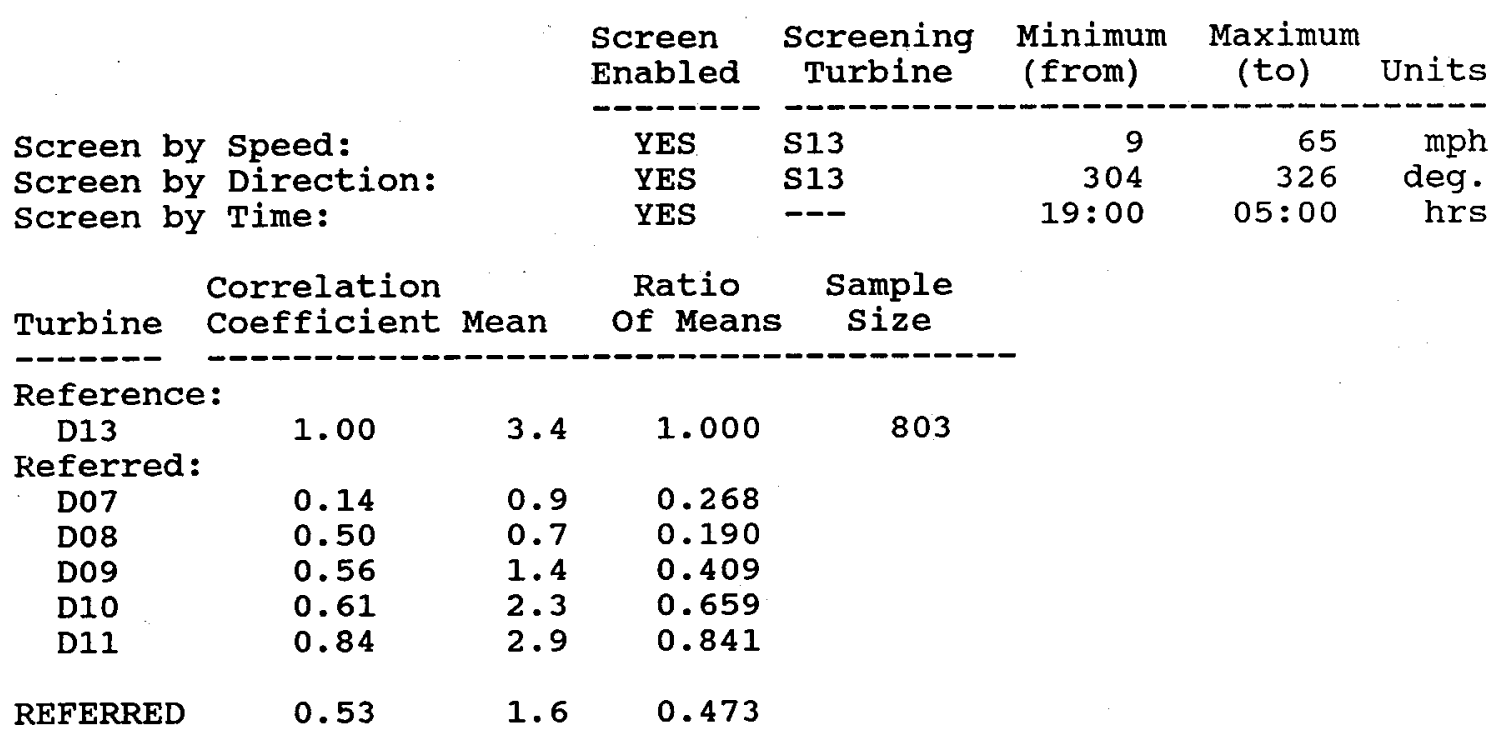


Table 3-7.2q Souza E6 row, parallel winds

WINDFARM CORRELATION REPORT

REPORT INTERVAL: WINTER 87-88 Correlation Variable: ENERGY

Reference Turbine: $\quad$ E06

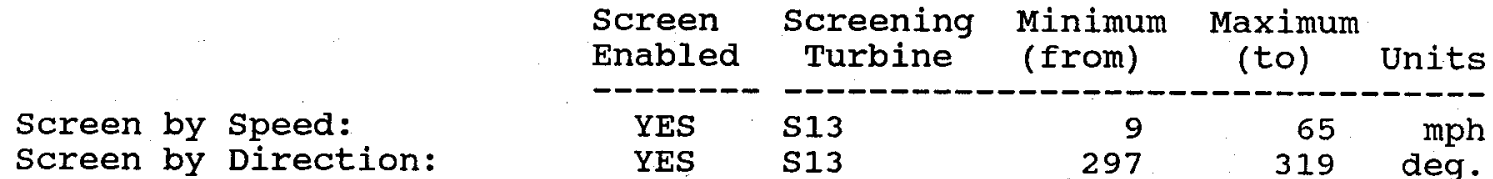

\begin{tabular}{lccccr} 
Turbine & $\begin{array}{l}\text { Correlation } \\
\text { Coefficient Mean }\end{array}$ & $\begin{array}{c}\text { Ratio } \\
\text { Of Means }\end{array}$ & $\begin{array}{c}\text { Sample } \\
\text { Size }\end{array}$ & $\begin{array}{r}\text { Availabi } \\
\%\end{array}$ \\
\hline $\begin{array}{l}\text { Reference: } \\
\text { E06 }\end{array}$ & 1.00 & 2.7 & 1.000 & 896 & 93.6 \\
$\begin{array}{l}\text { Referred: } \\
\text { E01 }\end{array}$ & 0.94 & 2.4 & 0.916 & & 93.7 \\
E03 & 0.91 & 2.6 & 0.990 & & 93.4 \\
E04 & 0.95 & 2.3 & 0.873 & & 92.6 \\
E05 & 0.83 & 1.3 & 0.484 & & 93.7
\end{tabular}

$\begin{array}{lllll}\text { REFERRED } & 0.91 & 2.2 & 0.816 & 93.4\end{array}$

AVERAGE

Note: E02 was not included due to low availability.

Table 3-7.2r Souza E6 row, -22 degrees

\begin{tabular}{|c|c|c|c|c|c|c|c|}
\hline & & & $\begin{array}{l}\text { Screen } \\
\text { Enabled }\end{array}$ & $\begin{array}{l}\text { Screening } \\
\text { Turbine }\end{array}$ & $\begin{array}{l}\text { Minimum } \\
\text { (from) }\end{array}$ & $\begin{array}{l}\text { Maximum } \\
\text { (to) }\end{array}$ & Units \\
\hline $\begin{array}{l}\text { Screen by } \\
\text { Screen by }\end{array}$ & $\begin{array}{l}\text { Speed: } \\
\text { Direction: }\end{array}$ & & $\begin{array}{l}\text { YES } \\
\text { YES }\end{array}$ & $\begin{array}{l}\mathrm{S} 13 \\
\mathrm{~S} 13\end{array}$ & $\begin{array}{r}9 \\
275\end{array}$ & $\begin{array}{r}65 \\
297\end{array}$ & $\begin{array}{l}\text { mph } \\
\text { deg. }\end{array}$ \\
\hline Turbine & $\begin{array}{l}\text { Correlation } \\
\text { Coefficient }\end{array}$ & Mean & $\begin{array}{l}\text { Ratio } \\
\text { of Means }\end{array}$ & $\begin{array}{l}\text { Sample } \\
\text { Size }\end{array}$ & & & \\
\hline $\begin{array}{l}\text { Reference } \\
\text { E06 } \\
\text { Referred: }\end{array}$ & 1.00 & 3.0 & 1.000 & 82 & & & \\
\hline $\begin{array}{l}\text { E01 } \\
\text { E03 } \\
\text { E04 } \\
\text { E05 }\end{array}$ & $\begin{array}{l}0.97 \\
0.87 \\
0.93 \\
0.92\end{array}$ & $\begin{array}{l}2.4 \\
1.7 \\
1.9 \\
2.2\end{array}$ & $\begin{array}{l}0.816 \\
0.562 \\
0.651 \\
0.746\end{array}$ & & & & \\
\hline $\begin{array}{l}\text { REFERRED } \\
\text { AVERAGE }\end{array}$ & 0.92 & 2.1 & 0.694 & & & & \\
\hline
\end{tabular}


Table 3-7.2s Souza E6 row, +22 degrees

WINDFARM CORREIATION REPORT

REPORT INTERVAL: WINTER 87-88 Correlation Variable: ENERGY

Reference Turbine: $\quad$ E06

\begin{tabular}{|c|c|c|c|c|c|}
\hline & & $\begin{array}{l}\text { Screen } \\
\text { Enabled }\end{array}$ & $\begin{array}{l}\text { Screening } \\
\text { Turbine }\end{array}$ & $\begin{array}{l}\text { Minimum } \\
\text { (from) }\end{array}$ & $\begin{array}{c}\text { Maximum } \\
\text { (to) }\end{array}$ \\
\hline $\begin{array}{l}\text { Screen b } \\
\text { Screen by }\end{array}$ & $\begin{array}{l}\text { Speed: } \\
\text { Direction: }\end{array}$ & $\begin{array}{l}\text { YES } \\
\text { YES }\end{array}$ & $\begin{array}{l}\mathrm{S} 13 \\
\mathrm{~S} 13\end{array}$ & $\begin{array}{r}9 \\
319\end{array}$ & $\begin{array}{r}65 \\
341\end{array}$ \\
\hline
\end{tabular}

$\begin{array}{lcccc}\text { Turbine } & \begin{array}{l}\text { Correlation } \\ \text { Coefficient Mean }\end{array} & \begin{array}{c}\text { Ratio } \\ \text { Of Means }\end{array} & \begin{array}{c}\text { Sample } \\ \text { Size }\end{array} \\ \text { Reference: } & & & & \\ \quad \text { E06 } & 1.00 & 5.1 & 1.000 & 1426 \\ \text { Referred: } & & & & \\ \text { E01 } & 0.93 & 5.2 & 1.019 & \\ \text { E03 } & 0.87 & 5.6 & 1.110 & \\ \text { E04 } & 0.93 & 5.4 & 1.071 & \\ \text { E05 } & 0.90 & 4.4 & 0.864 & \end{array}$

REFERRED $\quad 0.91 \quad 5.2 \quad 1.016$

AVERAGE

Table 3-7.2t Souza E6 row, low winds

\begin{tabular}{|c|c|c|c|c|}
\hline & $\begin{array}{l}\text { Screen } \\
\text { Enabled }\end{array}$ & $\begin{array}{c}\text { Screening } \\
\text { Turbine }\end{array}$ & $\begin{array}{l}\text { Minimum } \\
\text { (from) }\end{array}$ & $\begin{array}{l}\text { Maximum } \\
\text { (to) }\end{array}$ \\
\hline $\begin{array}{l}\text { Screen by Speed: } \\
\text { Screen by Direction: }\end{array}$ & $\begin{array}{l}\text { YES } \\
\text { YES }\end{array}$ & $\begin{array}{l}\text { S13 } \\
\text { S13 }\end{array}$ & $\begin{array}{r}9 \\
297\end{array}$ & $\begin{array}{r}25 \\
319\end{array}$ \\
\hline
\end{tabular}

$\begin{array}{lcccc}\text { Turbine } & \begin{array}{l}\text { Correlation } \\ \text { Coefficient Mean }\end{array} & \begin{array}{c}\text { Ratio } \\ \text { Of Means }\end{array} & \begin{array}{c}\text { Sample } \\ \text { Size }\end{array} \\ \text { Reference: } & & & & \\ \quad \text { E06 } & 1.00 & 2.3 & 1.000 & 823 \\ \text { Referred: } & & & & \\ \quad \text { E01 } & 0.92 & 2.0 & 0.900 & \\ \text { E03 } & 0.88 & 2.2 & 0.972 & \\ \text { E04 } & 0.95 & 1.9 & 0.842 & \\ \text { E05 } & 0.79 & 0.9 & 0.395 & \\ \text { REFERRED } & 0.89 & 1.8 & 0.777 & \\ \text { AVERAGE } & & & \end{array}$


Table 3-7.2u Souza E6 row, moderate winds

WINDFARM CORRELATION REPORT

REPORT INTERVAL: WINTER 87-88 Correlation Variable: ENERGY

Reference Turbine: E06

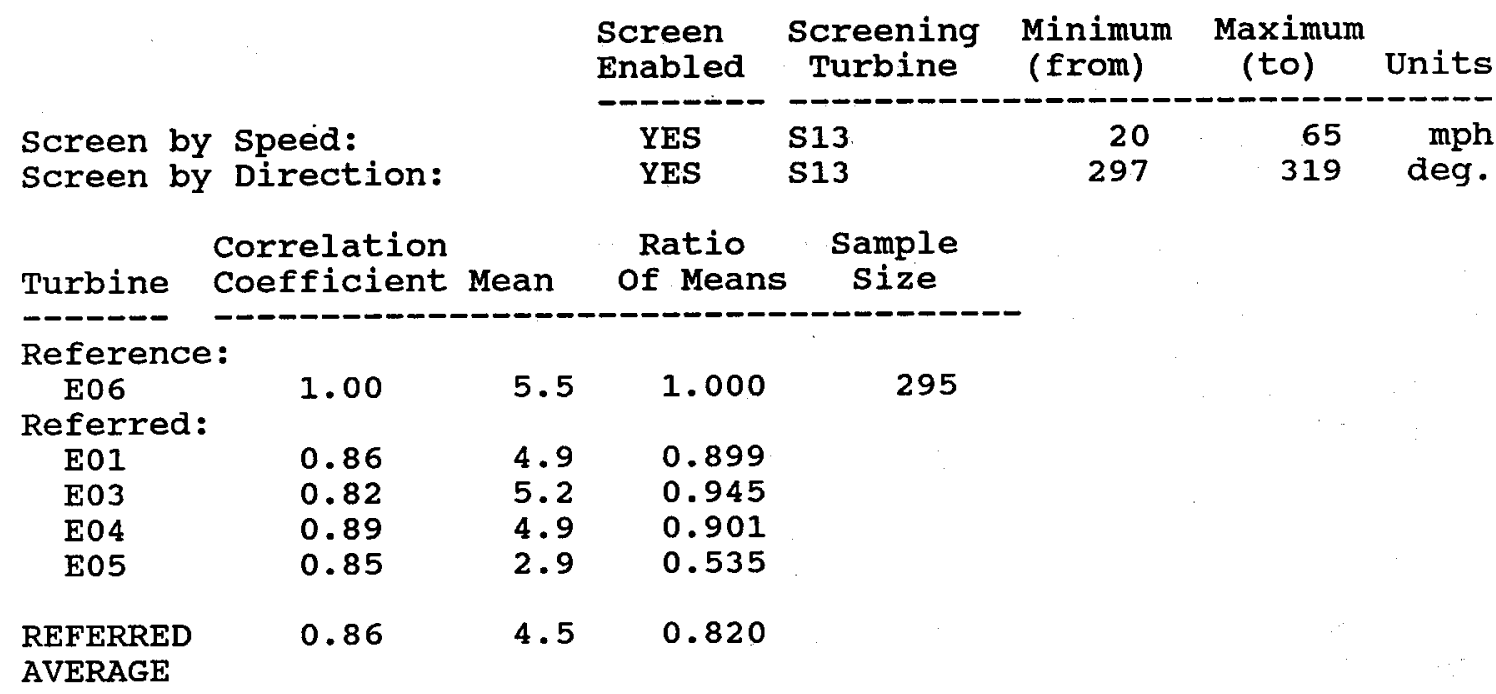

Table 3-7.2v Souza E6 row, high winds

\begin{tabular}{|c|c|c|c|c|c|c|c|}
\hline & & & $\begin{array}{l}\text { Screen } \\
\text { Enabled }\end{array}$ & $\begin{array}{l}\text { Screening } \\
\text { Turbine }\end{array}$ & $\begin{array}{l}\text { Minimum } \\
\text { (from) }\end{array}$ & $\begin{array}{l}\text { Maximum } \\
\text { (to) }\end{array}$ & Units \\
\hline $\begin{array}{l}\text { Screen by } \\
\text { Screen by }\end{array}$ & $\begin{array}{l}\text { Speed: } \\
\text { Direction: }\end{array}$ & & $\begin{array}{l}\text { YES } \\
\text { YES }\end{array}$ & $\begin{array}{l}\text { S13 } \\
\text { S13 }\end{array}$ & $\begin{array}{r}25 \\
297\end{array}$ & $\begin{array}{r}65 \\
319\end{array}$ & $\begin{array}{l}\text { mph } \\
\text { deg. }\end{array}$ \\
\hline Turbine & $\begin{array}{l}\text { Correlation } \\
\text { Coefficient }\end{array}$ & Mean & $\begin{array}{l}\text { Ratio } \\
\text { Of Means }\end{array}$ & $\begin{array}{l}\text { Sample } \\
\text { Size }\end{array}$ & & & \\
\hline $\begin{array}{l}\text { Reference } \\
\text { E06 } \\
\text { Referred: } \\
\text { E01 } \\
\text { E03 } \\
\text { E04 } \\
\text { E05 }\end{array}$ & $\begin{array}{l}1.00 \\
0.55 \\
0.65 \\
0.65 \\
0.67\end{array}$ & $\begin{array}{l}7.3 \\
7.1 \\
7.7 \\
7.2 \\
5.8\end{array}$ & $\begin{array}{l}1.000 \\
0.968 \\
1.053 \\
0.977 \\
0.788\end{array}$ & 75 & & & \\
\hline $\begin{array}{l}\text { REFERRED } \\
\text { AVERAGE }\end{array}$ & 0.63 & 7.0 & 0.947 & & & & \\
\hline
\end{tabular}


Table 3-7.2w Souza E6 row, daylight hours

WINDFARM CORRELATION REPORT

REPORT INTERVAL: WINTER 87-88 Correlation Variable: ENERGY

Reference Turbine: E06

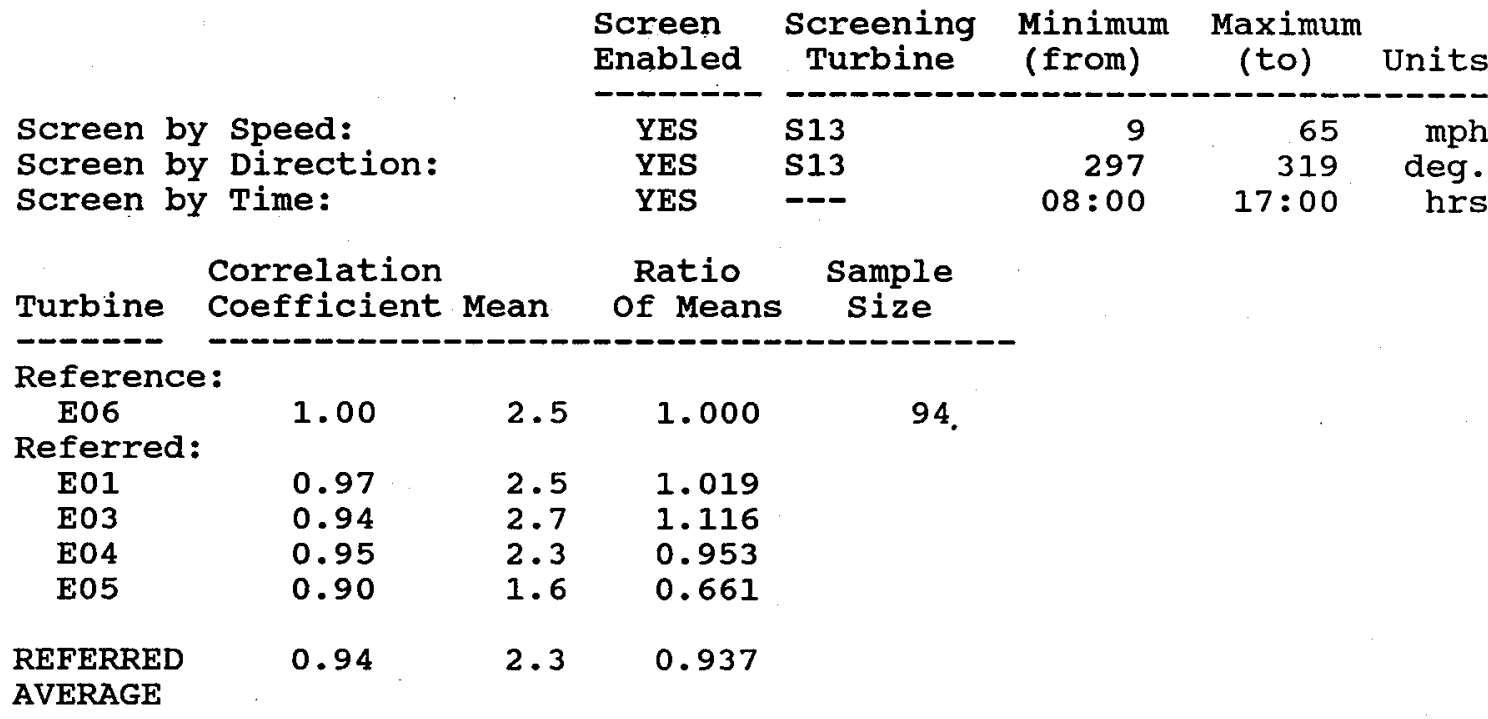

Table 3-7.2x Souza E6 row, nightime hours

\begin{tabular}{|c|c|c|c|c|c|c|c|}
\hline & & & $\begin{array}{l}\text { Screen } \\
\text { Enabled }\end{array}$ & $\begin{array}{l}\text { Screening } \\
\text { Turbine }\end{array}$ & $\begin{array}{l}\text { Minimum } \\
\text { (from) }\end{array}$ & $\begin{array}{l}\text { Maximum } \\
\text { (to) }\end{array}$ & Units \\
\hline Screen by & Speed: & & YES & $\mathrm{S} 13$ & 9 & 65 & $\mathrm{mph}$ \\
\hline Screen by & Direction: & & YES & $\mathrm{s} 13$ & 297 & 319 & deg. \\
\hline Screen by & Time: & & YES & --- & $19: 00$ & $05: 00$ & hrs \\
\hline Turbine & $\begin{array}{l}\text { Correlation } \\
\text { Coefficient }\end{array}$ & Mean & $\begin{array}{l}\text { Ratio } \\
\text { of Means }\end{array}$ & $\begin{array}{c}\text { Sample } \\
\text { Size }\end{array}$ & & & \\
\hline Reference & & & & & & & \\
\hline E06 & 1.00 & 2.7 & 1.000 & 576 & & & \\
\hline $\begin{array}{l}\text { Referred: } \\
\text { E01 }\end{array}$ & 0.94 & 2.5 & 0.906 & & & & \\
\hline E03 & $\begin{array}{l}0.94 \\
0.90\end{array}$ & $\begin{array}{l}2.5 \\
2.6\end{array}$ & 0.968 & & & & \\
\hline E04 & 0.95 & 2.3 & 0.865 & & & & \\
\hline E05 & 0.82 & 1.3 & 0.471 & & & & \\
\hline $\begin{array}{l}\text { REFERRED } \\
\text { AVERAGE }\end{array}$ & 0.90 & 2.2 & 0.802 & & & & \\
\hline
\end{tabular}


Table 3-7.2y Souza El0 row, parallel winds

WINDFARM CORRELATION REPORT

REPORT INTERVAL: WINTER 87-88 Correlation Variable: ENERGY

Reference Turbine: $\quad$ E10

\begin{tabular}{|c|c|c|c|c|c|}
\hline & $\begin{array}{l}\text { Screen } \\
\text { Enabled }\end{array}$ & $\begin{array}{l}\text { Screening } \\
\text { Turbine }\end{array}$ & $\begin{array}{l}\text { Minimum } \\
\text { (from) }\end{array}$ & $\begin{array}{l}\text { Maximum } \\
\text { (to) }\end{array}$ & Units \\
\hline $\begin{array}{l}\text { Screen by Speed: } \\
\text { Screen by Direction: }\end{array}$ & $\begin{array}{l}\text { YES } \\
\text { YES }\end{array}$ & $\begin{array}{l}\text { S13 } \\
\text { S13 }\end{array}$ & $\begin{array}{r}9 \\
327\end{array}$ & $\begin{array}{r}65 \\
349\end{array}$ & $\begin{array}{l}\text { mph } \\
\text { deg. }\end{array}$ \\
\hline
\end{tabular}

correlation Ratio sample Availability

Turbine Coefficient Mean of Means Size $\%$
Reference:

Reference:

1.00

6.31 .000

$898 \quad 85.0$

Referred:

E07

0.75

2.7

0.427

0.61

2.5

0.400

90.0

E08

0.77

$3 \cdot 3$

0.528

93.0

85.0

REFERRED

0.71

2.8

0.452

89.3

AVERAGE

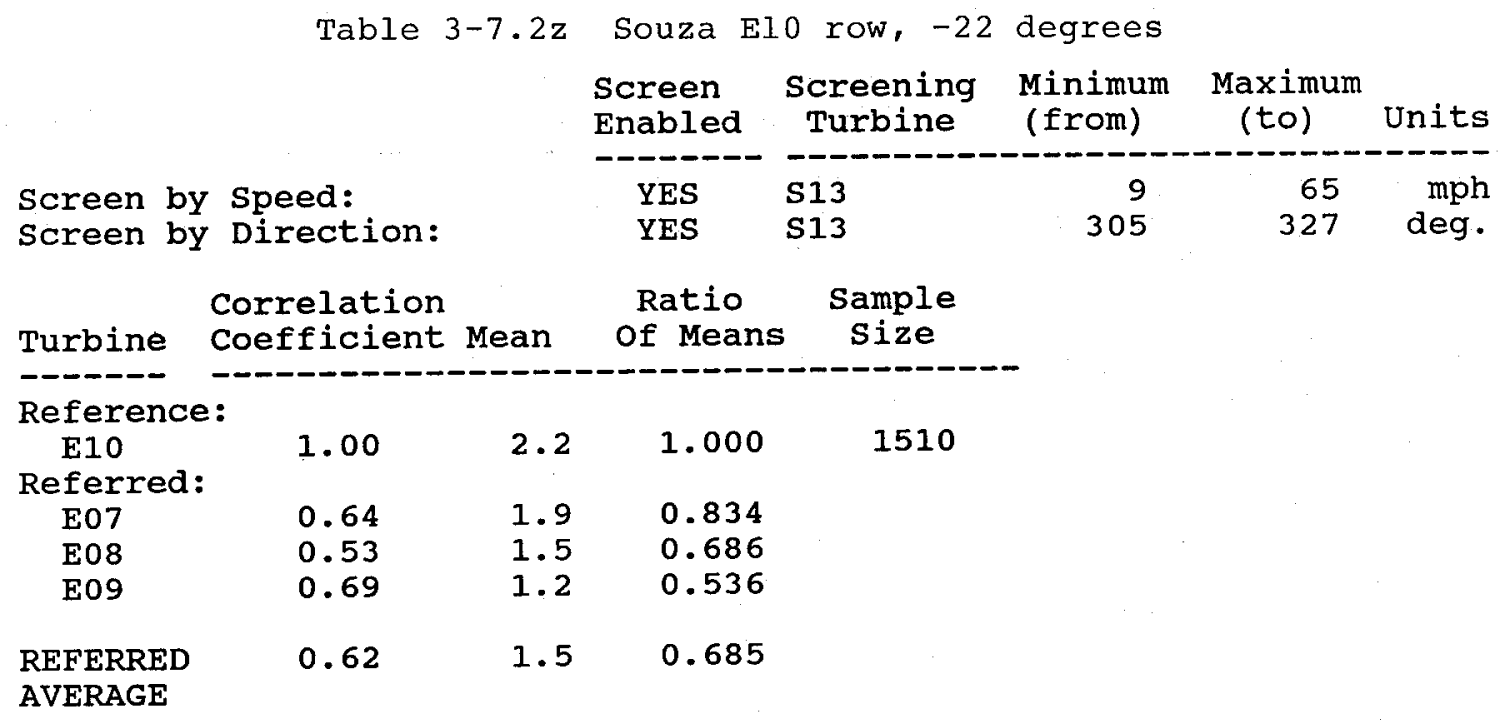


Table 3-7.2aa Souza El0 row, +22 degrees

WINDFARM CORRELATION REPORT

REPORT INTERVAL: WINTER 87-88 Correlation Variable: ENERGY

Reference Turbine: $\quad$ E10

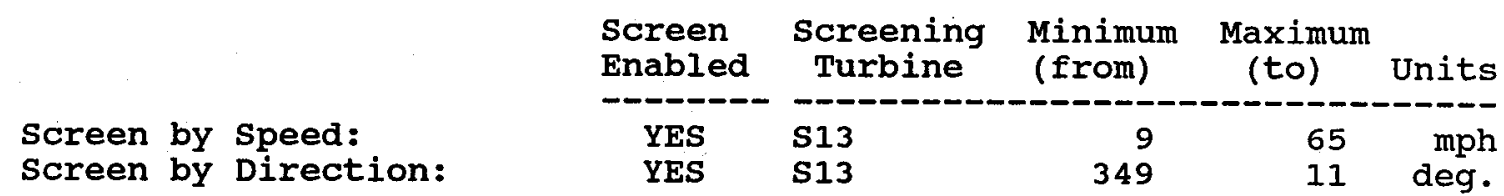

\begin{tabular}{lcccc} 
Turbine & $\begin{array}{l}\text { Correlation } \\
\text { Coefficient Mean }\end{array}$ & $\begin{array}{c}\text { Ratio } \\
\text { Of Means }\end{array}$ & $\begin{array}{c}\text { Sample } \\
\text { Size }\end{array}$ \\
\hline $\begin{array}{l}\text { Reference: } \\
\text { E10 }\end{array}$ & 1.00 & 6.7 & 1.000 & 205 \\
Referred: & & & & \\
E07 & 0.83 & 3.2 & 0.480 & \\
E08 & 0.76 & 3.4 & 0.503 & \\
E09 & 0.88 & 4.3 & 0.632 &
\end{tabular}

$\begin{array}{llll}\text { REFERRED } & 0.82 & 3.6 & 0.538\end{array}$

AVERAGE

Table 3-7.2bb Souza E10 row, low winds

\begin{tabular}{|c|c|c|c|c|c|c|c|}
\hline & & & $\begin{array}{l}\text { Screen } \\
\text { Enabled }\end{array}$ & $\begin{array}{l}\text { Screening } \\
\text { Turbine }\end{array}$ & $\begin{array}{l}\text { Minimum } \\
\text { (from) }\end{array}$ & $\begin{array}{l}\text { Maximum } \\
\text { (to) }\end{array}$ & Units \\
\hline $\begin{array}{l}\text { Screen by } \\
\text { Screen by }\end{array}$ & $\begin{array}{l}\text { Speed: } \\
\text { Direction: }\end{array}$ & & $\begin{array}{l}\text { YES } \\
\text { YES }\end{array}$ & $\begin{array}{l}S 13 \\
\text { S13 }\end{array}$ & $\begin{array}{r}9 \\
327\end{array}$ & $\begin{array}{r}25 \\
349\end{array}$ & $\begin{array}{l}\text { mph } \\
\text { deg. }\end{array}$ \\
\hline Turbine & $\begin{array}{l}\text { Correlation } \\
\text { Coefficient }\end{array}$ & Mean & $\begin{array}{l}\text { Ratio } \\
\text { of Means }\end{array}$ & $\begin{array}{c}\text { Sample } \\
\text { Size }\end{array}$ & & & \\
\hline $\begin{array}{l}\text { Reference } \\
\text { E10 } \\
\text { Referred: } \\
\text { E07 } \\
\text { E08 } \\
\text { E09 }\end{array}$ & $\begin{array}{l}1.00 \\
0.82 \\
0.72 \\
0.77\end{array}$ & $\begin{array}{l}1.6 \\
1.4 \\
1.6\end{array}$ & $\begin{array}{l}1.000 \\
0.362 \\
0.327 \\
0.363\end{array}$ & 479 & & & \\
\hline $\begin{array}{l}\text { REFERRED } \\
\text { AVERAGE }\end{array}$ & 0.77 & 1.5 & 0.351 & & & & \\
\hline
\end{tabular}




\section{Table 3-7.2cc Souza El0 row, moderate winds}

WINDFARM CORRELATION REPORT

REPORT INTERVAL: WINTER 87-88 Correlation Variable: ENERGY

Reference Turbine: $\quad$ E10

\begin{tabular}{|c|c|c|c|c|c|c|c|}
\hline & & & $\begin{array}{l}\text { Screen } \\
\text { Enabled }\end{array}$ & $\begin{array}{l}\text { Screening } \\
\text { Turbine }\end{array}$ & $\begin{array}{l}\text { Minimum } \\
\text { (from) }\end{array}$ & $\begin{array}{l}\text { Maximum } \\
\text { (to) }\end{array}$ & Units \\
\hline $\begin{array}{l}\text { Screen by } \\
\text { Screen by }\end{array}$ & $\begin{array}{l}\text { Speed: } \\
\text { Direction: }\end{array}$ & & $\begin{array}{l}\text { YES } \\
\text { YES }\end{array}$ & $\begin{array}{l}\text { S13 } \\
\text { S13 }\end{array}$ & $\begin{array}{r}20 \\
327\end{array}$ & $\begin{array}{r}65 \\
349\end{array}$ & $\begin{array}{l}\text { mph } \\
\text { deg. }\end{array}$ \\
\hline Turbine & $\begin{array}{l}\text { Correlation } \\
\text { Coefficient }\end{array}$ & Mean & $\begin{array}{l}\text { Ratio } \\
\text { of Means }\end{array}$ & $\begin{array}{c}\text { Sample } \\
\text { Size }\end{array}$ & & & \\
\hline Reference & 1.00 & 7.8 & 1.000 & 637 & & & \\
\hline $\begin{array}{c}\text { Referred: } \\
\text { E07 } \\
\text { E08 } \\
\text { E09 }\end{array}$ & $\begin{array}{l}0.55 \\
0.37 \\
0.68\end{array}$ & $\begin{array}{l}3.4 \\
3.2 \\
4.4\end{array}$ & $\begin{array}{l}0.440 \\
0.412 \\
0.562\end{array}$ & & & & \\
\hline $\begin{array}{l}\text { REFERRED } \\
\text { AVERAGE }\end{array}$ & 0.53 & 3.7 & 0.471 & & & & \\
\hline
\end{tabular}

Table 3-7.2dd Souza El0 row, high winds

Screen by speed:

Screen by Direction:

Correlation

Turbine Coefficient Mean

\begin{tabular}{lrrrr}
$\begin{array}{c}\text { Screen } \\
\text { Enabled }\end{array}$ & $\begin{array}{c}\text { Screening } \\
\text { Turbine }\end{array}$ & $\begin{array}{c}\text { Minimum } \\
\text { (from) }\end{array}$ & $\begin{array}{c}\text { Maximum } \\
\text { (to) }\end{array}$ & Units \\
\hline YES & S13 & 25 & 65 & mph \\
YES & S13 & 327 & 349 & deg.
\end{tabular}

\section{Reference:}

E10

Referred:

E07

E08

E09

REFERRED

AVERAGE
1.00

8.5

Ratio

of Means

Sample

size 
Table 3-7.2ee Souza El0 row, daylight hours

WINDFARM CORRELATION REPORT

REPORT INTERVAL: WINTER 87-88 Correlation Variable: ENERGY Reference Turbine: $\quad$ E10

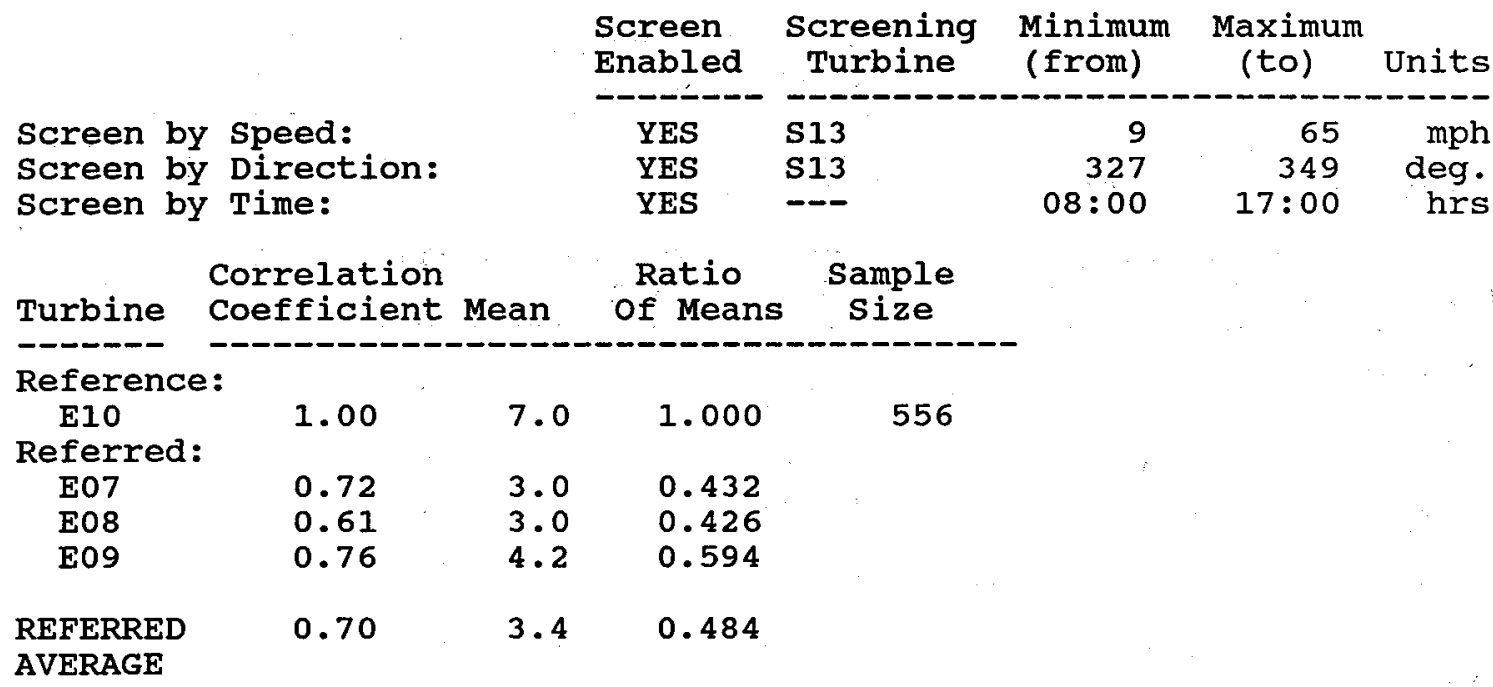

Table 3-7.2ff Souza El0 row, nightime hours

\begin{tabular}{|c|c|c|c|c|c|c|c|}
\hline & & & $\begin{array}{l}\text { Screen } \\
\text { Enabled }\end{array}$ & $\begin{array}{l}\text { Screening } \\
\text { Turbine }\end{array}$ & $\begin{array}{l}\text { Minimum } \\
\text { (from) }\end{array}$ & $\begin{array}{l}\text { Maximum } \\
\quad(t o)\end{array}$ & Units \\
\hline $\begin{array}{l}\text { Screen by } \\
\text { Screen by } \\
\text { Screen by }\end{array}$ & $\begin{array}{l}\text { Speed: } \\
\text { Direction: } \\
\text { Time: }\end{array}$ & & $\begin{array}{l}\text { YES } \\
\text { YES } \\
\text { YES }\end{array}$ & $\begin{array}{l}\mathrm{S} 13 \\
\mathrm{~S} 13 \\
-\end{array}$ & $\begin{array}{r}9 \\
327 \\
19: 00\end{array}$ & $\begin{array}{r}65 \\
349 \\
05: 00\end{array}$ & $\begin{array}{l}\text { mph } \\
\text { deg. } \\
\text { hrs }\end{array}$ \\
\hline Turbine & $\begin{array}{l}\text { Correlation } \\
\text { Coefficient }\end{array}$ & Mean & $\begin{array}{l}\text { Ratio } \\
\text { of Means }\end{array}$ & $\begin{array}{c}\text { Sample } \\
\text { Size }\end{array}$ & & & \\
\hline $\begin{array}{l}\text { Reference } \\
\text { E10 } \\
\text { Referred: }\end{array}$ & 1.00 & 5.3 & 1.000 & 187 & & & \\
\hline $\begin{array}{l}\text { E07 } \\
\text { E08 } \\
\text { E09 }\end{array}$ & $\begin{array}{l}0.81 \\
0.67 \\
0.80\end{array}$ & $\begin{array}{l}2.2 \\
1.7 \\
2.0\end{array}$ & $\begin{array}{l}0.413 \\
0.320 \\
0.383\end{array}$ & & & & \\
\hline $\begin{array}{l}\text { REFERRED } \\
\text { AVERAGE }\end{array}$ & 0.76 & 2.0 & 0.372 & & & & \\
\hline
\end{tabular}


Table 3-7.2gg Souza F9 row, parallel winds

WINDFARM CORRELATION REPORT

REPORT INTERVAL: WINTER 87-88 Correlation Variable: ENERGY

Reference Turbine: $\quad$ F09

\begin{tabular}{|c|c|c|c|c|c|}
\hline & & $\begin{array}{l}\text { Screen } \\
\text { Enabled }\end{array}$ & $\begin{array}{l}\text { Screening } \\
\text { Turbine }\end{array}$ & $\begin{array}{l}\text { Minimum } \\
\text { (from) }\end{array}$ & $\begin{array}{l}\text { Maximum } \\
\text { (to) }\end{array}$ \\
\hline $\begin{array}{l}\text { Screen by } \\
\text { Screen by }\end{array}$ & $\begin{array}{l}\text { Speed: } \\
\text { Direction: }\end{array}$ & $\begin{array}{l}\text { YES } \\
\text { YES }\end{array}$ & $\begin{array}{l}\text { S13 } \\
\text { S13 }\end{array}$ & $\begin{array}{r}9 \\
309\end{array}$ & $\begin{array}{r}65 \\
331\end{array}$ \\
\hline
\end{tabular}

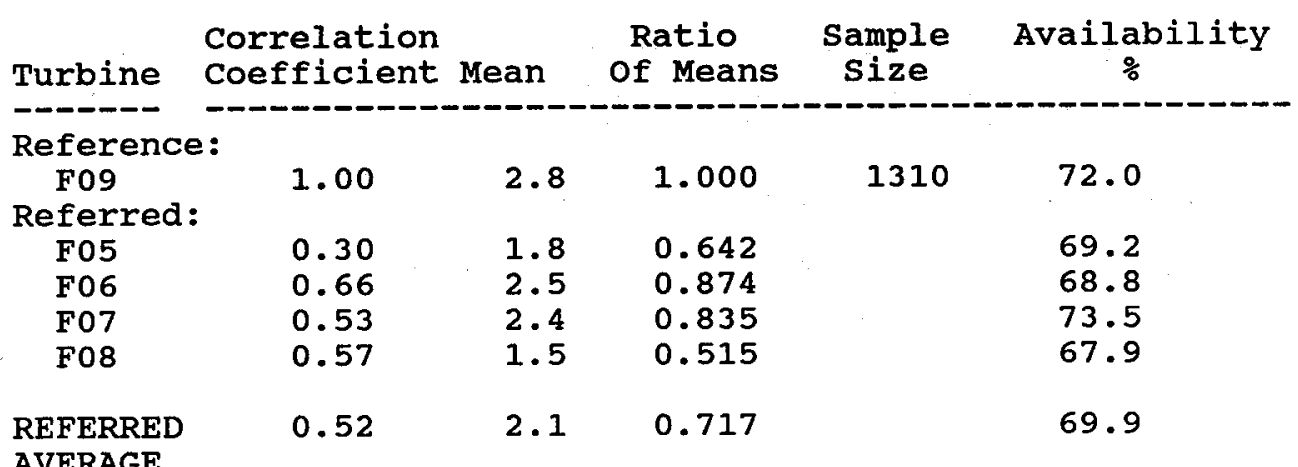

Note: F10 was not included due to low availability.

Table 3-7.2hh Souza F9 row, -22 degrees

\begin{tabular}{lrrrr}
$\begin{array}{l}\text { Screen } \\
\text { Enabled }\end{array}$ & $\begin{array}{c}\text { Screening } \\
\text { Turbine }\end{array}$ & $\begin{array}{c}\text { Minimum } \\
\text { (from) }\end{array}$ & $\begin{array}{c}\text { Maximum } \\
\text { (to) }\end{array}$ & Units \\
\hline YES & S13 & 9 & 65 & mph \\
YES & S13 & 287 & 309 & deg.
\end{tabular}

Screen by Speed:

Screen by Direction:

Ratio Sample

Turbine Coefficient Mean of Means Size

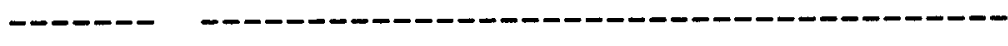

Reference:

$\begin{array}{lllll}\text { F09 } & 1.00 & 1.5 & 1.000 & 227\end{array}$

Referred:

F05 $\quad 0.63 \quad 1.5 \quad 1.036$

$\begin{array}{llll}\text { F06 } & 0.77 & 1.1 & 0.756\end{array}$

$\begin{array}{llll}\text { F07 } & 0.72 & 1.6 & 1.074\end{array}$

F08 $\quad 0.71 \quad 1.2 \quad 0.810$

$\begin{array}{llll}\text { REFERRED } & 0.71 & 1.4 & 0.919\end{array}$

AVERAGE 
Table 3-7.2ii Souza F9 row, +22 degrees

WINDFARM CORRELATION REPORT

REPORT INTERVAL: WINTER 87-88 Correlation Variable:

ENERGY

Reference Turbine: $\quad$ F09

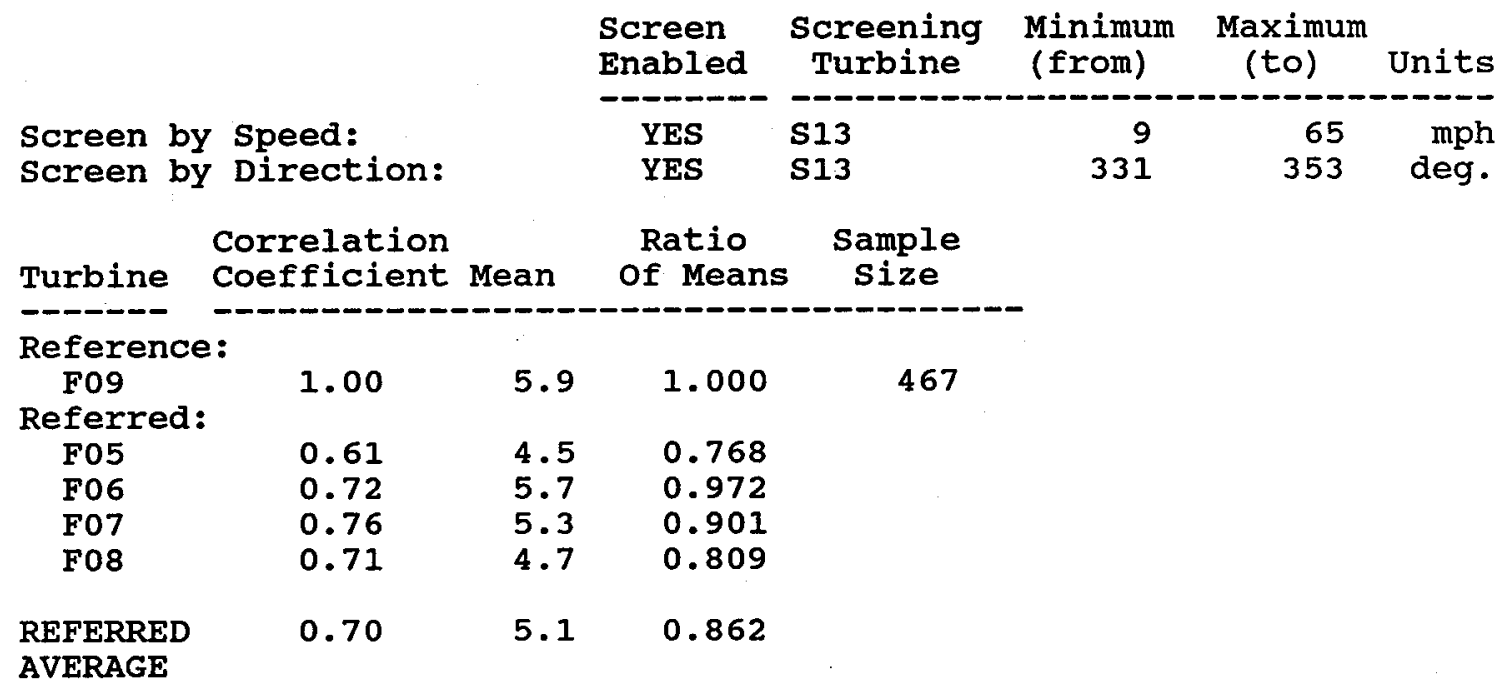

Table 3-7.2jj Souza F9 row, low winds

Screen by speed:

\begin{tabular}{lrrrr}
$\begin{array}{l}\text { Screen } \\
\text { Enabled }\end{array}$ & $\begin{array}{c}\text { Screening } \\
\text { Turbine }\end{array}$ & $\begin{array}{c}\text { Minimum } \\
\text { (from) }\end{array}$ & $\begin{array}{c}\text { Maximum } \\
\text { (to) }\end{array}$ & Units \\
\hline YES & S13 & 9 & 25 & mph \\
YES & S13 & 309 & 331 & deg.
\end{tabular}

Screen by Direction:

Turbine $\begin{array}{lcc}\text { Correlation } & \text { Ratio } & \text { Sample } \\ \text { Coefficient Mean of Means } & \text { Size }\end{array}$

Reference: - -

Reference:

F09

1.00

2.0

1.000

1021

Referred:

F05

0.38

0.52

06

0.33

1.4

0.739

F07

0.38

1.7

0.747

F08

0.40

0.7

0.874

REFERRED

1. 3

0.359

AVERAGE 
Table 3-7.2kk Souza F9 row, moderate winds

WINDFARM CORRELATION REPORT

REPORT INTERVAL: WINTER 87-88 Correlation Variable: ENERGY Reference Turbine: F09

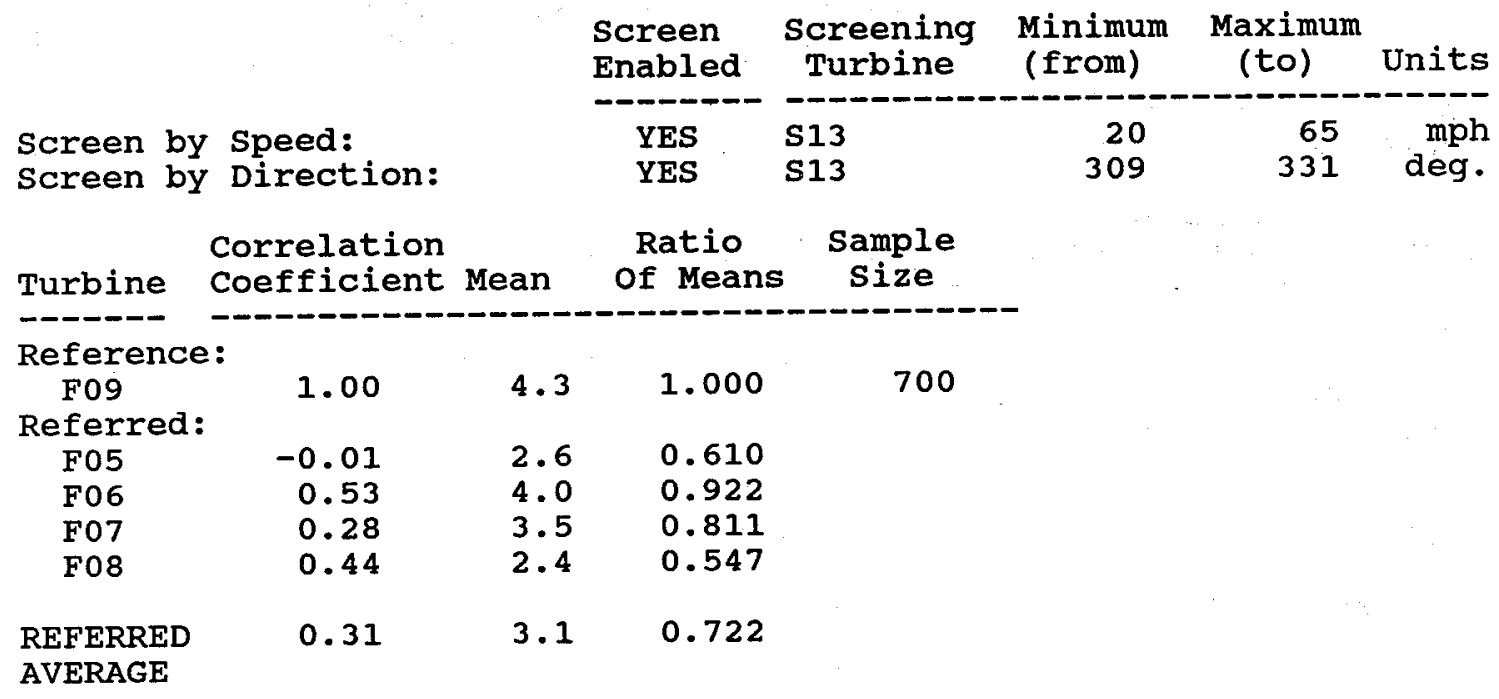

Table 3-7.211 Souza F9 row, high winds

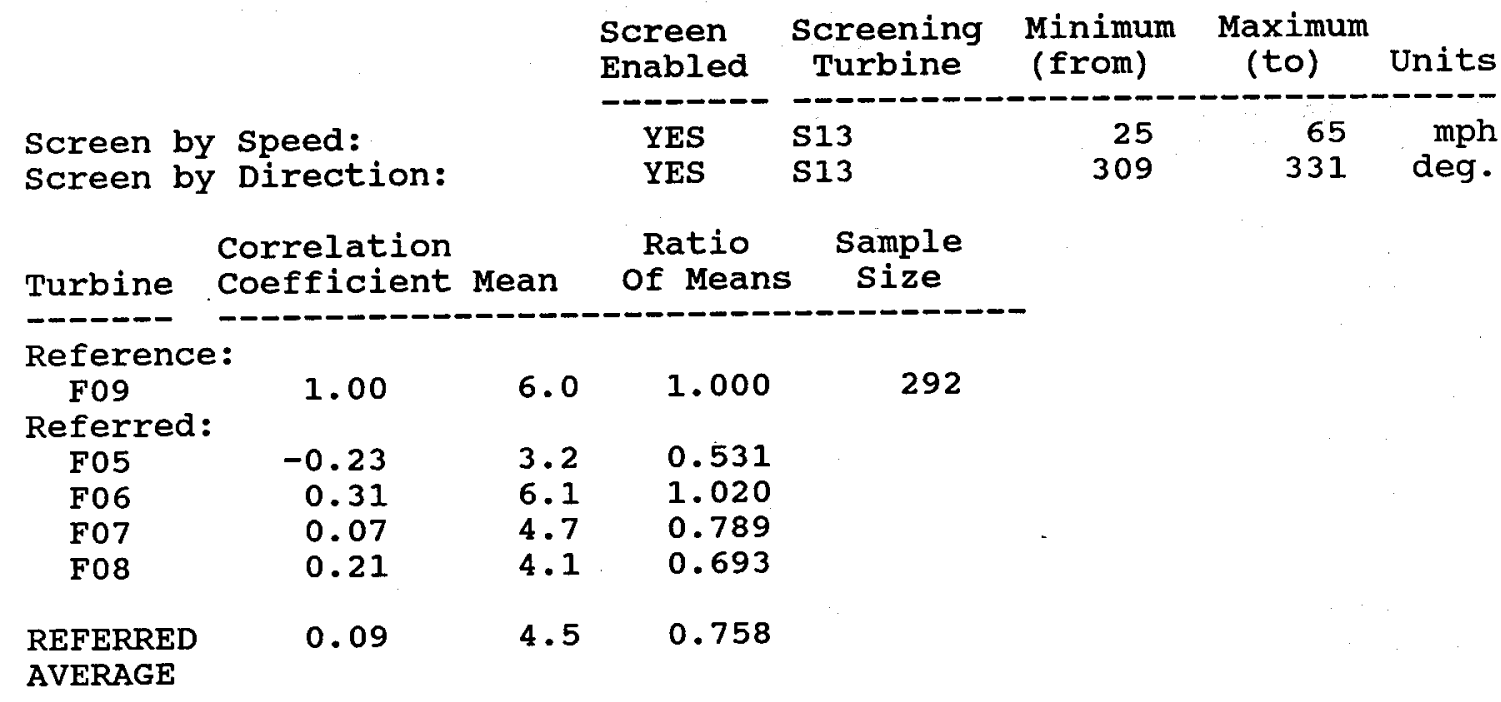


Table 3-7.2mm Souza F9 row, daylight hours

WINDFARM CORRELATION REPORT

REPORT INTERVAL: WINTER 87-88 Correlation Variable: ENERGY

Reference Turbine: $\quad$ F09

\begin{tabular}{|c|c|c|c|c|c|c|}
\hline & & $\begin{array}{l}\text { Screen } \\
\text { Enabled }\end{array}$ & $\begin{array}{l}\text { Screening } \\
\text { Turbine }\end{array}$ & $\begin{array}{l}\text { Minimum } \\
\text { (from) }\end{array}$ & $\begin{array}{l}\text { Maximum } \\
\text { (to) }\end{array}$ & Unit \\
\hline Screen by & Speed: & YES & S13 & 9 & 65 & \\
\hline Screen by & Direction: & YES & S13 & 309 & 331 & \\
\hline Screen by & Time: & YES & --- & $08: 00$ & $17: 00$ & \\
\hline
\end{tabular}

\begin{tabular}{lcccc} 
Turbine & $\begin{array}{l}\text { Correlation } \\
\text { Coefficient }\end{array}$ Mean & $\begin{array}{c}\text { Ratio } \\
\text { Of Means }\end{array}$ & $\begin{array}{c}\text { Sample } \\
\text { Size }\end{array}$ \\
\hline $\begin{array}{l}\text { Reference: } \\
\text { F09 }\end{array}$ & 1.00 & 3.2 & 1.000 & 293 \\
$\begin{array}{l}\text { Referred: } \\
\text { F05 }\end{array}$ & 0.53 & 2.7 & 0.841 & \\
F06 & 0.71 & 3.7 & 1.160 & \\
F07 & 0.58 & 3.2 & 1.017 & \\
F08 & 0.58 & 2.4 & 0.744 & \\
REFERRED & 0.60 & 3.0 & 0.940 & \\
AVERAGE & & &
\end{tabular}

Table 3-7.2nn Souza F9 row, nightime hours

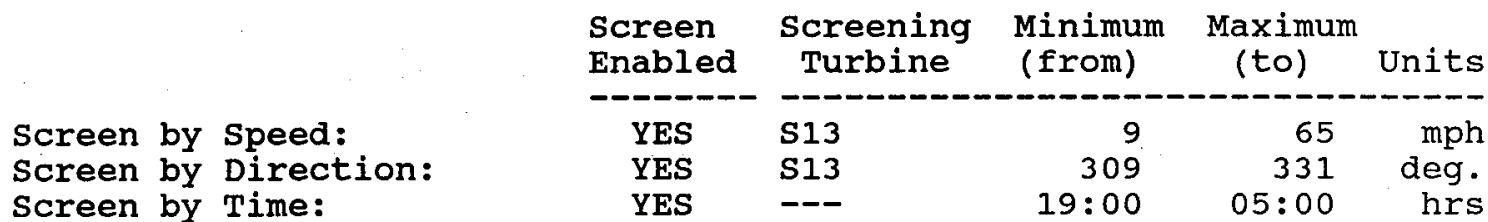

$\begin{array}{lll} & \text { Correlation } & \text { Ratio Sample } \\ \text { Turbine } & \text { Coefficient Mean Of Means Size }\end{array}$

$\begin{array}{llll}\begin{array}{l}\text { Reference: } \\ \text { F09 }\end{array} & 1.00 & 2.6 & 1.000 \\ \begin{array}{l}\text { Referred: } \\ \text { F05 }\end{array} & 0.10 & 1.5 & 0.583 \\ \text { F06 } & 0.68 & 1.9 & 0.717 \\ \text { F07 } & 0.54 & 2.0 & 0.769 \\ \text { F08 } & 0.58 & 1.1 & 0.420 \\ \text { REFERRED } & 0.48 & 1.6 & 0.622 \\ \text { AVERAGE } & & & \end{array}$


Table 3-7.3a Jess L13 row, parallel winds

WINDFARM CORRELATION REPORT

REPORT INTERVAL: WINTER 87-88 Correlation Variable: ENERGY

Reference Turbine: $\quad$ L13

\begin{tabular}{|c|c|c|c|c|}
\hline & $\begin{array}{l}\text { Screen } \\
\text { Enabled }\end{array}$ & $\begin{array}{l}\text { Screening } \\
\text { Turbine }\end{array}$ & $\begin{array}{l}\text { Minimum } \\
\text { (from) }\end{array}$ & $\begin{array}{l}\text { Maximum } \\
\text { (to) }\end{array}$ \\
\hline $\begin{array}{l}\text { Screen by Speed: } \\
\text { Screen by Direction: }\end{array}$ & $\begin{array}{l}\text { YES } \\
\text { YES }\end{array}$ & $\begin{array}{l}\text { J08 } \\
\text { J08 }\end{array}$ & $\begin{array}{r}9 \\
322\end{array}$ & $\begin{array}{r}65 \\
344\end{array}$ \\
\hline
\end{tabular}

$\begin{array}{lccccc}\text { Turbine } & \begin{array}{c}\text { Correlation } \\ \text { Coefficient }\end{array} & \text { Mean } & \begin{array}{c}\text { Ratio } \\ \text { Of Means }\end{array} & \begin{array}{c}\text { Sample } \\ \text { Size }\end{array} & \begin{array}{c}\text { Availability } \\ \text { \% }\end{array} \\ \begin{array}{l}\text { Reference: } \\ \text { L13 }\end{array} & 1.00 & 3.4 & 1.000 & 538 & 94.8 \\ \begin{array}{l}\text { Referred: } \\ \text { L07 }\end{array} & 0.58 & 1.6 & 0.469 & 535^{\circ} & 78.9 \\ \text { L08 } & 0.94 & 2.9 & 0.867 & 535 & 95.9 \\ \text { L10 } & 0.91 & 2.9 & 0.865 & 537 & 75.0 \\ \text { L11 } & 0.80 & 2.1 & 0.610 & 537 & 75.0 \\ \text { L12 } & 0.92 & 2.6 & 0.751 & 533 & 92.6 \\ & & & & & 83.5\end{array}$

AVERAGE

Note: L09 was not included due to low availability.

Table 3-7.3b Jess L13 row, -22 degrees

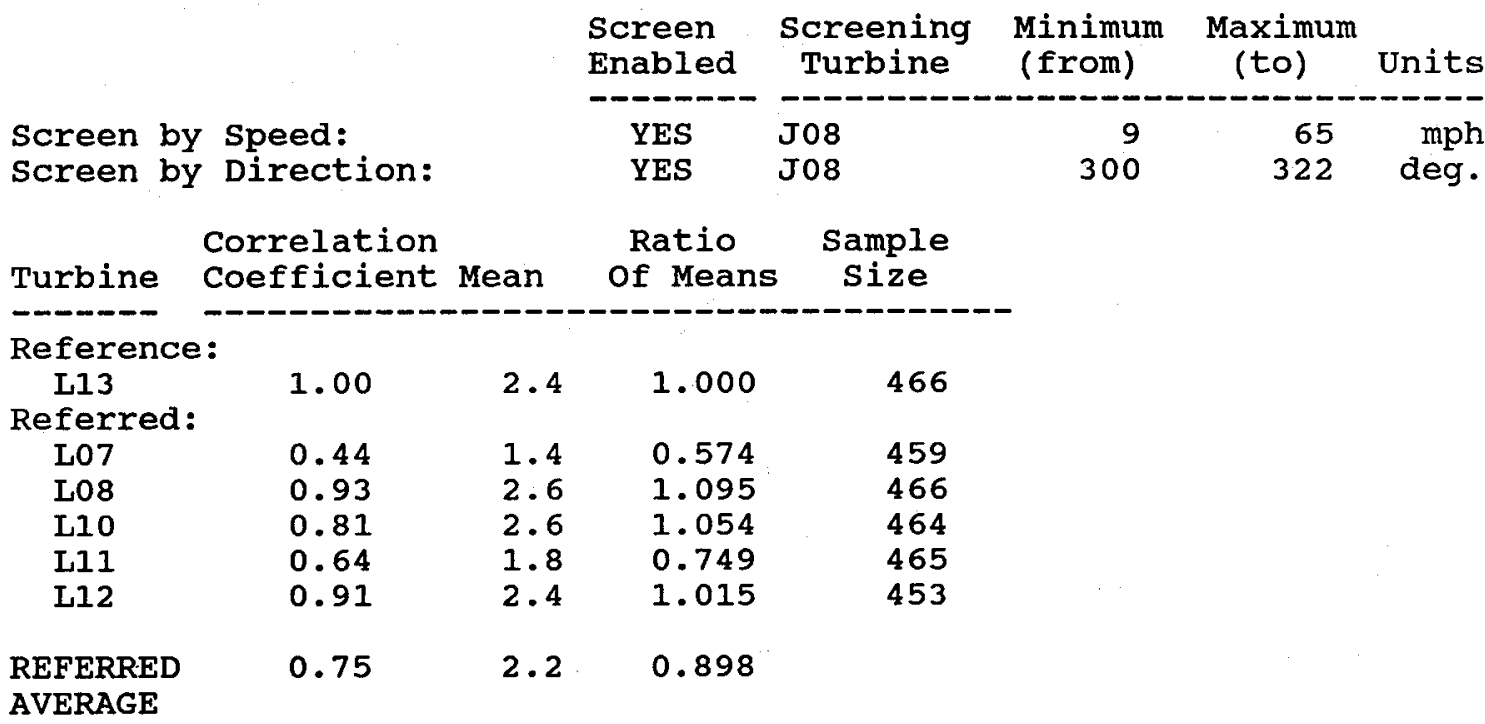


Table 3-7.3c Jess Ll3 row, +22 degrees

WINDFARM CORRELATION REPORT

REPORT INTERVAL: WINTER 87-88 Correlation Variable: ENERGY

Reference Turbine: $\quad$ L13

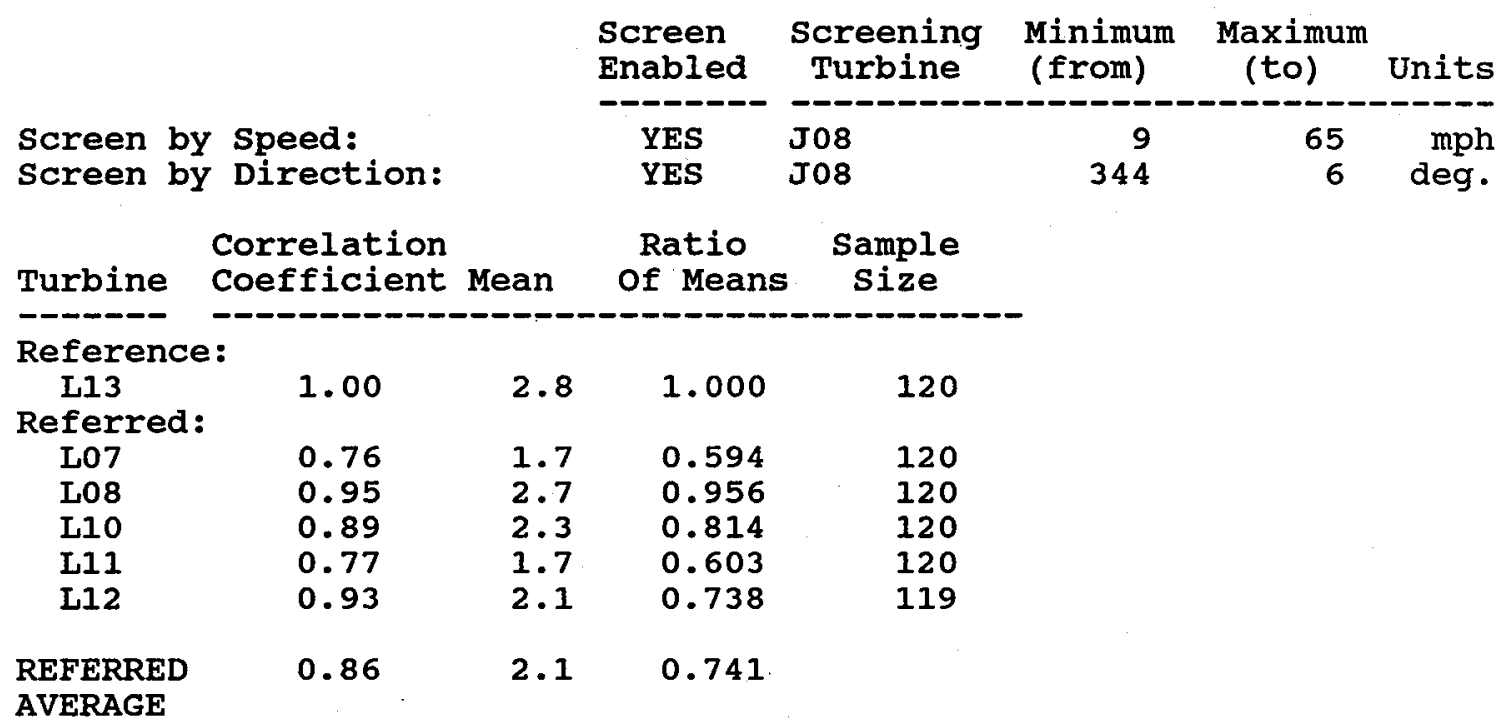


Table 3-7.3d Jess M08 row, parallel winds

WINDFARM CORRELATION REPORT

REPORT INTERVAL: WINTER 87-88 Correlation Variable: ENERGY

Reference Turbine: M08

\begin{tabular}{lcrrrr} 
& $\begin{array}{c}\text { Screen } \\
\text { Enabled }\end{array}$ & $\begin{array}{c}\text { Screening } \\
\text { Turbine }\end{array}$ & $\begin{array}{l}\text { Minimum } \\
\text { (from) }\end{array}$ & $\begin{array}{r}\text { Maximum } \\
\text { (to) }\end{array}$ & Units \\
\hline Screen by Speed: & YES & J08 & 9 & 65 & mph \\
Screen by Direction: & YES & J08 & 322 & 344 & deg.
\end{tabular}

Screen by Direction:

Ratio Sample Availability

\begin{tabular}{cccccr} 
Turbine & $\begin{array}{c}\text { Correlation } \\
\text { Coefficient }\end{array}$ & Mean & $\begin{array}{c}\text { Ratio } \\
\text { of Means }\end{array}$ & $\begin{array}{c}\text { Sample } \\
\text { Size }\end{array}$ & $\begin{array}{r}\text { Availab } \\
\%\end{array}$ \\
\hline $\begin{array}{l}\text { Reference: } \\
\text { M08 }\end{array}$ & 1.00 & 4.4 & 1.000 & 499 & 74.9 \\
$\begin{array}{l}\text { Referred: } \\
\text { M01 }\end{array}$ & 0.83 & 1.6 & 0.361 & 499 & 91.7 \\
M02 & 0.94 & 3.3 & 0.748 & 498 & 93.7 \\
M03 & 0.87 & 2.2 & 0.492 & 499 & 95.6 \\
M04 & 0.87 & 2.1 & 0.472 & 499 & 90.9 \\
M05 & 0.55 & 1.2 & 0.282 & 499 & 74.2 \\
M06 & 0.86 & 2.2 & 0.504 & 499 & 94.0 \\
M07 & 0.78 & 2.0 & 0.452 & 499 & 80.3
\end{tabular}

$\begin{array}{lllll}\text { REFERRED } & 0.81 & 2.1 & 0.473 & 88.6\end{array}$

AVERAGE

Table 3-7.3e Jess M08 row, -22 degrees

\begin{tabular}{lcrrrr} 
& $\begin{array}{l}\text { Screen } \\
\text { Enabled }\end{array}$ & $\begin{array}{l}\text { Screening } \\
\text { Turbine }\end{array}$ & $\begin{array}{l}\text { Minimum } \\
\text { (from) }\end{array}$ & \multicolumn{1}{c}{$\begin{array}{c}\text { Maximum } \\
\text { (to) }\end{array}$} & Units \\
\hline Screen by Speed: & YES & J08 & 9 & 65 & mph \\
Screen by Direction: & YES & J08 & 300 & 322 & deg.
\end{tabular}

\begin{tabular}{cccc} 
Turbine & $\begin{array}{l}\text { Correlation } \\
\text { Coefficient Mean }\end{array}$ & $\begin{array}{c}\text { Ratio } \\
\text { Of Mean }\end{array}$ \\
\hline $\begin{array}{c}\text { Reference: } \\
\text { M08 }\end{array}$ & 1.00 & 3.1 & 1.000 \\
Referred: & & & \\
M01 & 0.89 & 1.4 & 0.460 \\
M02 & 0.96 & 2.7 & 0.855 \\
M03 & 0.92 & 1.8 & 0.583 \\
M04 & 0.85 & 1.6 & 0.500 \\
M05 & 0.58 & 1.0 & 0.310 \\
M06 & 0.91 & 2.1 & 0.662 \\
M07 & 0.57 & 1.1 & 0.344
\end{tabular}

$\begin{array}{llll}\text { REFERRED } & 0.81 & 1.7 & 0.531\end{array}$

AVERAGE 
Table 3-7.3f Jess M08 row, +22 degrees

WINDFARM CORRELATION REPORT

REPORT INTERVAL: WINTER 87-88 Correlation Variable: ENERGY

Reference Turbine: M08

$\begin{array}{lcrrrr} & \begin{array}{l}\text { Screen } \\ \text { Enabled }\end{array} & \begin{array}{c}\text { Screening } \\ \text { Turbine }\end{array} & \begin{array}{l}\text { Minimum } \\ \text { (from) }\end{array} & \begin{array}{c}\text { Maximum } \\ \text { (to) }\end{array} & \text { Units } \\ \text { Screen by Speed: } & \text { YES } & \text { J08 } & 9 & 65 & \mathrm{mph} \\ \text { Screen by Direction: } & \text { YES } & \text { J08 } & 344 & 6 & \text { deg. }\end{array}$

\begin{tabular}{cccc} 
Turbine & $\begin{array}{l}\text { Correlation } \\
\text { Coefficient Mean }\end{array}$ & $\begin{array}{c}\text { Ratio } \\
\text { of Means }\end{array}$ \\
\hline $\begin{array}{l}\text { Reference: } \\
\text { M08 }\end{array}$ & 1.00 & 4.3 & 1.000 \\
$\begin{array}{l}\text { Referred: } \\
\text { M01 }\end{array}$ & 0.86 & 1.7 & 0.388 \\
M02 & 0.96 & 3.4 & 0.788 \\
M03 & 0.91 & 2.4 & 0.549 \\
M04 & 0.93 & 2.3 & 0.541 \\
M05 & 0.66 & 1.5 & 0.355 \\
M06 & 0.90 & 2.5 & 0.572 \\
M07 & 0.80 & 2.2 & 0.499
\end{tabular}

$\begin{array}{llll}\text { REFERRED } & 0.86 & 2.3 & 0.527\end{array}$

AVERAGE

Table 3-7.3g Jess M08 row, low winds

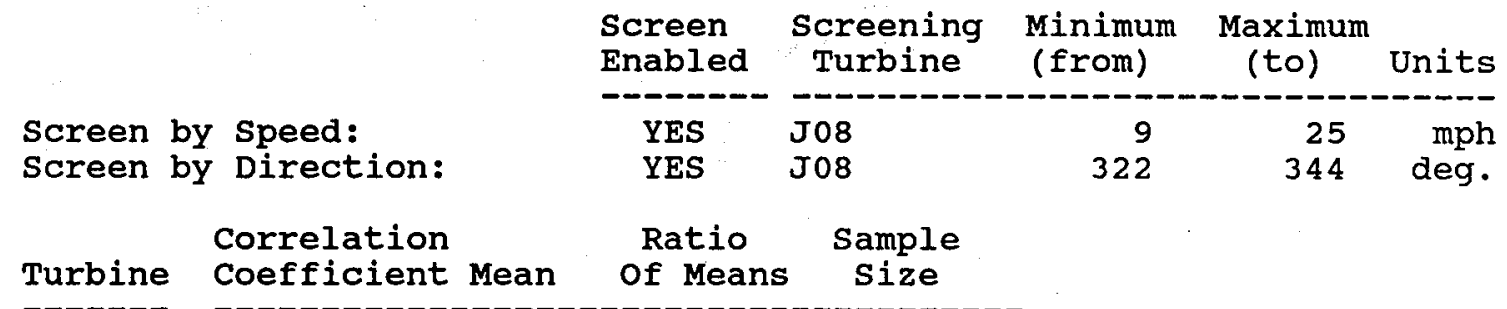

Reference:

M08

Referred:

MO1

M02

M03

M04

M05

M06

M07

REFERRED

AVERAGE
1.00

3.7

1.000

1.1

0.297

0.80

0.92

0.83

0.84

0.36

0.82

0.72

2.6

1.6

0.684

1.6

0.427

0.8

0.420

1.7

0.211

1.4

0.448

0.364

0.76

1.5

0.407 
Table 3-7.3h Jess M08 row, moderate winds

WINDFARM CORRELATION REPORT

REPORT INTERVAL: WINTER 87-88 Correlation Variable: ENERGY

Reference Turbine: M08

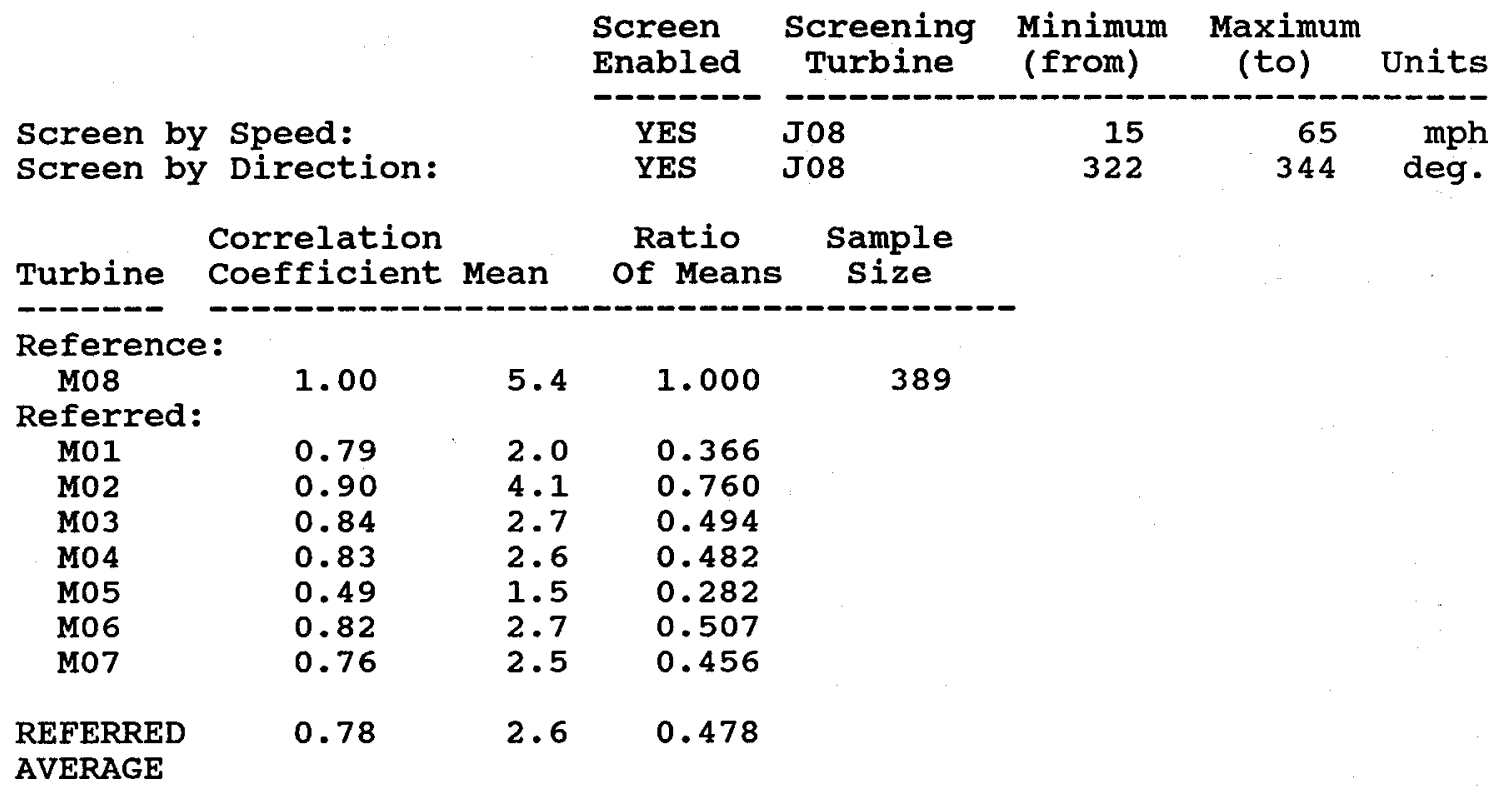

Table 3-7.3i Jess M08 row, high winds

\begin{tabular}{|c|c|c|c|c|c|c|c|}
\hline & & & $\begin{array}{l}\text { Screen } \\
\text { Enabled }\end{array}$ & $\begin{array}{l}\text { Screening } \\
\text { Turbine }\end{array}$ & $\begin{array}{l}\text { Minimum } \\
\text { (from) }\end{array}$ & $\begin{array}{l}\text { Maximum } \\
\text { (to) }\end{array}$ & Units \\
\hline $\begin{array}{l}\text { Screen by } \\
\text { Screen by }\end{array}$ & $\begin{array}{l}\text { Speed: } \\
\text { Direction: }\end{array}$ & & $\begin{array}{l}\text { YES } \\
\text { YES }\end{array}$ & $\begin{array}{l}\text { J08 } \\
\text { J08 }\end{array}$ & $\begin{array}{r}25 \\
322\end{array}$ & $\begin{array}{r}65 \\
344\end{array}$ & $\begin{array}{l}\text { mph } \\
\text { deg. }\end{array}$ \\
\hline Turbine & $\begin{array}{l}\text { Correlation } \\
\text { Coefficient }\end{array}$ & Mean & $\begin{array}{l}\text { Ratio } \\
\text { of Means }\end{array}$ & $\begin{array}{c}\text { Sample } \\
\text { Size }\end{array}$ & & & \\
\hline Reference & & & & & & & \\
\hline $\begin{array}{l}\text { M08 } \\
\text { Referred: }\end{array}$ & 1.00 & 8.0 & 1.000 & 118 & & & \\
\hline M01 & 0.86 & 4.3 & 0.541 & & & & \\
\hline MO2 & 0.93 & 7.3 & 0.902 & & & & \\
\hline M03 & 0.91 & 5.4 & 0.676 & & & & \\
\hline M04 & 0.89 & 5.2 & 0.646 & & & & \\
\hline M05 & -0.24 & 2.7 & 0.337 & & & & \\
\hline M06 & 0.89 & 5.4 & 0.671 & & & & \\
\hline M07 & 0.86 & 5.6 & 0.704 & & & & \\
\hline $\begin{array}{l}\text { REFERRED } \\
\text { AVERAGE }\end{array}$ & 0.73 & 5.1 & 0.639 & & & & \\
\hline
\end{tabular}


Table 3-7.3j Jess M08 row, daylight hours

WINDFARM CORRELATION REPORT

REPORT INTERVAL: WINTER 87-88 Correlation Variable: ENERGY

Reference Turbine: M08

$\begin{array}{lcrrrr} & \begin{array}{c}\text { Screen } \\ \text { Enabled }\end{array} & \begin{array}{c}\text { Screening } \\ \text { Turbine }\end{array} & \begin{array}{c}\text { Minimum } \\ \text { (from) }\end{array} & \begin{array}{c}\text { Maximum } \\ \text { (to) }\end{array} \\ & \text { Units } \\ \text { Screen by Speed: } & \text { YES } & \text { J08 } & 9 & 65 & \text { mph } \\ \text { Screen by Direction: } & \text { YES } & \text { J08 } & 322 & 344 & \text { deg. } \\ \text { Screen by Time: } & \text { YES } & --- & 08: 00 & 17: 00 & \text { hrs }\end{array}$

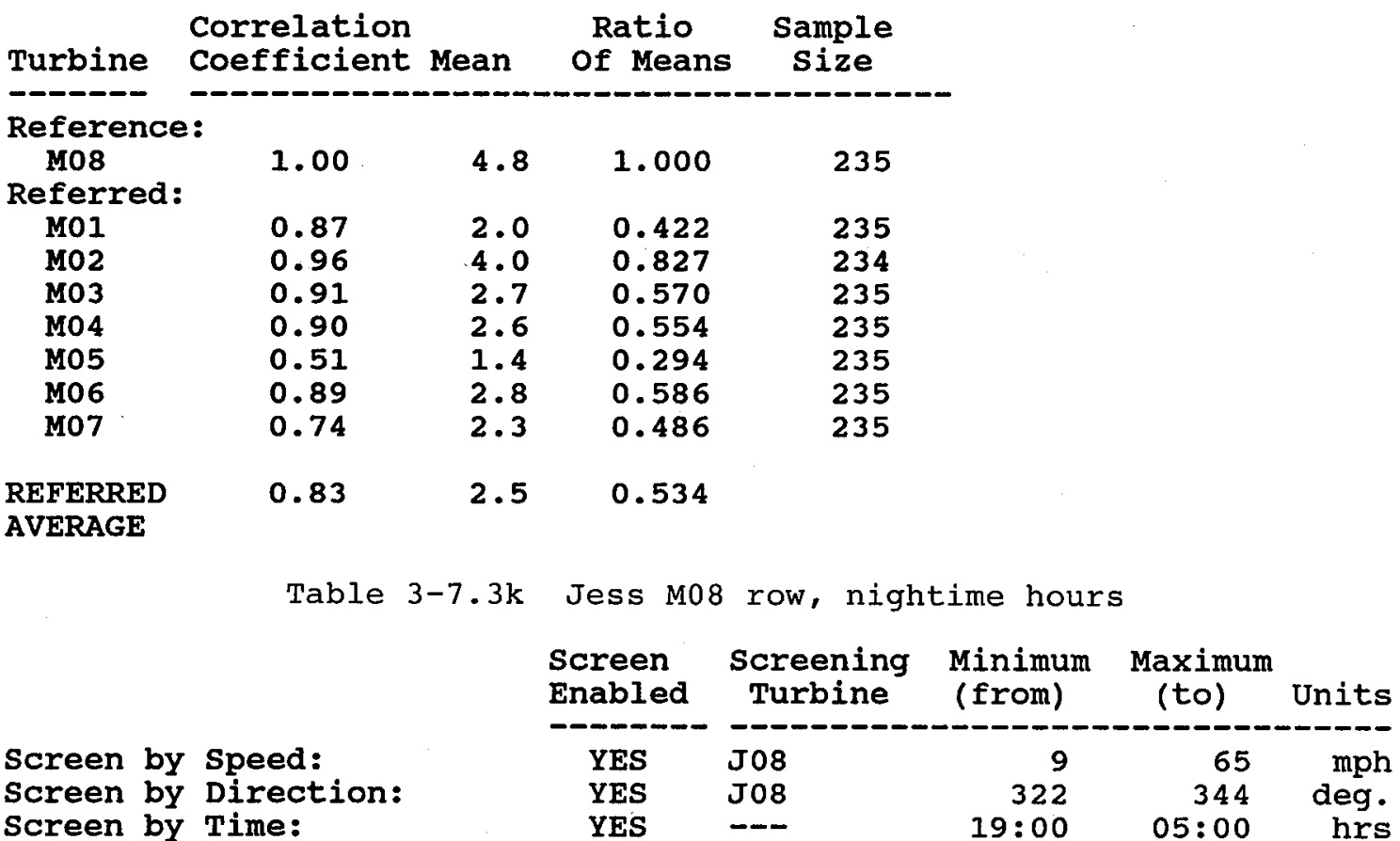

\begin{tabular}{llll} 
Turbine & $\begin{array}{l}\text { Correlation } \\
\text { Coefficient }\end{array}$ & \multicolumn{1}{c}{$\begin{array}{c}\text { Ratio } \\
\text { Of Means }\end{array}$} \\
\hline $\begin{array}{l}\text { Reference: } \\
\text { M08 }\end{array}$ & 1.00 & 4.0 & 1.000 \\
Referred: & & & \\
M01 & 0.79 & 1.2 & 0.297 \\
M02 & 0.92 & 2.7 & 0.659 \\
M03 & 0.85 & 1.7 & 0.409 \\
M04 & 0.90 & 1.5 & 0.383 \\
M05 & 0.62 & 1.1 & 0.273 \\
M06 & 0.86 & 1.7 & 0.419 \\
M07 & 0.84 & 1.6 & 0.401
\end{tabular}

$\begin{array}{llll}\text { REFERRED } & 0.83 & 1.6 & 0.406\end{array}$


Table 3-7.31 Jess M13 row, parallel winds

WINDFARM CORRELATION REPORT

REPORT INTERVAL: WINTER 87-88 correlation Variable: ENERGY Reference Turbine: M13

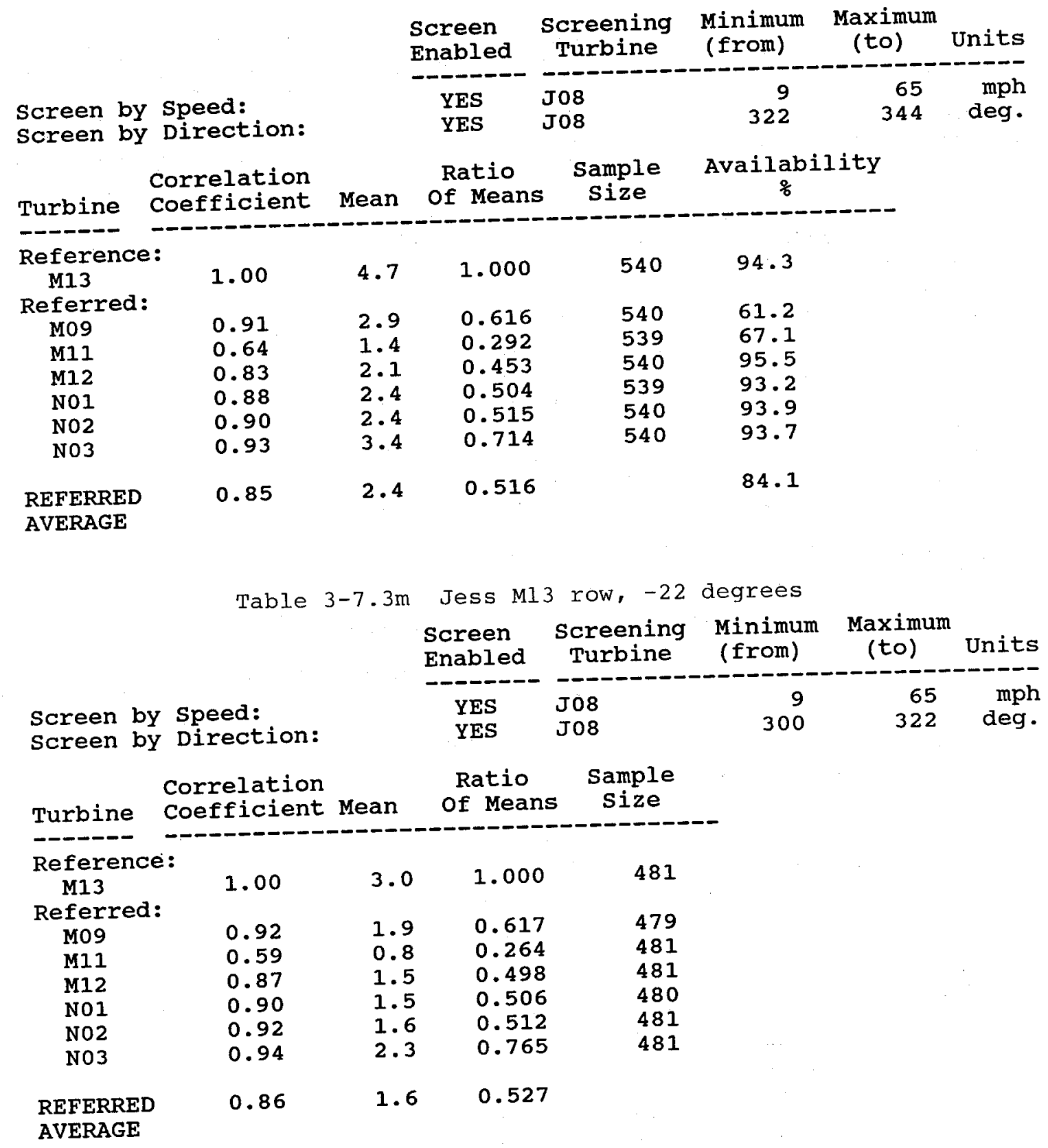


Table $3-7.3 \mathrm{n}$ Jess M13 row, +22 degrees

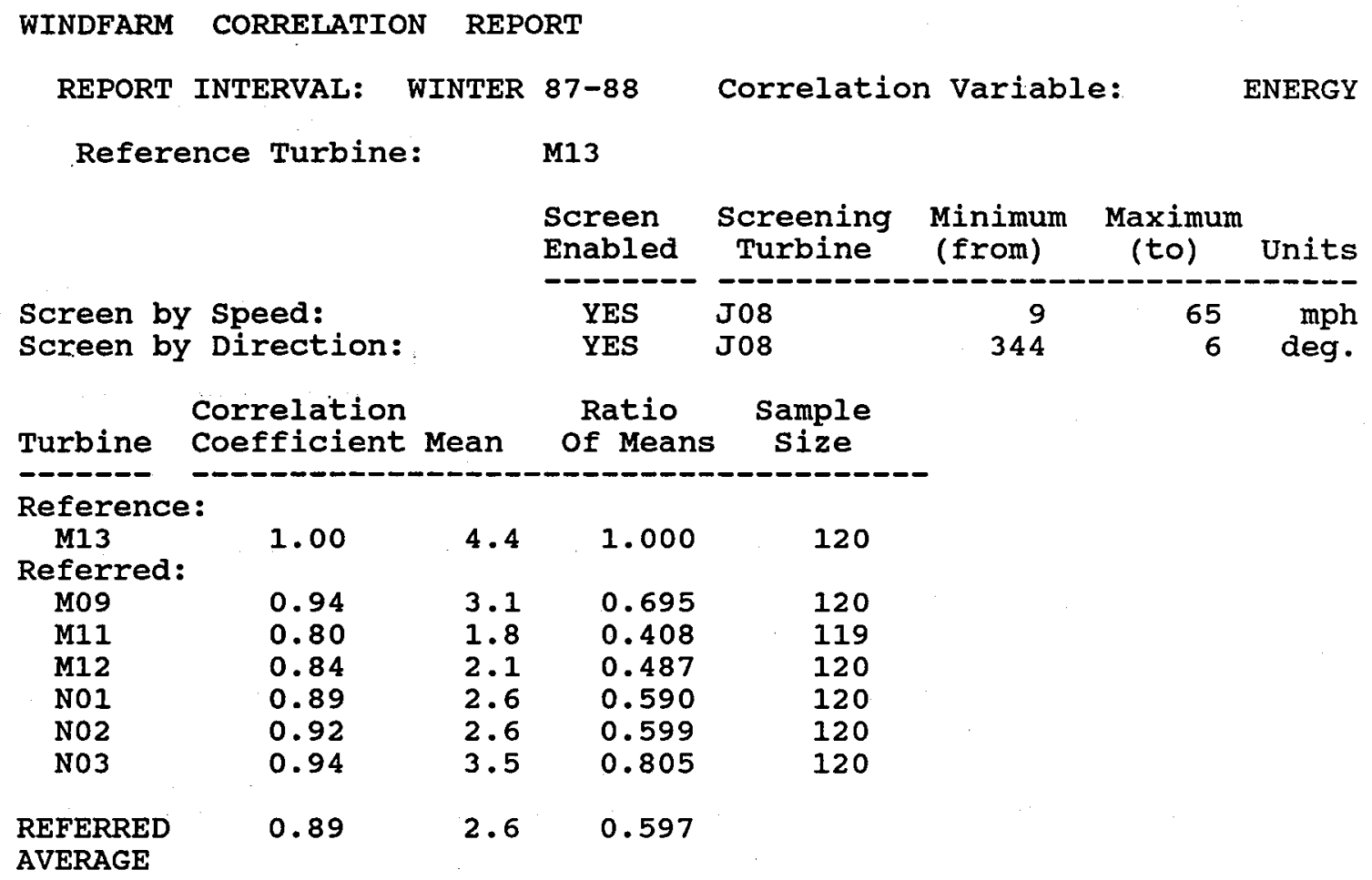




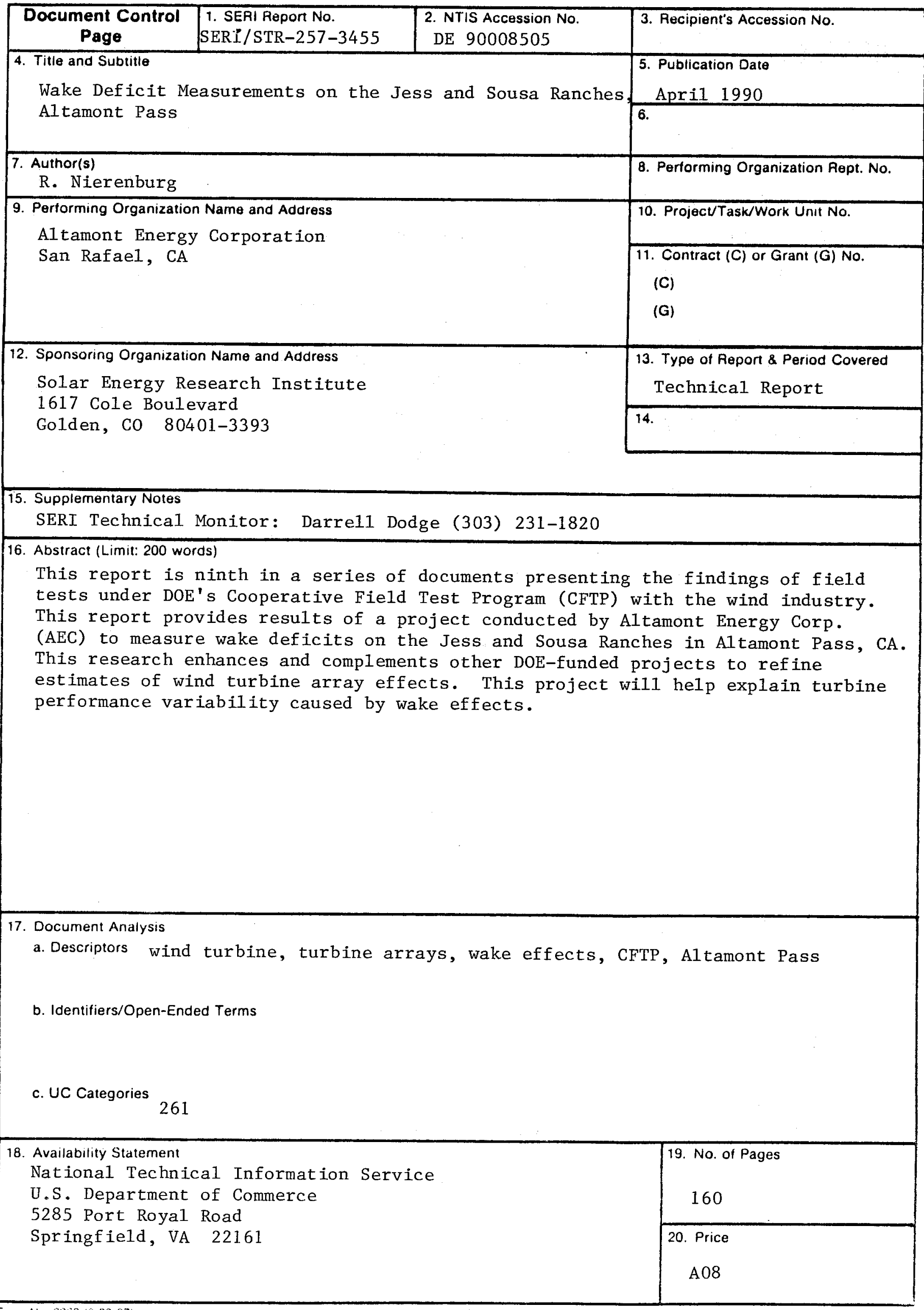

